\author{
by \\ Maudud Hassan Quazi \\ Bachelor of Engineering (Mechanical) \\ Ryerson University \\ Toronto, Canada, 2007

\begin{abstract}
A MRP
presented to Ryerson University

in partial fulfillment of the

requirements for the degree of

Master of Engineering in the program of
\end{abstract} \\ Mechanical and Industrial Engineering
}

Toronto, Ontario, Canada 2016

C(Maudud Hassan Quazi) 2016 
I hereby declare that I am the sole author of this MRP. This is a true copy of the MRP, including any required final revisions, as accepted by my examiners.

I authorize Ryerson University to lend this MRP to other institutions or individuals for the purpose of scholarly research.

I further authorize Ryerson University to reproduce this MRP by photocopying or by other means, in total or in part, at the request of other institutions or individuals for the purpose of scholarly research.

I understand that my MRP may be made electronically available to the public. 


\title{
DESIGN AND ANALYSIS OF A DISTRIBUTED WATER HEAT PUMP SYSTEM FOR \\ NEAR- AND NET-ZERO ENERGY COMMERCIAL BUILDINGS
}

\author{
Master of Engineering (Mechanical), 2016 \\ Maudud Hassan Quazi \\ Ryerson University
}

\begin{abstract}
This objective of this project is to determine the energy and environmental potential of distributed common loop water source heat pump system in a near or net-zero commercial office building, which has simultaneous heating and cooling load in winter and shoulder seasons. It is expected that the perimeter zones will have heating demand during those months, while the core zones will have consistent cooling demand throughout the year. The motive is to reclaim the rejected heat from the cooling operation and transfer it to the zones requiring heating. The building under study is a $60,000 \mathrm{ft}^{2}$ three storey commercial office building, which has private offices along the perimeter, and open work area in the core.
\end{abstract}

In the first part of the analysis, the base building has been modelled and simulated to the minimum requirements of ASHRAE 90.1-Energy Standard for Buildings except Low-Rise Residential Buildings using simulation software eQuest 3.65. The Heating Ventilation and Airconditioning (HVAC) system used is four-pipe fan coil system serving individual zones. The fan coil units use a centralized natural gas boiler and a variable capacity centrifugal chiller as external source of heating and cooling respectively. The base case consumes a total of $524.54 \mathrm{x}$ $1000 \mathrm{kWh}$ of electricity and 1,056 million Btu of natural gas annually.

The second part is the modelling and simulation of a proposed case, which uses the same building envelope, occupancy, lighting and equipment as the base case. The HVAC system used is a distributed common loop heat pump system connected to a cooling tower for heat rejection, and a condensing boiler for heat addition. During the occupied hours, when simultaneous cooling and heating loads exist in the building, the cooling zone heat pumps rejects exhaust heat into the common loop, and the heat is subsequently used by the heat pumps operating in heating mode. Using this method, the heat pump system reduces its dependence on the cooling tower and the boiler, which only operate to maintain the loop temperature in an acceptable range. 
There is $9,510 \mathrm{kWh}(1.81 \%)$ increase in electricity consumption by proposed case comparing to the base building. Natural gas consumption has been reduced by 353.65 million Btu (33.48\%). Annual utility bill has increased by $\$ 1,483.00$ which is $1.88 \%$ higher than the base case. 15.7 tonnes of greenhouse gas can be reduced if the proposed case is adopted. 


\section{Acknowledgements}

First of all, I would like to humble myself to my Creator, who has given me the ability to learn.

I would like to thank Dr. Alan Fung for being my advisor and for providing his valuable guidance for this project. I would also like to thank Dr. Wey Leong for serving on the examination committee.

I would like to recognize the tireless support of my parents and siblings for my education and the sacrifices of my wife and son during my master's study. 


\section{Table of Contents}

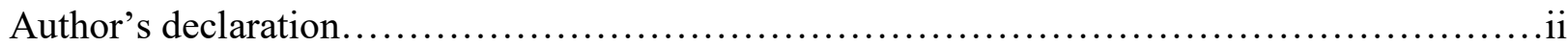

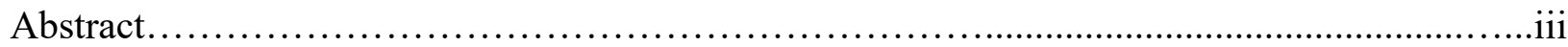

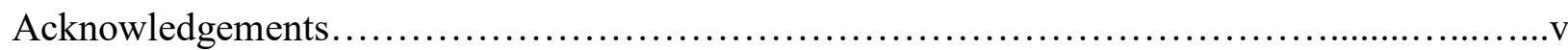

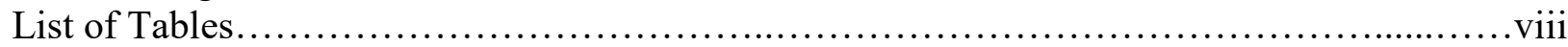

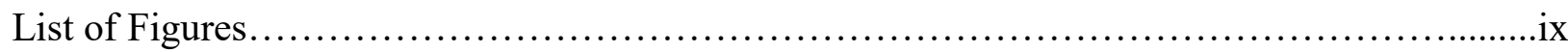

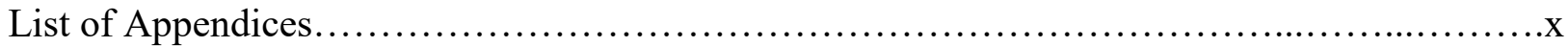

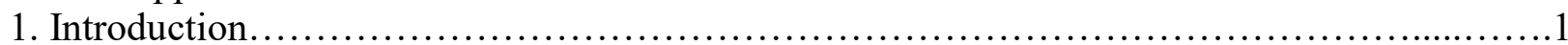

1.1 Purpose of the project........................................................

1.2 Energy use of commercial buildings in Canada....................................

1.3 Commercial building heating and cooling load characteristics....................4

1.4 Heating ventilation and air conditioning (HVAC) system........................

1.5 Heat pump technology and its working principal..................................

1.6 Energy efficiency requirement for internal closed loop heat pumps.................15

1.7 AHRAE 90.1 Standard......................................................... 15

1.8 eQuest building simulation tool...............................................

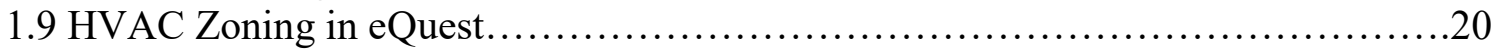

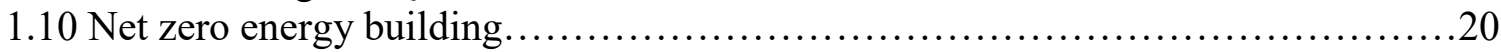

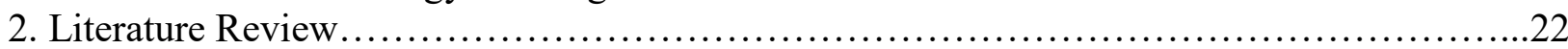

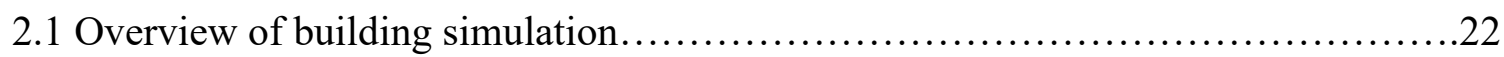

2.2 Building envelope design for energy balance.................................. 25

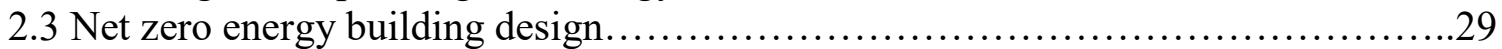

2.4 Effect of building aspect ratio on energy efficiency............................. 34

2.5 Design of typical water source heat pump systems............................. 35

2.5.1 Daikin McQuay Inc. design guide for heat pumps........................35

2.5.2 Thermal performance of heat pumps...............................42

2.5.3 Effect of heat pump operating conditions.............................43

2.6 Energy conservation using water source heat pumps...........................45

2.7 Optimizing water loop temperature ....................................... 47

2.8 Case study: Office building heat recovery using heat pumps.....................47

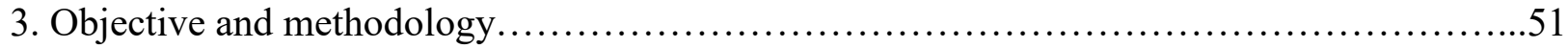

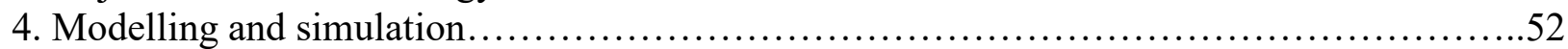

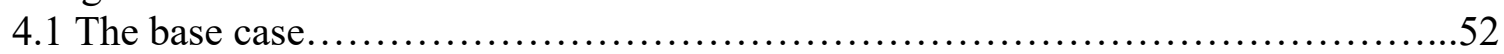

4.1.1 Base case simulation results........................................62

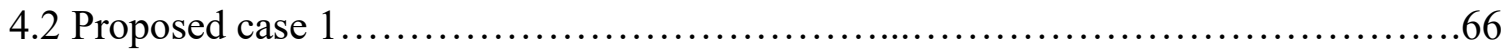

4.3 Result comparison........................................................ 71

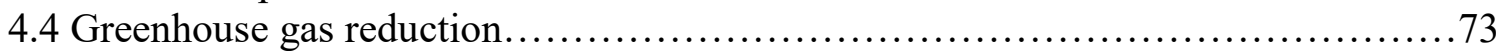

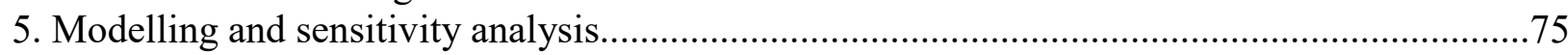

5.1 Sensitivity analysis for finding optimum operating temperature of the loop.............75

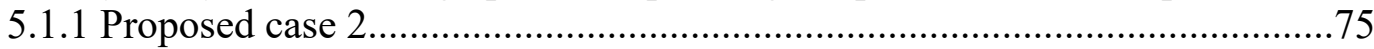

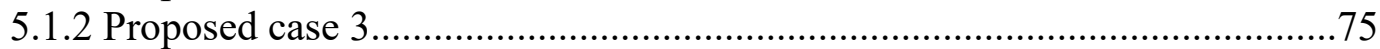

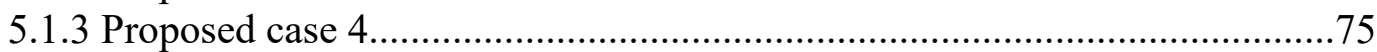

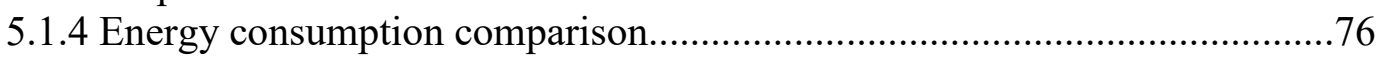

5.2 Comparison between the base case and optimum proposed case............................... 76

6. Conclusion. 


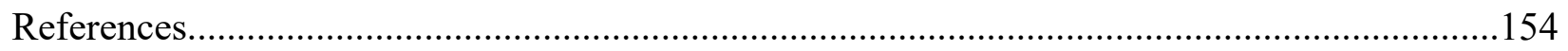




\section{List of Tables}

Table 1: Building characteristics and energy use by primary activity....................................6

Table 2: Daikin McQuay water source heat pump performance............................................12

Table 3. ClimateMaster water source heat pump performance..............................................13

Table 4: Trance Inc. Water source heat pump performance......................................................14

Table 5: Minimum COP requirements for internal loop heat pumps (NRCan).........................15

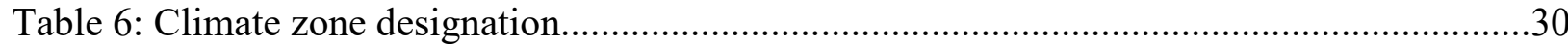

Table 7: Aspect ratio for simulation geometry (McKeen \& Fung)..........................................34

Table 8: Annual energy consumption for different aspect ratio (McKeen \& Fung)....................35

Table 9: Cooling COP of water source heat pump in variant condition (Zheng \& Jing).............44

Table 10: Heating COP of water source heat pump in variant condition (Zheng \& Jing)...........44

Table 11: Modelling parameters of the commercial office building for case study (Rao \&

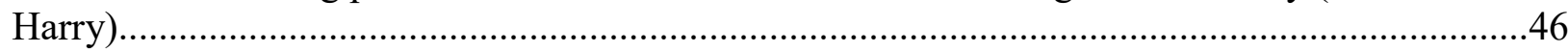

Base building design parameters:

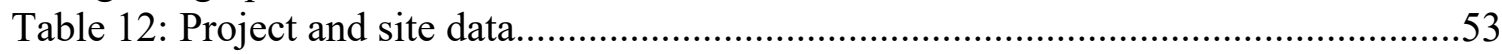

Table 13: Electricity time of use (TOU) rate for summer...........................................53

Table 13A: Electricity time of use (TOU) rate for winter..........................54

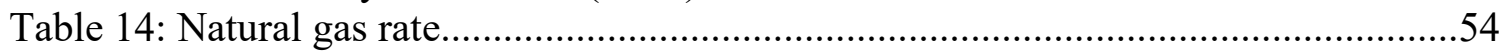

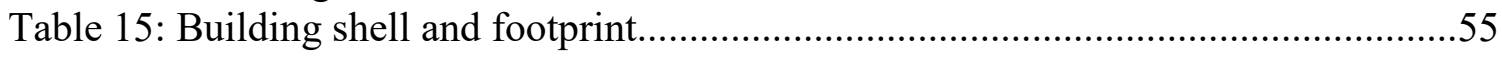

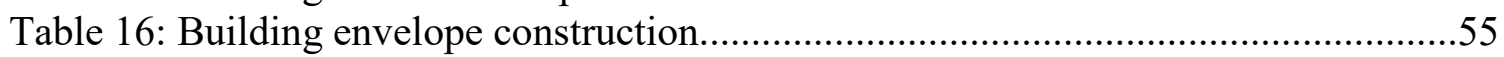

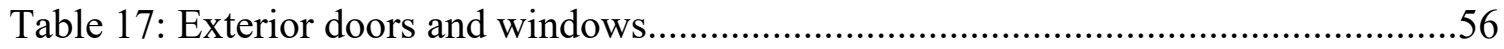

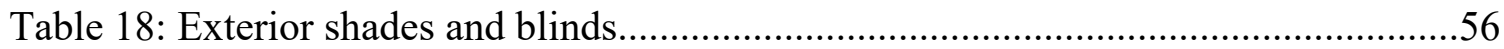

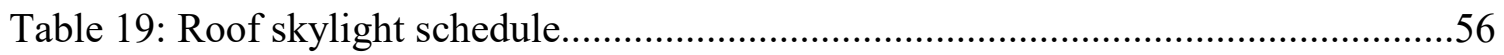

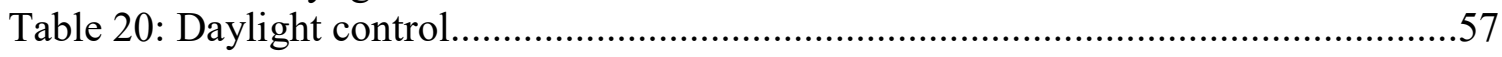

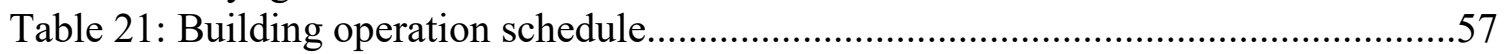

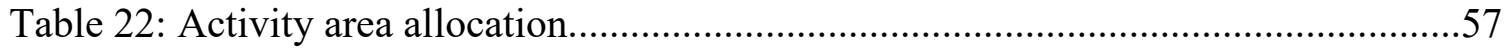

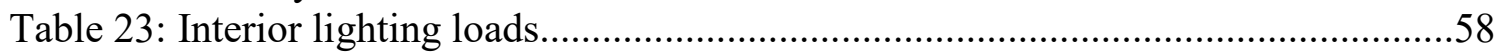

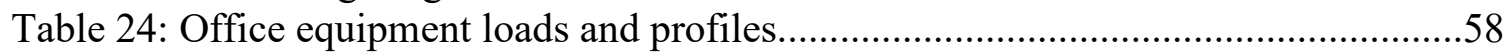

Table 25: Zone HVAC system parameters.................................................................59

Table 26: Cooling primary equipment design parameters.............................................59

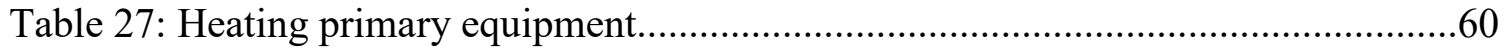

Table 28: Domestic hot water modelling parameters....................................................60

Table 29: Base building peak load components (eQuest simulation result)..............................63

Table 30: Base building zone peak heating and cooling loads (eQuest simulation result)..........64

Table 31: Base building monthly and annual electricity consumption......................................65

Table 32: Base building monthly and annual gas consumption..............................................66

Table 33: Proposed case 1 zone HVAC system parameters....................................................67

Table 34: Proposed case 1 water source heat pump..............................................................6

Table 35: Proposed case 1 monthly and annual electricity consumption.................................69

Table 36: Proposed case 1 monthly and annual natural gas consumption.................................... 70

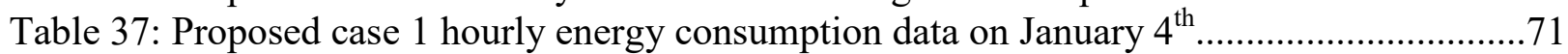

Table 38: Base case vs proposed case 1 electricity consumption comparison.............................72

Table 39: Base case vs proposed case 1 natural gas consumption..............................................73

Table 40: Sensitivity test to optimize heat pump water loop temperature.................................76

Table 41: Energy and economic comparison between the base and the optimum proposed case.77 


\section{List of Figures}

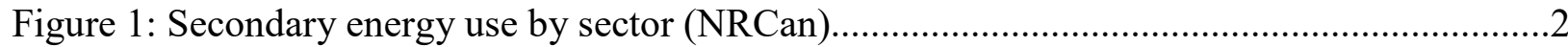

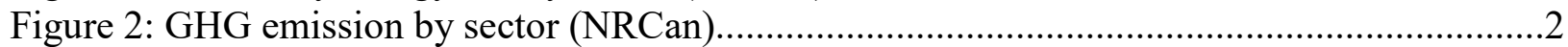

Figure 3: Commercial/institutional floor space by activity type in 2009 (NRCan)......................3

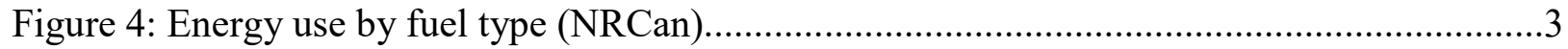

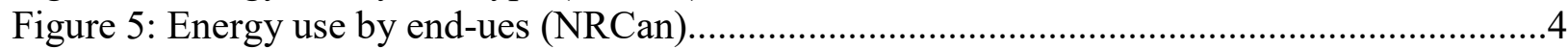

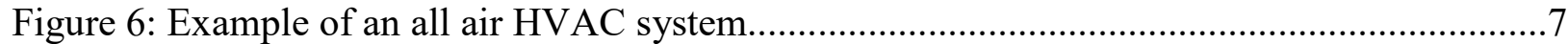

Figure 7: Example of water-to-air HVAC system........................................................

Figure 8: Example of a building air system designed in eQuest...............................................9

Figure 9: Heat pump cycle based on vapour compression................................................ 10

Figure 10: Example of a 3D building model generated by eQuest..........................................19

Figure 11: Energy transfer between a building and its surrounding (Chwieduk)......................29

Figure 12: Annual energy use intensity of commercial buildings in different zones based on average of 16 commercial building type (Hootman) ......................................................... 31

Figure 13: Commercial/institutional building energy intensity by activity type (NRCan)..........32

Figure 14: Configuration of conventional water-source heat pump system for cooling only

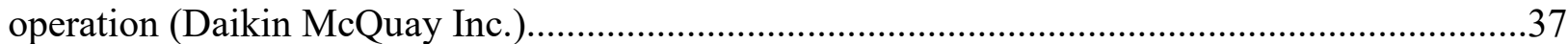

Figure 15: Configuration of conventional water-source heat pump system for mainly heating

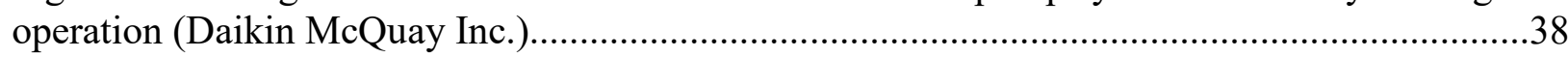
Figure 16: Configuration of conventional water-source heat pump system in buildings with high

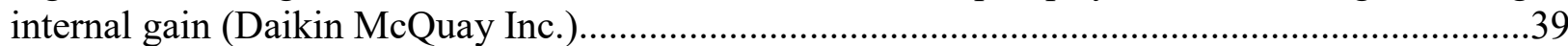

Figure 17: Configuration of conventional water-source heat pump system for simultaneous cooling and heating load (Daikin McQuay Inc.).................................................................40

Figure 18: Heat pump system with heat storage (Daikin McQuay Inc.)..................................41

Figure 19: Source temperature at supply and return sides of the heat pump (Liu, Qu, Ge).........43

Figure 20: Schematic for ventilation heating and cooling system of a building using heat pump heat recovery system.

Figure 21: Modelled vs actual energy consumption of a building using heat pump heat recovery

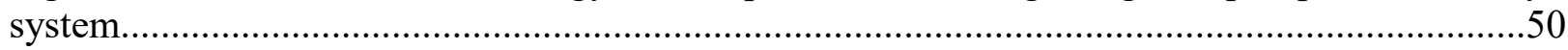

Figure 22: 3D view of the three storey office building for the base case.................................61

Figure 23: Schematic of heating, cooling and domestic hot water for the base building.............62

Figure 24: Common loop water source heat pump schematic for the proposed case...................68 


\section{List of Appendices}

Appendix 1: Conceptual design of common loop water source heat pump with heat storage......79 Appendix 2: Typical office floor layout with water source heat pumps....................................81 Appendix 3: Building load from eQuest simulation........................................................83 


\section{Introduction}

\subsection{Purpose of the Project}

The purpose of this project is to examine energy saving potential of an office building located in Toronto by modelling it to ASHRAE 90.1 standard and using distributed water loop heat pump (DWLHP) system for providing simultaneous heating and cooling in different zones. Toronto has a large number of commercial buildings used for variety of different industries. Often the office buildings have cooling load in the core zones during the winter season because of heat generated from occupancy, lighting and other office equipment. Buildings also lose heat to the ambient during the winter because of the difference between the indoor design temperature and the outdoor temperature. Thus addition of heating energy is required to maintain the indoor comfort condition. A common loop water source heat pump is a system, where some heat pumps extract heat from the water loop and add thermodynamic work in order to release higher amount of heat to the space; on the other hand heat pumps in cooling mode extract heat from the space and perform thermodynamic work to reject more heat to the water loop. It is also known that normally the offices are occupied for a certain period of time during the day, and unoccupied for the remaining hours. During the unoccupied hours of winter, interior heat generation does not take place. Therefore, to eliminate the role of external heat generating equipment, the cumulative daily heat rejection to the common water loop must exceed the cumulative daily heat extracted.

\subsection{Energy Use of Commercial Buildings}

According to a Natural Resources Canada publication titled Energy Efficiency Trends in Canada 1990 to 2009, floor space for the entire commercial/institutional sector is equivalent to about 40 percent of the total residential floor space. In 2009, the commercial/institutional sector was responsible for 14 percent of the total energy use in Canada and produced 13 percent of the associated greenhouse gas (GHG) emissions, shown in Figure 1 and Figure 2 (NRCan, 2011). 


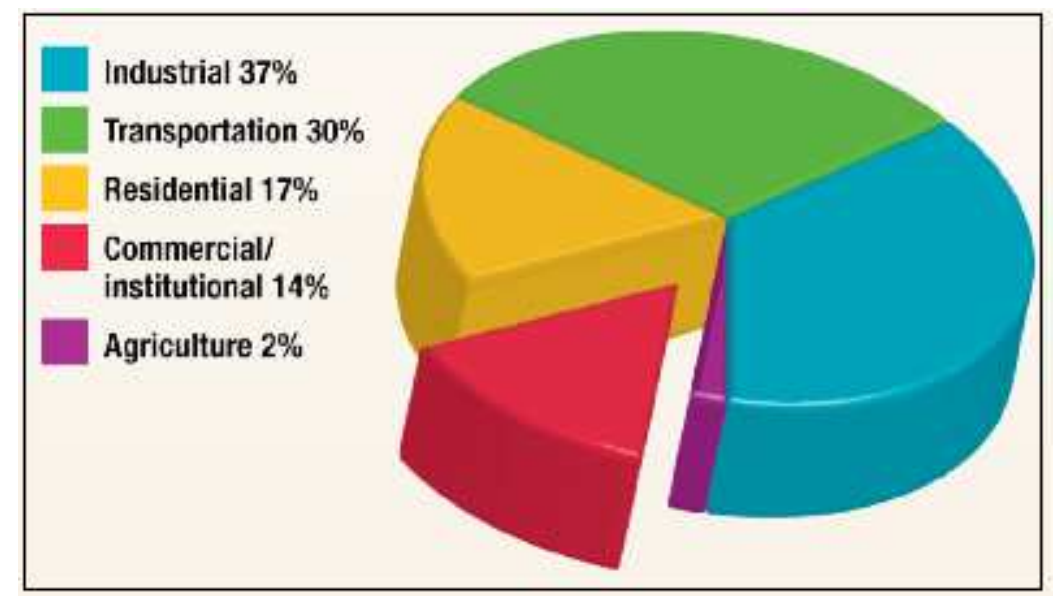

Figure 1: Secondary energy use by sector (NRCan, 2011)

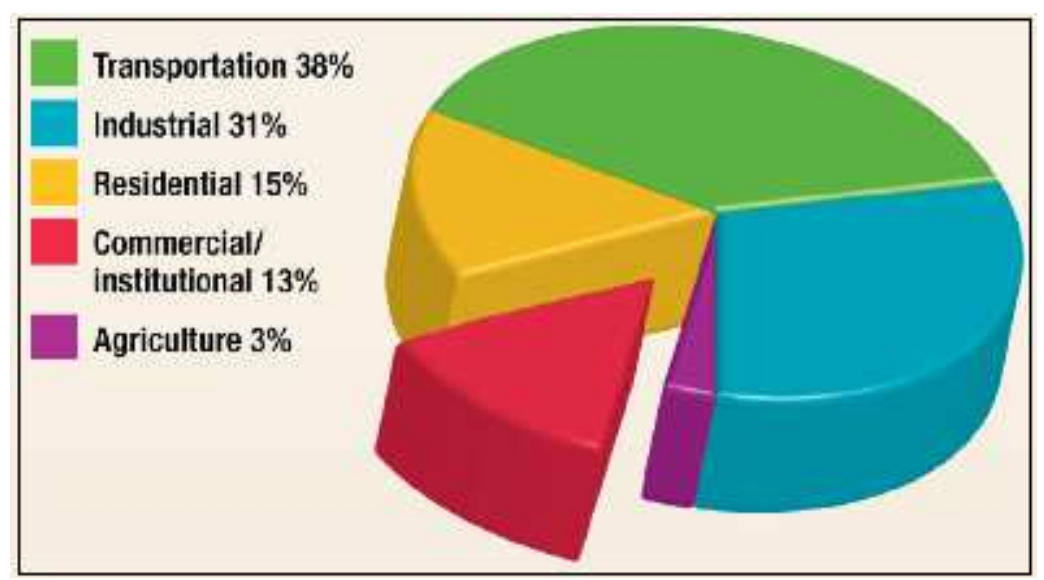

Figure 2: GHG emission by sector (NRCan, 2011)

Space heating accounts for the largest share of energy use. Figure 3 shows that in the commercial sector offices, retail trade and educational services account for 70 percent of the total Canadian commercial/institutional floor space, which in 2009 was estimated at 709.5 million $\mathrm{m}^{2}$ (NRCan, 2011). 


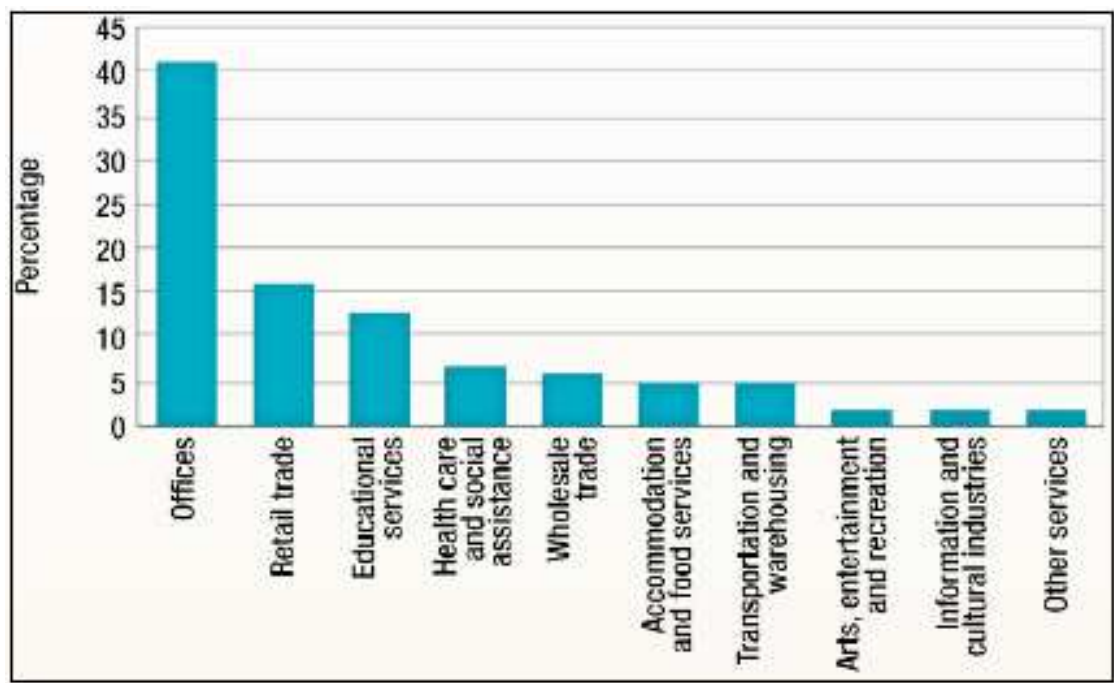

Figure 3: Commercial/institutional floor space by activity type in 2009 (NRCan, 2011)

Natural gas and electricity are the main energy source for the commercial/industrial sector, accounting for 87 percent of the energy use. According to Figure 4 and Figure 5, electricity is the primary source of energy for lighting, space cooling, auxiliary motors and equipment. Natural gas and the remaining fuels are the primary energy sources for space and water heating (NRCan, 2011).

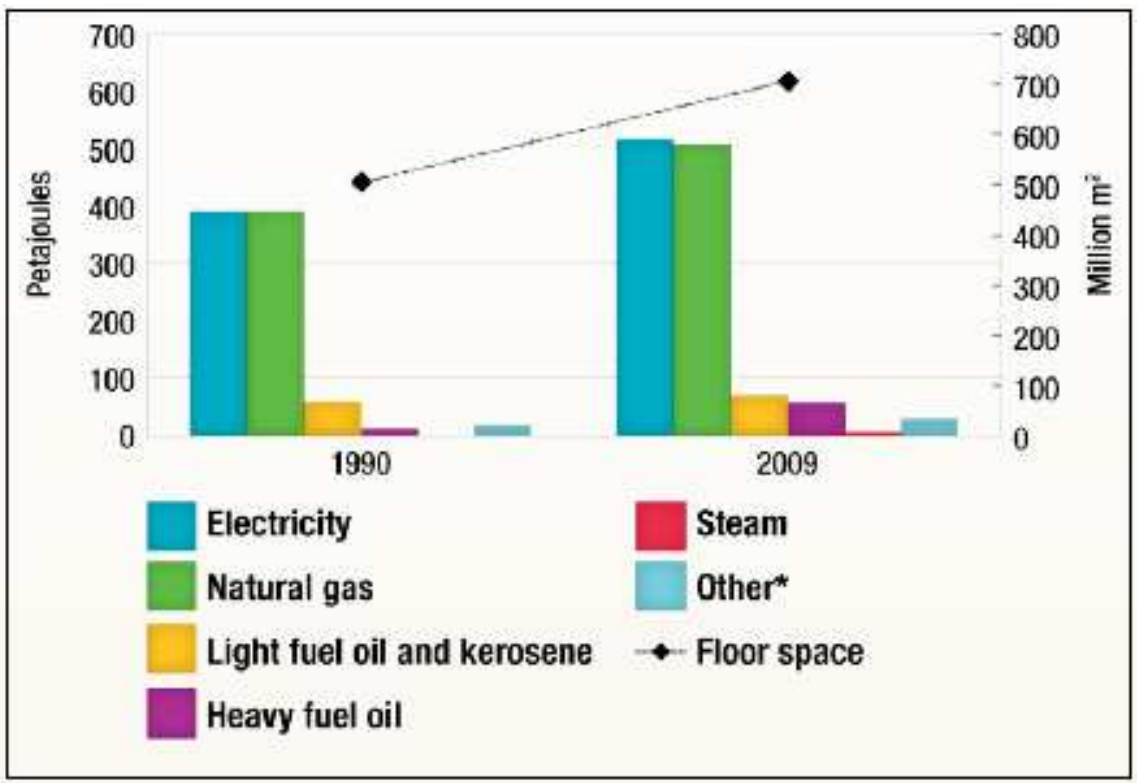

Figure 4: Energy use by fuel type (NRCan, 2011) 


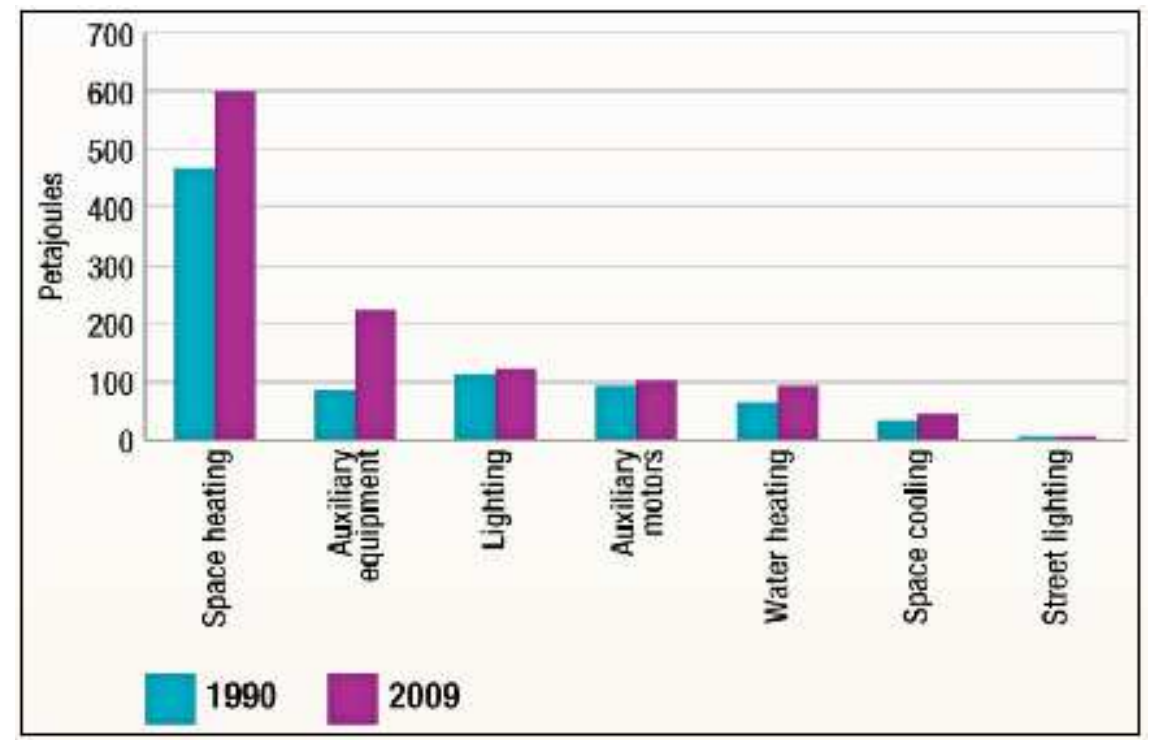

Figure 5: Energy use by end-use (NRCan, 2011)

\subsection{Commercial Building heating and cooling load characteristics}

Office buildings are of two types; those that are occupied by the owner for company head office or local business, and the ones that are built for leasing to tenants. In both cases a safe and comfortable working condition takes the utmost priority. A comfortable indoor working condition is vital to the performance of the workers and thus, a design must take in consideration all necessary factors. Few important environmental requirements for comfortable working conditions are temperature, humidity, air movement, noise, cleanliness. The factors that affect the environmental requirements are: climate conditions: local temperature, humidity, wind speed, day and night length, rain, snow etc.

Building Physical Characteristics include:

- Building envelope such as wall, floor, roof, windows, doors and framing.

- Orientation and aspect ratio of the building.

- Reflectance and solar heat gain through the windows and doors.

- Heat loss/heat gain and humidity transfer through infiltration dependent upon the air tightness of the building envelope.

- Internal sources such as lighting, office equipment, motors etc. 
Enclosed space require fresh air supply, which is required to be heated, cooled, humidified and de-humidified based on design conditions.

Density of population adds to the heating/cooling load of the building in two ways. Human body produces heat, thus higher occupancy density adds more heat to the indoor environment, and increases requirement for cooling while decreases heating requirement. Higher occupancy also requires increased outdoor air, which need to be conditioned before introducing to the indoor environment. Activities of the occupant also contribute to the heating and cooling load. Walking or physical activities generate more heat than sedentary activities.

This project analyzes and optimizes aspects of building design, which contributes to the heating and cooling load as well as energy consumption. These factors will be discussed in details in the forthcoming sections.

While building envelope design and internal factors influence heating and cooling load in the interior space, building HVAC system provide the heating, cooling, humidification and dehumidification for maintaining indoor comfort condition. The perception of comfort, temperature and thermal acceptability is related to one's rate of metabolic heat production, its rate of transfer to the environment, and the resulting physiological adjustments and body temperatures. The heat transfer rate from the body is influenced by the environmental factors of air temperature, thermal radiation, air movement, and humidity, and by the personal factors of activity and clothing. The temperature range for comfort in summer is higher than for winter. The acceptable range of operative temperature for winter and summer is $73-75^{\circ} \mathrm{F}\left(23-24^{\circ} \mathrm{C}\right)$ (McQuiston, 1982).

In the process of producing cooling and heating for buildings, the HVAC system consumes energy in the form of electricity, natural gas, oil and other sources. The total energy consumptions of commercial and institutional buildings account for $12 \%$ of Canada's secondary energy use and $11 \%$ of our national greenhouse gas (GHG) emission (NRCan, 2011). In the United States residential and commercial buildings consume over $40 \%$ of all the primary energy supply. They also represent over $72 \%$ of all electrical power generation and $55 \%$ of natural gas consumption. Table 1 shows that according to a 2009 report by Natural Resources Canada titled 
'Commercial and Institutional Energy Use-Building 2009', commercial office (non-medical) buildings make up 147.5 million $\mathrm{m}^{2}$ of floor space, which is $19.25 \%$ of all commercial and institutional buildings (NRCan, 2012).

Table 1: Building characteristics and energy use by primary activity (NRCan, 2012)

\begin{tabular}{|c|c|c|c|c|c|c|c|c|}
\hline \multicolumn{9}{|c|}{ Building characteristics and energy use by primary activity of the building } \\
\hline \multirow[b]{2}{*}{ Primaryactivity } & \multicolumn{2}{|c|}{ Buildings } & \multicolumn{2}{|c|}{ Floor space } & \multicolumn{2}{|c|}{ Energy use } & \multicolumn{2}{|c|}{ Energy intensity } \\
\hline & & Q.I. & $\begin{array}{l}\text { (millions } \\
\text { of } \mathrm{m}^{2} \text { ) }\end{array}$ & Q.I. & $(\mathrm{P}])$ & Q.I. & $\left(G \mid j m^{2}\right)$ & Q.I. \\
\hline Office building (non-medical) & 83583 & A & 147.5 & A & 176.6 & A & 120 & A \\
\hline Medical office building & 10525 & A & 9.6 & A & 10.5 & A & 1.09 & A \\
\hline Elementary or secondary school & 18425 & A & 83.6 & A & 64.4 & A & 0.77 & A \\
\hline Nursing or residential care facility & 6482 & A & 25.0 & B & 39.1 & $B$ & 1.56 & A \\
\hline Marehouse & 32879 & A & 83.0 & A & 55.0 & A & 0.66 & A \\
\hline Hotel or motel & 9963 & $\mathrm{C}$ & 19.7 & $B$ & 26.5 & $\mathrm{C}$ & 1.35 & A \\
\hline Hospital & 752 & A & 15.1 & A & 36.5 & A & 2.42 & A \\
\hline Food or beverage store & 40403 & A & 29.3 & A & 82.7 & A & 2.82 & A \\
\hline Non-food retail store & 56750 & A & 68.9 & A & 652 & A & 0.95 & A \\
\hline Other* & 222505 & A & 284.3 & A & 285.8 & A & 1.01 & A \\
\hline Canada & 482266 & A & 765.9 & A & 842.2 & A & 1.10 & A \\
\hline
\end{tabular}

Building overall energy performance can be improved by two ways:

- Improving construction of the building envelope to minimize transfer of heat and moisture through the wall, roof, windows and doors.

- Improving energy consumption of the HVAC system by optimizing design, and using fuel efficient equipment.

\subsection{Building Heating Ventilation and Air-Conditioning (HVAC) System}

As mentioned earlier, providing comfort condition in the building indoor environment is necessary for performance of the occupants. Building HVAC system maintains the indoor comfort condition by offsetting the heat gain/loss through building envelope, infiltration, fresh air and internal gain/loss. Building HVAC system is normally sized to meet annual peak heating and cooling demands though the peak conditions may happen for a very short time of the year. During the cooling mode the HVAC system removes heat from the indoor environment and releases the removed heat to the ambient; during the heating season, the HVAC system adds heat 
to the indoor environment to raise the space temperature. Common HVAC systems are three types:

- All air system

- Water to air system

- All water system

\section{All Air System:}

An all air HVAC system use only air to deliver heating and cooling to the space. It does not use any water to generate or transport energy. Normally cooling is produced by DX coils, and cooled air is blown into the indoor space by fans. Heating is produced by electric heater or gas burner. Supply fans are used for blowing air into the zones. Return fan draws room air, part of which is exhausted so that fresh outdoor air can be brought in through the supply fan. Part of the return air, which is already conditioned, is mixed with the fresh air, conditioned by the heating or the cooling system, and then re-circulated back into the indoor space by the supply air. A typical all air system is shown in Figure 6.

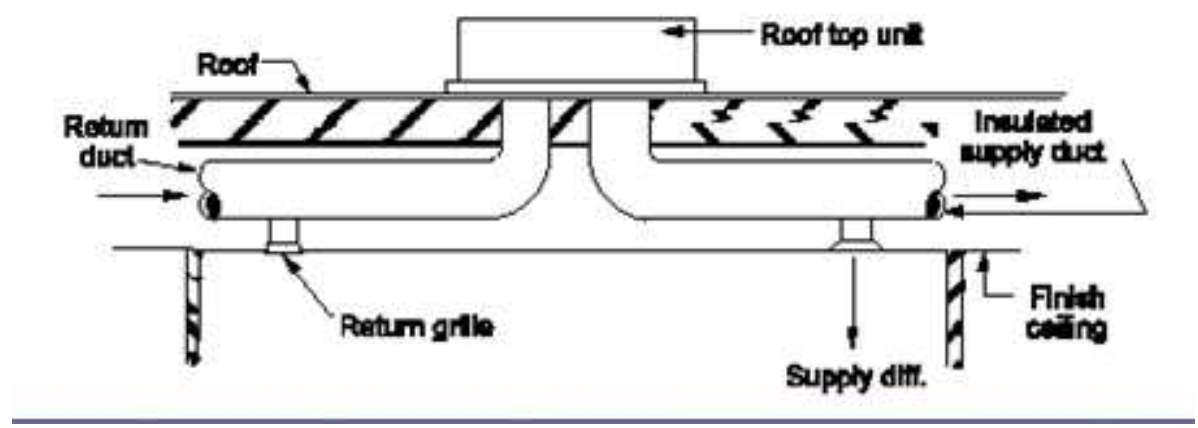

Figure 6: Example of an air system (Schneider Electric, 2006)

Water-to-air System:

Cooling is produced by a cooling unit, which can be of many types such as chiller, heat pump, cooling economizer, deep lake cooling system. Cold water is then transmitted through carrying pipe and circulated through cooling coil. During the heating season, hot water is produced by boiler, heat pump, solar heating system etc., and pumped through hot water pipes and finally circulated through hot water coils. For both heating and cooling, air is blown over the heating/cooling coil in order to bring the space supply air to design temperature. A typical 
water-to-air HVAC system is shown in Figure 7.

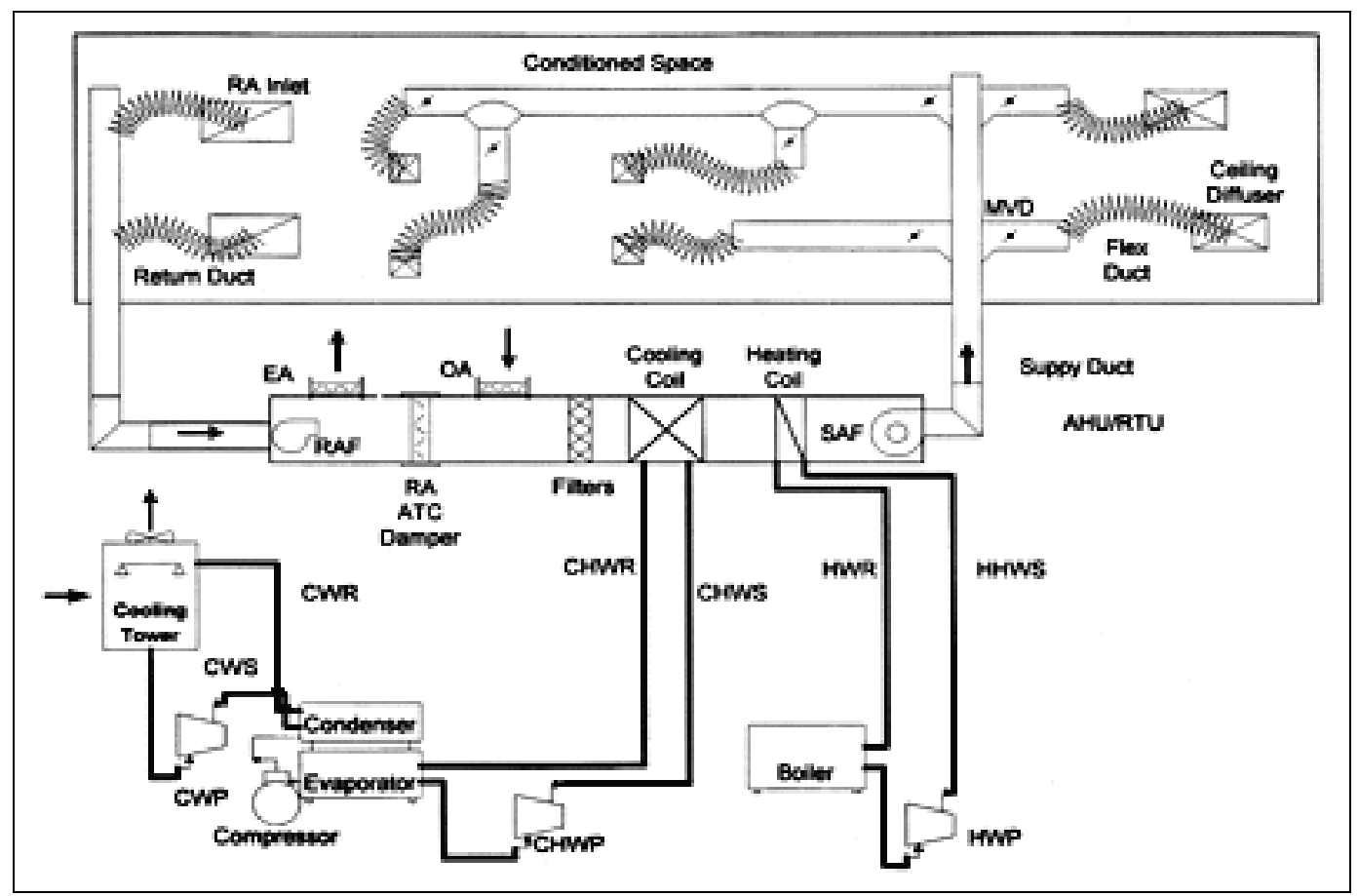

Figure 7: Example of a water-to-air HVAC system (Schneider Electric, 2006)

\section{All Water System:}

All water system does not use any fan to blow tempered air into the zone. Normally cooling and heating is produced in the central plant by cooling equipment such as chiller, heat pump etc. and heating equipment such as boiler, solar system etc. and transported through pipes to the individual zones. Depending on the cooling or heating demand, chilled or heated water is then circulated through coils or tubes, which emit heat to the space through radiation. Examples of all-water system are radiant floor heater, baseboard radiator, ceiling radiator etc.

In all of the above cases provision must be made to draw fresh outside air into the room to meet ASHRAE-62.1 minimum fresh air requirement.

Figure 8 shows screenshot of a sample air side HVAC system modelled in eQuest energy simulation software. 


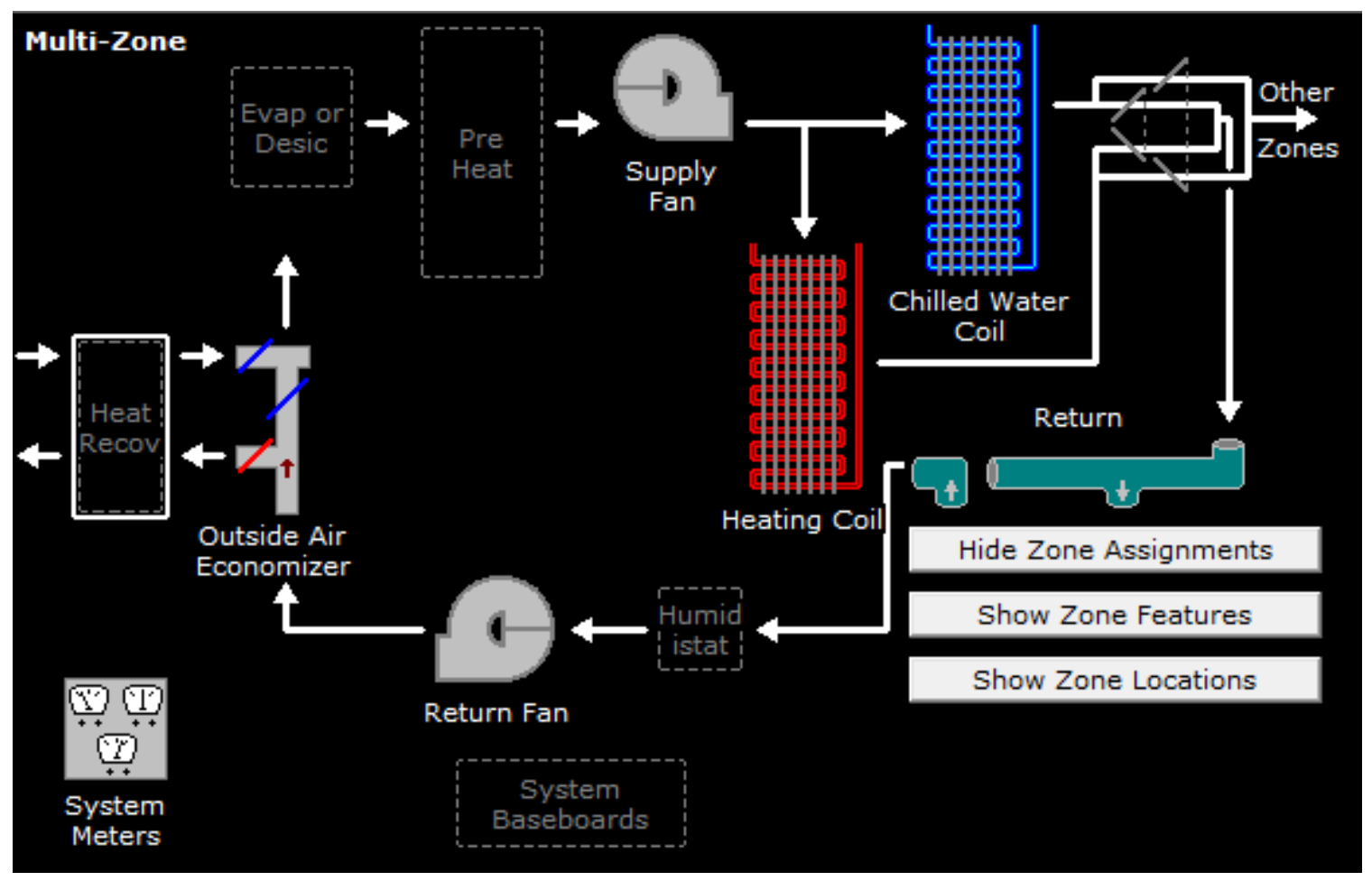

Figure 8: Building air system designed in eQuest

\subsection{Heat Pump Technology}

Traditionally heat pumps are designed based on vapor compression cycle. In the heating mode, heat is generally absorbed from the heat source (evaporator) and released to the zone (condenser) in requirement of heating. In the cooling mode, heat is extracted from the zone (evaporator), which requires cooling, and released into a relatively cooler heat sink (condenser). As this project involves water source heat pumps, water is the heat source in heating mode and heat sink in the cooling mode; room air is heat sink in the heating mode and heat source in the cooling mode. Different types of refrigerant gases are used in the vapor compression systems. Figure 9 illustrates a process flow of the refrigeration in a heat pump. 


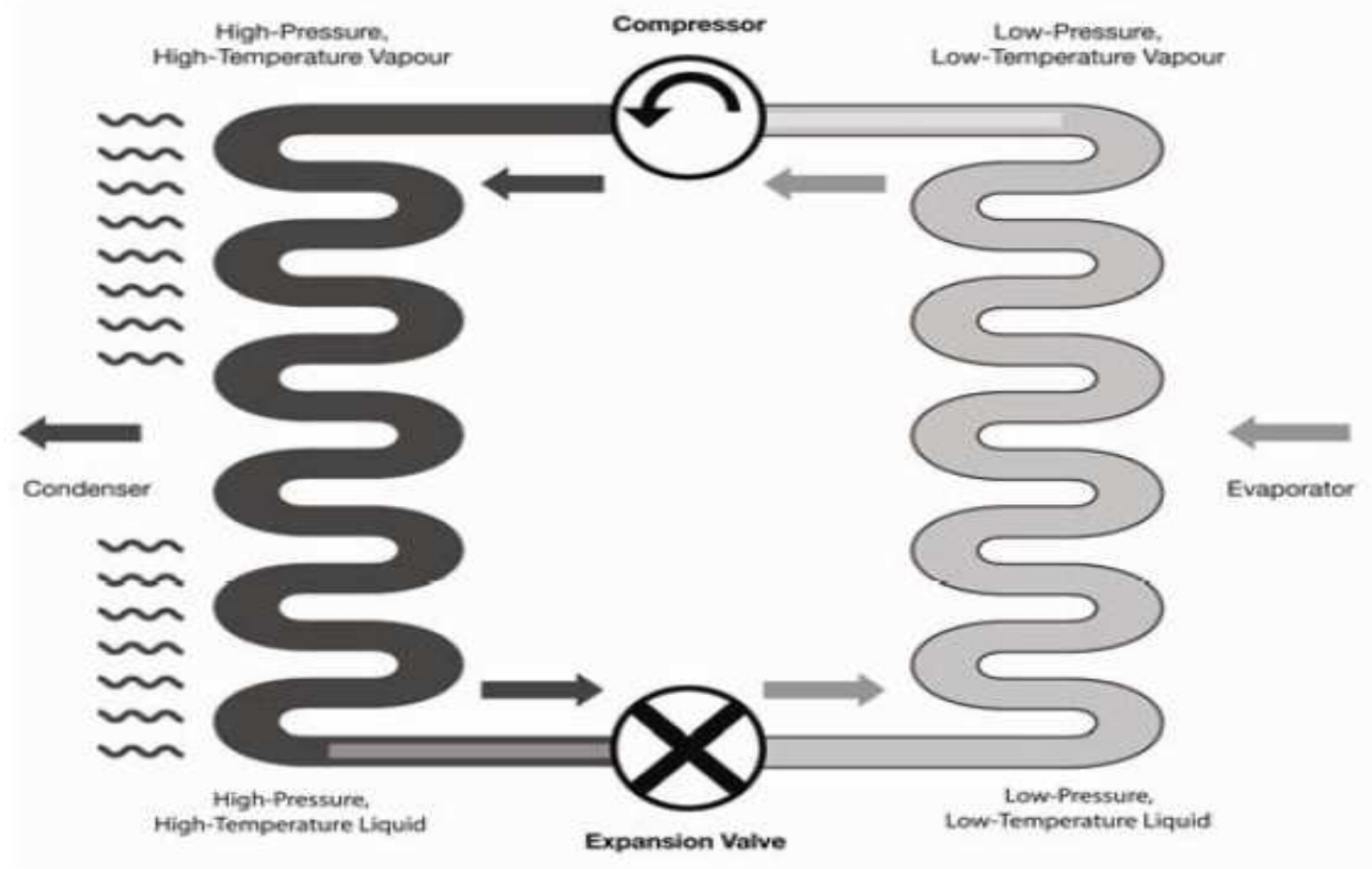

Figure 9: Heat pump cycle based on vapour compression (CEA Technologies)

Heat pump typically delivers or extracts much more heat than the work input provided to it. A heat pump can have coefficient of performance of 3.5 and higher depending of the supply water temperature (heat source), return air temperature (heat sink), water flow rate and air flow rate. This means that if the heat pump uses $1 \mathrm{~kW}$ of electricy, it can deliver $3.5 \mathrm{~kW}$ of heating or higher. Heat pump energy performance for heating can be calculated as:

$\mathrm{COP}=$ Heat Delivered $(\mathrm{kW}) /$ Electrical Energy Input $(\mathrm{kW})$

(Equation 1) Or, COP = Heating Energy Delivered $($ Btu/h) / (Energy input in Watts x 3.412 Btu/Watt-hour)

(Equation 2)

Heat pump efficiency for cooling can be shows as:

Energy Efficiency Ratio (EER) = Cooling Capacity (Btu/h)/ Energy input (watts) (Equation 3)

Cooling COP = Cooling EER/3.412 Btu/watt-hour

(Equation 4)

The higher the COP and EER are, the more efficient the heat pump is. Calculation of the COP 
and EER only considers the energy consumed by the compressor; energy consumed by fans or pumps are not included.

From the definition of COP it is seen that the heat extracted for cooling is higher than the heat rejected for heating, as the Heating Energy Delivered includes the energy introduced by the compressor.

For the Heating Operation:

$\mathrm{COP}_{\text {heat }}=\mathrm{Q}_{\mathrm{h}(\text { out })} / \mathrm{W}_{\mathrm{h}}$

(Equation 5)

$\mathrm{COP}_{\text {heat }}=\left(\mathrm{Q}_{\mathrm{h}(\mathrm{in})}+\mathrm{W}_{\mathrm{h}}\right) / \mathrm{W}_{\mathrm{h}}$

$\mathrm{Q}_{\mathrm{h}(\mathrm{in})}=\mathrm{COP}_{\text {heat }} \cdot \mathrm{W}_{\mathrm{h}}-\mathrm{W}_{\mathrm{h}}$

$\mathrm{COP}_{\text {heat }}$ is the coefficient of performance of the heat pumps during the heating operation; it can also be explained as the heat pumps' efficiency of adding heat to the space

$\mathrm{Q}_{\mathrm{h}(\mathrm{out})}$ is the heat added to the space by the heat pumps; also knows as the heating load

$\mathrm{Q}_{\mathrm{h}(\mathrm{in})}$ is the heat extracted from the common water loop by the heat pumps

$\mathrm{W}_{\mathrm{h}}$ is the work done by the heat pump compressor, defined as the heating-end-use energy ( $\mathrm{kWh}$ ) in the hourly report.

Similarly for the Cooling Operation:

$\mathrm{COP}_{\text {cool }}=\mathrm{Q}_{\mathrm{c}(\mathrm{in}) /} / \mathrm{W}_{\mathrm{c}}$

(Equation 8)

$\mathrm{COP}_{\text {cool }}=\left(\mathrm{Q}_{\mathrm{c}(\text { out })}-\mathrm{W}_{\mathrm{c}}\right) / \mathrm{W}_{\mathrm{c}}$

$\mathrm{Q}_{\mathrm{c}(\text { out }}=\mathrm{COP}_{\text {cool. }} \cdot \mathrm{W}_{\mathrm{c}}+\mathrm{W}_{\mathrm{c}}$

$\mathrm{COP}_{\text {cool }}$ is the coefficient of performance of the heat pumps during the cooling operation. It can also be explained as the efficiency of the heat pump to remove heat from the space.

$\mathrm{Q}_{\mathrm{c}(\mathrm{out})}$ is the heat added to the common water loop by the heat pumps

$\mathrm{Q}_{\mathrm{c}(\mathrm{in})}$ is the heat extracted from space by the heat pumps; also known as the space cooling load $\mathrm{W}_{\mathrm{c}}$ is the work done by the heat pump compressor, defined as the cooling-end-use energy ( $\mathrm{kWh}$ ) in the hourly report.

From Equation 1 to 10, it is evident that for the het balancing and heat re-use system to work; the daily total cooling load can be less than the daily total heat load of the space. This can also be 
formulated as:

$\mathrm{Q}_{\mathrm{c}(\mathrm{in})} \geq \mathrm{Q}_{\mathrm{h}(\mathrm{out})}-\mathrm{W}_{\mathrm{c}}-\mathrm{W}_{\mathrm{h}}$

(Equation 11)

Heat Pump Efficiency:

Heat pump efficiency will play a major role in determining how the zone loads should be balanced. Three major brands of heat pumps have been analyzed to examine the performance efficiency. Different sizes and associated energy performances are shown in Table 2, Table 3 and Table 4.

Table 2: Effinity Series water source heat pumps performance (Daikin McQuay, 2007)

\section{Enfinity Horizontal ISO Performance Data - Water Loop}

Water Loop Performance Data per ISO Standard 13256-1.

\begin{tabular}{|c|c|c|c|c|c|c|c|c|c|c|c|c|}
\hline \multirow{2}{*}{ UNIT SIZE } & \multicolumn{2}{|c|}{ AIRFLOW } & \multicolumn{2}{|c|}{ WATERFLOW } & \multirow{2}{*}{ VOLTAGE } & \multicolumn{4}{|c|}{ COOLING } & \multicolumn{3}{|c|}{ HEATING } \\
\hline & CFM & L/S & GPM & L/S & & BTU/HR & WATTS & EER & COP & BTU/HR & WATTS & COP \\
\hline 007 & 300 & 142 & 2.1 & 0.14 & $\frac{115-1-60}{208 / 230-1-60}$ & 8028 & 682 & 11.8 & 3.5 & 10715 & 744 & 4.2 \\
\hline 009 & 300 & 142 & 2.3 & 0.14 & $\frac{115-1-60}{208 / 230-1-60}$ & 8813 & 681 & 12.9 & 3.8 & 11769 & 745 & 4.6 \\
\hline 012 & 400 & 189 & 3.0 & 0.19 & $\begin{array}{c}\frac{115-1-60}{208 / 230-1-60} \\
265-1-60 \\
230-1-50\end{array}$ & 12941 & 1021 & 12.7 & 3.7 & 15804 & 1080 & 4.3 \\
\hline 019 & 630 & 297 & 5.3 & 0.33 & $\frac{208 / 230-1-60}{265-1-60}$ & 21000 & 6149 & 14.9 & 4.4 & 23600 & 6910 & 4.8 \\
\hline 024 & 800 & 378 & 6.2 & 0.39 & $\begin{array}{c}\frac{208 / 230-1-60}{265-1-60} \\
\frac{208 / 230-3-60}{460-3-60}\end{array}$ & 24700 & 7232 & 14.4 & 4.2 & 28400 & 8316 & 4.7 \\
\hline 030 & 1000 & 472 & 7.6 & 0.48 & $\begin{array}{c}\frac{208 / 230-1-60}{265-1-60} \\
\frac{208 / 230-3-60}{460-3-60}\end{array}$ & 30400 & 8901 & 15.3 & 4.5 & 36200 & 10600 & 5.0 \\
\hline 036 & 1200 & 566 & 9.0 & 0.57 & $\frac{208 / 230-1-60}{208 / 230-3-60} \frac{1}{460-3-60}$ & 35800 & 10483 & 15.2 & 4.5 & 42500 & 12444 & 4.9 \\
\hline 042 & 1400 & 661 & 10.7 & 0.68 & $\frac{208 / 230-1-60}{\frac{208 / 230-3-60}{460-3-60}} \frac{0}{575-60-3}$ & 43000 & 12591 & 15.0 & 4.4 & 50700 & 14845 & 5.0 \\
\hline 048 & 1600 & 755 & 12.3 & 0.78 & $\frac{208 / 230-1-60}{208 / 230-3-60}$ & 48400 & 14172 & 14.1 & 4.1 & 57100 & 16719 & 4.7 \\
\hline 060 & 2000 & 944 & 15.2 & 0.96 & $\begin{array}{c}208 / 230-1-60 \\
208 / 230-3-60 \\
460-3-60 \\
575-60-3\end{array}$ & 59500 & 17422 & 14.6 & 4.3 & 69400 & 20321 & 4.9 \\
\hline
\end{tabular}

Notes:

EER $=$ Energy Efficiency Ratio $\quad C O P=$ Coefficient of Performance $\quad L / s=$ Liters per second

Cooling capacity is based on $80.6^{\circ} \mathrm{F}$ db, $66.2^{\circ} \mathrm{F}$ wb $\left(27 / 19^{\circ} \mathrm{C}\right)$ entering air temperature and $86^{\circ} \mathrm{F}\left(30^{\circ} \mathrm{C}\right)$ entering water temperature.

Heating capacity is based on $68^{\circ} \mathrm{F}\left(20^{\circ} \mathrm{C}\right)$ entering air temperature and $68^{\circ} \mathrm{F}\left(20^{\circ} \mathrm{C}\right)$ entering water femperature. 
For the McQuay water source heat pump units, cooling COP ranges from 3.5 to 4.3, which implicates that if the compressor consumes $1 \mathrm{~kW}$ of electrical energy, the heat pump will extract 3.5 to $4.3 \mathrm{~kW}$ of heat from the zones that are in need of cooling. However, heat pumps operating in cooling mode will reject 4.5 to $5.3 \mathrm{~kW}$ of heat into the return water loop. Heating the COP ranges from 4.2 to 4.9 , which implicates that if the compressor introduces $1 \mathrm{~kW}$ of energy, 4.2 to $4.9 \mathrm{~kW}$ of heat will be provided to the zones that require heating. During the heating process, water source heat pumps will extract 3.2 to $3.9 \mathrm{~kW}$ of heat energy from the supply water.

Table 3: Tranquility series water source heat pump performance (ClimateMaster, 2014)

\begin{tabular}{|c|c|c|c|c|c|c|c|c|}
\hline \multirow{3}{*}{ Model } & \multicolumn{4}{|c|}{ Water Loop Heat Pump } & \multicolumn{4}{|c|}{ Ground Water Heat Pump } \\
\hline & \multicolumn{2}{|c|}{ Cooling $86^{\circ} \mathrm{F}$} & \multicolumn{2}{|c|}{ Heating $68^{\circ} \mathrm{F}$} & \multicolumn{2}{|c|}{ Coong $59^{\circ} \mathrm{F}$} & \multicolumn{2}{|c|}{ Heating $50^{\circ} \mathbf{F}$} \\
\hline & $\begin{array}{c}\text { Capacity } \\
\text { Btuh }\end{array}$ & $\begin{array}{c}\text { EER } \\
\text { Btuh/W }\end{array}$ & $\begin{array}{c}\text { Capacity } \\
\text { Btuh }\end{array}$ & COP & $\begin{array}{c}\text { Capacity } \\
\text { Btuh }\end{array}$ & $\begin{array}{c}\text { Bue } \\
\text { Btuh/wh }\end{array}$ & $\begin{array}{l}\text { Capacity } \\
\text { Btuh }\end{array}$ & COP \\
\hline TE026 Part & 19,200 & 19.8 & 23,600 & 7.0 & 22,000 & 34.1 & & 5.8 \\
\hline TE026 Full & 25,000 & 17.4 & 31,400 & 6.0 & 28,500 & 26.4 & & 5.3 \\
\hline TE038 Part & 27,400 & 20.1 & 32,600 & 6.5 & 30,700 & 34.4 & 27,300 & \\
\hline TE038 Full & 37,700 & 17.9 & 45,700 & 5.8 & 42,100 & 26.1 & 37,900 & 5.2 \\
\hline TE049 Part & 36,300 & 18.8 & 42,200 & 6.1 & 41,800 & 32.9 & 34,800 & 5.0 \\
\hline TE049 Full & 48,600 & 16.8 & 56,700 & 5.1 & 55,000 & 25.3 & 46,800 & 4.6 \\
\hline TE064 Part & 46,300 & 18.7 & 54,700 & 6.0 & 53,100 & 32.4 & 44,000 & 5.0 \\
\hline TE064 Full & 61,500 & 16.2 & 77,400 & 5.4 & 71,500 & 24.4 & 63,200 & 4.8 \\
\hline TE072 Part & 53,000 & 16.8 & 64,600 & 5.2 & 60,800 & 28.6 & 53,200 & 4.5 \\
\hline TE072 Full & 68,300 & 15.1 & 85,300 & 4.8 & 77,700 & 22.5 & 71,400 & 4.4 \\
\hline
\end{tabular}

Table 3 shows performance of the ClimateMaster Tranquility-30 series water source heat pumps. This variable speed heat pump's capacity can vary between 1.5 ton to 6 ton. At full load, cooling COP can range from 4.4 to 5.1 , which means for $1 \mathrm{~kW}$ of electrical energy consumed by compressor, the heat pump can remove 4.4 to $5.1 \mathrm{~kW}$ of heat from the zones required cooling, and reject the heat to the water loop. At full load, heating COP ranges from 4.8 to 6.0, which implies that for $1 \mathrm{~kW}$ of electrical energy consumed by the compressor, 4.8 to $6.0 \mathrm{~kW}$ of heat is provided to the space requiring heat; therefore 3.8 to $5.0 \mathrm{~kW}$ of heat is extracted from the water loop. Since the cooling load in the core zone is weather independent, the peak cooling load will 
persist throughout the year. The peak heating load will likely happen during the winter days in January. As this project aims to have a balanced load during the peak heating, only full load efficiencies will be used for modelling and analysis.

Table 4: Axiom series water-source heat pumps performance (Trane Inc., 2013)

\begin{tabular}{|c|c|c|c|c|c|c|c|c|c|c|c|c|c|c|}
\hline Model & $\begin{array}{c}\text { Rated } \\
\text { water } \\
\text { flow } \\
\text { (GPM) }\end{array}$ & $\begin{array}{c}\text { Rated } \\
\text { airflow } \\
\text { (SCFM) }\end{array}$ & \begin{tabular}{|c|} 
Cooling \\
capacity \\
WLHP \\
(BTUH)
\end{tabular} & $\begin{array}{c}\text { EER } \\
\text { WLHP }\end{array}$ & \begin{tabular}{|} 
Heating \\
capacity \\
WLHP \\
(BTUH)
\end{tabular} & $\begin{array}{c}\text { COP } \\
\text { WLHP }\end{array}$ & \begin{tabular}{|c|} 
Cooling \\
capacity \\
GWHP \\
(BTUH)
\end{tabular} & $\begin{array}{c}\text { EER } \\
\text { GWHP }\end{array}$ & $\begin{array}{c}\text { Heating } \\
\text { capacity } \\
\text { GWHP } \\
\text { QTUH) }\end{array}$ & $\begin{array}{c}\text { COP } \\
\text { GWHP }\end{array}$ & \begin{tabular}{|c} 
Cooling \\
capacity \\
GLHP \\
(BTUH)
\end{tabular} & \begin{tabular}{|c|} 
\\
EER \\
GLHP
\end{tabular} & $\begin{array}{c}\text { Heating } \\
\text { capacity } \\
\text { GLHP } \\
\text { (BTUP }\end{array}$ & $\begin{array}{l}\text { COP } \\
\text { GLHP }\end{array}$ \\
\hline EXHF006 & 1.8 & 215 & 7600 & 15.0 & 8800 & 4.9 & 8800 & 23.4 & & 4.4 & 8000 & 17.4 & & 3.4 \\
\hline EXHF009 & 2.1 & 285 & 9000 & 14.9 & 11100 & 5.4 & 10000 & 21.9 & 9100 & & 9400 & & 7000 & 3.8 \\
\hline EXHF012 & 2.8 & 380 & 11900 & 15.5 & 14600 & 5.2 & 14000 & 26.6 & 11900 & & 12700 & & 9000 & 3.6 \\
\hline EXHF015 & 3.5 & 475 & 15100 & 15.3 & 18300 & 4.8 & 17500 & 25.0 & 15200 & 4.2 & & 17.9 & 11300 & 3.4 \\
\hline EXHF018 & 4.2 & 570 & 19300 & 16.7 & 23300 & 5.1 & 20600 & 25.0 & 19100 & 4.5 & & 18.7 & 14200 & 3.6 \\
\hline EXHF024 & 5.6 & 760 & 23800 & 16.0 & 27700 & 4.8 & 25900 & 23.8 & 24100 & 4.5 & & 18.0 & 18800 & 3.6 \\
\hline EXHF030 & 7.0 & 950 & 30500 & 16.8 & 36200 & 5.4 & 33700 & 24.3 & 29600 & & 31600 & & 22700 & 3.7 \\
\hline EXHF036 & 8.4 & 1140 & 35200 & 17.0 & 44400 & 5.4 & 39700 & 25.8 & 36500 & 4.8 & 36700 & 19. & 28200 & 3.8 \\
\hline EXHF042 & 9.8 & 1330 & 42500 & 16.8 & 52400 & 5.3 & 45800 & 23.3 & 431 & 4.7 & 43700 & 18.5 & & 3.9 \\
\hline EXHF048 & 11.2 & 1520 & 47800 & 16.1 & 60000 & 5.3 & 52000 & 22.8 & 800 & 4.7 & 49100 & 17.7 & & 3.9 \\
\hline EXHF060 & 14.0 & 1700 & 58600 & 15.0 & 77800 & 4.9 & 64700 & 22.9 & 64100 & 4.4 & 61400 & 17.1 & 50400 & \\
\hline EXHF070 & 15.4 & 2090 & 66600 & 15.5 & 82100 & 4.5 & 70900 & & 68900 & 4.1 & 68500 & 16.9 & 52600 & \\
\hline
\end{tabular}

Table 4 shows performance of the Trane Axiom series water source heat pumps. This high efficiency heat pump's capacity can vary between 0.5 ton to 6 ton. At full load, cooling COP can range from 4.4 to 5.0 , which means for $1 \mathrm{~kW}$ of electrical energy consumed by compressor, the heat pump can remove 4.4 to $5.0 \mathrm{~kW}$ of heat from the zones required cooling, and reject the heat to the water loop. At full load, heating COP ranges from 4.5 to 5.4, which implicates that for $1 \mathrm{~kW}$ of electrical energy consumed by the compressor, 4.5 to $5.4 \mathrm{~kW}$ of heat is provided to the space requiring heat; therefore 3.5 to $4.4 \mathrm{~kW}$ of heat is extracted from the water loop.

From Table 2 to Table 4, it can be inferred that in order to have a balanced load condition, the proposed net zero building should have a higher cooling load than the heating load in winter peak conditions. Once the peak condition is balanced, ways of offsetting imbalance during the off-peak hours will be investigated and analyzed. 
1.6 Energy Efficiency Requirement for Internal Closed Loop Heat Pumps (NRCan, 2016)

Natural Resource Canada has published the minimum efficiency requirements (table 5) for heat pumps used in the distributed common loop heat pumps in an article titled "Internal water loop heat-pumps". The energy efficiency rating applies to water source heat pump not exceeding $40 \mathrm{~kW}(135,000 \mathrm{Btu})$ in heating/cooling as per the rating standard of CAN/CSA-C13256-1.

Table 5: Minimum COP requirements for heat pumps

\begin{tabular}{|c|c|c|}
\hline \multirow{3}{*}{$\begin{array}{l}\text { PRODUCT } \\
\text { CLASS }\end{array}$} & \multicolumn{2}{|c|}{ MINIMUM COP } \\
\hline & Cooling COPC & Heating COPh \\
\hline & \multicolumn{2}{|c|}{ November 2006} \\
\hline $\begin{array}{l}\text { Cooling } \\
\text { capacity } \\
<5 \mathrm{~kW}\end{array}$ & $\begin{array}{l}\geq 3.28 \text { with } 30^{\circ} \mathrm{C} \\
\text { inlet water }\end{array}$ & $\begin{array}{l}\geq 4.2 \text { with } 20^{\circ} \mathrm{C} \\
\text { inlet water }\end{array}$ \\
\hline $\begin{array}{l}\text { Cooling } \\
\text { capacity } \\
\geq 5 \mathrm{~kW} \text { and } \leq \\
40 \mathrm{~kW}\end{array}$ & $\begin{array}{l}\geq 3.52 \text { with } 30^{\circ} \mathrm{C} \\
\text { inlet water }\end{array}$ & $\begin{array}{l}\geq 4.2 \text { with } 20^{\circ} \mathrm{C} \\
\text { inlet water }\end{array}$ \\
\hline
\end{tabular}

1.7 ASHRAE 90.1 Standards (ASHRAE, 2013)

The purpose of ASHRAE 90.1 is to establish the minimum energy efficiency requirement of buildings other than low rise residential buildings, for:

- Design, construction and a plant for operations and maintenance, and

- Utilization of on site, renewable energy sources.

It sets a minimum energy efficiency standard for:

- New buildings and their systems.

- New portion of the buildings and their systems.

- New system and equipment in existing buildings.

The original Standard 90 was first published in 1975, and revised editions were published in 1980, 1989 and 1999 using the ANSI and ASHRAE periodic maintenance procedures. 
Prescriptive requirements of ASHRAE 90.1 2013 related to the building envelope, HVAC, DHW, power, lighting and auxiliary equipment will be used to design the base case commercial building.

Roof assembly maximum U-value $=0.032 \mathrm{Btu} / \mathrm{h}-\mathrm{ft}^{2} .{ }^{\circ} \mathrm{F}$

Roof assembly minimum R-value $=30$

Above grade wall maximum U-value $=0.080 \mathrm{Btu} / \mathrm{hr} . \mathrm{ft}^{2} .{ }^{\circ} \mathrm{F}$

Above grade wall minimum $\mathrm{R}$-value $=13.3$

Slab-on-grade floors minimum R-value $=\mathrm{R} 20$ for 24 inch along the exterior cavity

Opaque door maximum U-value $=0.500 \mathrm{Btu} / \mathrm{h}-\mathrm{ft}^{2}{ }^{\circ}{ }^{\circ} \mathrm{F}$

Vertical fenestration $(0 \%$ to $40 \%$ of Wall $)$ with non-metal framing, maximum U-value $=0.32$ $\mathrm{Btu} / \mathrm{h}-\mathrm{ft}^{2}{ }^{\circ} \mathrm{F}$

Vertical fenestration ( $0 \%$ to $40 \%$ of Wall) with non-metal framing, maximum solar heat gain coefficient $(\mathrm{SHGC})=0.40$

Vertical fenestration ( $0 \%$ to $40 \%$ of Wall) with non-metal framing, minimum visible transmittance $(\mathrm{VT})=0.44$

Skylight, $0 \%$ to $3 \%$ of Roof

$$
\begin{aligned}
& \text { Maximum U-value }=0.50 \mathrm{Btu} / \mathrm{h}-\mathrm{ft}^{2} .{ }^{\circ} \mathrm{F} \\
& \text { Max } \mathrm{SHGC}=0.40
\end{aligned}
$$

HVAC System Requirements:

Setback Control: Heating systems shall be equipped with controls configured to automatically 
restart and temporarily operate the system as required to maintain zone temperature above and adjustable heating setpoint at least 10F below the occupied heating setpoint. Cooling systems shall be equipped with controls configured to automatically restart and temporarily operate the mechanical cooling system as required to maintain zone temperature below an adjustable cooling setpoint at least $5^{\circ} \mathrm{F}$ above the occupied cooling setpoint or to prevent high humidity level.

Hydronic (water loop) Heat Pump Systems: Hydronic heat pumps connected to a common heat pump water loop with central devices for heat rejection (e.g. cooling tower) and heat addition (e.g. boiler) shall have the following:

Controls those are capable of providing a heat-pump water supply temperature dead band of at least $20^{\circ} \mathrm{F}$ between initiation of heat rejection and heat addition by the central devices (e.g. tower and boiler).

Fan Efficiency: Fans shall have a fan efficiency grade of $67 \%$ or higher based on manufacturers' certified data, as defined by AMCA 205. The total efficiency of the fan at the design point of operation shall be within 15 percentage points of the maximum total efficiency of the fan.

Boiler Turndown: Boiler systems with design input of at least 1,000,000 Btu/h shall comply with the turn-down ratio specified in Table 6.5.4.1

The system turndown requirement shall be met through the use of multiple single-input boilers, one or more modulating boilers, or a combination of single-input and modulating boilers.

All boilers shall meet the minimum efficiency requirements in Table 6.7.1-6

Hydronic Variable Flow System: HVAC pumping systems having a total pump system power exceeding $10 \mathrm{hp}$ that include control valves designed to modulate or step open and close as a function of load shall be designed for variable fluid flow and shall be capable of reducing pump flow rates to $50 \%$ or less of the design flow rate.

Hydronic heat pumps and water-cooled unitary air-conditioners having a total pump system power exceeding $5 \mathrm{hp}$ shall have controls and/or devices (such as variable-speed control) that 
will result in pump motor demand or no more that $30 \%$ of design wattage at $50 \%$ of design water flow.

Water source heat pump minimum cooling efficiency required at $86^{\circ} \mathrm{F}$ entering water temperature:

$<17,000 \mathrm{Btu} / \mathrm{h} ; 12.2 \mathrm{EER}$

$>=17,000 \mathrm{Btu} / \mathrm{h}$ and $<65,000 \mathrm{Btu} / \mathrm{h} ; 13.0 \mathrm{EER}$

$>=65,000 \mathrm{Btu} / \mathrm{h}$ and $<135,000 \mathrm{Btu} / \mathrm{h} ; 13.0 \mathrm{EER}$

Heating mode minimum efficiency at $68^{\circ} \mathrm{F}$ enter water temperature: $4.3 \mathrm{COP}$

Gas fired heating boiler minimum annual fuel usage efficiency (AFUE) $=80 \%$

Minimum efficiency of propeller or axial fan cooling tower rated at $95^{\circ} \mathrm{F}$ entering water, $85^{\circ} \mathrm{F}$ leaving water and $75^{\circ} \mathrm{F}$ entering wet bulb $=40.2 \mathrm{gpm} / \mathrm{hp}$.

Electrically operated multi-split heat recover air-to-air variable flow applied heat pup cooling mode minimum efficiency:

$>=65,000 \mathrm{Btu} / \mathrm{h}$ and $<135,000 \mathrm{Btu} / \mathrm{h}: 10.8 \mathrm{EER}$ and 12.1 IEER

1.8 eQuest Building Simulation (Nall and Crawley, 2011)

Building energy simulation programs have been in existence for about 18 years. Initially, they were commissioned by gas and electricity utility associations to influence designers in the selection of gas or electric systems. Subsequent development of programs was sponsored by the federal government with North Baltimore Local School Board (NBLSD) as a research tool and the U.S. Post Office programs a compliance tool for design guidelines. These federal efforts have culminated in the BLAST and DOE-2 programs available today. This project utilizes energy simulation software eQuest V3.65, which is a DOE-2 based building energy simulation wizard. eQuest combines the DOE-2 engine with a building creation wizard and an energy efficiency measure (EEM) wizard. The building creation wizard can be used to create a complete building using steps that take input in the following design aspects, which contribute to building energy consumptions:

- Architectural design. 
- HVAC design and equipment.

- Building type and size.

- Floor plan layout.

- Construction material.

- Area usage and occupancy distribution.

- Lighting and internal equipment.

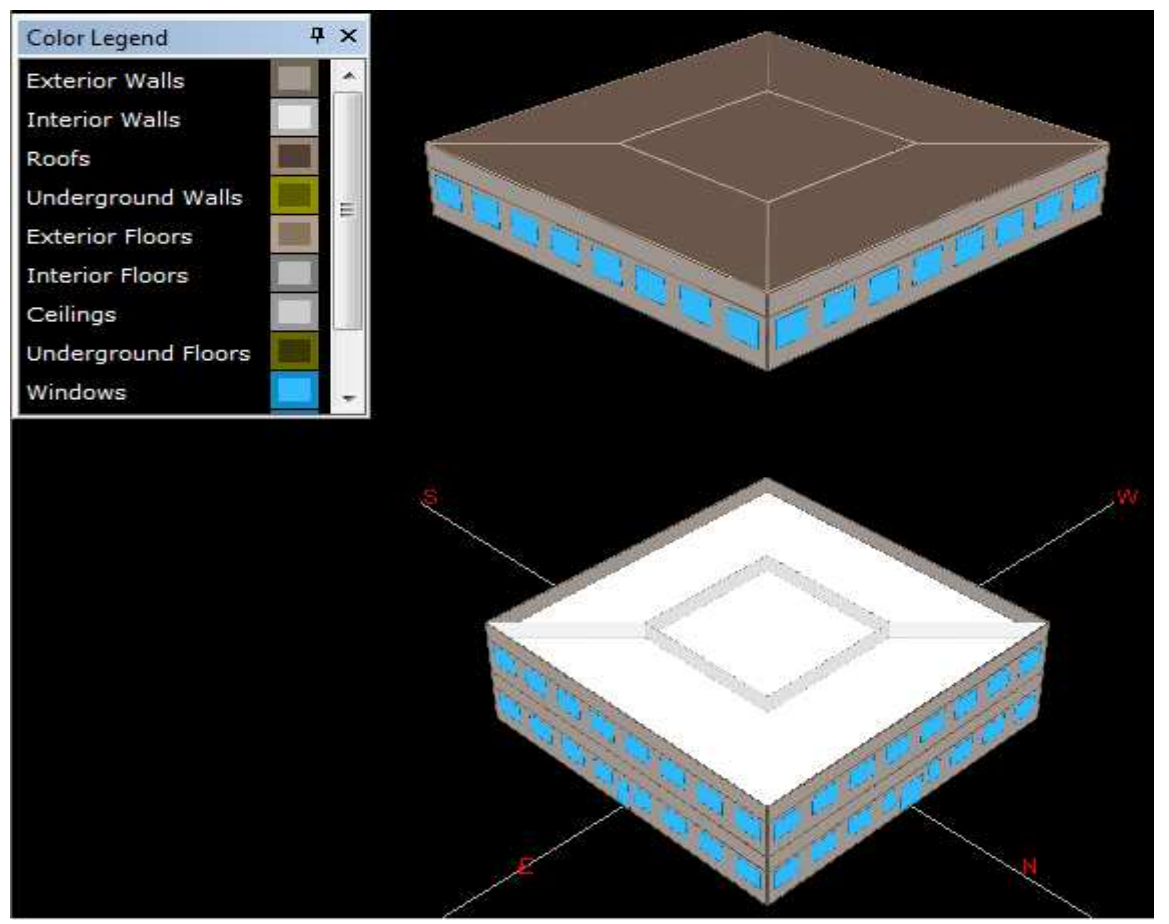

Figure 10: Sample base building model in eQuest

After compiling the complete building information, eQuest produces a detailed simulation of the building, heating and cooling load calculation and annual energy consumption of the building. eQuest performs hourly simulation of the building using local weather data for an entire year using the following information:

- Walls

- Windows

- Glass

- People

- Plug load 


\section{- Ventilation}

The DOE engine simulates the performance of fans, pumps, chillers, boilers and other energy consuming equipment. Once a simulation is complete, eQuest produces graphic results of estimated monthly and yearly energy consumptions.

\subsection{HVAC Zoning in eQuest (Hirsch \& Associates, 2009)}

The official eQuest tutorial published by Hirsch describes that HVAC zoning recognizes that the load profiles seen by different spaces in a building differ. It is suggested that areas with similar load profiles be grouped under the same thermostat control to improve comfort and save energy. The zone temperatures are effected by internal gains, solar gains, and envelope gains and losses. The following factors should be considered when creating zones in eQuest:

- Magnitude and schedule of internal loads

- Magnitude and schedule of solar gains

- Schedule of fan system operations

- Outside air temperature

- Intended efficiency measures

- One exterior zone per major orientation (12 to $18 \mathrm{ft}$ deep)

- One internal zone per use schedule

- One zone each for special uses such as conference rooms, cafeterias etc.

- Separate ground and top floor zones.

\subsection{Net Zero Energy Building (Duncan, 2009)}

A Net Zero Energy Building (NZEB) must achieve an operating net zero energy demand, which means that the total energy consumed by building must be met by the energy produced within the site. The choice of building façade, mechanical systems and occupant behaviour has significant impact on the design of the NZEB. Envelop energy demands include sensible conduction and solar load, whereas infiltration contributes to latent and sensible gain/loss. Occupancy energy consumption involves sensible and latent heat gain due to occupants, lighting and equipment. Building system energy efficiency involves HVAC system efficiency, configuration and control strategies. The first step to design a net zero building is estimating the 
building's energy demand by performing energy model, which predicts building load and energy consumption. Initially the building is modelled to represent ASHRAE 90.1-2010 minimum energy efficiency requirement, which recommends energy densities and schedules for occupancy, lighting and equipment/plug load gains. The base case is then improved and simulated for better energy performance of the building. For a large office, the gains to a space are dominated by windows solar transmittance and thermal conductance, occupant, lighting and equipment load. In winter, heat is lost through the walls and windows by conduction, whereas heat is gained due to solar transmittance through the windows. Proper solar shading practice can reduce heat gain in summer and increase heat gain in winter. High performance façade significantly reduces solar gain and infiltration load. A large portion of the load comes from the plug and lighting load during the cooling season. These can be addressed by optimizing daylight penetration, internal lighting controls and use of energy efficiency appliances. 


\section{Literature Review}

A set of publications and case studies have been reviewed, which will be used as the guiding principle for creating a methodology of the design of a net zero energy building, heated and conditioned by common loop water source heat pumps systems.

\subsection{Simulation Overview (Clarke, 2001)}

In the book "Energy Simulation in Building Design", Clarke has presented overview, method and validation technique of energy simulation. Clarke presented that buildings typically account for around $50 \%$ of the total energy consumption in a developed country and similar portion of the carbon dioxide emission. Building energy simulation approach is able to address all aspects of a building's life cycle and thereby help designers to strike a balance between energy use, indoor comfort and local/global impact. A brief summary of simulation overview and thermo physical factors of a building have been extracted from Clarke's book.

A building interacts in a dynamic manner to dictate comfort levels and energy demands. Components that contribute to the load and energy of a building are constructional elements, room contents, glazing systems, occupancy, use, plant system, HVAC distribution system, lighting and internal equipment. Our focus on building energy analysis here is mainly based on energy consumed by building heating, ventilating and air-conditioning (HVAC) system, which is linked to building heat transfer processes that are highly inter-related. Therefore it is necessary to apply simultaneous solution techniques if the performance is to be both accurate and preserve the spatial and temporal integrity of the modelled system. These simultaneous heat transfer processes involve a large number of complex equations combined to present heat transfer and energy consumption process of a complex building system. A simulation process can be utilized throughout the design process from the early concept stage through the detailed design. It helps owners and designer to make the right decision in terms of their energy focus and financial feasibility. There are a number of building simulation programs; however it is more efficient to use a single program throughout the design process than use a progression of tools. This will help to use theoretical discontinuities and pernicious assumptions. Simulation tools can be used at multiple stages of the design; each simulation can optimize a single aspect of the building 
design. It is possible to use a simulation program to determine the optimum combination of zoning and constructional scheme that will provide a climate responsive solution and minimize the need for a mechanical plant. Some simulation might focus on the choice of construction materials and their relative positioning within multi-layered construction so that good temperature and load leveling is attained. Simulation can also be used to perform optimum daylight capture and shading strategies in order to utilize sunlight to gain heat during colder season, while avoid solar heat gain during the summer/cooling months. This strategy may involve optimized sizing and material selection for gaining solar heat during the winter, while reducing conductive heat loss. In the summer months, the simulation will aim for minimizing both solar heat gain as well as conductive heat transfer between the ambient and the indoor environment; a shading strategy can be effectively used for such scenario. In both summer and winter cases, optimum daylight capture can reduce use of lighting in the perimeter zones.

Once the physical characteristics of a building are decided upon for the anticipated scenarios, different control strategies can be simulated for energy usage reduction while maintaining desired indoor environment. Basic control strategies will help to decide on the start stop control of HVAC systems, appropriate temperature setback during unoccupied hours, location of sensors and interrelation of thermal and visual comfort variables. To further stress on these scenarios, one can design and simulate HVAC system controls in terms of how the system will turn on and off on demand or whether the HVAC equipment will just modulate according to the heating/cooling demand or how should the equipment respond from the sequence of operation perspective. Similarly sensors can be integrated in the model to test benefits of occupancy sensor driven lighting control, day light control to optimize natural light and solar heat gain/heat loss and HVAC temperature setbacks.

Building energy consumption by HVAC system is directly influenced by various heat and mass transfer between the ambient and the indoor environment. A good simulation software should simultaneously process all energy transport paths, and the HVAC system, which maintains desired indoor environment by converting energy (electricity, natural gas etc.) into heating and cooling. Major factors influencing heat and cooling loads are briefly discussed here. 
Conduction Loss/Gain: This can be defined as the heat transfer through the envelope of the building due the temperature difference between the indoor and the outside. Building envelop consists of the walls, windows, doors, roof and the floor which is in contact with the earth. The rate at which heat travels through the building envelope is a deciding factor in the heating and cooling load of a building. The thermo physical properties influencing heating/cooling load are conductivity, $\mathrm{k}\left(\mathrm{Btu} / \mathrm{ft} .^{\circ} \mathrm{F}\right)$, density, $\rho\left(\mathrm{lb} / \mathrm{ft}^{3}\right)$ and specific heat capacity, $\mathrm{C}_{\mathrm{p}}(\mathrm{Btu} / \mathrm{lb} . \mathrm{F})$. By combining these three factors, overall thermal transmittance $U(B t u / f t 2 . F)$ of the wall can be found. As the goal of this project is not to analyze the calculation methods of the heat loss/heat gain, it is only important to understand how the conductive heat loss takes place and using its knowledge to optimize envelope construction of the intended office building.

Surface Convection: Convection is the process of exchanging the heat flux between a surface and the adjacent air layer. In the case of the ambient, convection is wind induced and considered as forced convection, whereas in the indoor environment, convection is natural unless mechanical forced flow is used. In energy simulation it is normal practice to make use of time varying, but surface-averaged convection coefficience $h_{c}\left(B t u / \mathrm{ft}^{2}{ }^{\circ} \mathrm{F}\right)$. Typically for external building surfaces, wind speed and direction data are available for some reference height. Convective heat loss and heat gain will be different with building shape, orientation and aspect ratio. Wind direction will cause higher convective heat loss/gain in certain perimeter areas than the other.

Internal Surface Long Wave Radiation: Long wave radiation is a function of the prevailing surface temperature, the surface emissivities, the extent to which the surfaces are in visual contact and the nature of the surface reflection. Generally windows with low emissive increase the reflection of longwave solar radiation and breaks inter surface heat exchange. Optimization of solar radiation will be experimented in order to balance thermal load of the building.

Shortwave Radiation: This is the solar energy gain which constitutes and significant portion of the cooling load and which can offset some of the heating load in winter. Proper treatment of the solar radiation can help reduce the heating load in the perimeter zones. When solar energy impinges on any glazing, it is partially reflected and partially transmitted into the indoor space. The transmitted beam strikes internal surfaces where it goes through absorption, reflection and 
transmission. The heat flux is then stored and lagged in the internal surfaces, thus giving rise to the solar heat gain. The thermo physical properties of interest include shortwave absorptive for opaque elements and absorptive, transmissivity and reflectivity for transparent elements.

Shading and Insolation: The solar energy incident on a building is influenced by shading as caused by parts of itself, surrounding buildings, façade features and natural obstructions such as trees. Shading and insolation are therefore function of solar position and target geometry. The design optimization strategy is to use design parameters such as orientation, shape and obstruction geometry to so modify the shading/insolation patterns that environmental performance is improved without recourse to mechanical intervention.

\subsection{Building Envelop Design for Energy Balance (Chwieduk, 2014)}

Solar Thermal Efficiency of Building Envelope:

A number of recommendations were made concerning shaping of building envelopes in high altitude countries based on simulation by Sodha. Since the principle objective of this project is to balance load during winter and shoulder seasons, recommendations are provided to optimize solar gain in those two periods.

In the winter, because of poor solar irradiation, recommendations are very strict.

- The façade should be opened for solar radiation from the south. Envelope of a building must not be shaded by elements of a building architecture or surrounding objects. If any extended curved of the south façade is used, the glazed part should have azimuth angles from $-30^{\circ}$ to $+30^{\circ}$.

- It is recommended to use envelope elements with high tilt angle, sloped roofs with tilt in ranges from 50 to 70 . Horizontal surfaces and surfaces with small tilt angle should be avoided.

- The main façade in the south should be large grazed surface.

- Innovative materials can be proposed including smart windows with transmittivity for solar radiation depending on the angle of the inclined solar radiation, and length of the radiation wave.

- Northern parts of the building envelope are the least exposed to solar radiation. 
Therefore storages, depots, technical facilities should be placed in the north most rooms. The number of windows should be minimized.

- The eastern parts of the building can be used for offices and meeting rooms, which require good daylight access during the morning hours. In summer time, these rooms will be much less heated than the ones located at the south and the west side of the building.

Direct solar gain can reduce heating load in the winter season. A direct solar gain is utilized by the room as it enters directly through windows and doors. Solar radiation passes through windows glazing, which acts as a transparent cover of the solar energy receiver (the room). Depending of the solar radiation absorptance of the surfaces of the internal walls, solar radiation is absorbed and stored for a period. The stored heat is normally exchanged between medial of different temperatures, thus the temperature within the room increases. Enlarging glazing area in the sides more exposed to solar radiation can add radiance heat to the perimeter area of the building. During the winter, large glazing also causes heat loss to the ambient. In the case of the modern windows with compact glass panes, more heat is transferred through the framing than the through the glazing, thus the frame area needs to be reduced. Large glazing can cause the indoor temperature change considerably and sharply through both heat gain and heat loss. In winter, transmittance of the solar gain should be as high as possible, while the windows should have high thermal resistance to prevent heat to be lost to the ambient. Heat insulation characteristics of the windows not only depend on the material of the glazing, but also on the entire window design, including the number of glass layers, assembly method, material and thermal performance of framing and gap between panes. Heat transfer through the central part of the window panes are relatively low, but heat transfer is significant at the edges where the panes make contact with the frame. Since metal spacers act as heat transfer medium, spacers with high insulation value should be used. Once recommendation for design window is the so-called solar glass with low iron content which gives the window high transmittance for solar radiation and low transmittance for thermal radiation. Electromagnetic glazing has been recommended in the book titled Solar Energy in Buildings. There are many different types of windows with different optical properties, and therefore different coefficients of solar radiation gains. Commonly double-glazed windows and triple-glazed windows are used. In modern compact windows, gaps between panes are billed with noble gas like argon and krypton. Different materials low 
conductance such as wood or plastics with chambers filled with air or insulation can be used for framing.

Thermal resistance of a glazing is the sum of all the elementary resistance such as external thermal resistance, thermal resistance of the glazing and the internal thermal resistance. Thermal resistance of a double or triple pane window with air gaps depends on the intensity of the heat transfer phenomena of the glass material and the gap. In order to reduce heat exchange through thermal radiation, low-emission coating on the inner glass pane surfaces are used. Convective heat loss can be reduced by using proper gap between the glass panes and filling the gap with a noble gas or even creating vacuum gap. It is important to improve thermal insulating characteristics of windows. Apply low emissivity coating on the internal surface of the inner glass pane, increases thermal resistance of the double-glazed windows more than twofold. Filling the air gap between panes with noble gas reduces convective heat transfer because noble gases have fewer particles than air. In an old standard double-glazed window with an air-filled gap, the heat transfer coefficient during winter is $0.504 \mathrm{Btu} / \mathrm{h}-\mathrm{ft}^{2}{ }^{\circ} \mathrm{F}\left(2.86 \mathrm{~W} / \mathrm{m}^{2} . \mathrm{K}\right)$ and during summer $0.595 \mathrm{Btu} / \mathrm{h}-\mathrm{ft}^{2}{ }^{\circ} \mathrm{F}\left(3.38 \mathrm{~W} / \mathrm{m}^{2} . \mathrm{K}\right)$. The solar heat gain coefficient SHGC is 0.76. A double glazing with low-emissivity coating on the inner surface of the inner pane $(\varepsilon=0.08)$ and an argon-filled gap, the heat transfer coefficient is $0.137 \mathrm{Btu} / \mathrm{h}-\mathrm{ft}^{2} .{ }^{\circ} \mathrm{F}\left(0.78 \mathrm{~W} / \mathrm{m}^{2} . \mathrm{K}\right)$ for winter and $0.157 \mathrm{Btu} / \mathrm{h}-\mathrm{ft}^{2}{ }^{\circ} \mathrm{F}\left(0.89 \mathrm{~W} / \mathrm{m}^{2} . \mathrm{K}\right)$ for summer. The Solar Heat Gain coefficient is 0.45 .

\section{Energy Balance of a Building:}

Any building is influenced by its external surroundings, especially climatic conditions including solar radiation. The thermal interaction with the surrounding is influenced by building architectural and structural designs, which should increase solar radiation in winter and reduce solar gain in summer. This also requires using transparent elements of building façade of high transmittance as well as opaque elements of high absorptance for solar gain in winter.

The energy balance of a building is influenced by heat flows through its envelope, air flow through infiltration through the building envelope, air flow through ventilation and heat gain from internal heat sources. Due to the heat loss/gain factors changing with time, the internal temperature also change; the requirement for heat generation from an external source also change. Considering the heat flow into and out of the building, and the internal heat gain, the following is the expression of a building energy balance: 


$$
\rho c V \frac{d T_{\text {in }}}{d t}=\sum \dot{Q}_{\text {in }}(t)-\sum \dot{Q}_{\text {out }}(t)+\sum \dot{Q}_{q v}(t)
$$

where:

$\sum \dot{Q}_{i n}(t)=$ the sum of energy fluxes flowing into the interior through elements of a building envelope (W);

$\sum \dot{Q}_{\text {out }}(t)=$ the sum of heat fluxes flowing out of the interior through elements of a building envelope (W);

$\sum \dot{Q}_{q v}=$ the sum of internal heat sources in a building (room) (W);

$T_{i n}(t)=$ the air temperature inside a building (room) $(\mathrm{K})$;

$V=$ the air volume inside a building $\left(\mathrm{m}^{3}\right)$.

Energy balance including solar radiation flux will be the following:

$$
(\rho c V) \frac{d T_{i n}}{d t}=\dot{Q}_{i n}(t)+\dot{Q}_{h}(t)+\dot{Q}_{s o l}(t)-U_{t}(t) A_{t}\left(T_{i n}(t)-T_{a}(t)\right)-\dot{Q}_{v e n}(t)
$$

Here $\mathrm{Q}_{\text {in }}$ is internal heat gains, $\mathrm{Q}_{\text {sol }}$ is solar radiation gains, $\mathrm{Q}_{\mathrm{h}}$ is heat flow supplied by the heating system in the building, $\mathrm{Q}_{\mathrm{ven}}$ is the heat requirement to temper the ventilation air depending on the outdoor temperature and $U_{t}$ is the heat transfer coefficient for all the envelope elements and their surfaces.

If the entire building is heated at a given time and the temperature is maintained constant, then the whole building is considered as one temperature zone. However, due to different exposure level to sun and different internal gains, different areas of the building have different heating/cooling demand; thus applying several temperature zones is adopted depending on the location and function of different rooms. Heat fluxes through different envelope elements characterized by specific thermal resistance coefficients, are exchanged between the building's interior of a certain air temperature and its exterior of ambient air, the sky temperature, and ground temperature variable in time. Internal heat sources are people (approximate heat output 50-100W/person depending on activity) appliances, devices, light sources and equipment. In some cases heat provided by the internal source may be high enough, that the interior zone may not have any heating load, and sometime cooling might be required. Figure 11 shows interaction between a building and its surroundings. 


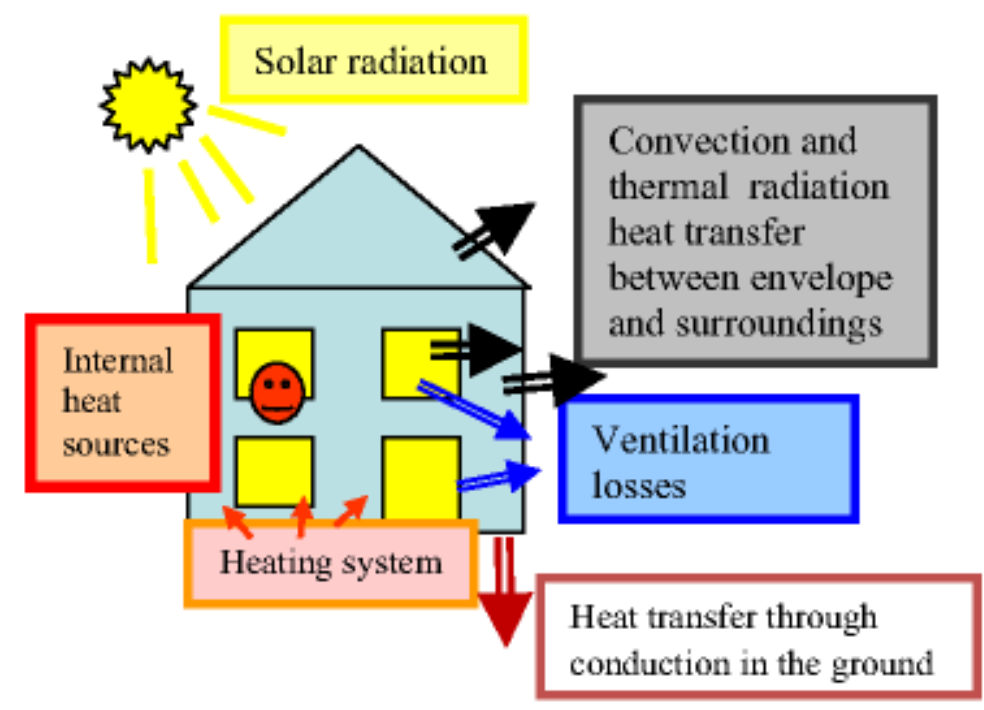

Figure 11: Energy transfer between a building and its surroundings (Chwieduk, 2014)

To minimize heat loss/gain, heat stored inside a building should stay inside as long as possible by using envelope elements of high thermal capacity, which gives an element the ability to store large amount of heat. Heat storage capacity is related to high thermal mass, volume, density and specific heat.

\subsection{Net Zero Energy Building Design}

Net Zero Design and Energy Basics: In the book titled Net Zero Energy Design, by Thomas Hootmat, the relationship between building architectural design and energy used has been emphasized. Hootman mentions that energy and architecture have always been intertwined. Architecture has always been formed by energy; it has been used to both mediate and harness the energy of the world. Hootman also explores work by Luis Fernandez-Galiano, who emphasizes on the importance of energy in architectural history. He refers to two fundamental interactions of energy and architecture; "regulation of free energy through construction" and "exploitation of accumulated energy through combustion". Net zero energy design offers architects an opportunity to reengage in one of the fundamentals of architectural design, which combines the rigors of building science and the expression of the purpose and meaning of energy in architecture (Hootman, 2013).

Climate condition dictates the heating and cooling loads at the building envelope. In severe 
climate like Canadian weather, thermal energy transfer between indoor environment of a building and the ambient can account for a large portion of the overall energy use of a building. Due to being mainly cold \& dry and having heating-degree day (HDD) measured between $7200<\operatorname{HDD}\left(65^{\circ} \mathrm{F}\right)<9000$, Toronto is designated as climate zone 6B by ASHRAE. Table 6 and Figure 12 demonstrate climate zone designation and energy use intensity (EUI) in commercial buildings.

Table 6: Climate zone definition (Hootman, 2013)

\begin{tabular}{|l|l|l|}
\hline Zone No. & Climate Zone Type & Degree-days Criteria \\
\hline $1 \mathrm{~A}$ & Very Hot-Humid & $9000<\mathrm{CDD} 50^{\circ} \mathrm{F}$ \\
\hline $1 \mathrm{~B}$ & Very Hot-Dry & $9000<\mathrm{CDD} 50^{\circ} \mathrm{F}$ \\
\hline 2A & Hot-Humid & $6300<\mathrm{CCD} 50^{\circ} \mathrm{F} \leq 9000$ \\
\hline 2B & Hot-Dry & $6300<\mathrm{CCD} 50^{\circ} \mathrm{F} \leq 9000$ \\
\hline $3 \mathrm{~A}$ & Warm-Humid & $4500<\mathrm{CDD} 50^{\circ} \mathrm{F} \leq 6300$ \\
\hline $3 \mathrm{~B}$ & Warm-Dry & $4500<\mathrm{CDD} 50^{\circ} \mathrm{F} \leq 6300$ \\
\hline $3 \mathrm{C}$ & Warm-Marine & $\mathrm{HDD} 65^{\circ} \mathrm{F} \leq 3600$ \\
\hline $4 \mathrm{~A}$ & Mixed-Humid & $\mathrm{CDD} 50^{\circ} \mathrm{F} \leq 4500$ and HDD65 $\mathrm{F} \leq 5400$ \\
\hline $4 \mathrm{~B}$ & Mixed-Dry & $\mathrm{CDD} 50^{\circ} \mathrm{F} \leq 4500$ and HDD65 $\mathrm{F} \leq 5400$ \\
\hline $4 \mathrm{C}$ & Mixed-Marine & $3600<\mathrm{HDD} 65^{\circ} \mathrm{F} \leq 5400$ \\
\hline 5 & Cool-Humid & $5400<\mathrm{HDD} 65^{\circ} \mathrm{F} \leq 7200$ \\
\hline $5 B$ & Cool-Dry & $5400<\mathrm{HDD} 65^{\circ} \mathrm{F} \leq 7200$ \\
\hline $5 \mathrm{C}$ & Cool-Marine & $5400<\mathrm{HDD} 65^{\circ} \mathrm{F} \leq 7200$ \\
\hline $6 \mathrm{~A}$ & Cold-Humid & $7200<\mathrm{HDD} 65^{\circ} \mathrm{F} \leq 9000$ \\
\hline $6 B$ & Cold-Dry & $7200<\mathrm{HDD} 65^{\circ} \mathrm{F} \leq 9000$ \\
\hline 7 & Very Cold & $9000<\mathrm{HDD} 65^{\circ} \mathrm{F} \leq 12600$ \\
\hline 8 & Subarctic & $12600<\mathrm{HDD} 65^{\circ} \mathrm{F}$ \\
\hline
\end{tabular}




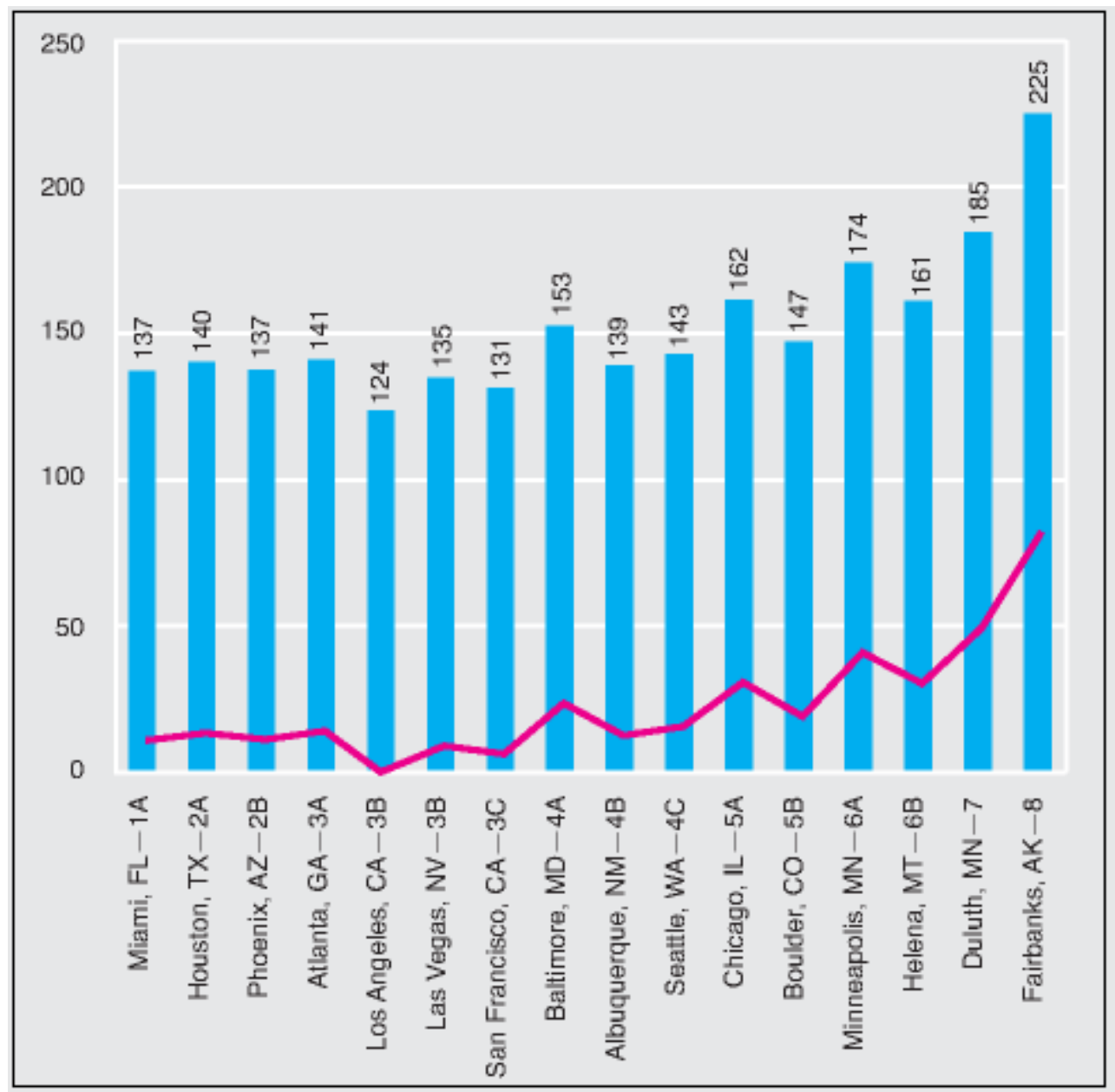

Figure 12: Annual Energy Use Intensity ( $\mathrm{kBtu} / \mathrm{ft}^{2} /$ year) of commercial buildings in different zones based on average of 16 commercial building types (Hootman, 2013)

Figure 13 shows energy use intensity of commercial and institutional buildings by activity type in Canada. 


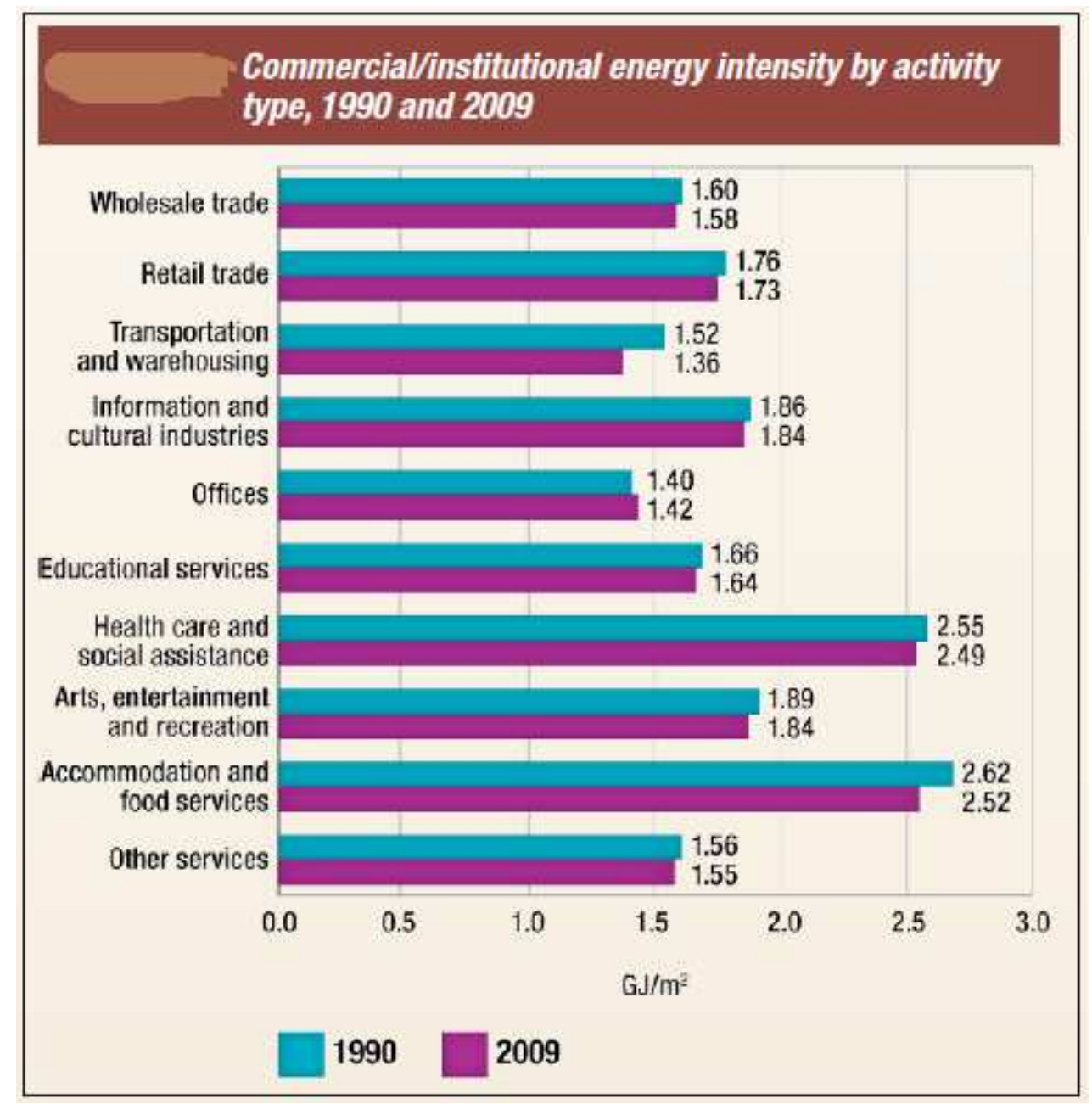

Figure 13: Commercial/institutional building energy intensity by activity type (NRCan, 2011)

The first step in establishing in energy target is setting a baseline for the design of a new building. A common energy standard is ASHRAE 90.1 "Energy Standard for Buildings except Low-rise Residential Buildings", which establishes a minimum code performance standard for the specific building under construction (Hootman, 2013). The baseline modeling simulation of a building includes building parameters such as insulation levels, mechanical systems and building orientations. Once energy use baseline is developed, the next step is to figure out what contributes to the energy use in a building. Most commercial buildings have similar set of energy end uses. Most common end uses in the commercial buildings are:

- Interior and exterior lighting

- $\quad$ Space heating and cooling

- Ventilation 
- Water heating

- $\quad$ Equipment (including office equipment)

- Cooking

- Refrigeration

A substantial portion of the building energy use is dedicated to the important function of thermal comfort. Passive architectural design and efficient building systems have dramatic impact on the thermal comfort and energy use. Many design options have been outlined by Hootman for a net zero building to meet energy target; however options related to the building geometry, envelope design, zoning and HVAC system design are focused in this project.

Building orientation is one of the most fundamentally important decisions for most net zero energy buildings, because passive strategies rely on access and utilization of the climate. From the climate perspective, orientation needs to respond to both sun and wind. Wind is variable but trends can be predicted. The path of the sun is definitively known, which can be used for daylight, solar radiation control, solar access for on-site photovoltaic and solar thermal systems. In the northern hemisphere, the sun follows a range of seasonal paths from the east to west in the southern sky. The summer has the highest sun angles, and the winter has the lowest.

Thermal zoning within a building refers to the strategic arrangement of spaces to take advantage of the thermal synergies and qualities of spaces, and their relationship to other spaces. There are two basic approaches to planning for thermal zones. The first is to consider the thermal requirements of a space in relation to the exterior. The second is to consider the thermal requirements to a space in relation to other spaces. From the activity type, identify the desired thermal condition of each space. Also identify the thermal loads of the space, based on use. From the climate analysis, identify the seasonal temperature ranges and solar radiation. These thermal conditions can be studied to determine optimal thermal zoning, to help reduce thermal transfer, create thermal buffers, and allow beneficial thermal transfer or storage. Some spaces have high internal heat gains, such as computer server rooms, data centres, mechanical rooms, and commercial kitchens. These high heat gain rooms can be located in the north perimeter for passive cooling, or can be source of heat for other areas having heating load. The heat can also be stored in an appropriate thermal storage space designed in the room. A thermal storage space is most effective when it is a remote thermal mass zone that is unoccupied and can store heat(in winter) for an extended period for use in other areas of the building and at various times. 
Phillip McKeen under the supervision of Dr. Alan Fung at Ryerson University performed building simulation of multi-unit residential buildings with the objective of determining the effect of aspect ratio on the energy efficiency of the buildings. Aspect ratio defines the envelope surface area through which heat is transferred between the atmosphere and indoor environment. Analysis revealed that changing the aspect ratio resulted in different surface area of envelopes for an equivalent floor area. Though the minimum surface area has been achieved by 1:1 aspect ratio, the desired aspect ratio has been obtained through the balance of heat loss and gain due to the presence of solar radiation on specific areas of the building at specific length of time. McKeen simulated a number of building using eQuest to determine a relationship between the building aspect ratio and energy efficiency. The simulation was also used to establish a relationship between building's orientation and energy efficiency.

Design parameters of the building were moderately above the ASHRAE 90.12007 requirements, and Toronto climate condition was used for simulation. Thirteen different aspect ratios were modeled with the longest sides first facing south and north, and then rotated $90^{\circ}$ so that the longest sides can face east and west. It can be seen in Table 7 that though the total floor area and the percentage of glazing are kept constant, the wall surface area, glazing area and south facing surface area changed with the change of aspect ratio and orientation.

Table 7: Different aspect ratio for simulation geometry (McKeen and Fung, 2014)

\begin{tabular}{|c|c|c|c|c|c|c|c|c|c|c|c|c|c|c|}
\hline $\begin{array}{r}\text { Building Profile: } \\
\text { Aspect Ratio (X:Y) }\end{array}$ & $\begin{array}{c}A \\
1: 1\end{array}$ & $\begin{array}{c}\text { B } \\
1.3: 1\end{array}$ & $\begin{array}{l}\mathrm{B} 90^{\circ} \theta \\
1: 1.3\end{array}$ & $\begin{array}{c}\mathrm{C} \\
1.5: 1\end{array}$ & $\begin{array}{l}\mathrm{C} 90^{\circ} \theta \\
1.5: 1\end{array}$ & $\begin{array}{c}\text { D } \\
2: 1\end{array}$ & $\begin{array}{c}\mathrm{D} 90^{\circ} \theta \\
1: 2\end{array}$ & $\begin{array}{c}\text { E } \\
2.7: 1\end{array}$ & $\begin{array}{l}\mathrm{E} 90^{\circ} \theta \\
1: 2.7\end{array}$ & $\begin{array}{c}\text { F } \\
3.2: 1\end{array}$ & $\begin{array}{l}\mathrm{F} 90^{\circ} \theta \\
1: 3.2\end{array}$ & $\begin{array}{c}\mathrm{G} \\
4.2: 1\end{array}$ & $\begin{array}{l}\mathrm{G} 90^{\circ} \mathrm{\theta} \\
1: 4.2\end{array}$ & \\
\hline Dimensions X & 24.5 & 28.0 & 21.4 & 30.0 & 20.0 & 35.0 & 17.1 & 40.0 & 15.0 & 44.0 & 13.6 & 50.0 & 12.0 & (m) \\
\hline Dimension $\mathrm{Y}$ & 24.5 & 21.4 & 28.0 & 20.0 & 30.0 & 17.1 & 35.0 & 15.0 & 40.0 & 13.6 & 44.0 & 12.0 & 50.0 & (m) \\
\hline Wall Surface Area & 2987 & \multicolumn{2}{|c|}{3011} & \multicolumn{2}{|c|}{3048} & \multicolumn{2}{|c|}{3176} & \multicolumn{2}{|c|}{3353} & \multicolumn{2}{|c|}{3511} & \multicolumn{2}{|c|}{3780} & $\left(\mathrm{~m}^{2}\right)$ \\
\hline $\begin{array}{r}\text { Glazing Area }(\% \text { of } \\
\text { exterior surface) }\end{array}$ & $36 \%$ & \multicolumn{2}{|c|}{$36 \%$} & \multicolumn{2}{|c|}{$36 \%$} & \multicolumn{2}{|c|}{$36 \%$} & \multicolumn{2}{|c|}{$36 \%$} & \multicolumn{2}{|c|}{$36 \%$} & \multicolumn{2}{|c|}{$36 \%$} & - \\
\hline Glazing Area & 1075 & \multicolumn{2}{|c|}{1084} & \multicolumn{2}{|c|}{1097} & \multicolumn{2}{|c|}{1143} & \multicolumn{2}{|c|}{1207} & \multicolumn{2}{|c|}{1264} & \multicolumn{2}{|c|}{1361} & $\left(\mathrm{~m}^{2}\right)$ \\
\hline $\begin{array}{r}\text { South Facing Surface } \\
\text { Area }\end{array}$ & 747 & 853 & 652 & 914 & 610 & 1067 & 521 & 1219 & 457 & 1341 & 415 & 1524 & 366 & $\left(\mathrm{~m}^{2}\right)$ \\
\hline $\begin{array}{l}\text { South Facing Surface } \\
\text { (\% of exterior surface) }\end{array}$ & $25 \%$ & $28 \%$ & $22 \%$ & $30 \%$ & $20 \%$ & $34 \%$ & $16 \%$ & $36 \%$ & $14 \%$ & $38 \%$ & $12 \%$ & $40 \%$ & $10 \%$ & - \\
\hline
\end{tabular}


For heating and cooling, all the buildings used four-pipe fan coil units with centrifugal hermetic chiller and natural gas boiler. The annual energy consumptions due to different aspect ratio are shown in Table 8.

Table 8: Annual energy consumption for different aspect ratio (McKeen and Fung, 2014)

\begin{tabular}{|c|c|c|c|c|c|c|c|c|c|c|c|c|c|c|}
\hline $\begin{array}{l}\text { Aspect Ratio (x:y) } \\
\text { Building Profile: }\end{array}$ & $\begin{array}{l}1: 4.2 \\
\mathrm{G} 90^{\circ} \theta\end{array}$ & $\begin{array}{l}1: 3.2 \\
\text { F } 90^{\circ} \theta\end{array}$ & $\begin{array}{l}1: 2.7 \\
\mathrm{E} 90^{\circ} \mathrm{B}\end{array}$ & $\begin{array}{c}1: 2 \\
\mathrm{D} 90^{\circ} \theta\end{array}$ & $\begin{array}{l}1.5: 1 \\
\mathrm{C} 90^{\circ} \mathrm{\theta}\end{array}$ & $\begin{array}{l}1: 1.3 \\
\text { B } 90^{\circ} \theta \\
\end{array}$ & $\begin{array}{l}1: 1 \\
\text { A }\end{array}$ & $\begin{array}{c}1.3: 1 \\
\mathbf{B}\end{array}$ & $\begin{array}{c}1.5: 1 \\
\mathrm{C}\end{array}$ & $\begin{array}{c}2: 1 \\
\text { D }\end{array}$ & $\begin{array}{c}2.7: 1 \\
\mathbf{E}\end{array}$ & $\begin{array}{c}3.2: 1 \\
\mathbf{F}\end{array}$ & $\begin{array}{c}4.2: 1 \\
\mathrm{G}\end{array}$ & \\
\hline \multicolumn{15}{|c|}{ Toronto } \\
\hline \multirow[t]{2}{*}{ Cooling Consumption } & 116.9 & 111.5 & 104.1 & 99.9 & 96.0 & 93.6 & 92.9 & 91.9 & 91.0 & 90.5 & 89.4 & 913 & 91.1 & $(\mathrm{MWh})$ \\
\hline & 421.0 & 401.2 & 374.8 & 359.8 & 345.8 & 337.1 & 334.6 & 330.7 & 327.5 & 325.9 & 321.7 & 328.5 & 328.1 & (GJ) \\
\hline Heating Consumption & 1428 & 1303 & 1230 & 1157 & 1087 & 1063 & 1056 & 1048 & 1054 & 1100 & 1143 & 1211 & 1308 & (GJ) \\
\hline REC & $35.2 \%$ & $23.4 \%$ & $16.5 \%$ & $9.6 \%$ & $3.0 \%$ & $0.7 \%$ & $0.0 \%$ & $-0.8 \%$ & $-0.2 \%$ & $4.1 \%$ & $8.2 \%$ & $14.7 \%$ & $23.9 \%$ & \\
\hline $\begin{array}{r}\text { Combined Energy } \\
\text { Consumption }\end{array}$ & 1849 & 1705 & 1604 & 1517 & 1433 & 1400 & 1391 & 1378 & 1381 & 1425 & 1464 & 1540 & 1636 & (GJ) \\
\hline REC & $33.0 \%$ & $22.6 \%$ & $15.4 \%$ & $9.1 \%$ & $3.0 \%$ & $0.7 \%$ & $0.0 \%$ & $-0.9 \%$ & $-0.6 \%$ & $2.5 \%$ & $5.3 \%$ & $10.7 \%$ & $17.6 \%$ & \\
\hline
\end{tabular}

It is noticed from the analysis that the most energy efficient aspect ratio are 1:1, 1.3:1 and 1.5:1. Further elongation of the building in the east-west or north-south direction results in abrupt increase in both heating and cooling energy consumption.

\subsection{Design of Typical Water Source Heat Pump Systems}

This part of the literature review will examine design criteria of typical water source heat-pump systems used in the commercial buildings. Careful examinational of the existing designs may help to innovate ways of designing a two pipe distributive system, which will operate without any external heating or cooling equipment conventionally connected to the loop. The design guides have been developed by design professionals and leading equipment manufacturers.

\subsubsection{Daikin McQuay Inc Design Guide}

Water source heat pump design capitalizes on the diversity factor in heating and cooling load of any building. It is unrealistic to think that all the heat gain factors happening during the peak cooling hours in a large commercial building. Same thing can be said about the heating load. Load level in different zones can also vary. At a certain hour some zones may require higher 
cooling and heating than others, while the latter zones may require higher cooling and heating at a different time of the day. Central heating and cooling systems have poor part-load efficiencies, and maintaining individual zone temperature is also proven difficult (McQuay Inc., 1999). With central heating and cooling systems it is common to supply both heated and cooled air in a single zone to maintain the required zone temperature. This concept can waste a lot of energy during part load condition, which happens during the most part of the year. Water source heat pumps provide the flexibility to have individual unit at each zone, operated by individual thermostat and providing either heating or cooling. Terminal water source heat pumps connected in one closed loop also allows efficient transfer of energy from the satisfied areas of the building to the areas lacking sufficient energy.

Water-source heat pump is a decentralized system that provides heating and cooling throughout the year using a two pipe system. The system circulates non-refrigerated water from which heatpumps either extract heat for cooling or to which the heat pumps reject heat from the zones for cooling. This system achieves energy efficiency by transferring heat from the warm zones to the cold zones when they coexist. System is designed to maintain the loop temperature between 65 ${ }^{\circ} \mathrm{F}$ to $95^{\circ} \mathrm{F}\left(18.3{ }^{\circ} \mathrm{C}\right.$ to $\left.35^{\circ} \mathrm{C}\right)$ (McQuay Inc., 1999). In a conventional system supplemental heat adding equipment such as a condensing boiler and a heat rejection equipment such as a cooling tower is added in order to add heat at the lower end of the rage and reject heat at the higher end of the range respectively. Figure 14 to Figure 17 show four possible configurations of water source heat pumps suggested by McQuay Inc. for different load conditions. 


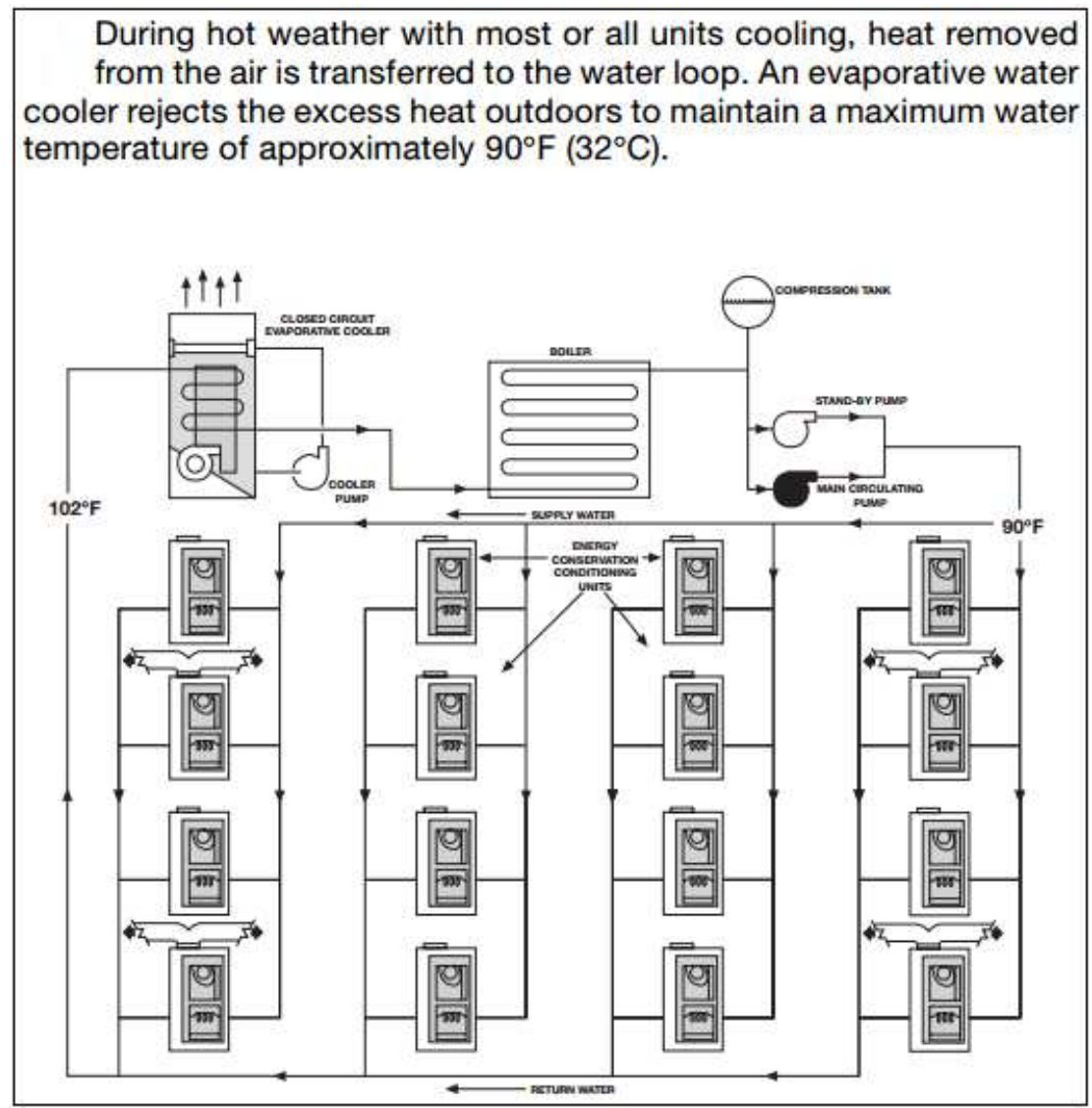

Figure 14: Configuration of conventional water-source heat pump system during cooling only operation (McQuay Inc., 1999) 


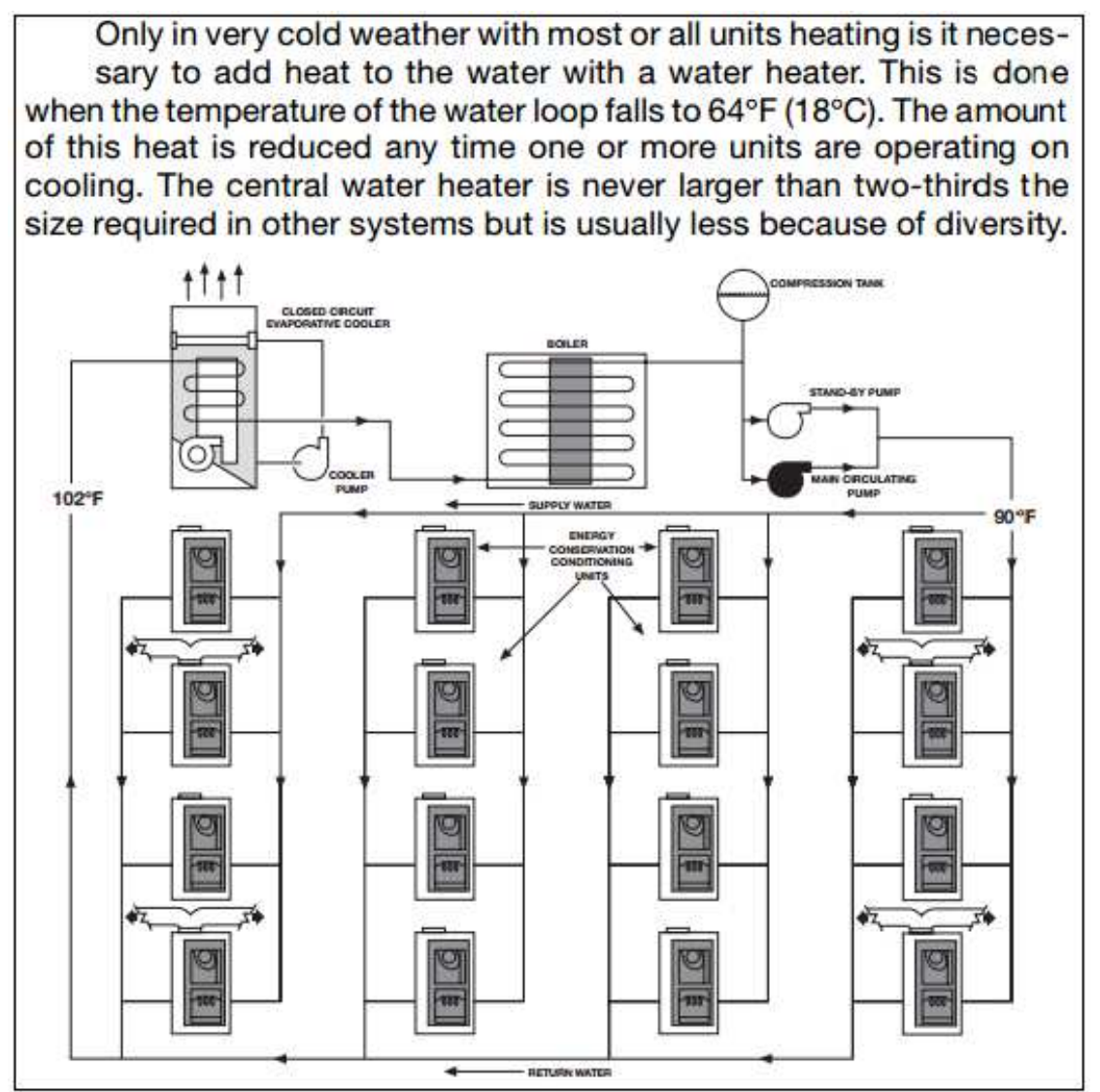

Figure 15: Configuration of conventional water-source heat pump system during mainly heating operation (McQuay Inc., 1999) 


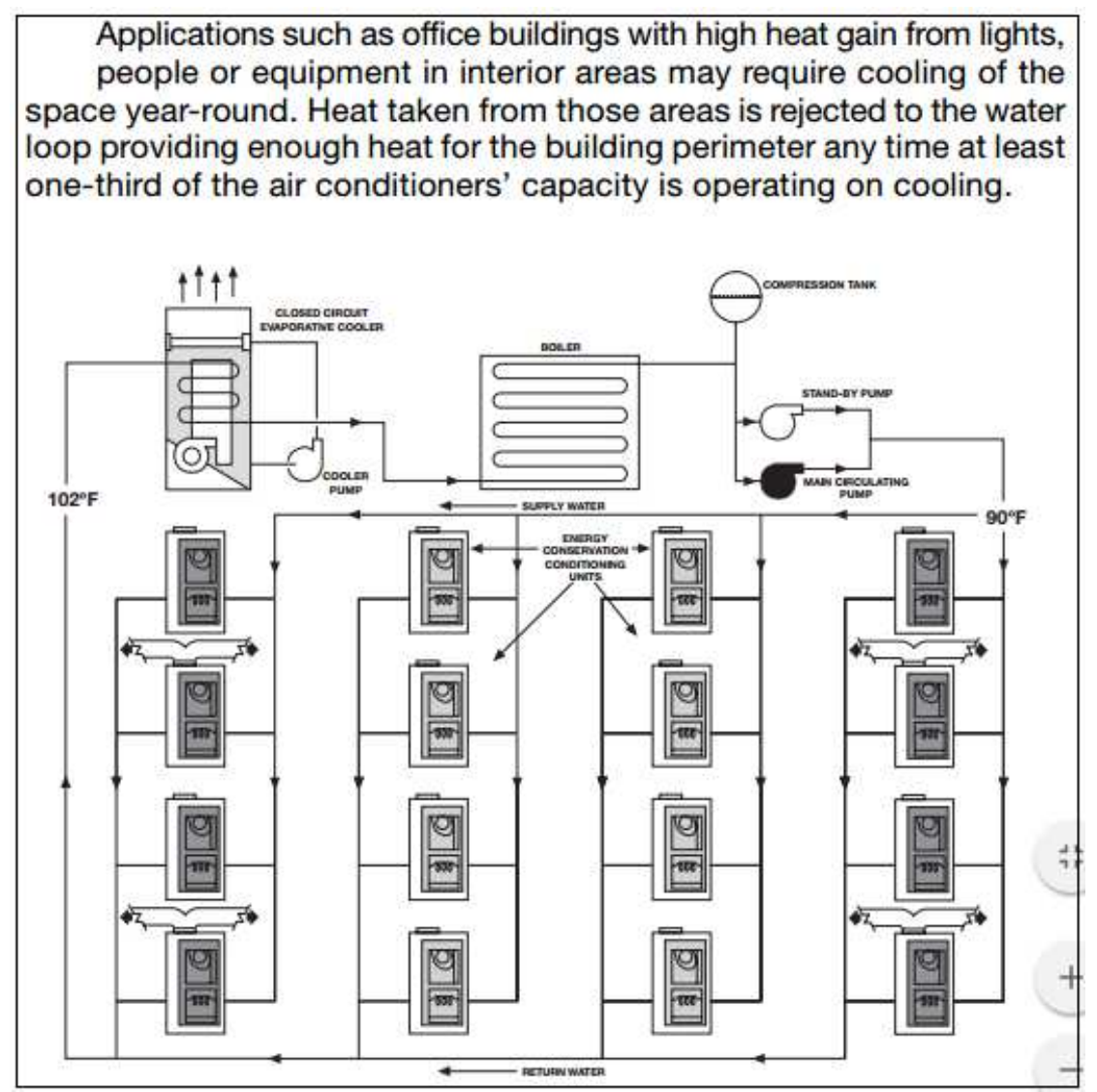

Figure 16: Configuration of conventional water-source heat pump system in buildings with high internal heat gain (McQuay Inc., 1999) 


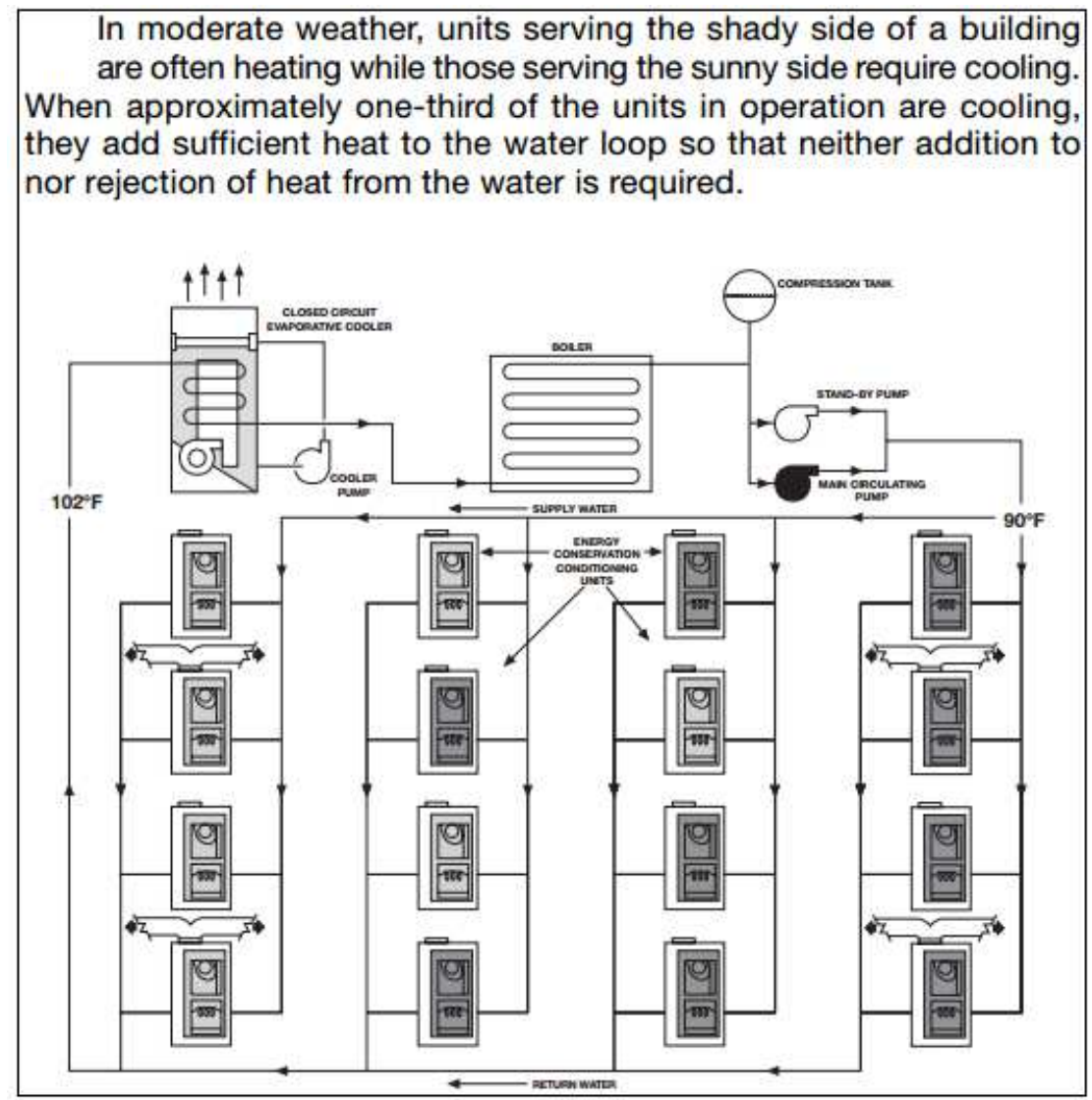

Figure 17: Configuration of conventional water-source heat pump system during simultaneous heating and cooling loads (McQuay Inc., 1999)

Energy storage tanks can be used for energy conservation. A low temperature storage tank can conserve energy by storing surplus heat produced in the building core during the day and acting as a heat source by supplying the stored heat at night to for heating. A low temperature storage tank typically uses water in a tank. It can potentially eliminate use of a cooling tower in winter and shoulder season for rejection of any surplus heat. However, a cooling tower or a dry cooling is still necessary in the summer season for rejecting heat when the stored energy in the storage tank is no longer used for heating during the night time. Once surplus heat is rejected in the storage tank, its temperature can be raised up to $140^{\circ} \mathrm{F}\left(60^{\circ} \mathrm{C}\right)$ using water to water heat pump (McQuay Inc., 1999). The tank is piped parallel to the evaporative or dry cooler. When loop temperature is above the set range, loop water is diverted to the storage tank, where excess heat is rejected. This process continues until the storage tank reaches its highest temperature. At night time, when loop temperature becomes colder than the storage tank, the storage medium 
rejects heat to the loop, which is then used by the heat pumps as heat source to provide energy to the areas in the need of cooling. Figure 18 is a typical schematic for a heat pump system that uses heat storage.

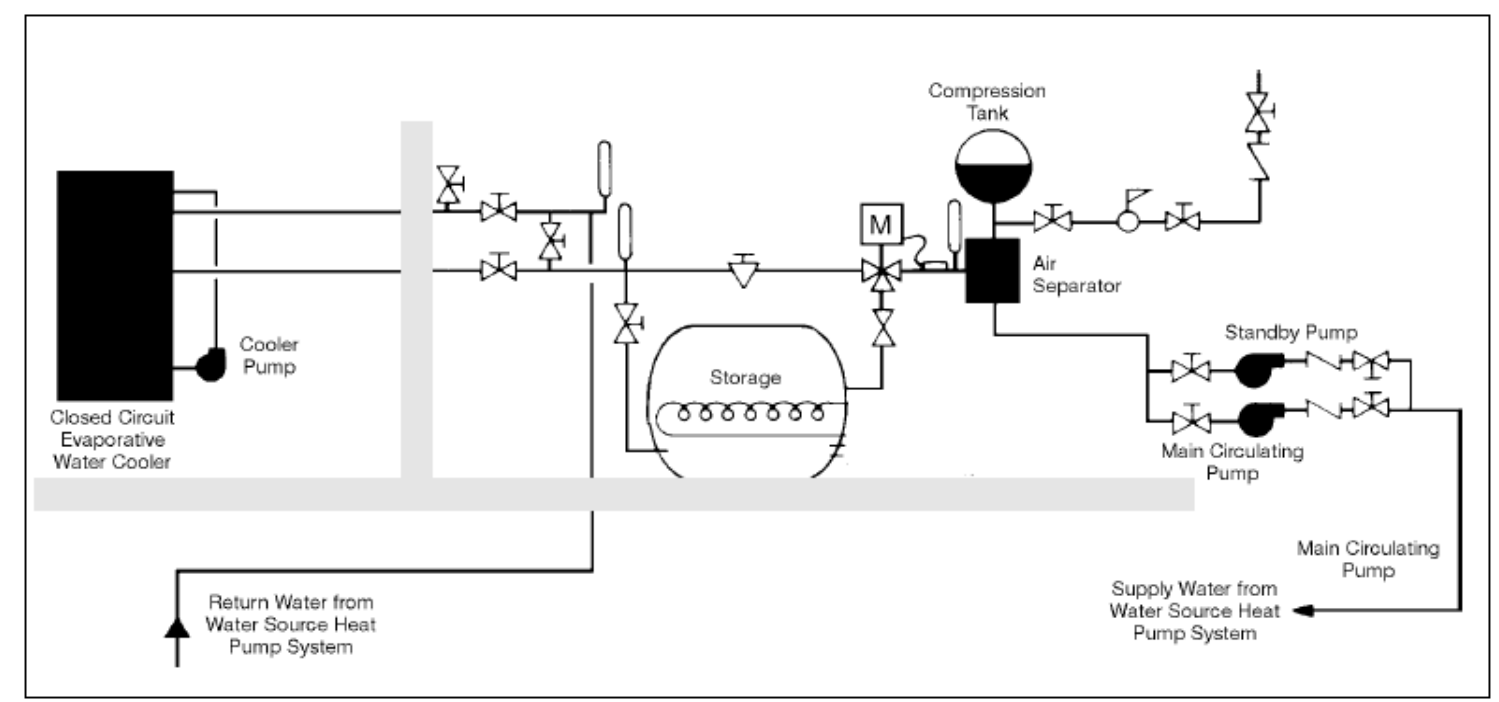

Figure 18: Heat pump system using heat storage tank (McQuay Inc., 1999)

The concept heat of heat pump system with heat storage and water-to-water heat pump is shown in Appendix A.

Water Loop Temperature Control: Water loop temperature is generally maintained between a minimum of $65^{\circ} \mathrm{F}\left(18.3{ }^{\circ} \mathrm{C}\right)$ in winter and a maximum of $95^{\circ} \mathrm{F}\left(35^{\circ} \mathrm{C}\right)$ in the summer for optimal system operation by the building automation system (BAS) (Daikin McQuay Inc.). The control should start to reject heat in response to a temperature rise above $85^{\circ} \mathrm{F}\left(29.4{ }^{\circ} \mathrm{C}\right)$ and achieve full capacity at $94{ }^{\circ} \mathrm{F}\left(34.4^{\circ} \mathrm{C}\right)$. The controls should initiate addition of supplementary heat addition to the water loop when the loop temperature drops $67^{\circ} \mathrm{F}\left(19.4^{\circ} \mathrm{C}\right)($ McQuay Inc., 1999)

Space temperature control for heat pumps includes low voltage wall thermostat. Typically one thermostat controls one heat pump; however for larger zones, two or more heat pumps can provide heating or cooling, and can be controlled by one thermostat. Night setback can substantially reduce the energy consumed by the HVAC system. Night setback can provide the following:

1) Restart all conditioners after a general shutdown, from a central point, when so 
desired.

2) Stop all air conditioners from the same central point when desired.

3) Keep all electric circuits to the HVAC system energized at all times, to maintain a minimum conditioned space temperature at night time setting.

4) For systems with fans, cycle fans during night shut down period.

5) Switch ventilation systems off, and switch corridor lighting to night requirements.

6) Perimeter units can provide minimum space temperature control during the night setback.

Generally thermostats have a night temperature sensor set to control the heat pumps at $60^{\circ} \mathrm{F}$ $\left(15.6{ }^{\circ} \mathrm{C}\right)$ (McQuay Inc., 1999). During the morning pull-up period, most of the terminal units operate in the same mode. In winter, the perimeter units operate in the heating mode, while interior zones units are off. In summer, all units operate in the cooling mode. Through the provision of the energy storage tanks, a low temperature tank stores day surplus heat energy for overnight use.

\subsubsection{Thermal Performance of Water Source Heat Pumps}

Liu et al performed testing and analysis of typical water source heat pump system to establish thermal performance in the winter conditions. Testing and analysis were performed to assess energy efficiency indicator of the water source heat pump system. The following equations were used to calculate energy efficiency of the water source heat pump unit itself $\left(\mathrm{EER}_{\mathrm{HP}}\right)$ and the whole system $\left(\mathrm{EER}_{\text {system }}\right)$ :

$$
\begin{aligned}
& \mathrm{EER}_{\mathrm{HP}}=\mathrm{Q}_{\text {cap }} / \mathrm{W}_{\text {comp }} \\
& \mathrm{EER}_{\text {system }}=\mathrm{Q}_{\text {sh }} / \mathrm{W}_{\text {input }}
\end{aligned}
$$

Here $\mathrm{Q}_{\text {cap }}$ is heating produced by the heat pump

$Q_{\text {sh is }}$ the space actual heating load

$\mathrm{W}_{\text {comp }}$ is the power input to the compressor

$\mathrm{W}_{\text {input }}$ is the total power input to the system

Test result shows that the heat pump system was able to maintain indoor average temperature at $73.76^{\circ} \mathrm{F}\left(23.2^{\circ} \mathrm{C}\right)$ for a 24 hour period though the outdoor temperature changed from $50^{\circ} \mathrm{F}(10$ $\left.{ }^{\circ} \mathrm{C}\right)$ to $32{ }^{\circ} \mathrm{F}\left(0^{\circ} \mathrm{C}\right)$ (Liu et al, 2011). 
From the monitoring data of the heat pump system, it was noticed that the average temperature of water in the supply side of the source water is $13.20^{\circ} \mathrm{C}\left(55.76{ }^{\circ} \mathrm{F}\right)$ and the return water temperature is $10.32{ }^{\circ} \mathrm{C}\left(50.58{ }^{\circ} \mathrm{F}\right)$ ( $\mathrm{Liu}$ et al, 2011). Figure 19 shows supply and return temperature of the source water at different times in 24 hours period.

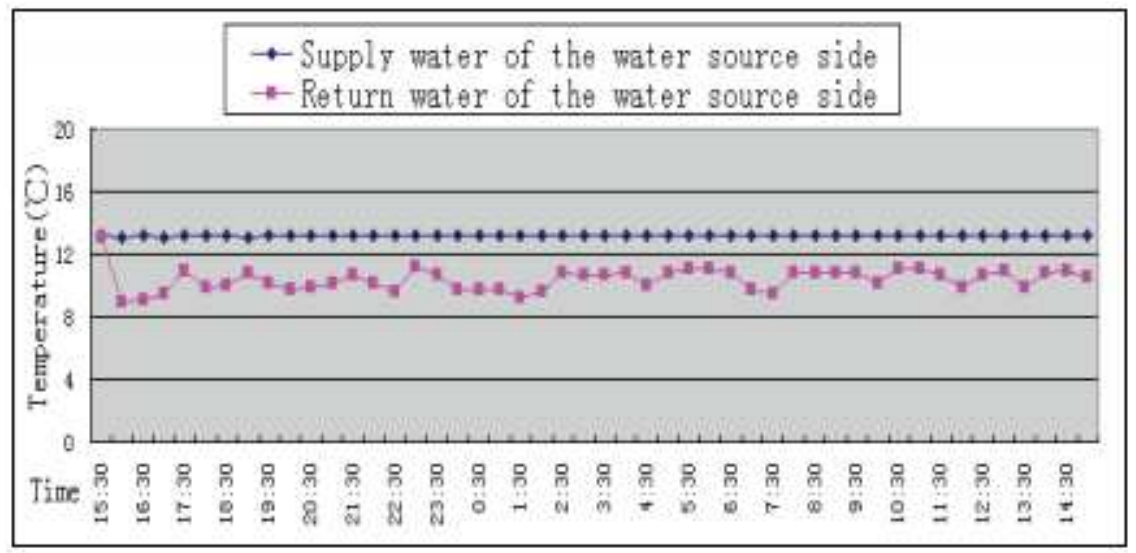

Figure 19: Source water temperature at supply and return sides of the heat pump (Liu et al, 2011)

At this design condition, the heat pump average efficiency (COP) is 3.12 , whereas the rated nameplate COP is 3.51. It is suggested that the unit was operating at partial load, which caused the inefficiency. It is also suggested that the loop temperature should be increased to increase the efficiency of the heat pump (Liu et al, 2011).

2.5.3. Thermodynamic Performance Analysis of Water Source Heat Pump in Various Operating Condition

This study at the North China Electric Power University used the principal of the first law of thermodynamics to analyze performance of water source (water-to-water) heat pumps at variant operating conditions. It also suggests design and operation of water source heat pumps. Water source heat pumps usually work in off-design condition, under which the performance is different from what is rated in the equipment catalogue. The authors of this study selected a certain brand of water source heat pump with rated refrigerating capacity of 3,378 kBtu/h (990 $\mathrm{kW})$, input power of $623.74 \mathrm{kBtu} / \mathrm{h}(182.8 \mathrm{~kW})$, water flow of the condenser $396 \mathrm{gpm}(90.1$ $\left.\mathrm{m}_{3} / \mathrm{h}\right)$ and water flow of the evaporator $170.7 \mathrm{~m}_{3} / \mathrm{h}(751 \mathrm{gpm})$. In the heating condition, the 
heating output is $3,619 \mathrm{kBtu} / \mathrm{h}(1058 \mathrm{~kW})$, input power is $810.72 \mathrm{kBtu} / \mathrm{h}(237.6 \mathrm{~kW})$, water flow of the condenser is $835.56 \mathrm{gpm}\left(189.9 \mathrm{~m}_{3} / \mathrm{h}\right)$, and water flow of evaporator is $390.28 \mathrm{gpm}(88.7$ $\mathrm{m}^{3} / \mathrm{h}$ ). Table 9 and table 10 show coefficient of performance (COP) at varying operating condition during cooling and heating operation of the water source heat pump.

Table 9: Cooling COP of water source heat pump in various operating condition

\begin{tabular}{|c|c|c|c|c|c|}
\hline \multirow{2}{*}{$\begin{array}{l}\text { Inlet/outlet } \\
\text { temperature } \\
\text { Of chilked water( }(1))\end{array}$} & \multicolumn{5}{|c|}{ Inlet/outlet temperature of coolin water $\left({ }^{\circ} \mathrm{C}\right)$} \\
\hline & $10 / 21$ & $14 / 25$ & $18 / 29$ & $21 / 32$ & $25 / 36$ \\
\hline $10 / 5$ & 5.83698 & 5.302927 & 5.084178 & 4.634636 & 4.302235 \\
\hline $12 / 7$ & 6.248948 & 5.694918 & 5.415755 & 4.904835 & 4.578775 \\
\hline $14 / 9$ & 6.65196 & 6.017505 & 5.681233 & 5.165026 & 4.703156 \\
\hline $16 / 11$ & 6.988071 & 6.273696 & 5.988575 & 5.464989 & 4.902192 \\
\hline $18 / 13$ & & 6.477668 & 6.189434 & 5.65753 & 5.00616 \\
\hline $20 / 15$ & & 6.572518 & 6.335411 & 5.942952 & 5.190098 \\
\hline
\end{tabular}

Table 10: Heating COP of water source heat pump in various operating condition

\begin{tabular}{|l|l|l|l|l|}
\hline $\begin{array}{l}\text { Inlet/outlet } \\
\text { Temperature } \\
\text { Of chitled water( }(0)\end{array}$ & $40 / 45$ & $43 / 48$ & $45 / 50$ & $47 / 52$ \\
\cline { 2 - 5 } & & & & \\
\hline $13 / 5$ & 4.317927 & 4.024702 & 3.870245 & 3.657708 \\
\hline $15 / 7$ & 4.452862 & 4.116797 & 3.962639 & 3.822368 \\
\hline $19 / 11$ & 4.629213 & 4.326838 & 4.166898 & 3.940586 \\
\hline $21 / 13$ & 4.849652 & 4.494477 & 4.33142 & 4.104377 \\
\hline $23 / 15$ & 5.020384 & 4.66094 & 4.493343 & 4.222542 \\
\hline & 5.238661 & 4.865164 & 4.653441 & 4.303186 \\
\hline
\end{tabular}

It is evident that for cooling condition in summer, COP increases as the outlet temperature of the chilled water increases, and reduces as the inlet temperature of the cooling water increases. The outlet temperature of the chilled water can be properly increased and the inlet temperature of the cooling water can be properly decreased to reduce energy consumption (Zheng and Jing 2009).

In the winter operation, COP increases as the outlet temperature of the chilled water increases, and reduces as the inlet temperature of the cooling water increases (Zheng and Jing 2009). 
For the intended common loop water source heat pump system it is expected that there will be cooling load in the core zones of the office building during the winter and shoulder season, whereas heating load is expected in the perimeter zones. Thus, a common loop temperature shall be selected to maximize the COP of both the heat pumps operating in the heating mode and the heat pumps in the cooling mode (Zheng and Jing 2009).

\subsection{Energy Conservation Using Closed Loop Heat Pump in Commercial Office Building}

This paper discusses the applicability of common loop water source heat pumps in buildings, where simultaneous heating and cooling loads occur. This was examined by modelling and simulation using software. The internally generated heat is used to meet heating load before use of any external source, using the closed water room as a transport system to move heat energy from where is extracted to where it is needed. The paper also discusses the option of using thermal storage to store heat for later use. The paper reports the result of a study on the effect of component arrangement and system control strategy on the energy saving potential of the water loop heat pump used for heating and cooling of a commercial office building.

The water loop heat pump system design is similar to that of a four pipe fan coil system. Each perimeter zone is served by individual heat pumps, while the cores zones are served by a central air handling unit. In a typical winter day the perimeter zones normally require heating while the core zones require cooling because of human occupancy, lighting and equipment. The closed loop water first passes through the core zones, where the heat pump rejects extracted heat into the water loop. The heated water then passed through perimeter zones, where the heat is introduced by the heat pump.

This concept was simulated for both series circuit and parallel circuit concepts. For the series circuit configuration during the experimental simulation it was observed that during the summer days the exhaust water temperature core zones reached as high as $93{ }^{\circ} \mathrm{C}\left(200{ }^{\circ} \mathrm{F}\right)$. When this water was passed to the perimeter zones, which also needs cooling, the heat pumps worked very inefficiently. In such case the heated water will need to go through a cooling tower capable of bringing the water temperature down to a temperature that provides minimum cooling $\mathrm{COP}$ of the perimeter heat pumps. In winter the heated water will travel to the perimeter heat pumps directly without going through the cooling tower. 
In the parallel configuration, water will be allowed to both core zone and perimeter zones at the same time during the summer months, thus allow the perimeter and core zone to receive water at the same temperature. During the winter the water flow will go through the core zones first and then the perimeter zones.

The building that was modelled under this study is a two storey building located in St. Louis, Missouri, which has a cold winter with record coldest temperature of $-23{ }^{\circ} \mathrm{C}\left(-9.4{ }^{\circ} \mathrm{F}\right)$. Modelling parameters of the building are shown in Table 11:

Table 11: Modelling parameters of the commercial office building (Rao and Harry, 2009)

\begin{tabular}{|c|c|}
\hline Building roof area & 22,810 sq.ft. (2119 sq.m.) \\
\hline Building floor area & 45,620 sq.ft. (4238 sq.m) \\
\hline Building exterior wall & 9,460 sq.ft. (879 sq.m) \\
\hline Fenestration glass area & 7,536 sq.ft. (700 sq.m.) \\
\hline Internal load density in each zone & $2.9 \mathrm{~W} / \mathrm{sq} . \mathrm{ft}$ (31 W/sq.m.) \\
\hline Total occupancy & 408 People \\
\hline Ceiling height & $8.5 \mathrm{ft}(2.59 \mathrm{~m})$ \\
\hline Roof U-factor & $0.25 \mathrm{Btu} / \mathrm{hr} . \mathrm{sq} . \mathrm{ft} .{ }^{\circ} \mathrm{F}\left(0.79 \mathrm{~W} / \mathrm{sq} . \mathrm{m} .{ }^{\circ} \mathrm{C}\right)$ \\
\hline Exterior wall U-factor & $0.2 \mathrm{Btu} / \mathrm{hr} . \mathrm{sq} . \mathrm{ft} .{ }^{\circ} \mathrm{F}\left(0.63 \mathrm{~W} / \mathrm{sq} . \mathrm{m} .{ }^{\circ} \mathrm{C}\right)$ \\
\hline Glass U-factor & 1 Btu/hr.sq.ft. ${ }^{\circ} \mathrm{F}\left(3.15\right.$ W/sq.m. $\left.{ }^{\circ} \mathrm{C}\right)$ \\
\hline Shading coefficient & 0.6 \\
\hline Interior setpoint temperature & $75^{\circ} \mathrm{F}\left(23.9^{\circ} \mathrm{C}\right)$ \\
\hline Relative humidity & $50 \%$ \\
\hline Building thermal mass & Medium \\
\hline Building operation & 24 hours \\
\hline
\end{tabular}

The building was modelled in multiple states. After simulating the building with energy storage, it was found that there is a large drop in auxiliary heating energy consumption in St. Louis and Minneapolis, which have very cold winters (Rao and Harry, 2009). The energy saving has not been quantified in the report. 


\subsection{Optimizing Water Loop Temperature}

Selecting the optimized temperature was part of a study performed by the University of Nebraska-Lincoln on the control strategy of water loop heat pump system. It is stated that generally the conventional heat pump loop temperature is maintained between $60^{\circ} \mathrm{F}$ lower limit and $90{ }^{\circ} \mathrm{F}$ upper limit; heating boiler and cooling tower are programmed to this temperature range (Lian, 2011). Generally no measure is taken in the loop temperature is floating in this range. From a parametric analysis to find out the optimal supply temperature for the water source heat pump system, it has been found that the heat pump performance is more sensitive to the loop supply water temperature in the cooling mode than in the heating mode. By gather data from a heat pump manufacturer, it was found that the cooling energy efficiency ratio (EER) increases from 11 to 20 when the loop supply temperature decreases from $85^{\circ} \mathrm{F}$ to $50^{\circ} \mathrm{F}$, and the heating EER increases from 17 to 19.5 when the supply temperature increases from $50{ }^{\circ} \mathrm{F}$ to 85 ${ }^{\circ} \mathrm{F}$. Based on a mathematical model, Lian concluded that the water source heat pump system is most suitable for buildings that have interior cooling load ratio of 0.3 or higher. It is also concluded that during the heating season, the supply water temperature should be maintained as high as possible to improve the heat pump efficiency. Lian suggested that the temperature of water at the inlet of the heat pumps must be $50^{\circ} \mathrm{F}$ or higher to ensure safety (Lian, 2011).

\subsection{Office building-Heat recovery using water source heat pumps}

This case study has been taken from ASHRAE Journal, published in December, 2014. The project of Jonxion-4905 Lapiniere is an 117,918 sq.ft. (10,955 sq.m.) office building near Montreal, and uses heat recovery from distributed common loop heat pump system without any external energy sources. Its energy consumption is only $9.7 \mathrm{kWh} / \mathrm{ft}^{2}\left(104 \mathrm{kWh} / \mathrm{m}^{2}\right)$ annually comparing to the Canadian office building average energy consumption of $31 \mathrm{kWh} / \mathrm{ft}^{2}$ (333 $\mathrm{kWh} / \mathrm{m}^{2}$ ) annually (Lussier, 2014).

Building envelope design was very crucial to balance the cooling and heating load so that the entire building and the fresh air supply can be heated by the recovered air and energy stored in the ground. Windows that are floor to ceiling are triple paned to limit the heat loss and heat gain in the perimeter areas. Windows that are $5 \mathrm{ft}$. high or less are double paned, low-e with argon 
gas space. This architectural character of the building helped to minimize the perimeter heat loss so that heat rejection from the interior space can be sufficient for the perimeter heating.

The heat pump system for the building is located in the roof penthouse. Each floor has a secondary ventilation system. There is a dedicated outdoor air system (DOAS) on the roof that supplies $16,000 \mathrm{cfm}(7551 \mathrm{~L} / \mathrm{s})$ of tempered fresh air to the secondary units, which also draws return air proportionally from the zones. The DOAS is equipped with an Energy Recovery wheel, which recovers heat and moisture from the exhaust air to pre-heat and humidify the fresh air introduced to the secondary units. There are six fan coil units to provide heating or cooling to the perimeter zones of the building. Heating and cooling to the fan coil units is provided by the central heat pump systems. Since the fan coils offset the heat loss/gain in the perimeter, the internal zones do not loose/gain heat to/from the outdoor environment; thus there is a sizable and consistent cooling load in the internal space generated from people, equipment, lighting etc.

The design incorporates two 80 ton $(281 \mathrm{~kW})$ centralized chillers, which act as heat pumps in the winter. Heat is removed from the interior zones by the chiller evaporators and transferred to the perimeter zones by the chiller condensers. The chiller evaporators operate $48{ }^{\circ} \mathrm{F}\left(9^{\circ} \mathrm{C}\right)$ and condensers operate at $95{ }^{\circ} \mathrm{F}\left(35^{\circ} \mathrm{C}\right)$, which results in a lower $\mathrm{kW} /$ ton. If the heat gain from the internal zones is not sufficient to heat the perimeters, the chillers extract energy from the ground using 28 geothermal closed loop vertical boreholes at $500 \mathrm{ft}(152 \mathrm{~m})$ deep. Heating coils are selected to use low temperature water allowing the chiller condenser water to provide heating without use of a boiler.

The distributed loop provides cooling to the interior space through the secondary ventilator. While the airflow from the secondary units is varied based on space load minimum fresh air supplied by the DOAS is set by ASHRAE 62.1 requirement. The fan coil units either cool or heat the perimeter zone based on the demand. All fans are equipped with variable frequency drives. Every coil is connected to the cooling and heating water loops and switches on the appropriate loop using automatic control three-way valves. All pumps are variable speed and modulate flow based on demand.

Both chilled and heated water are produced using two 80 ton $(281 \mathrm{~kW})$ high efficiency twin 
screw compressor chillers. After one year of operation, it was observed that only one chiller is needed and it operates at $60 \%$ part load (48 ton). At this operation point, the chiller's energy consumption is about $0.65 \mathrm{~kW} /$ ton (Lussier, 2014). During the cooling season, when both perimeter and the interior zones are in need of cooling, the chillers extract heat from the building and then reject to the ground via the closed ground loops. Figure 20 shows schematic of the air system as well as the common loop heat recovery system.

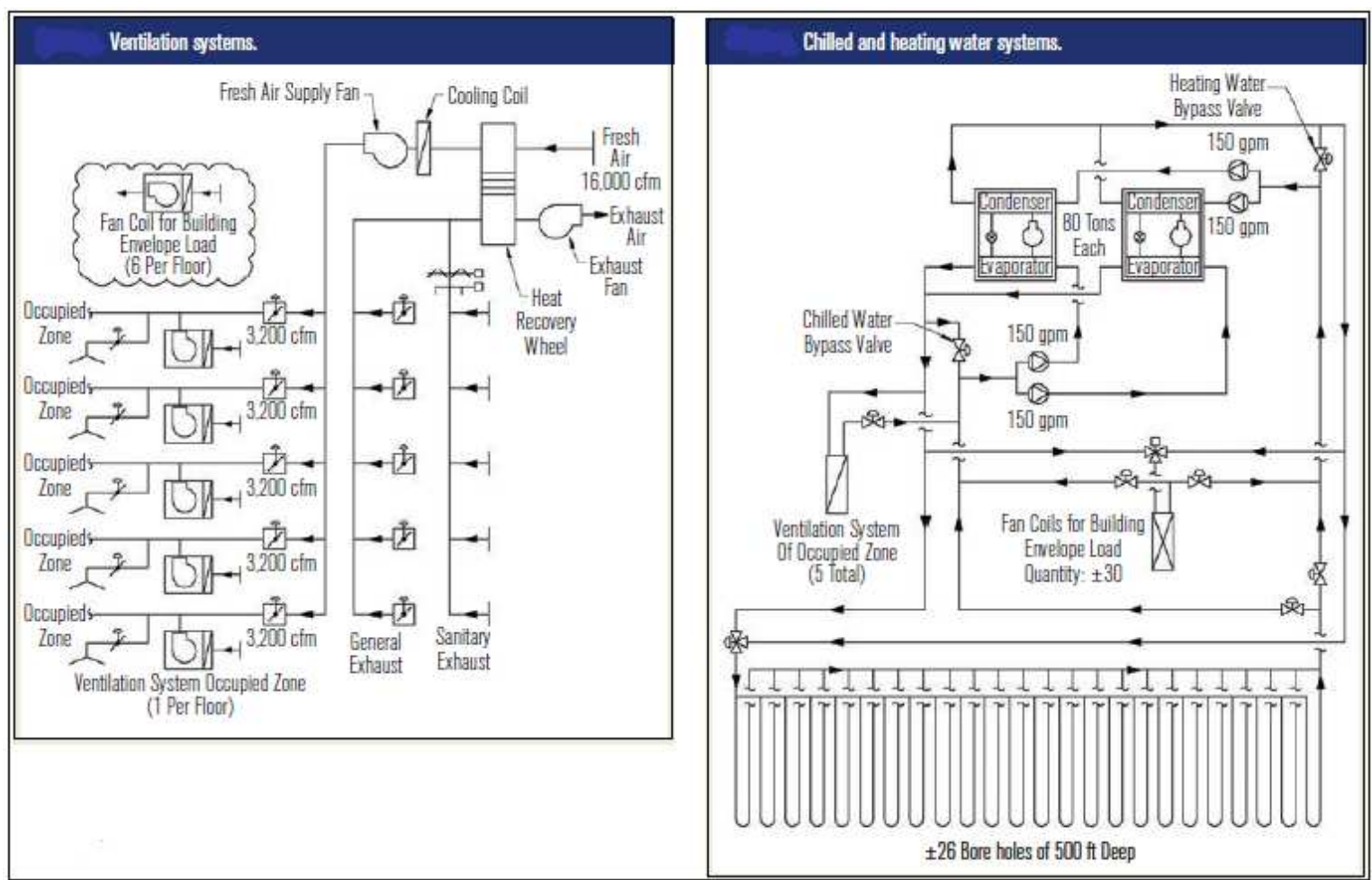

Figure 20: Schematic for ventilation, heating and cooling system (Lussier, 2014)

Energy performance of the building was modeled prior to the construction, and then actual energy consumption for one year was measured at 70\% average occupancy level. Figure 21 compares model energy consumption with the actual energy consumption after one year of operation. 


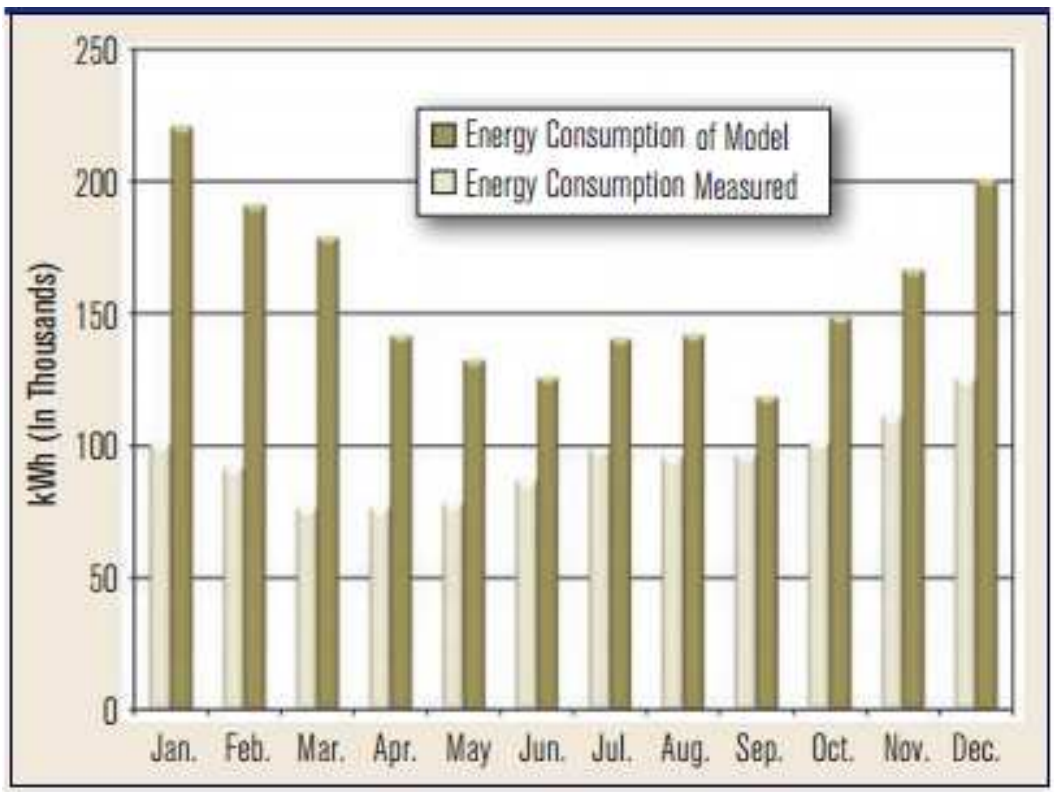

Figure 21: Modeled vs. actual energy consumption data (Lussier, 2014)

The actual total energy consumption for the year was $1,141,800 \mathrm{kWh}$, which translates to 9.7 $\mathrm{kWh} / \mathrm{ft}^{2}\left(104 \mathrm{kWh} / \mathrm{m}^{2}\right)$, whereas the model energy consumption of the model was $1,906,400$ $\mathrm{kWh}$ per year, which translates to $16 \mathrm{kWh} / \mathrm{ft}^{2}\left(172 \mathrm{kWh} / \mathrm{m}^{2}\right)$ per year. The actual annual energy consumption is $60 \%$ of the modeled energy consumption (Lussier, 2014). 


\subsection{Objective and Methodology}

The simulation and analysis of this project is done in two parts. The first part will be modelling of a typical commercial office building in Toronto. Heating and cooling of this building will be provided by four pipe fan coil system served by centrifugal chiller and natural gas boiler. All parameters of the base case will be based on the minimum energy efficiency standard of ASHRAE 90.1. Simulation of the base model will produce the following:

- Building peak heating and cooling load (without HVAC)

- Space heating and cooling load summary. This will be used for sizing the zone heat pumps.

- Building peak heating and cooling load components.

- Building monthly and annual load summary.

- Building annual energy consumption for heating, cooling, lighting and internal equipment

- Building monthly energy consumption for heating, cooling, lighting and internal equipment.

The second part will be modelling and analysis of the same building using distributed common loop water source heat pump system. It is expected that there will be cooling load in the core zones during the winter and shoulder seasons, when heating load will exist in the perimeter zones. Heat pumps in the core zones will raise the temperature of the water loop, which will act as heat sink; the hotter water will then be used as heat source for the heat pumps in the perimeter to provide heating. The heat pump loop will be connected to a cooling tower and a condensing boiler to reject excess heat or add heat during the winter to maintain the loop at a predetermined temperature range. Peak heating and cooling load data, as well as the annual energy consumption from this model will be compared against the base case.

Once the proposed model energy consumption is determined using distributed loop water source heat pump system, a sensitivity analysis will be performed to investigate the energy saving potential by changing the common loop temperature. 
4.0 Modelling and simulation

\subsection{The Base Case}

The base building is located in Toronto and designed to meet minimum design requirements of ASHRAE 90.1, which has been previously defined in section 1.6. It is a three storey building with a total area of 60,000 sq.ft. used for commercial office, which has private offices and board rooms along the perimeter, and open space in corridor with workstations and cubicles. The occupant density follows ASHRAE 62.1 standard for indoor air quality for buildings. Electricity rate has been taken from Toronto Hydro's time of use rate for commercial building, and the gas rate has been taken from Ontario Energy Board (rates have been shown in Table 13, 13A and 14). In order to utilize solar heat gain during the winter months, the building has been designed to have an aspect ratio of 1.5:1, which makes the north and south sides of the building longer than the east and west side. The south face of the building will be exposed to solar radiation for the longest time during the winter season. Wall, roof and window values are taken from the ASHRAE 90.1 standards, with windows making up $40 \%$ of the wall area. Windows are furnished with blinds to control the allowance of solar radiation during the summer months. Normally there is a dedicated make up air unit to introduce tempered outside air to the space, where ducts will carry the fresh air to the water loop heat pumps that serve individual zones. For the purpose of simplicity of the analysis, the make-up air unit has not been included in the model as it is independent of the building heating loop. Individual zones are heated and cooled by dedicated fan coil units that maintain minimum temperature starting from 1 hour before the building is occupied and ending 1 hour after the building is occupied; during the unoccupied hours the fan coils operate to maintain setback temperature. Heating and cooling of the building is provided by a natural gas boiler and a centrifugal chiller respectively, which uses a cooling tower for heat rejection. Domestic hot water demand and storage capacity is calculated by eQuest using the occupant density and hours of occupancy. Domestic water heating is provided by natural gas boiler, which is set to meet the minimum energy efficiency of ASHRAE 90.1 standard. The base building has been modelled using the Design Development Wizard in eQuest. Modelling parameters for the base building are shown in table 12 to table 28 . 
Table 12: Base building project and site data

\begin{tabular}{|l|l|}
\hline Design Parameter/Requirement & Value \\
\hline Building Type & Office building, mid-rise \\
\hline Location & Canadian location \\
\hline Region & Ontario region A \\
\hline City & Toronto \\
\hline Jurisdiction & ASHRAE 90.1 \\
\hline Electricity rate & Custom \\
\hline Gas rate & Custom \\
\hline
\end{tabular}

Electricity Time of Use Rate (Source: Toronto Hydro):

According to the summer time of use (TOU) rates, effective May, 2016 to October 31, 2016 the time of use rates for weekdays are shown in table 13. Weekends and statutory holidays are at the lowest price (off-peak) all day. In addition, there is a monthly customer charge of $\$ 30.47 /$ month.

Table 13: Summer time-of-use electricity rate for commercial buildings (Toronto Hydro)

\begin{tabular}{|c|c|c|c|c|c|}
\hline Time of the Day & $\begin{array}{c}\text { Unit } \\
\text { Rate } \\
(\$ / \mathrm{kWh})\end{array}$ & $\begin{array}{c}\text { Delivery } \\
(\$ / \mathrm{kWh})\end{array}$ & $\begin{array}{c}\text { Regulatory } \\
\text { Charge } \\
(\$ / \mathrm{kWh})\end{array}$ & $\begin{array}{c}\text { Debt } \\
\text { Retirement } \\
(\$ / \mathrm{kWh})\end{array}$ & $\begin{array}{c}\text { Total cost } \\
\text { per unit } \\
(\$ / \mathrm{kWh})\end{array}$ \\
\hline $\begin{array}{c}\text { On-peak } \\
11 \mathrm{am}-5 \mathrm{pm}\end{array}$ & 0.18 & 0.044 & 0.050 & 0.007 & 0.281 \\
\hline $\begin{array}{c}\text { Mid-peak } \\
7 \mathrm{am}-11 \mathrm{am} \\
5 \mathrm{pm}-7 \mathrm{pm}\end{array}$ & 0.132 & 0.044 & 0.050 & 0.007 & 0.233 \\
\hline $\begin{array}{c}\text { Off-peak } \\
\mathrm{pm}-7 \mathrm{am}\end{array}$ & 0.087 & 0.044 & 0.050 & 0.007 & 0.188 \\
\hline
\end{tabular}


Winter time of use (TOU) electricity rates are shown in table 13A. Weekends and statutory holidays are at the lowest price (off-peak) all day.

Table 13A: Winter time-of-use electricity rate for commercial buildings (Toronto Hydro)

\begin{tabular}{|c|c|c|c|c|c|}
\hline Time of the Day & $\begin{array}{c}\text { Unit } \\
\text { Rate } \\
(\$ / \mathrm{kWh})\end{array}$ & $\begin{array}{c}\text { Delivery } \\
(\$ / \mathrm{kWh})\end{array}$ & $\begin{array}{c}\text { Regulatory } \\
\text { Charge } \\
(\$ / \mathrm{kWh})\end{array}$ & $\begin{array}{c}\text { Debt } \\
\text { Retirement } \\
(\$ / \mathrm{kWh})\end{array}$ & $\begin{array}{c}\text { Total cost } \\
\text { per unit } \\
(\$ / \mathrm{kWh})\end{array}$ \\
\hline $\begin{array}{c}\text { On-peak } \\
7 \mathrm{am}-11 \mathrm{am} \\
5 \mathrm{pm}-7 \mathrm{pm}\end{array}$ & 0.18 & 0.044 & 0.050 & 0.007 & 0.281 \\
\hline $\begin{array}{c}\text { Mid-peak } \\
11 \mathrm{am}-5 \mathrm{pm}\end{array}$ & 0.132 & 0.044 & 0.050 & 0.007 & 0.233 \\
\hline $\begin{array}{c}\text { Off-peak } \\
\mathrm{pm}-7 \mathrm{am}\end{array}$ & 0.087 & $0.044 \mathrm{~b}$ & 0.050 & 0.007 & 0.188 \\
\hline
\end{tabular}

Natural gas rate has been taken from Enbridge commercial rate, and shown in Table 14. In addition, there is a monthly customer charge of $\$ 70 /$ month.

Table 14: Block charges for natural gas supply for commercial buildings (Source: Enbridge)

\begin{tabular}{|c|c|c|c|c|c|c|}
\hline Blocks $\left(\mathrm{m}^{3}\right)$ & $\begin{array}{c}\text { Unit } \\
\text { charge } \\
(\$ / \mathrm{m} 3)\end{array}$ & $\begin{array}{c}\text { Block } \\
(\text { Therm })\end{array}$ & $\begin{array}{c}\text { Basic cost } \\
(\$ / \text { therm })\end{array}$ & $\begin{array}{c}\text { Supply } \\
\text { Charge } \\
(\$ / \text { therm })\end{array}$ & $\begin{array}{c}\text { Transportation } \\
\text { Charge } \\
(\$ / \text { therm })\end{array}$ & $\begin{array}{c}\text { Total unit } \\
\text { cost } \\
(\$ / \text { therm })\end{array}$ \\
\hline 500 & 0.091180 & 180 & 0.2533 & 0.2556 & 0.1482 & 0.6571 \\
\hline Next 1050 & 0.073162 & 378 & 0.2032 & 0.2556 & 0.1482 & 0.6070 \\
\hline Next 4500 & 0.060543 & 1620 & 0.1682 & 0.2556 & 0.1482 & 0.5720 \\
\hline Next 7000 & 0.052434 & 2520 & 0.1457 & 0.2556 & 0.1482 & 0.5495 \\
\hline Next 15250 & 0.048832 & 5490 & 0.1356 & 0.2556 & 0.1482 & 0.5394 \\
\hline Next 28300 & 0.047928 & 10188 & 0.1331 & 0.2556 & 0.1482 & 0.5369 \\
\hline
\end{tabular}


Table 15: Building shell and footprint

\begin{tabular}{|l|l|}
\hline Building shell area & $60,000 \mathrm{ft}^{2}$ \\
\hline Number of floors above grade & 3 \\
\hline Floor area at each floor & $20,000 \mathrm{ft}^{2}$ \\
\hline Building dimension & $173 \mathrm{ft} \times 115 \mathrm{ft}$ \\
\hline Daylight control & Yes \\
\hline Plan north & Same as actual north \\
\hline Building aspect ratio & $1.5: 1$ \\
\hline Building shape & Rectangular \\
\hline Perimeter depth & $15 \mathrm{ft}$. \\
\hline Floor to floor height & $13 \mathrm{ft}$. \\
\hline Percentage of area in the perimeter zones & $38.8 \%$ \\
\hline Floor to ceiling height & $10 \mathrm{ft}$. \\
\hline
\end{tabular}

Table 16: Building envelope construction

\begin{tabular}{|l|l|}
\hline Roof construction & 4 in. concrete \\
\hline Roof exterior finish & Built-up \\
\hline Roof exterior insulation & 5 in. polyurethane; RSI-5.28 (R-30) \\
\hline Above grade exterior wall construction & 4 in. heavy weight concrete \\
\hline Exterior wall finish & Concrete with medium brown paint \\
\hline Exterior wall insulation & 2 in. polyisocyanurate; RSI-2.47 (R-14) \\
\hline Ground floor exposure & Earth contact \\
\hline Ground floor construction & 6 inch concrete \\
\hline Ground floor insulation & Full under slab insulation; RSI-1.76 (R-10) \\
\hline Infiltration through exterior wall & 0.038 cfm/ft ${ }^{2}$ \\
\hline Interior wall type & Drywall (no additional insulation) \\
\hline
\end{tabular}


Table 17: Exterior doors and windows

\begin{tabular}{|l|l|}
\hline Main entrance door & Revolving glass door at the south face \\
\hline Other doors & 1 glass door at each of the east, west and north \\
\hline Revolving door dimension & Height $=7 \mathrm{ft}$; Width $=6 \mathrm{ft}$. \\
\hline All door glass property & U-factor $=0.32 ;$ SHGC $=0.40$ \\
\hline All door framing & 3 inch wide aluminum with thermal break \\
\hline Exterior wall to window ratio & $40 \%$ \\
\hline Typical window dimension & $6 \mathrm{ft} . \times 6 \mathrm{ft}$. \\
\hline Window property & U-factor $=0.32 ;$ SHGC $=0.40 ; \mathrm{VT}=0.44$ \\
\hline Window framing & Insulated fiberglass, non-operable \\
\hline
\end{tabular}

Table 18: Exterior shades and blinds

\begin{tabular}{|l|l|}
\hline Blind type & Vertical blinds \\
\hline Summer Season (June 21 to September 20) \\
\hline Percent of blinds closed when occupied & $90 \%$ at all sides \\
\hline Percent of blinds closed when unoccupied & $90 \%$ at all sides \\
\hline Winter Season (December 21 to March 20) \\
\hline Percent of blinds closed when occupied & $20 \%$ at all sides \\
\hline Percent of blinds closed when unoccupied & $90 \%$ at all sides \\
\hline Fall/spring season (remaining dates) \\
\hline Percent of blinds closed when occupied & $20 \%$ at all sides \\
\hline Percent of blinds closed when unoccupied & $90 \%$ at all sides \\
\hline
\end{tabular}

Table 19: Roof skylight

\begin{tabular}{|l|l|}
\hline Roof area covered by skylight & $3 \%$ \\
\hline Configuration & Domed with vinyl framing \\
\hline Glazing type & Double acrylic white \\
\hline Inside reflectance & $70 \%$ \\
\hline
\end{tabular}


Table 20: Daylight control

\begin{tabular}{|l|l|}
\hline Daylight control method & On/off \\
\hline Percentage of lighting controlled & $\begin{array}{l}\text { Ground and second floor: 100\% in the } \\
\text { perimeter zones } \\
\text { Third floor: } 100 \% \text { in all zones }\end{array}$ \\
\hline Photosensor per zone & 1 \\
\hline Photosensor height & $2.50 \mathrm{ft}$ \\
\hline
\end{tabular}

Table 21: Building operation schedule

\begin{tabular}{|l|l|}
\hline Monday to Friday & $8: 00 \mathrm{am}-5: 00 \mathrm{pm}$ \\
\hline Saturday & Closed \\
\hline Sunday & Closed \\
\hline Holiday & Closed \\
\hline
\end{tabular}

Table 22: Activity area allocation

\begin{tabular}{|l|l|l|}
\hline Activity type & Percent area (\%) & Max occupancy (ft ${ }^{2} /$ person) \\
\hline Office (open) & 60 & 17 \\
\hline Office (executive) & 20 & 100 \\
\hline Lobby & 5 & 100 \\
\hline Restroom & 5 & 100 \\
\hline Boardroom & 4 & 15 \\
\hline Mechanical/electrical & 4 & 333 \\
\hline Photocopy/Printing & 2 & 333 \\
\hline
\end{tabular}


Table 23: Interior lighting loads

\begin{tabular}{|l|l|}
\hline Area type & Lighting density (W/sq.ft.) \\
\hline Office (open) & 1.10 \\
\hline Office (executive) & 1.10 \\
\hline Lobby & 1.30 \\
\hline Restroom & 0.9 \\
\hline Boardroom & 1.30 \\
\hline Mechanical/electrical & 1.50 \\
\hline Photocopy/Printing & 1.50 \\
\hline
\end{tabular}

Table 24: Office equipment loads and profiles

\begin{tabular}{|l|l|l|}
\hline Area type & Load (W/sq.ft.) & Sensible heat fraction \\
\hline Office (open) & 0.75 & 1.00 \\
\hline Office (executive) & 0.75 & 1.00 \\
\hline Lobby & 0.25 & 1.00 \\
\hline Restroom & 0.10 & 1.00 \\
\hline Boardroom & 0.10 & 1.00 \\
\hline Mechanical/electrical & 0.10 & 1.00 \\
\hline Photocopy/Printing & 0.70 & 1.00 \\
\hline
\end{tabular}


Table 25: Zone HVAC system parameters

\begin{tabular}{|l|l|}
\hline System type & 4-pipe fan coil units \\
\hline Location & System per zone \\
\hline Cooling source & Chilled water coils \\
\hline Heating source & Hot water coils \\
\hline Zone thermostat set point for heating & Occupied : $70^{\circ} \mathrm{F}$; Unoccupied: $60^{\circ} \mathrm{F}$ \\
\hline Zone thermostat set point for cooling & Occupied : $75^{\circ} \mathrm{F}$; Unoccupied: $82^{\circ} \mathrm{F}$ \\
\hline Cooling supply temperature & $55^{\circ} \mathrm{F}$ \\
\hline Heating supply temperature & $95^{\circ} \mathrm{F}$ \\
\hline Fan operation hours & 24 hours based on demand \\
\hline Night time cycling & Cycles fan \\
\hline Night cycle fan mode & Intermittent \\
\hline & \\
\hline
\end{tabular}

Table26: Cooling primary equipment design parameters

\begin{tabular}{|l|l|}
\hline Chiller type & Electric centrifugal hermetic \\
\hline Condenser type & Water cooled \\
\hline Chiller sizing & Auto \\
\hline Compressor & Variable speed \\
\hline Chiller COP & 3.8 (ASHRAE 90.1) \\
\hline Pump configuration & Single system pump \\
\hline Chilled water loop flow & Variable \\
\hline Heat rejection equipment & Water cooled cooling tower \\
\hline Condenser configuration & Open tower \\
\hline Temperature control & Temperature reset based on demand \\
\hline Capacity control & Variable speed fan \\
\hline Chilled water temperature set point & $44^{\circ} \mathrm{F}$ \\
\hline Operation control & On demand \\
\hline Operating hours & 24 hours based on demand \\
\hline
\end{tabular}


Table 27: Heating primary equipment

\begin{tabular}{|l|l|}
\hline Heating equipment & Natural gas fired hot water boiler \\
\hline Sizing & Auto \\
\hline Boiler efficiency & $80 \%$ (ASHRAE 90.1) \\
\hline Pump configuration & Single system pump-variable speed \\
\hline Hot water loop temperature & Load reset between $140^{\circ} \mathrm{F}$ and $180^{\circ} \mathrm{F}$ \\
\hline Operation control & On demand \\
\hline Operating hours & 24 hours on demand \\
\hline
\end{tabular}

Table 28: Domestic hot water modeling parameter

\begin{tabular}{|l|l|}
\hline Heat source & Natural gas \\
\hline Heating efficiency & $80 \%$ (ASHRAE 90.1) \\
\hline Input rating & 1,748 kBtu (calculated by eQuest) \\
\hline Tank capacity & 1,235 gallons (calculated by eQuest) \\
\hline Supply water & $140^{\circ} \mathrm{F}\left(60^{\circ} \mathrm{C}\right)$ \\
\hline Cold water temperature (at inlet) & Same as seasonal ground temperature \\
\hline
\end{tabular}

Once the modelling is completed, eQuest produced 3D view of the three storey building (shown in Figure 22), and schematic view of the heating, cooling and domestic hot water (DHW) system (shown in Figure 23). 


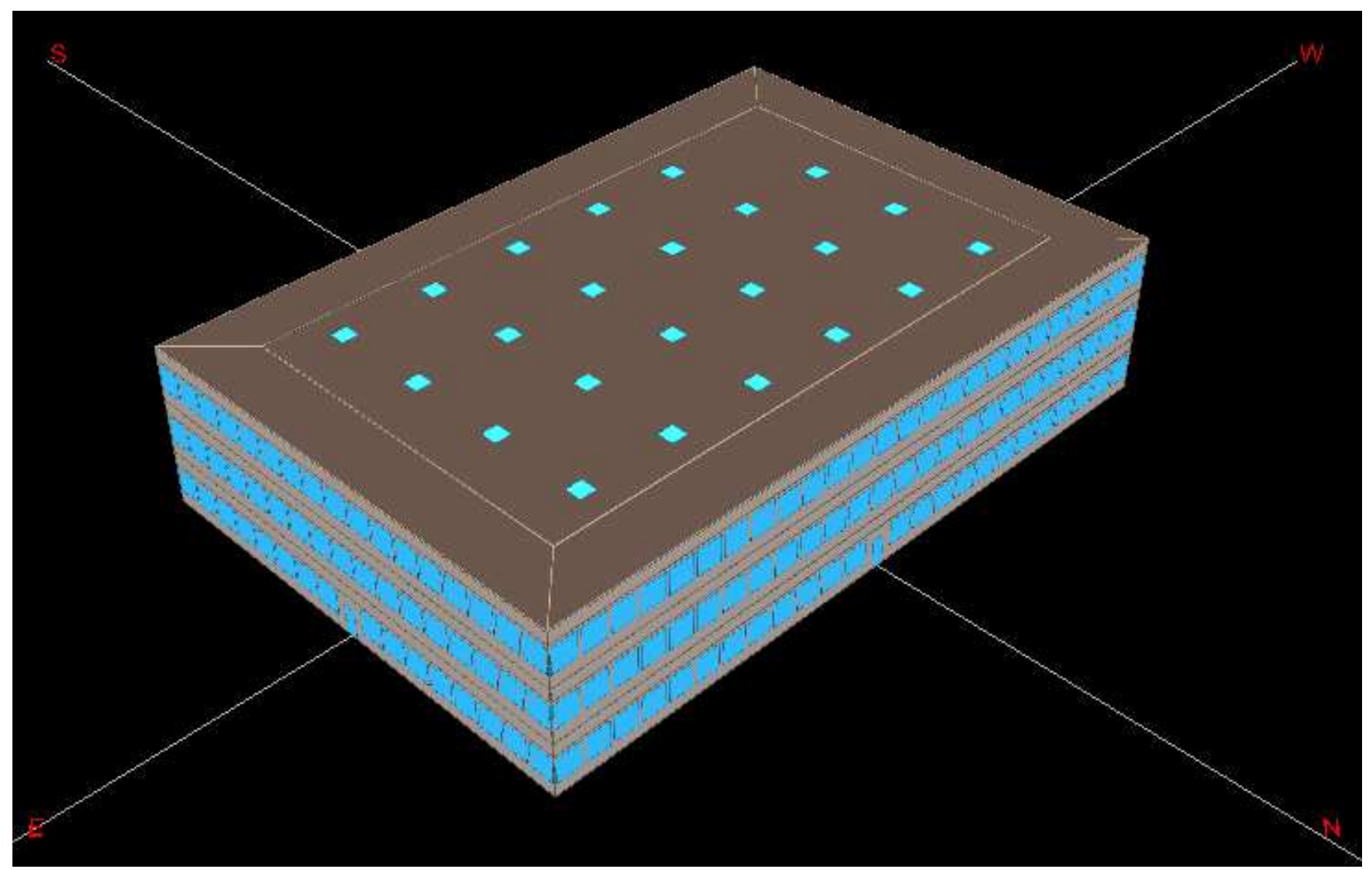

Figure 22: 3D view of the three storey office building 


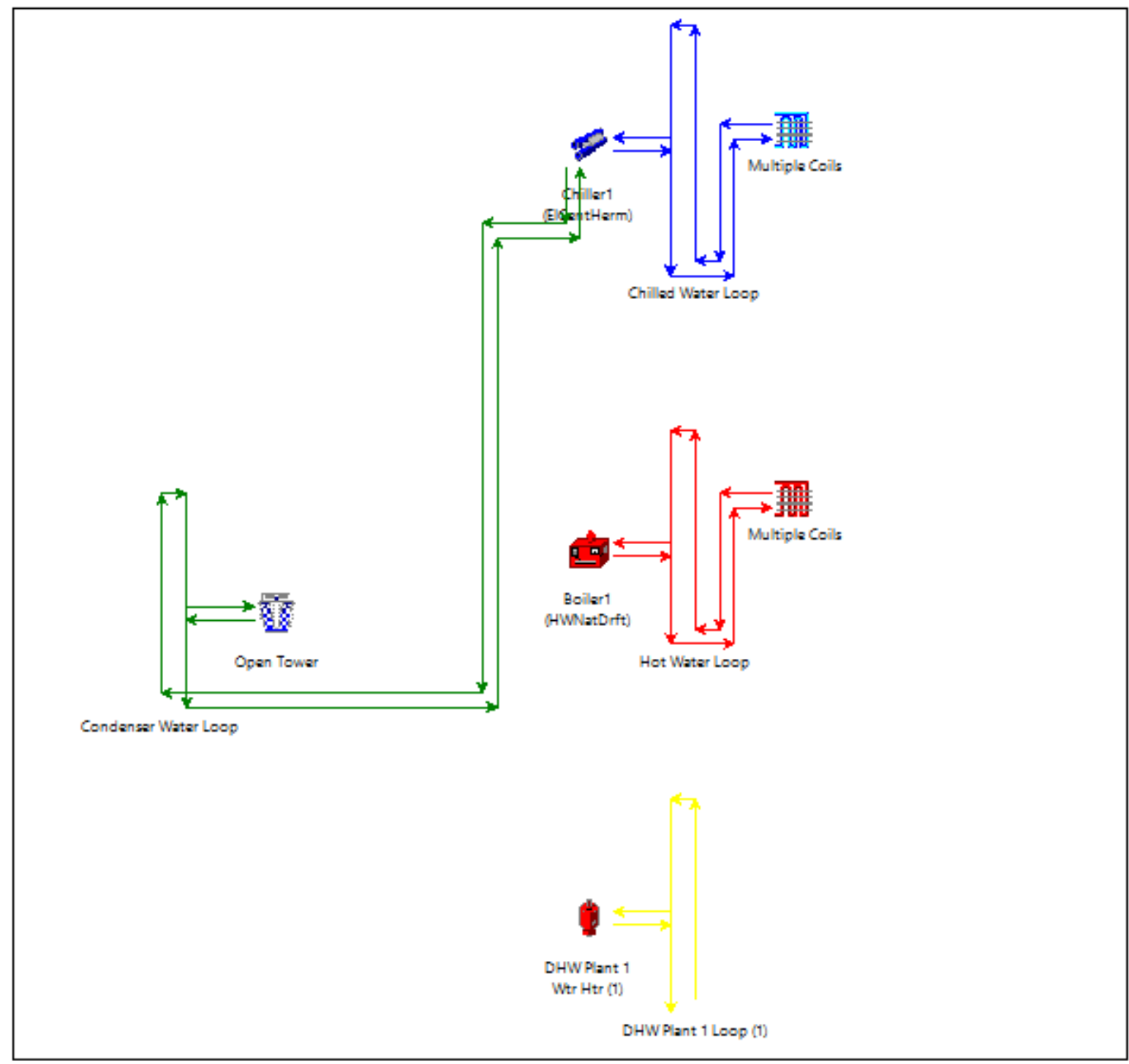

Figure 23: Heating, cooling and domestic hot water heating schematic produced by eQuest

\subsubsection{Base Case Simulation Result}

After simulation of the base building, eQuest has produced detailed load and energy consumption data. Peak heating and cooling loads of the building are $261.9 \mathrm{kBtu} / \mathrm{h}(76.7 \mathrm{~kW})$ and $1458.4 \mathrm{kBtu} / \mathrm{h}(427.3 \mathrm{~kW})$ respectively. The peak load components for the building and their effects on the heating and cooling loads are shown in Table 29. 
Table 29: Building peak load and components (from eQuest simulation result)

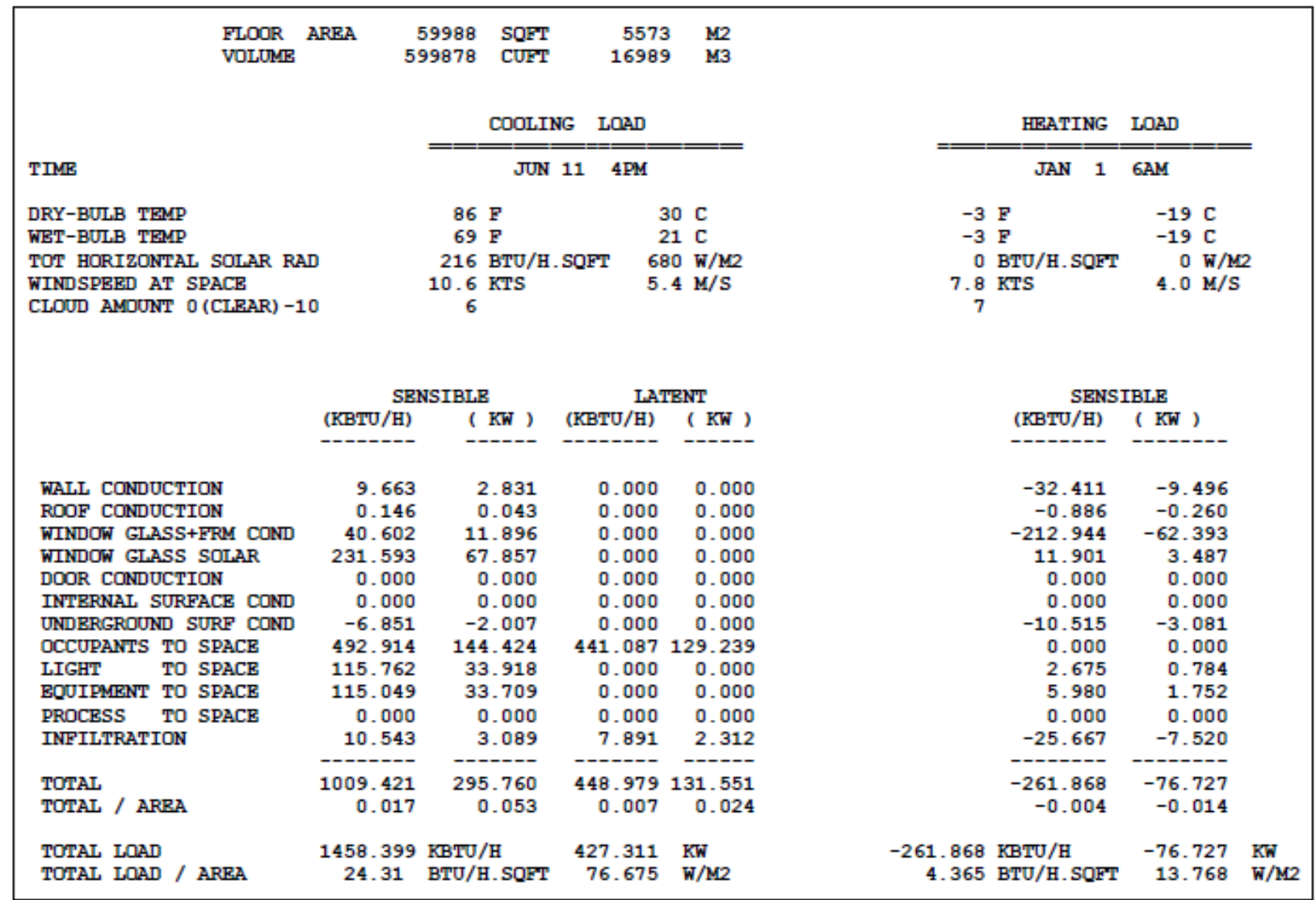

Zone peak heating and cooling loads generated by eQuest are shown in table 30. It is worth noting that at any floor, though the south and the north perimeter zones have same area, the heating load is higher in the north as it gains less solar heat than the south. Similarly, cooling load is lesser in the north perimeter than the south because the north gains less solar radiation than the south. 
Table 30: Zone peak heating and cooling loads (eQuest simulation result)

\begin{tabular}{|l|l|l|l|l|}
\hline Zone & Heating Load & \multicolumn{2}{l|}{ Cooling Load } \\
\hline & $\mathrm{kBtu} / \mathrm{h}$ & $\mathrm{kW}$ & $\mathrm{kBtu} / \mathrm{h}$ & $\mathrm{kW}$ \\
\hline Ground floor south perimeter & 24 & 7.1 & 46 & 13.4 \\
\hline Ground floor east perimeter & 18 & 5.4 & 29 & 8.4 \\
\hline Ground floor north perimeter & 29 & 8.5 & 23 & 6.6 \\
\hline Ground floor west perimeter & 19 & 5.6 & 26 & 7.5 \\
\hline Ground floor core zone & 2 & 0.7 & 186 & 54.5 \\
\hline Second floor south perimeter & 26 & 7.7 & 70 & 20.4 \\
\hline Second floor east perimeter & 18 & 5.4 & 45 & 13.1 \\
\hline Second floor north perimeter & 28 & 8.3 & 33 & 9.8 \\
\hline Second floor west perimeter & 19 & 5.5 & 40 & 11.7 \\
\hline Second floor core zone & 0 & 0.1 & 217 & 63.7 \\
\hline Third floor south perimeter & 31 & 9.0 & 71 & 20.9 \\
\hline Third floor east perimeter & 21 & 6.2 & 46 & 13.4 \\
\hline Third floor north perimeter & 33 & 9.6 & 35 & 10.3 \\
\hline Third floor west perimeter & 22 & 6.4 & 41 & 12.0 \\
\hline Third floor core zone & 51 & 14.8 & 270 & 79.0 \\
\hline
\end{tabular}

Monthly total energy consumption is shown in Table 31 and monthly total gas consumption is shown in table 32. From the monthly electricity consumption, it is evident that space cooling is needed in even in the coldest months (December, January and February). This is due to the cooling requirement in the core zones, which gain internal heat bur looses very little or no heat to the external atmosphere. Cooling load is higher during the summer months because all zones require cooling during then. Space heating energy consumption is the highest during the coldest months and it reduces in the shoulder seasons. During the hottest months (June, July, August and September) there is no space heating related energy consumption. Energy consumption related to domestic water heating does not change drastically from month to month; this is due to the consistency in the demand of domestic hot water. It can be noticed that the energy consumption for domestic water heating is higher during the winter months because the incoming cold water temperature is lower due to the colder earth temperature, thus more energy 
is required to raise the water temperature to $140{ }^{\circ} \mathrm{F}$.

Table 31: Monthly total electricity consumption in $\mathrm{kWh}$ x 1000 (generated by eQuest)

\begin{tabular}{|l|l|l|l|l|l|l|l|l|l|l|l|l|l|}
\hline End Use & Jan & Feb & Mar & Apr & May & Jun & Jul & Aug & Sep & Oct & Nov & Dec & Total \\
\hline Space Cool & 9.8 & 10.0 & 12.4 & 12.7 & 13.6 & 20.9 & 24.4 & 22.7 & 16.9 & 12.2 & 10.8 & 11.1 & 177.5 \\
\hline Heat Reject. & 0.1 & 0.1 & 0.1 & 0.2 & 0.3 & 0.7 & 1.0 & 1.0 & 0.6 & 0.3 & 0.2 & 0.1 & 4.6 \\
\hline Refrigeration & - & - & - & - & - & - & - & - & - & - & - & - & - \\
\hline Space Heat & - & - & - & - & - & - & - & - & - & - & - & - & - \\
\hline HP Supp. & - & - & - & - & - & - & - & - & - & - & - & - & - \\
\hline Hot Water & - & - & - & - & - & - & - & - & - & - & - & - & - \\
\hline Vent. Fans & 1.1 & 1.0 & 1.2 & 1.3 & 1.4 & 1.9 & 1.9 & 1.9 & 1.6 & 1.2 & 1.0 & 1.1 & 16.6 \\
\hline $\begin{array}{l}\text { Pumps \& } \\
\text { Aux }\end{array}$ & 3.4 & 3.4 & 4.1 & 4.2 & 4.7 & 6.8 & 8.6 & 7.7 & 5.9 & 4.1 & 3.5 & 3.8 & 60.0 \\
\hline Ext. Usage & - & - & - & - & - & - & - & - & - & - & - & - & - \\
\hline Misc. Equip. & 9.7 & 9.5 & 11.4 & 10.9 & 10.1 & 10.9 & 10.5 & 11.0 & 10.5 & 10.1 & 10.1 & 10.5 & 125.2 \\
\hline Task Lights & - & - & - & - & - & - & - & - & - & - & - & - & - \\
\hline Area Lights & 11.8 & 11.3 & 13.0 & 12.0 & 10.2 & 11.1 & 11.0 & 11.0 & 11.4 & 11.6 & 13.0 & 13.4 & 140.7 \\
\hline Total & 35.9 & 35.4 & 42.1 & 41.2 & 40.3 & 52.3 & 57.4 & 55.3 & 46.8 & 39.4 & 38.5 & 40.0 & 524.5 \\
\hline
\end{tabular}

Yearly utility bill for the base case is $\$ 132,404$, of which $\$ 125,171$ is for electricity and $\$ 7,233$ is for natural gas.

The greenhouse gas $\left(\mathrm{CO}_{2}\right)$ emission factor in Ontario for natural gas is $1,879 \mathrm{gram} / \mathrm{m}^{3}$ (Government of Canada, 2011). Based on that natural gas consumption of 1056 million Btu, which is equivalent to $29,316 \mathrm{~m}^{3}$, produces . Therefore, 55,084,764 grams (55.1 tonnes) of green house gas will be reduced.

Greenhouse gas $\left(\mathrm{CO}_{2}\right)$ emission factor for electricity is 244 gram/kWh (City of Toronto, 2007). Based on that, greenhouse gas emission for electricity for the base case is 127 tonnes.

The total greenhouse gas released by the base case is 182.1 tonnes. 
Table 32: Monthly total natural gas consumption in million Btu (table generated by eQuest)

\begin{tabular}{|l|l|l|l|l|l|l|l|l|l|l|l|l|l|}
\hline End Use & Jan & Feb & Mar & Apr & May & Jun & Jul & Aug & Sep & Oct & Nov & Dec & Total \\
\hline Space Cool & - & - & - & - & - & - & - & - & - & - & - & - & - \\
\hline Heat Reject. & - & - & - & - & - & - & - & - & - & - & - & - & - \\
\hline Refrigeration & - & - & - & - & - & - & - & - & - & - & - & - & - \\
\hline Space Heat & 106.8 & 77.9 & 49.4 & 16.2 & 0.9 & - & - & - & - & 8.0 & 36.1 & 77.2 & 372.5 \\
\hline HP Supp. & - & - & - & - & - & - & - & - & - & - & - & - & - \\
\hline Hot Water & 57.7 & 58.9 & 70.8 & 66.7 & 57.4 & 57.8 & 52.0 & 51.8 & 49.3 & 49.3 & 52.6 & 59.2 & 683.5 \\
\hline Vent. Fans & - & - & - & - & - & - & - & - & - & - & - & - & - \\
\hline $\begin{array}{l}\text { Pumps \& } \\
\text { Aux }\end{array}$ & - & - & - & - & - & - & - & - & - & - & - & - & - \\
\hline Ext. Usage & - & - & - & - & - & - & - & - & - & - & - & - & - \\
\hline Misc. Equip. & - & - & - & - & - & - & - & - & - & - & - & - & - \\
\hline Task Lights & - & - & - & - & - & - & - & - & - & - & - & - & - \\
\hline Area Lights & - & - & - & - & - & - & - & - & - & - & - & - & - \\
\hline Total & 164.5 & 136.8 & 120.2 & 82.8 & 58.3 & 57.8 & 52.0 & 51.8 & 49.3 & 57.4 & 88.6 & 136.4 & 1056.0 \\
\hline
\end{tabular}

Base building simulation results are shown in Appendix C.

\subsection{Proposed Case 1}

The proposed case is similar to the base case except that it uses distributed water loop heat pump system for space heating and cooling. Building envelope design, occupancy, lighting, office equipment and water heating parameters remain same as the base building. Therefore it is expected that the space heating and cooling loads will not change, but the energy consumption due to heating and cooling operation will change due to change of the HVAC system. Similar to the base case, in the proposed case, make up air has not been included in the model for the purpose of simplicity as it is independent of the space heating and cooling system. The water source heat pump design parameters are shown in Table 33 and Table 34. 
Table 33: Zone HVAC system parameters

\begin{tabular}{|l|l|}
\hline System type & Water source heat pumps \\
\hline Location & System per zone \\
\hline Cooling source & Water loop \\
\hline Heating source & Hot water loop \\
\hline Zone thermostat set point for heating & Occupied : $70^{\circ} \mathrm{F}$; Unoccupied: $60^{\circ} \mathrm{F}$ \\
\hline Zone thermostat set point for Cooling & Occupied : $75^{\circ} \mathrm{F}$; Unoccupied: $82^{\circ} \mathrm{F}$ \\
\hline Cooling supply air temperature & $55^{\circ} \mathrm{F}$ \\
\hline Heating supply air temperature & $95^{\circ} \mathrm{F}$ \\
\hline Cooling Energy Efficiency Ratio (EER) & $13.0($ ASHRAE 90.1$)$ \\
\hline Heating Coefficient of Performance (COP) & $4.3($ ASHRAE 90.1$)$ \\
\hline Fan operation hours & 24 hours based on demand \\
\hline Night time cycling & Cycles fan \\
\hline Night cycle fan on via & Zone controls \\
\hline
\end{tabular}

Table 34: Water source heat pump plant equipment

\begin{tabular}{|l|l|}
\hline Heat generating equipment & Condensing boiler \\
\hline Fuel type & Natural gas \\
\hline Efficiency & $91.5 \%$ (ASHRAE 90.1) \\
\hline Heat rejection equipment & Water cooled cooling tower \\
\hline Condenser configuration & Open tower \\
\hline Capacity control & Variable speed fan \\
\hline Fan type & Centrifugal \\
\hline Fan efficiency & High \\
\hline Pump configuration & Single loop pump \\
\hline Loop flow & Variable \\
\hline Operation of the pump & On demand \\
\hline Loop minimum temperature & $68^{\circ} \mathrm{F}\left(20^{\circ} \mathrm{C}\right)($ ASHRAE 90.1$)$ \\
\hline Loop maximum temperature & $86^{\circ} \mathrm{F}\left(30^{\circ} \mathrm{C}\right)($ ASHRAE 90.1$)$ \\
\hline
\end{tabular}


Once the water source heat pump was modelled, it created a common loop system, where both heat pumps in heating mode and heat pumps in cooling mode operate simultaneously, thus the heat rejected from the cooling zones can be used in the zones in requirement of heating. The cooling tower and the condensing boiler operate on a need basis to maintain the loop supply temperature between $68{ }^{\circ} \mathrm{F}\left(20^{\circ} \mathrm{C}\right)$ and $86^{\circ} \mathrm{F}\left(30^{\circ} \mathrm{C}\right)$, which are the energy efficiency rating conditions used in ASHRAE 90.1. Upon completion of the proposed case the common loop water source heat pump schematic was generated by eQuest, and it has been shown in Figure 24 .

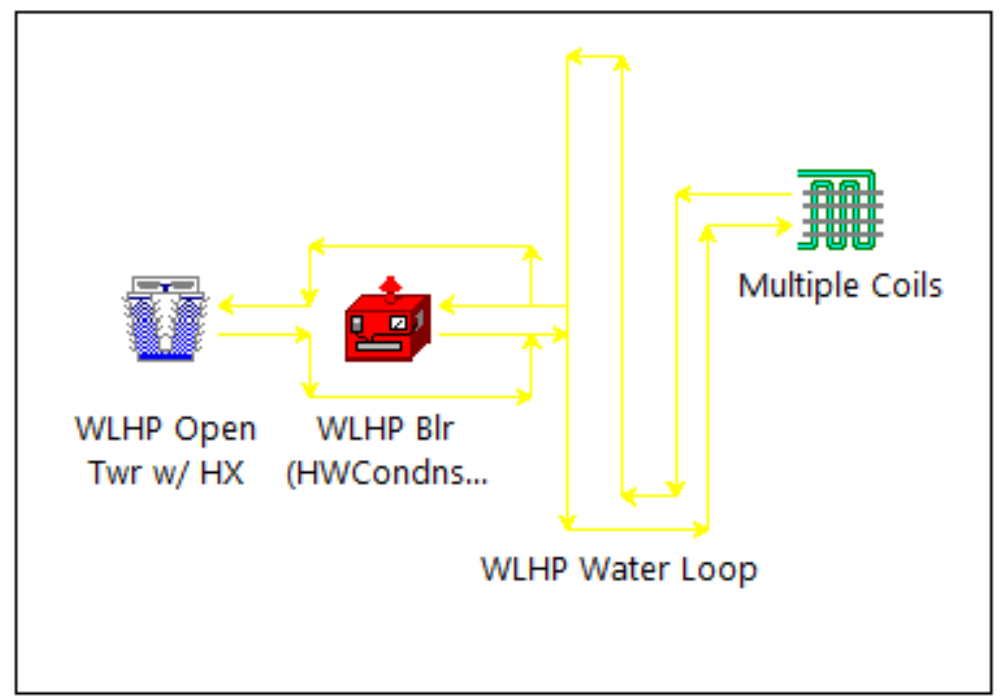

Figure 24: Common loop water source heat pump schematic generated by eQuest

The monthly and annual total electricity and natural gas consumption have been shown in Table 35 and Table 36. It is evident that cooling is required throughout the year though the cooling load doubles between winter and summer. The total annual electricity consumption is 555,370 $\mathrm{kWh}$ and the total natural gas consumption is 711.71 million Btu. 
Table 35: Monthly electricity consumption (kWh x 1000) for proposed Case 1

\begin{tabular}{|l|l|l|l|l|l|l|l|l|l|l|l|l|l|}
\hline End Use & Jan & Feb & Mar & Apr & May & Jun & Jul & Aug & Sep & Oct & Nov & Dec & Total \\
\hline Space Cool & 11.1 & 11.7 & 15.6 & 17.5 & 19.4 & 24.8 & 25.3 & 25.4 & 22.1 & 17.1 & 13.6 & 13.1 & 216.6 \\
\hline Heat Reject. & 0.0 & 0.0 & 0.0 & 0.1 & 0.1 & 0.3 & 0.5 & 0.4 & 0.2 & 0.1 & 0.1 & 0.0 & 1.8 \\
\hline Refrigeration & - & - & - & - & - & - & - & - & - & - & - & - & - \\
\hline Space Heat & 4.2 & 2.5 & 1.2 & 0.2 & 0.0 & - & - & - & - & 0.1 & 0.9 & 2.6 & 11.7 \\
\hline HP Supp. & - & - & - & - & - & - & - & - & - & - & - & - & - \\
\hline Hot Water & - & - & - & - & - & - & - & - & - & - & - & - & - \\
\hline Vent. Fans & 1.5 & 1.4 & 1.7 & 1.7 & 1.8 & 2.4 & 2.5 & 2.5 & 2.1 & 1.6 & 1.4 & 1.6 & 22.2 \\
\hline $\begin{array}{l}\text { Pumps \& } \\
\text { Aux }\end{array}$ & 2.6 & 2.5 & 2.8 & 2.8 & 3.0 & 3.8 & 4.4 & 3.9 & 3.3 & 2.7 & 2.4 & 2.8 & 37.1 \\
\hline Ext. Usage & - & - & - & - & - & - & - & - & - & - & - & - & - \\
\hline Misc. Equip. & 9.7 & 9.5 & 11.4 & 10.9 & 10.1 & 10.9 & 10.5 & 11.0 & 10.5 & 10.1 & 10.1 & 10.5 & 125.2 \\
\hline Task Lights & - & - & - & - & - & - & - & - & - & - & - & - & - \\
\hline Area Lights & 11.8 & 11.3 & 13.0 & 12.0 & 10.2 & 11.1 & 11.0 & 11.0 & 11.4 & 11.6 & 13.0 & 13.4 & 140.7 \\
\hline Total & 41.0 & 39.0 & 45.6 & 45.2 & 44.7 & 53.3 & 54.1 & 54.2 & 49.6 & 43.2 & 41.4 & 44.0 & 555.37 \\
\hline
\end{tabular}


Table 36: Month natural gas consumption (million Btu) for proposed Case 1

\begin{tabular}{|l|l|l|l|l|l|l|l|l|l|l|l|l|l|}
\hline End Use & Jan & Feb & Mar & Apr & May & Jun & Jul & Aug & Sep & Oct & Nov & Dec & Total \\
\hline Space Cool & - & - & - & - & - & - & - & - & - & - & - & - & - \\
\hline Heat Reject. & - & - & - & - & - & - & - & - & - & - & - & - & - \\
\hline Refrigeration & - & - & - & - & - & - & - & - & - & - & - & - & - \\
\hline Space Heat & 18.4 & 5.0 & 0.4 & - & - & - & - & - & - & - & - & 4.4 & 28.1 \\
\hline HP Supp. & - & - & - & - & - & - & - & - & - & - & - & - & - \\
\hline Hot Water & 57.7 & 58.9 & 70.8 & 66.7 & 57.4 & 57.8 & 52.0 & 51.8 & 49.4 & 49.3 & 52.6 & 59.2 & 683.6 \\
\hline Vent. Fans & - & - & - & - & - & - & - & - & - & - & - & - & - \\
\hline $\begin{array}{l}\text { Pumps \& } \\
\text { Aux }\end{array}$ & - & - & - & - & - & - & - & - & - & - & - & - & - \\
\hline Ext. Usage & - & - & - & - & - & - & - & - & - & - & - & - & - \\
\hline Misc. Equip. & - & - & - & - & - & - & - & - & - & - & - & - & - \\
\hline Task Lights & - & - & - & - & - & - & - & - & - & - & - & - & - \\
\hline Area Lights & - & - & - & - & - & - & - & - & - & - & - & - & - \\
\hline Total & 76.1 & 63.9 & 71.2 & 66.7 & 57.4 & 57.8 & 52.0 & 51.8 & 49.4 & 49.3 & 52.6 & 63.6 & 711.71 \\
\hline
\end{tabular}

In order to verify that the heat rejected from the heat pumps in cooling mode is used for heating in zones requiring heat, hourly energy consumption data has been checked. On January $4^{\text {th }}$, which is one of the coldest days of the year, there are both heating and cooling loads during the occupied hours, shown in Table 37 (generated from eQuest hourly data). It can be noticed that there is natural gas consumption by the heating boiler from the $1^{\text {st }}$ hour to the $10^{\text {th }}$ hour, when there is no cooling operation. Once the cooling operation beings at the $10^{\text {th }}$ hour, the heating natural gas consumption become zero due to simultaneous heating and cooling operation. 
Table 37: Hourly energy consumption data on January $4^{\text {th }}, 2016$

\begin{tabular}{|c|c|c|c|c|c|c|c|c|}
\hline Month & Day & Hour & $\begin{array}{l}\text { Heating end- } \\
\text { use energy } \\
\text { (kWh) }\end{array}$ & $\begin{array}{c}\text { Cooling end- } \\
\text { use energy } \\
(\mathrm{kWh})\end{array}$ & $\begin{array}{c}\text { Heat rejection } \\
\text { end-use } \\
\text { energy }(\mathrm{kWh})\end{array}$ & $\begin{array}{l}\text { Heating end- } \\
\text { use energy } \\
\text { (Btu) }\end{array}$ & $\begin{array}{c}\text { Domestic } \\
\text { hot water } \\
\text { end-use }\end{array}$ & $\begin{array}{l}\text { Total end-use } \\
\text { energy (Btu) }\end{array}$ \\
\hline 1 & 4 & 1 & 18.470 & 0.000 & 0.000 & 147228 & 20908 & 168136 \\
\hline 1 & 4 & 2 & 18.175 & 0.000 & 0.000 & 143293 & 20909 & 164202 \\
\hline 1 & 4 & 3 & 18.337 & 0.000 & 0.000 & 145238 & 20901 & 166140 \\
\hline 1 & 4 & 4 & 18.267 & 0.000 & 0.000 & 144376 & 20900 & 165275 \\
\hline 1 & 4 & 5 & 18.150 & 0.000 & 0.000 & 142862 & 20898 & 163759 \\
\hline 1 & 4 & 6 & 18.328 & 0.000 & 0.000 & 145107 & 20896 & 166004 \\
\hline 1 & 4 & 7 & 17.424 & 0.000 & 0.000 & 139135 & 36557 & 175692 \\
\hline 1 & 4 & 8 & 55.269 & 0.000 & 0.000 & 615185 & 159247 & 774432 \\
\hline 1 & 4 & 9 & 31.133 & 0.000 & 0.000 & 320112 & 159212 & 479324 \\
\hline 1 & 4 & 10 & 17.157 & 5.806 & 0.000 & 134423 & 281636 & 416059 \\
\hline 1 & 4 & 11 & 12.472 & 17.146 & 0.000 & 0 & 281574 & 281574 \\
\hline 1 & 4 & 12 & 11.861 & 10.349 & 0.000 & 0 & 281461 & 281461 \\
\hline 1 & 4 & 13 & 11.267 & 21.297 & 0.000 & 0 & 281416 & 281416 \\
\hline 1 & 4 & 14 & 9.533 & 44.941 & 0.000 & 0 & 281414 & 281414 \\
\hline 1 & 4 & 15 & 7.345 & 51.478 & 0.000 & 0 & 281391 & 281391 \\
\hline 1 & 4 & 16 & 6.063 & 54.262 & 0.006 & 0 & 218691 & 218691 \\
\hline 1 & 4 & 17 & 7.906 & 42.737 & 0.000 & 0 & 158628 & 158628 \\
\hline 1 & 4 & 18 & 10.626 & 15.664 & 0.000 & 0 & 95959 & 95959 \\
\hline 1 & 4 & 19 & 0.000 & 0.000 & 0.000 & 0 & 67231 & 67231 \\
\hline 1 & 4 & 20 & 0.000 & 0.000 & 0.000 & 0 & 67242 & 67242 \\
\hline 1 & 4 & 21 & 0.000 & 0.000 & 0.000 & 0 & 67250 & 67250 \\
\hline 1 & 4 & 22 & 0.000 & 0.000 & 0.000 & 0 & 20282 & 20282 \\
\hline 1 & 4 & 23 & 0.266 & 0.000 & 0.000 & 0 & 20300 & 20300 \\
\hline 1 & 4 & 24 & 2136 & $n \cap \cap \cap$ & $\cap \cap \cap \cap$ & $n$ & $2 n 310$ & 20310 \\
\hline
\end{tabular}

\subsection{Result Comparison:}

Based on the energy consumption data, Table 38 and Table 39 have been created to compare annual energy consumption between the base case and the proposed Case 1 . 
Table 38: Electricity consumption comparison between base case and proposed case 1

\begin{tabular}{|l|l|l|l|l|}
\hline End Use & Base Case & Proposed Case & Increase/decrease & $\%$ increase/decrease \\
\hline Space Cool & 177.47 & 216.6 & 39.1 & $22.04 \%$ \\
\hline Heat Reject. & 4.59 & 1.8 & -2.8 & $-60.78 \%$ \\
\hline Refrigeration & - & - & & \\
\hline Space Heat & - & 11.7 & & \\
\hline HP Supp. & - & - & & \\
\hline Hot Water & - & - & & \\
\hline Vent. Fans & 16.56 & 22.2 & 5.7 & $34.24 \%$ \\
\hline $\begin{array}{l}\text { Pumps \& } \\
\text { Aux }\end{array}$ & 60.02 & 37.1 & -22.9 & $-38.14 \%$ \\
\hline Ext. Usage & - & - & & \\
\hline Misc. Equip. & 125.23 & 125.2 & 0.0 & $0.00 \%$ \\
\hline Task Lights & - & - & & \\
\hline Area Lights & 140.68 & 140.7 & 0.0 & $5.88 \%$ \\
\hline Total & 524.54 & 555.4 & 30.8 & \\
\hline
\end{tabular}


Table 39: Annual natural gas consumption comparison in million Btu (negative denotes decrease by the proposed case1)

\begin{tabular}{|c|c|c|c|c|}
\hline End Use & Base Case & Proposed Case & Increase/decrease & $\%$ increase/decrease \\
\hline Space Cool & - & - & & \\
\hline Heat Reject. & - & - & & \\
\hline Refrigeration & - & - & & \\
\hline Space Heat & 372.5 & 28.1 & -344.4 & $-92.45 \%$ \\
\hline HP Supp. & - & - & & \\
\hline Hot Water & 683.5 & 683.6 & 0.1 & $0.01 \%$ \\
\hline Vent. Fans & - & - & & \\
\hline $\begin{array}{l}\text { Pumps \& } \\
\text { Aux }\end{array}$ & - & - & & \\
\hline Ext. Usage & - & - & & \\
\hline Misc. Equip. & - & - & & \\
\hline Task Lights & - & - & & \\
\hline Area Lights & - & - & & \\
\hline Total & $1,056.00$ & 711.7 & -344.3 & $-32.60 \%$ \\
\hline
\end{tabular}

There is $30,800 \mathrm{kWh}(5.88 \%)$ increase in electricity consumption by proposed Case 1 ; this is due to the work input to the compressors in the heat pumps for both heating and cooling operations. Electricity consumption by the cooling tower has decreased $60.78 \%$ comparing to the base case due to the exhaust heat from the cooling operation being used for space heating. Natural gas consumption for heating has drastically reduced by 344.4 million Btu $(92.45 \%)$ due to the use of distributed common loop heat pump system, and the overall natural gas consumption has reduced by $32.60 \%$. By converting the reduction of natural gas to equivalent $\mathrm{kWh}$, it can be seen that 100,904.37 equivalent $\mathrm{kWh}$ hour has by saved. Thus, measuring the total equivalent $\mathrm{kWh}$ saving gives $(-100,904.37+30,800)=-70,104.37 \mathrm{kWh}$ of annual energy saving.

\subsection{Greenhouse Gas Emission}

The greenhouse gas (CO2) emission factor in Ontario for natural gas is $1,879 \mathrm{gram} / \mathrm{m}^{3}$ (Government of Canada, 2011). Using the common loop water source heat pump system of 
proposed case 1, the natural gas consumption has been reduced by 344.4 million Btu, which is equivalent to $9,317 \mathrm{~m}^{3}$ of natural gas. Therefore, 17,506,643 grams (17.5 ton) of greenhouse gas will be reduced.

Electricity consumption has increased by $30,800 \mathrm{kWh}$, thus green house gas emission increased by 7.52 tonnes.

Therefore, overall greenhouse gas reduction by Proposed Case 1 is 10 tonnes. 


\section{Modelling for Sensitivity Analysis}

The purpose of the sensitivity analysis is to determine the influence of the change of design parameters of the building as well as the heat pump system. The sensitivity analysis of the proposed common loop water based heat pump system will be re-modelled three times by changing design temperature of the common water loop. The result of the three models will be then compared against the proposed Case 1 to find optimum operating range of the common loop based on energy consumption.

5.1 Sensitivity analysis for finding optimum heat pump system design parameters 5.1.1 Proposed Case 2: Water loop temperature at lowest $50^{\circ} \mathrm{F}$ and highest $86^{\circ} \mathrm{F}$

From the base building simulation result, it is evident that the building is cooling dominated in the winter months. Thus in order to observe the change of energy performance of the common loop heat pump system, the loop temperature of the proposed case has been lowered, which is expected to increase the cooling COP and decrease the heating COP; however, the magnitude of the cooling COP increase is higher than the that of the heating COP (Lian, 2011). For the proposed Case 2, the lowest design temperature of the loop is set at $50^{\circ} \mathrm{F}$ (Lian, 2011). The highest design temperature of the water loop remains $86^{\circ} \mathrm{F}$ (ASHRAE 90.1). Simulation produces annual electricity and natural gas consumption of $\mathbf{5 4 3 , 7 0 0 ~} \mathbf{k W h}$ and 700.5 million Btu respectively.

\subsubsection{Proposed Case 3: Water loop temperature at lowest $50{ }^{\circ} \mathrm{F}$ and highest $72.14{ }^{\circ} \mathrm{F}$}

For the proposed Case 3, the lowest design temperature of the loop is set at $50{ }^{\circ} \mathrm{F}$. The highest design temperature of the water loop is lowered to $78.12^{\circ} \mathrm{F}$, which is the design outdoor wet bulb temperature in Toronto (ASHRAE Fundamental, 2005); this temperature can be achieved by the operation of a cooling tower in summer. Upon simulation, the annual electricity consumption is $\mathbf{5 3 4 , 0 5 0} \mathbf{~} \mathbf{W h}$, and natural gas consumption is $\mathbf{7 0 2 . 3 5}$ million Btu.

\subsubsection{Proposed Case 4: Water loop temperature lowest $68^{\circ} \mathrm{F}$ and highest $72.14^{\circ} \mathrm{F}$}

The water loop minimum is set at $68^{\circ} \mathrm{F}$, which is the design temperature used for minimum energy efficiency requirement in ASHRAE 90.1. The highest temperature of the loop is set at $72.14^{\circ} \mathrm{F}$, which is the design outdoor wet bulb temperature in Toronto (ASHRAE, 
2005). Annual electricity consumption for proposed case 4 is $\mathbf{5 3 3 , 3 4 0 ~} \mathbf{k W h}$, and the natural gas consumption is $\mathbf{7 1 4 . 5 3}$ million Btu.

5.1.4 Annual electricity and natural gas consumption of proposed case 1, 2, 3 and 4 have been compared in table 40, which helps to determine the optimum temperature setting for the common water loop.

Table 40: Sensitivity test to determine optimum temperature of the common loop

\begin{tabular}{|c|c|c|c|c|c|}
\hline & $\begin{array}{c}\text { Base } \\
\text { Case }\end{array}$ & $\begin{array}{c}\text { Proposed } \\
\text { Case 1 }\end{array}$ & $\begin{array}{c}\text { Proposed Case } \\
2\end{array}$ & $\begin{array}{c}\text { Proposed } \\
\text { Case 3 }\end{array}$ & $\begin{array}{c}\text { Proposed } \\
\text { Case 4 }\end{array}$ \\
\hline $\begin{array}{c}\text { Electricity } \\
(\mathrm{kWh})\end{array}$ & 524,500 & 555,370 & 543,700 & 534,050 & 533,340 \\
\hline $\begin{array}{c}\text { Natural Gas } \\
(\text { MMBtu) }\end{array}$ & 1056.0 & 711.71 & 700.5 & 702.35 & 714.53 \\
\hline $\begin{array}{c}\text { Yearly electricity } \\
\text { bill (\$) }\end{array}$ & 125,171 & 137,979 & 135,173 & 132,794 & 132,609 \\
\hline $\begin{array}{c}\text { Yearly natural } \\
\text { gas bill (\$) }\end{array}$ & 7,233 & 5,245 & 5,181 & 5,192 & 5,262 \\
\hline $\begin{array}{c}\text { Total annual } \\
\text { utility bill (\$) }\end{array}$ & 132,404 & 143,224 & 140,354 & 137,986 & 137,871 \\
\hline
\end{tabular}

Though, the electricity consumption of proposed Case 3 is slightly higher than that of proposed case 4 , the natural gas consumption of Case 3 is significantly less than case 4 . Therefore, proposed case 3 is the optimum solution, which suggests the common loop temperature should operate between $50^{\circ} \mathrm{F}$ and highest $72.14^{\circ} \mathrm{F}$.

5.2 Comparison between the base case and proposed case 3

Table 41 compares between the base case and the optimum proposed case in terms of annual electricity consumption, annual natural gas consumption and annual utility bill. 
Table 41: Energy and economic comparison between the base case and proposed case 3

\begin{tabular}{|c|c|c|}
\hline & Base Case & Proposed Case 3 \\
\hline Electricity (kWh) & 524,540 & 534,050 \\
\hline $\begin{array}{c}\text { Natural gas } \\
\text { (MMBtu) }\end{array}$ & $1,056.00$ & 702.35 \\
\hline $\begin{array}{c}\text { Annual utility } \\
\text { bill (\$) }\end{array}$ & 132,404 & 137,986 \\
\hline
\end{tabular}

There is $9,510 \mathrm{kWh}(1.81 \%)$ increase in electricity consumption by proposed case 3 ; this is due to the work input to the compressors in the heat pumps for both heating and cooling operations. Natural gas consumption has been reduced by 353.65 million Btu (33.48\%). Annual utility bill has increased by $\$ 5,582.00$ which is $4.22 \%$ higher than the base case.

The greenhouse gas (CO2) emission factor in Ontario for natural gas is $1,879 \mathrm{gram} / \mathrm{m}^{3}$ (Government of Canada, 2011). Using the common loop water source heat pump system of proposed Case 3, the natural gas consumption has been reduced by 353.65 million Btu, which is equivalent to $9,567.239 \mathrm{~m}^{3}$ of natural gas. Therefore, 17,976,842 grams (17.98 ton) of green house gas will be reduced.

Electricity consumption has increased by $9,510 \mathrm{kWh}$, thus green house gas emission increased by 2.3 tonnes.

Therefore, overall greenhouse gas reduction by Proposed Case 3 is 15.7 tonnes. 


\section{Conclusion}

From the energy and environmental consideration, the common loop water source heat pump system is a significantly better option than the base case; however, from the economic point of view, the base case is better than the proposed case. It should be noted that further natural gas saving can be achieved if the remaining exhaust heat in the common water loop can be stored in a heat storage system, and subsequently used for space heating during the hours when there is no cooling load in the building. During the shoulder season and the summer months, the stored heat can be used for domestic water preheating using a water-to-water heat pump, which provides and excelled opportunity to reduce consumption of natural gas. This will also reduce the electricity consumption of the cooling tower, as the tower will then need to reject less heat to the atmosphere. However, some increase in the electricity consumption is expected due to the work input to the water-to-water heat pump. 
Appendix 1: Conceptual design of common loop water source heat pump with heat storage 


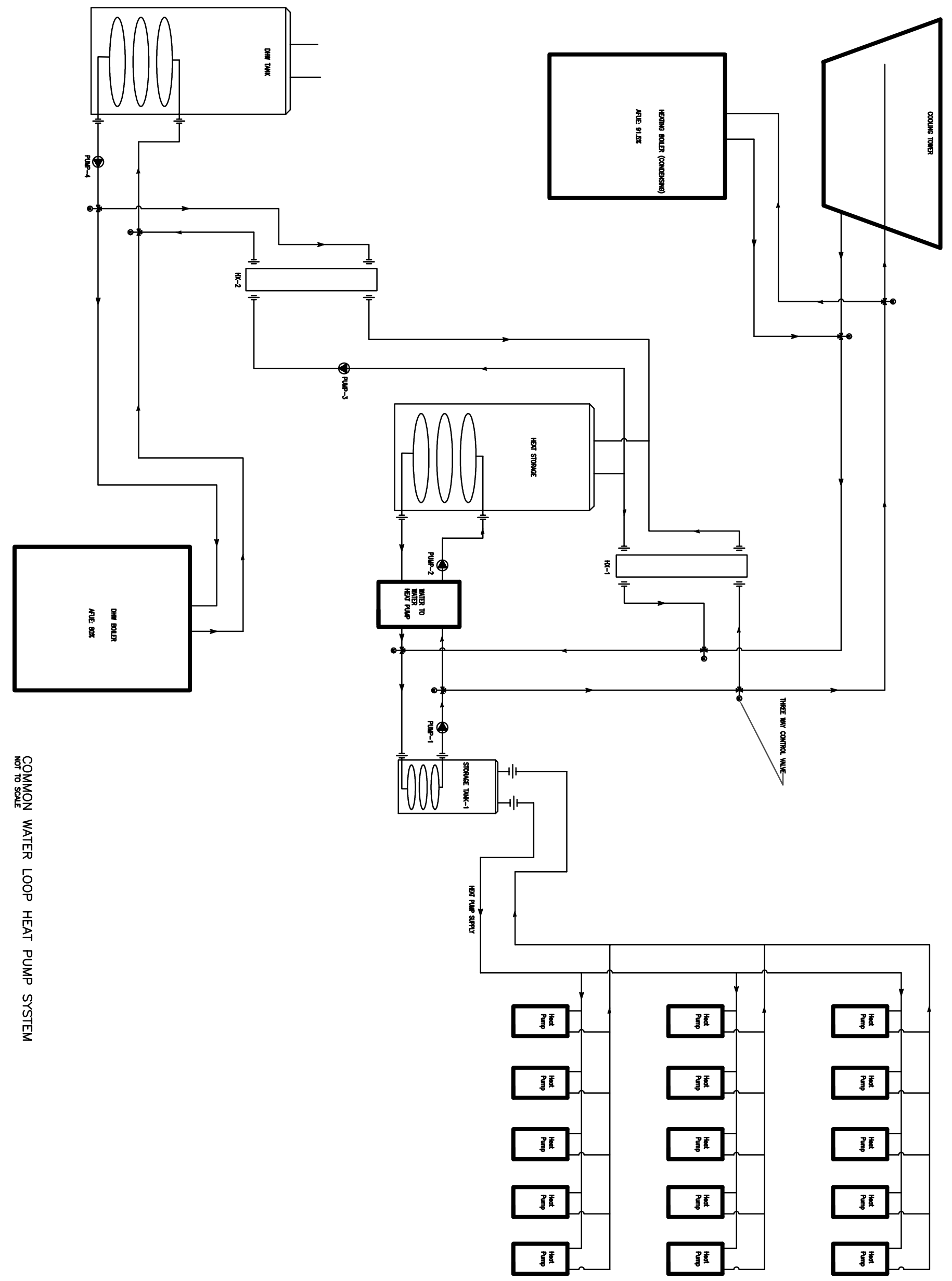


Appendix 2: Typical office floor layout with water source heat pumps 


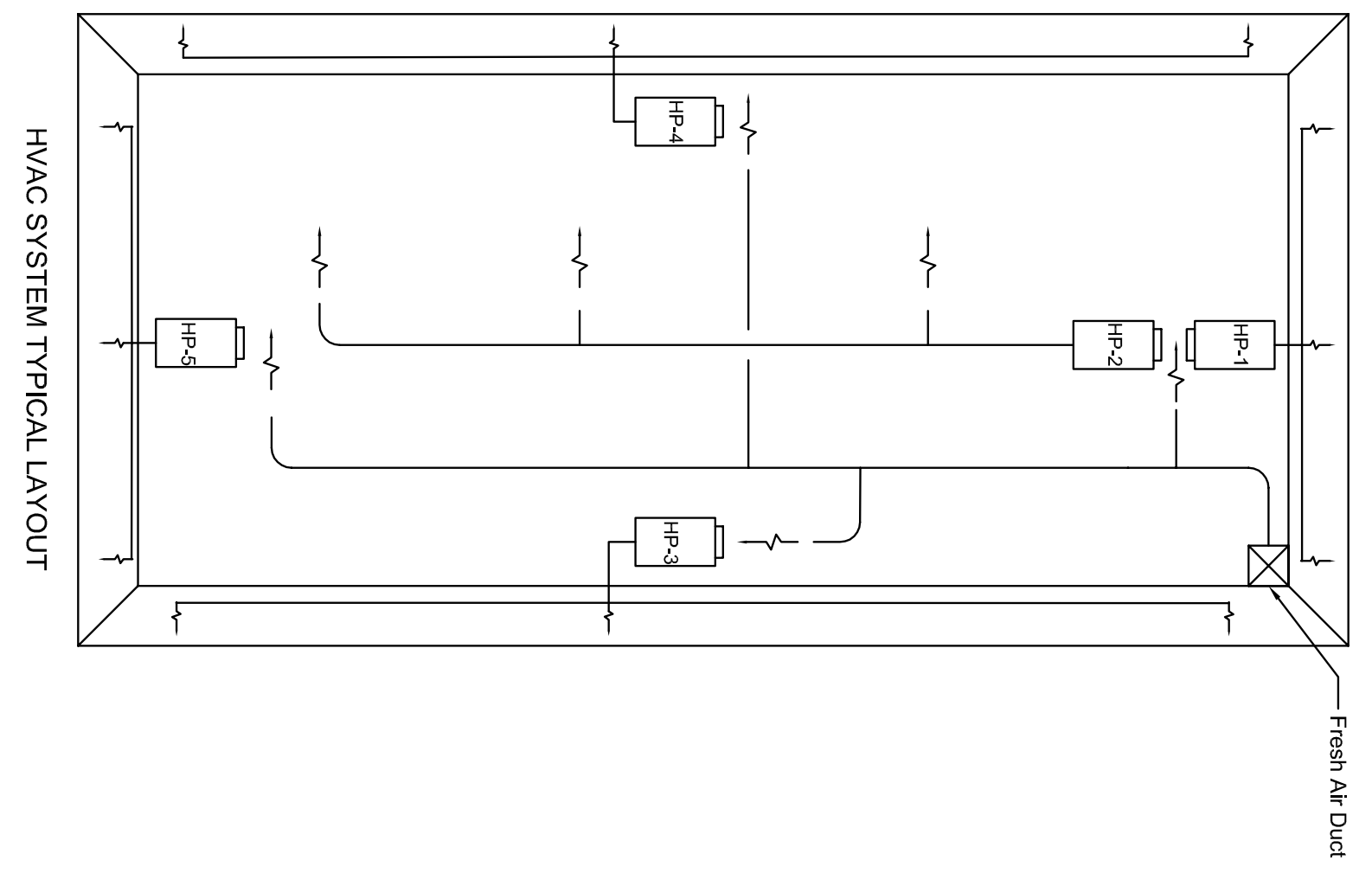


Appendix 3: Building load from eQuest simulation 


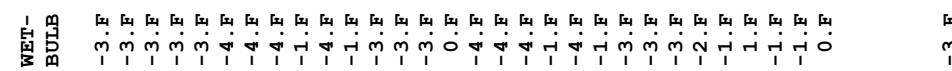

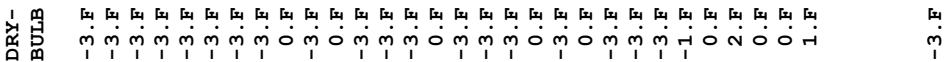

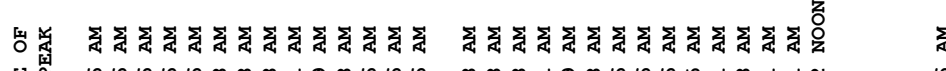

鼠

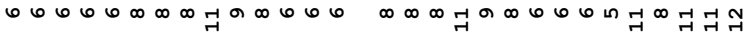

ลิกล กิ

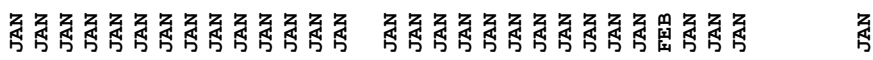

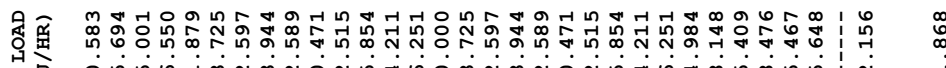

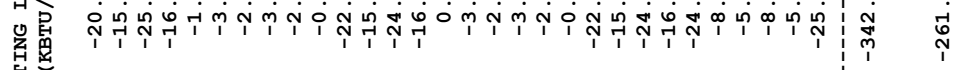

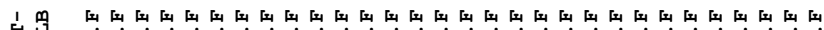

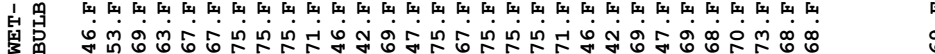

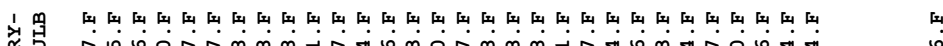

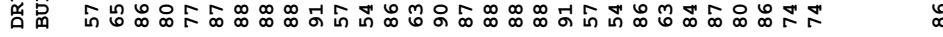

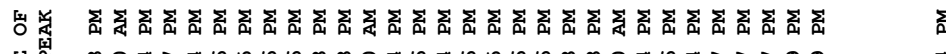

国 morrron

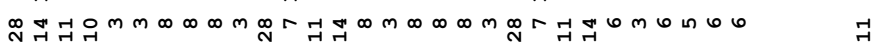

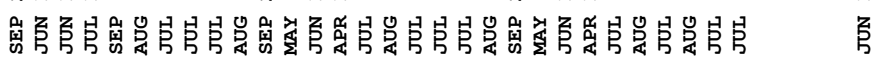

重

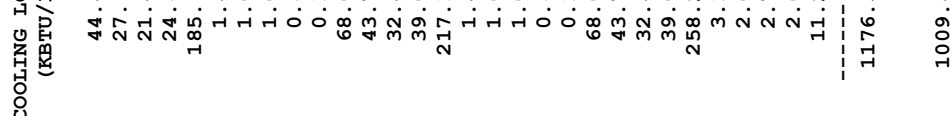

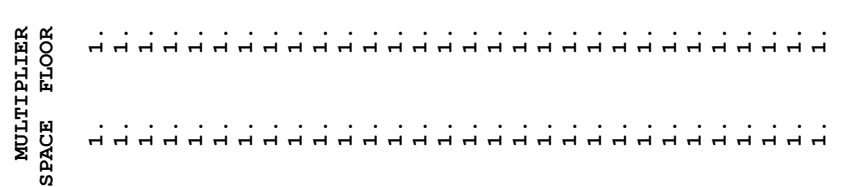

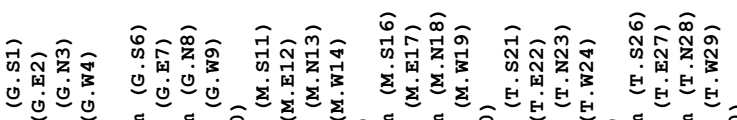

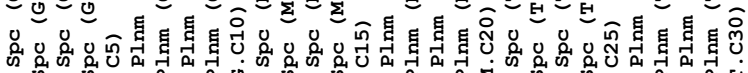

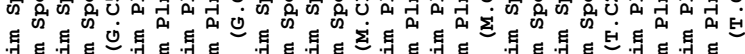

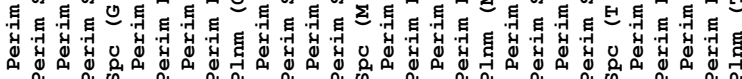

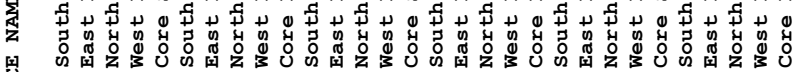

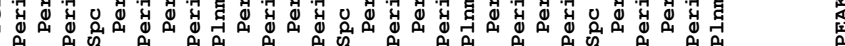

总 

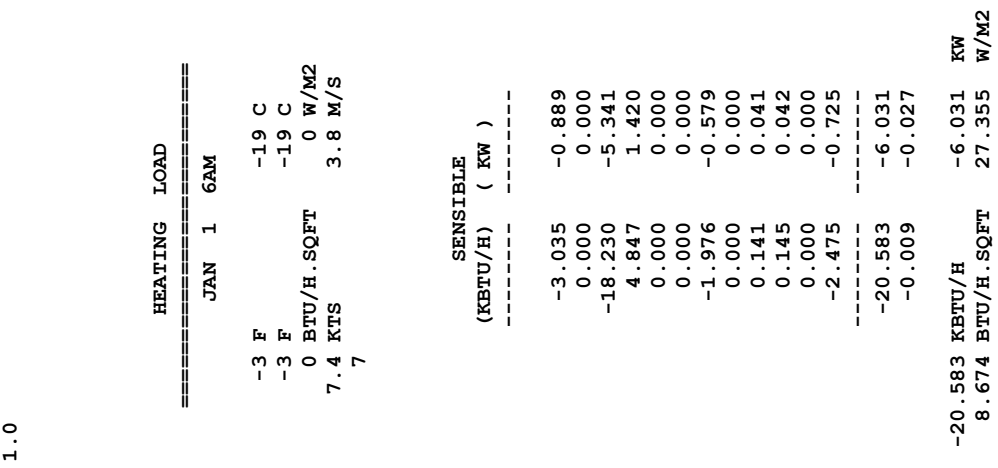

$\stackrel{\circ}{-}$
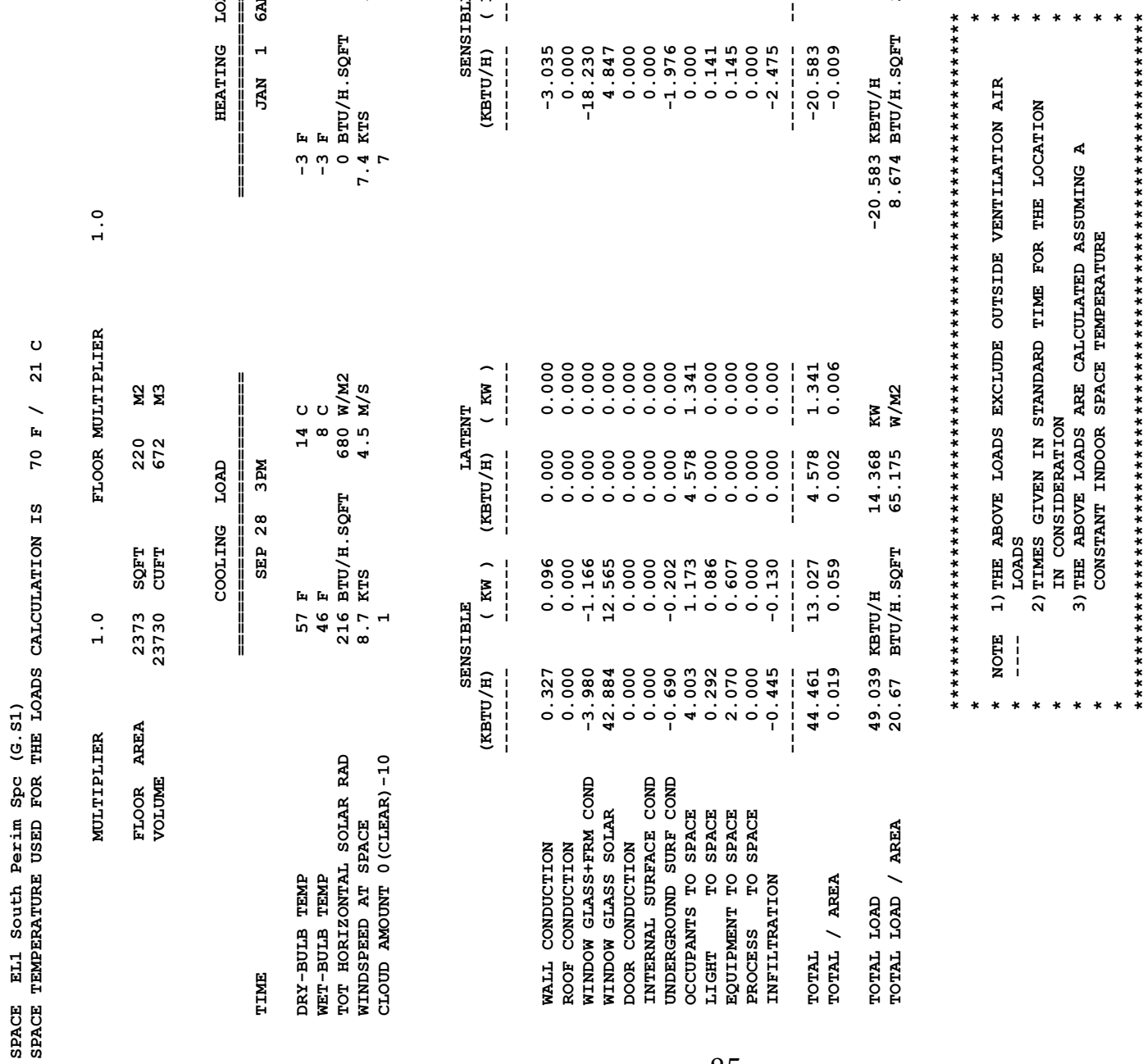


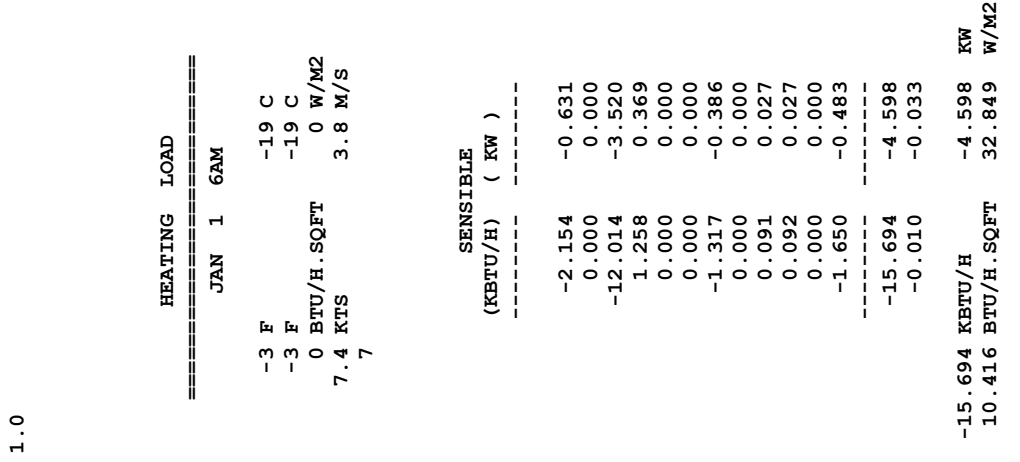

ํ.

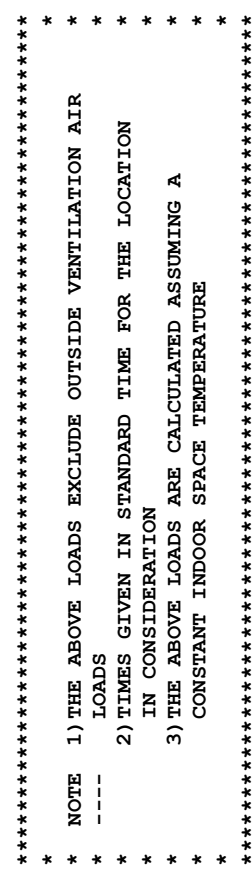

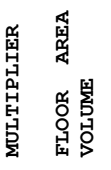
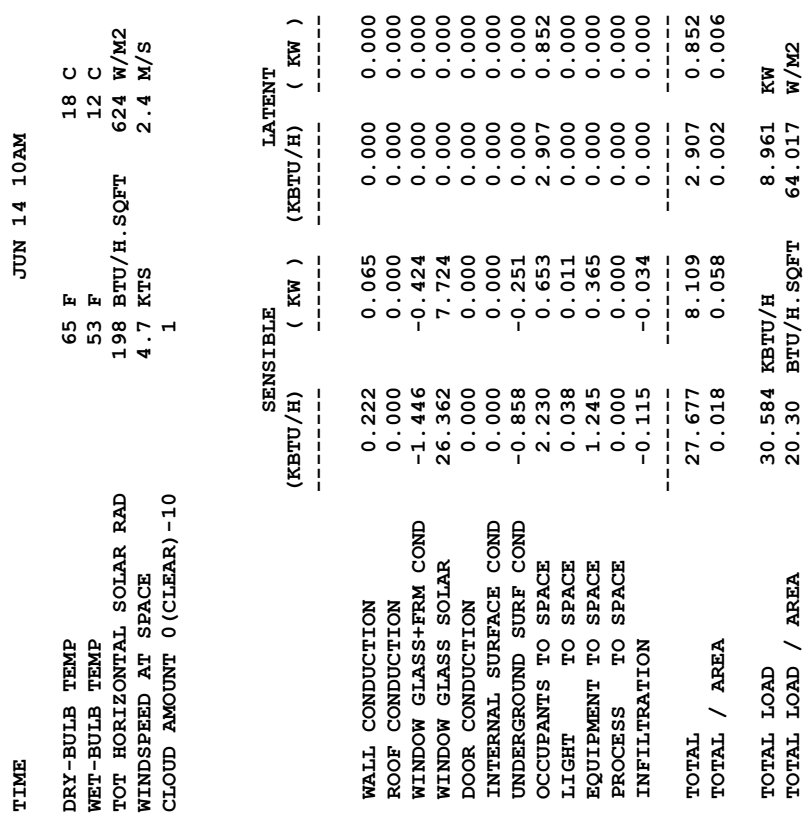


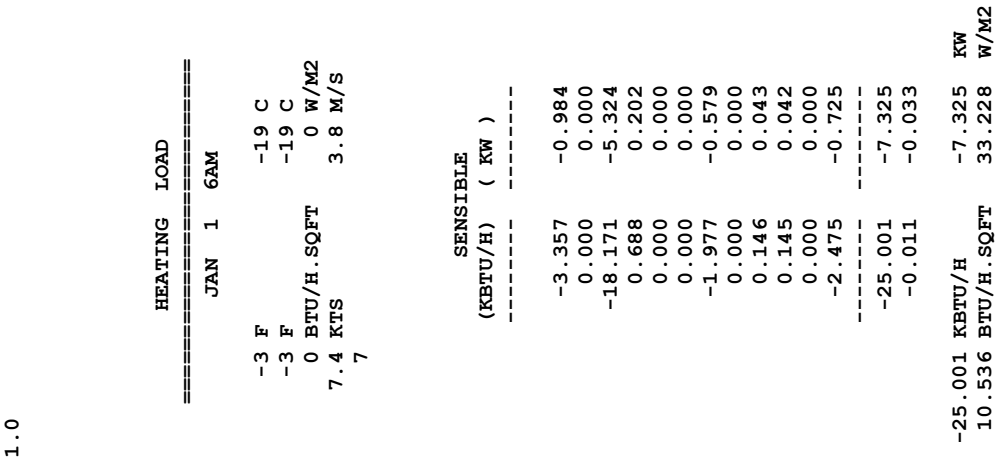

$\stackrel{\circ}{\circ}$

$\sum_{2}$

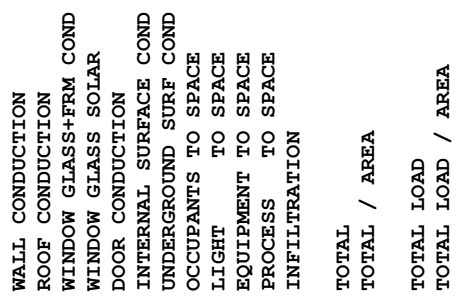




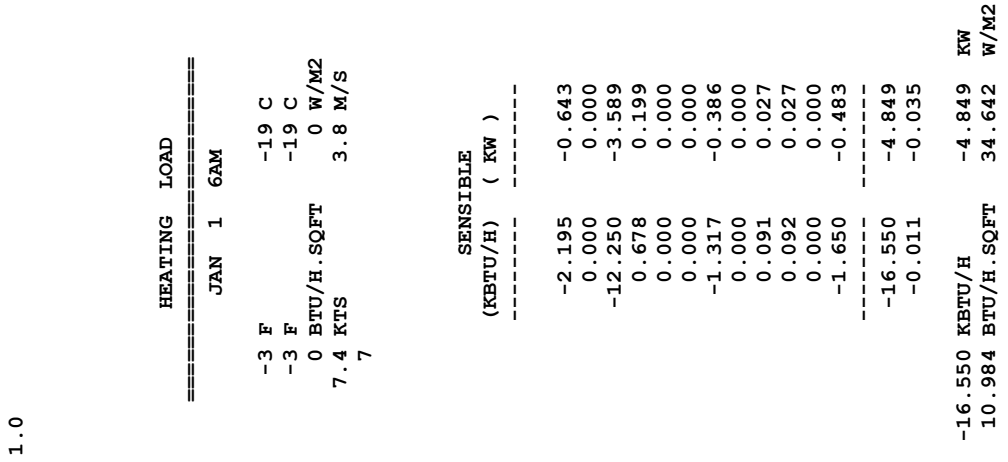

i

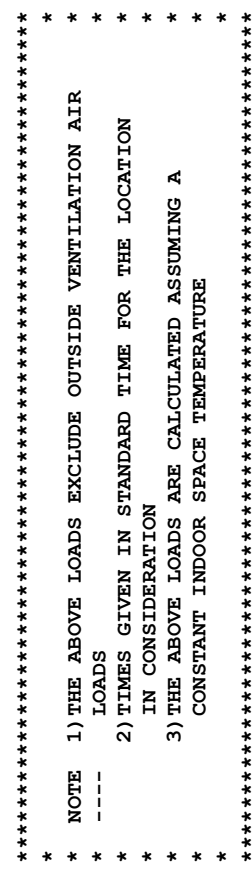

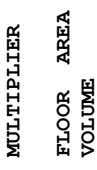
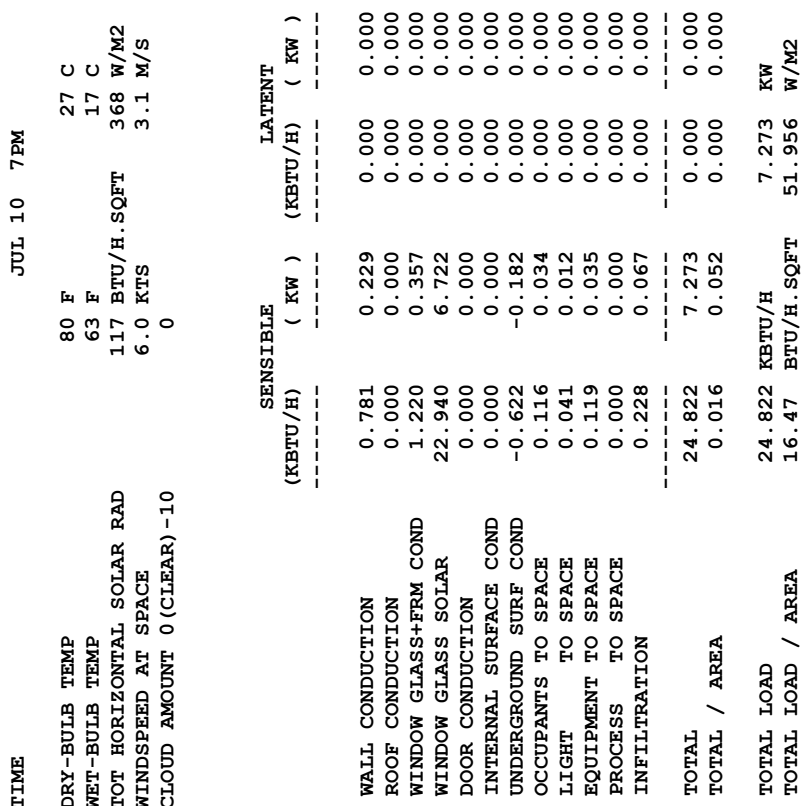


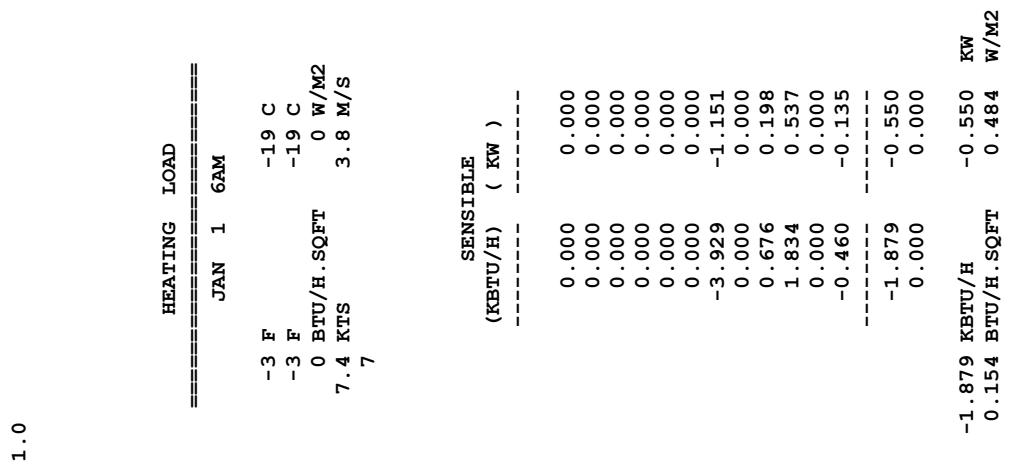

ㅁ

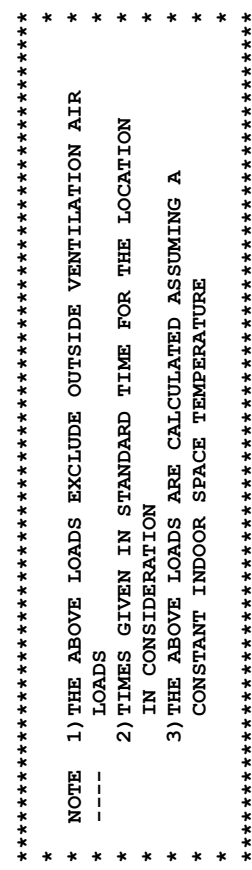

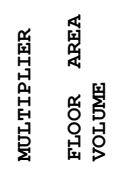
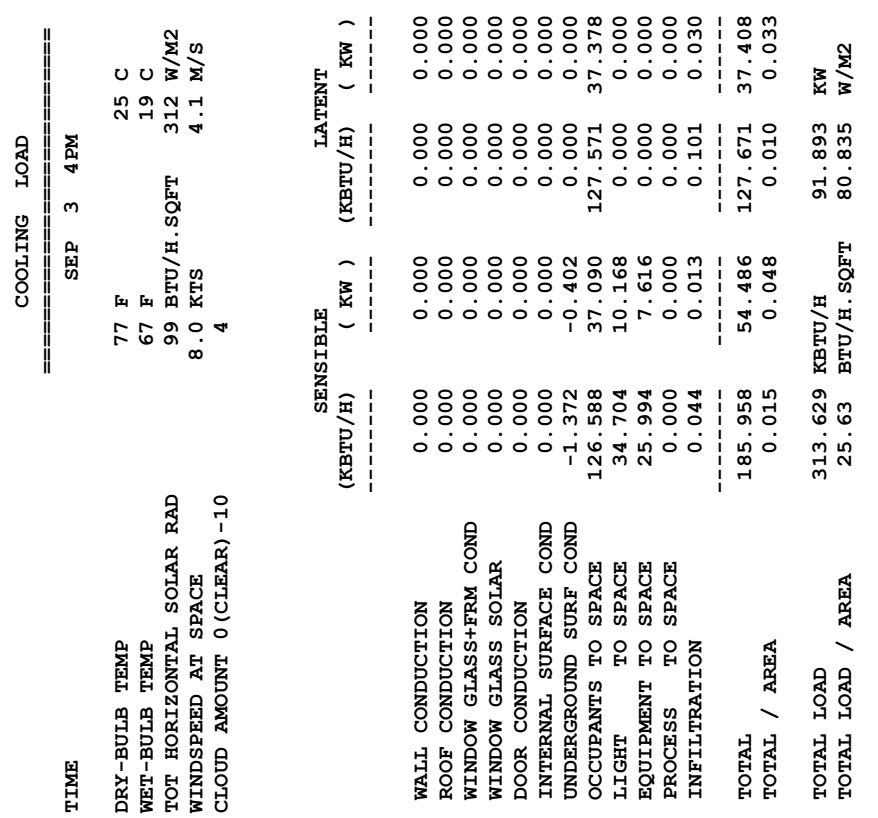


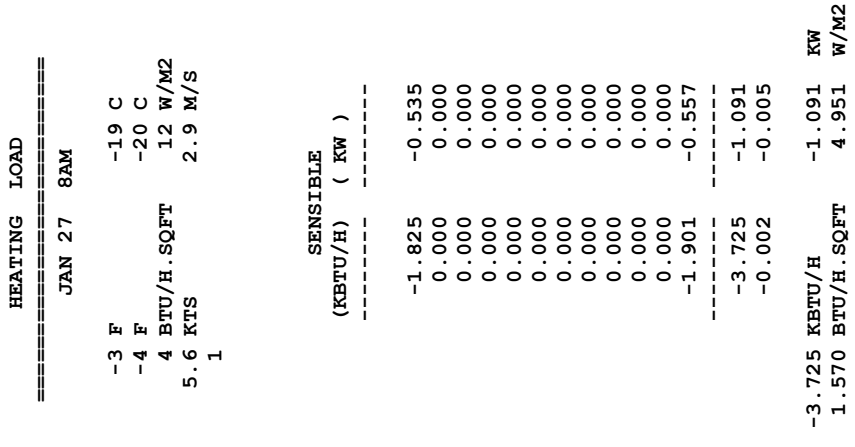

$\stackrel{\circ}{\circ}$

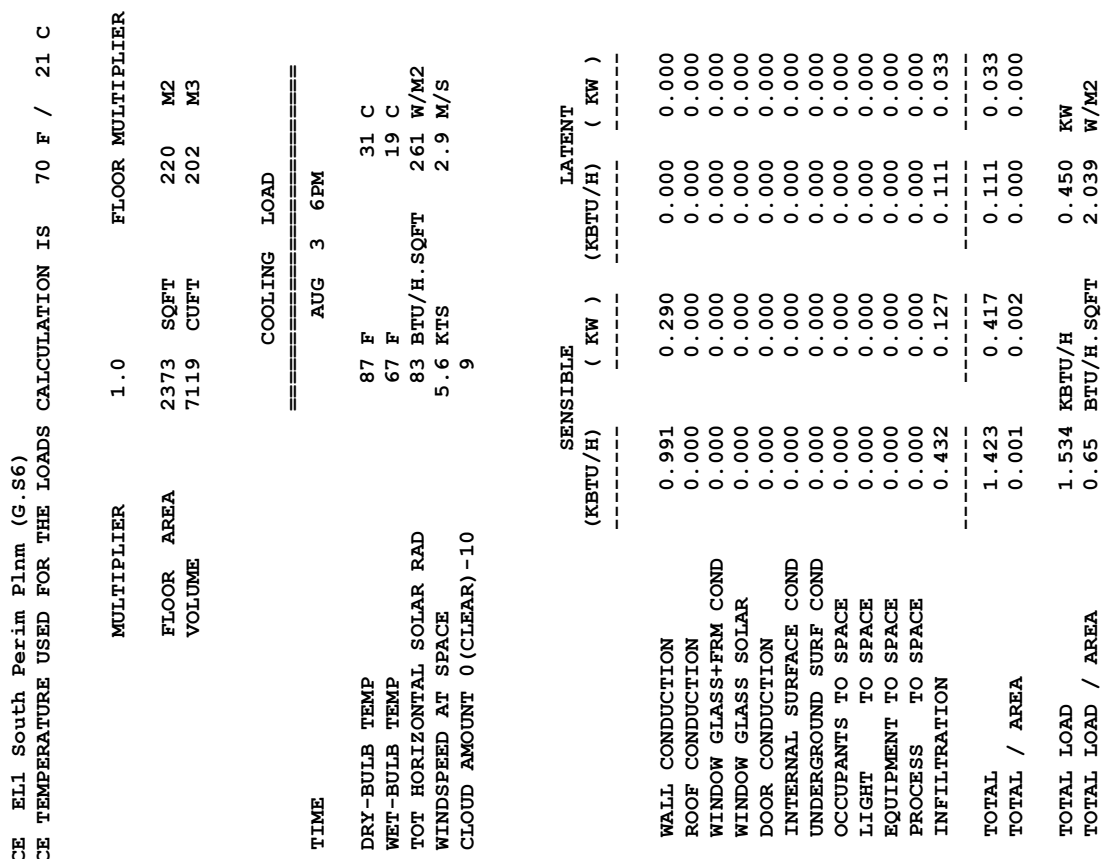




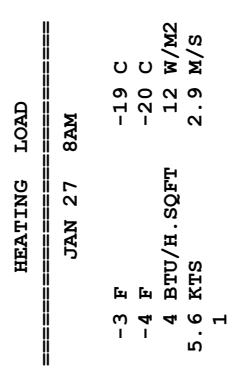

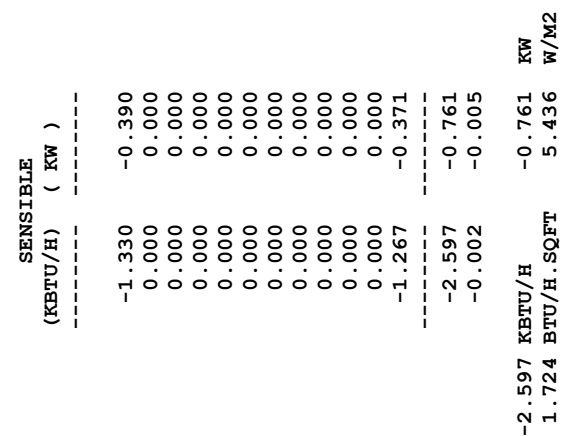

$\stackrel{\circ}{\circ}$

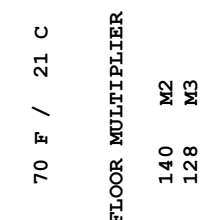

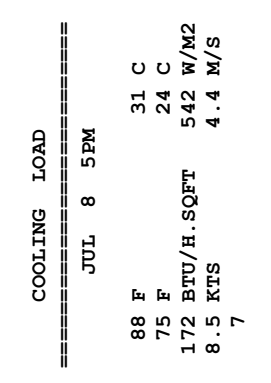
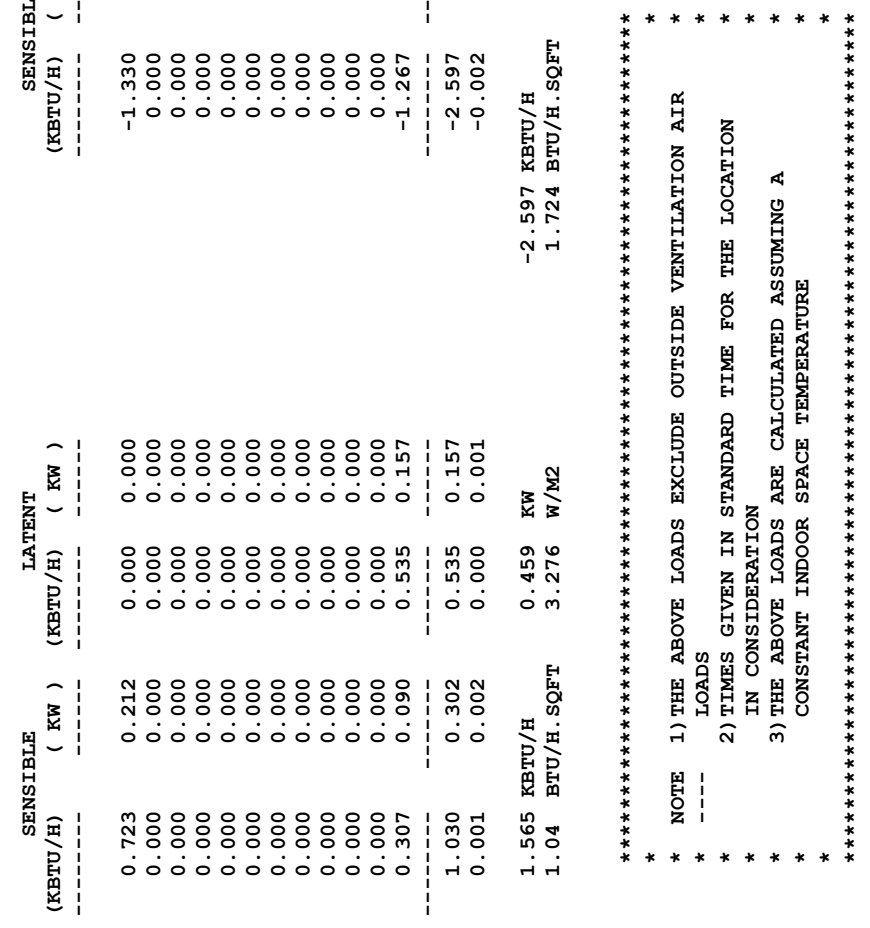

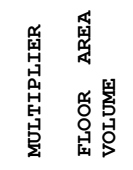
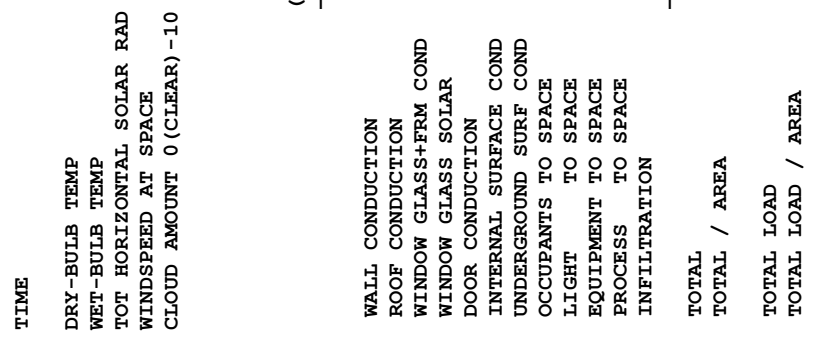


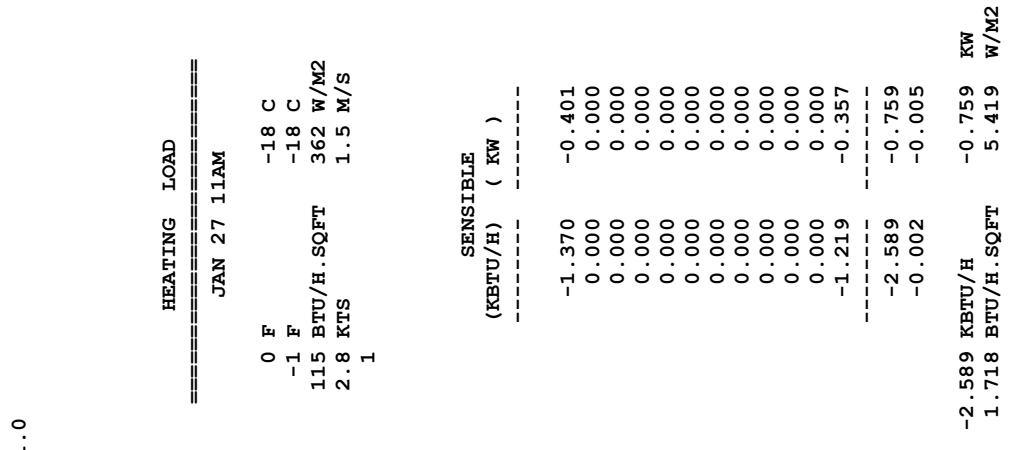

ํ.

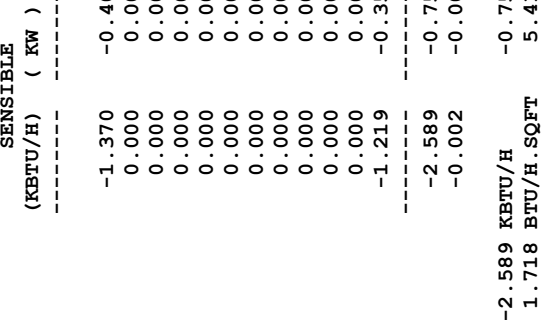




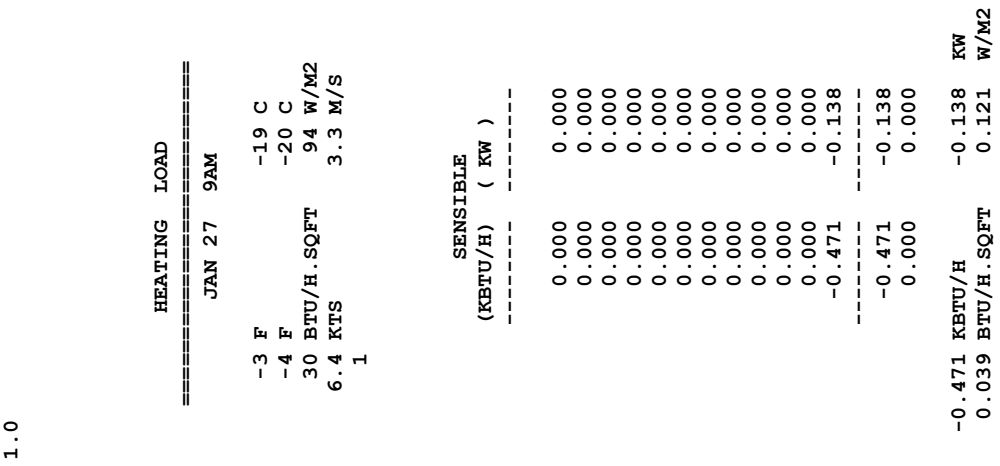

$\stackrel{\circ}{\circ}$

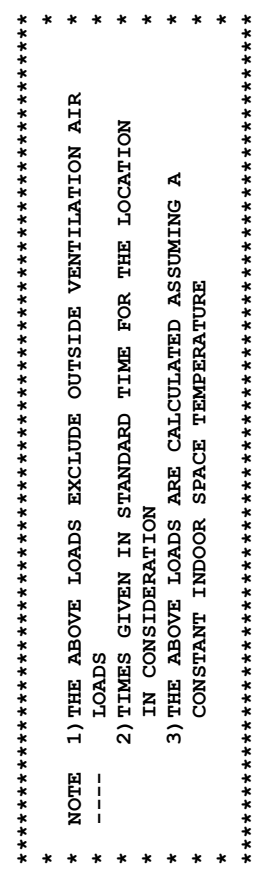

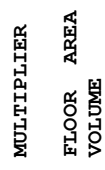
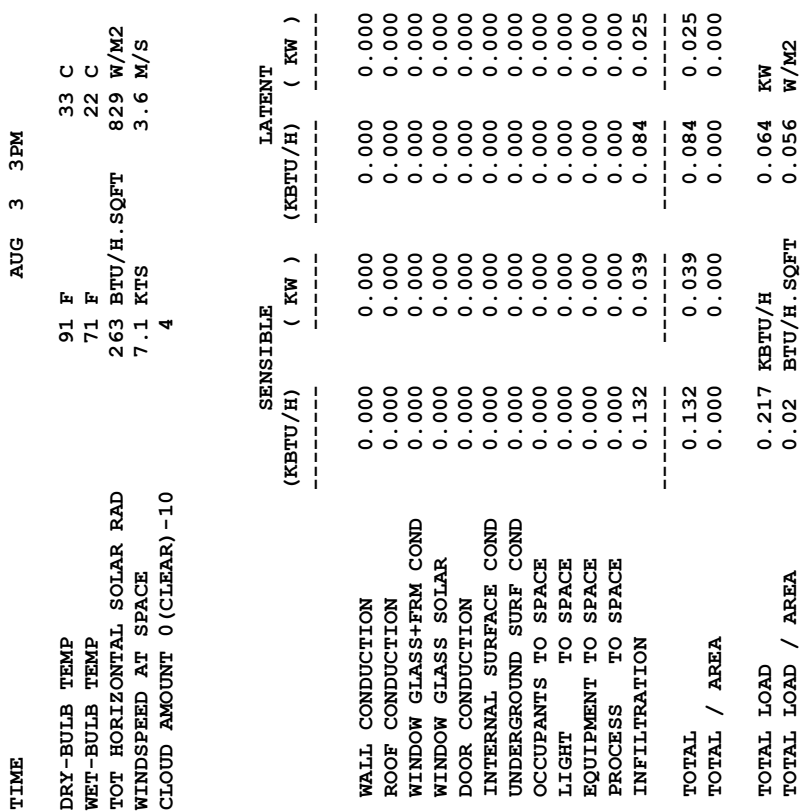

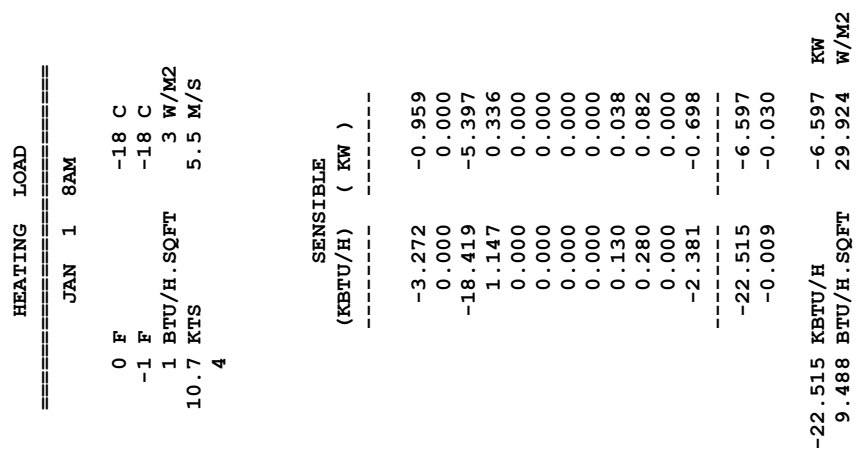

$\stackrel{\circ}{\circ}$

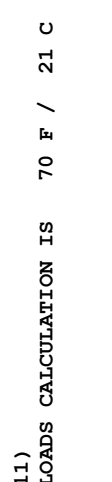

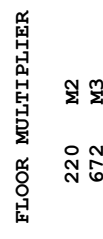

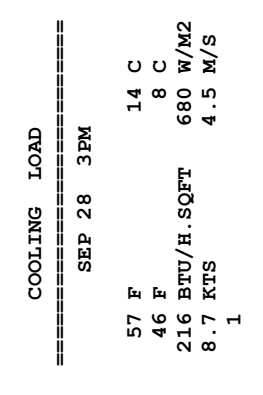

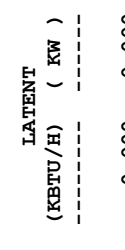

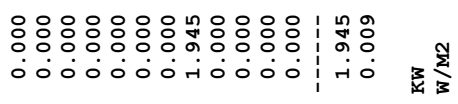

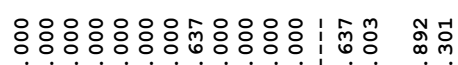

000000000000

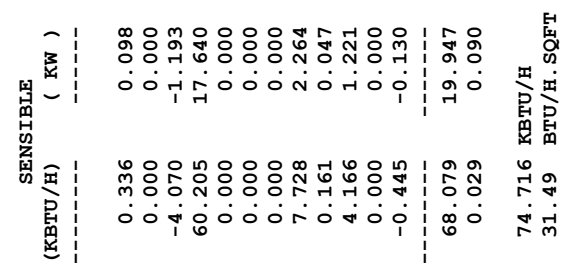

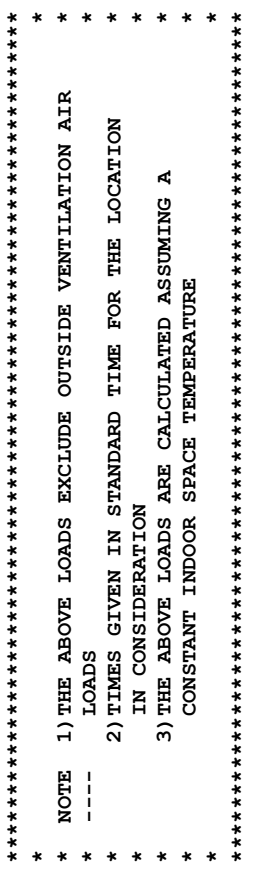

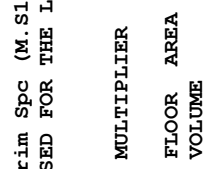
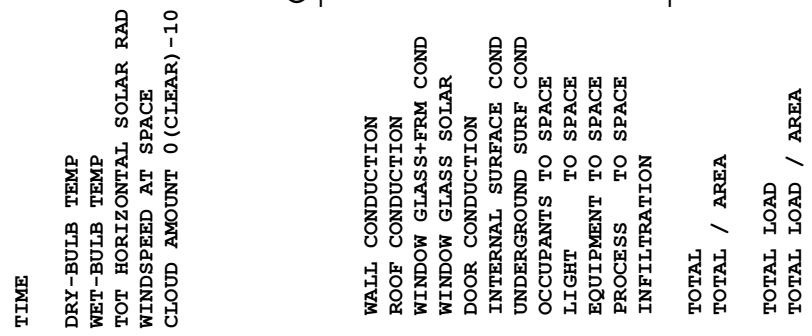


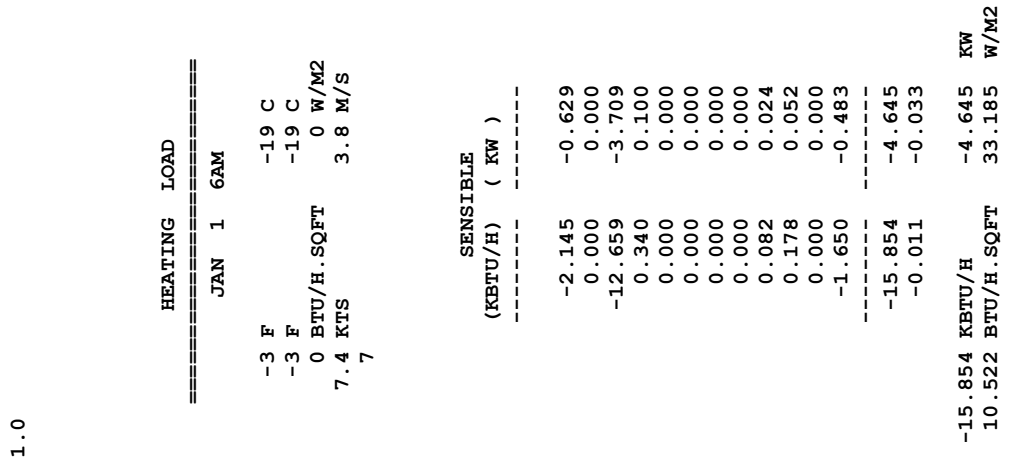

뭉

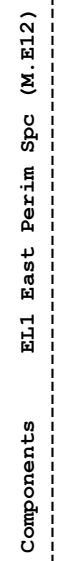

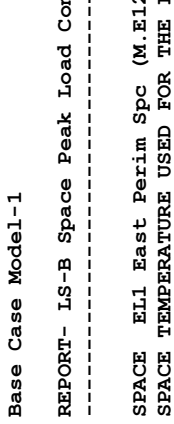
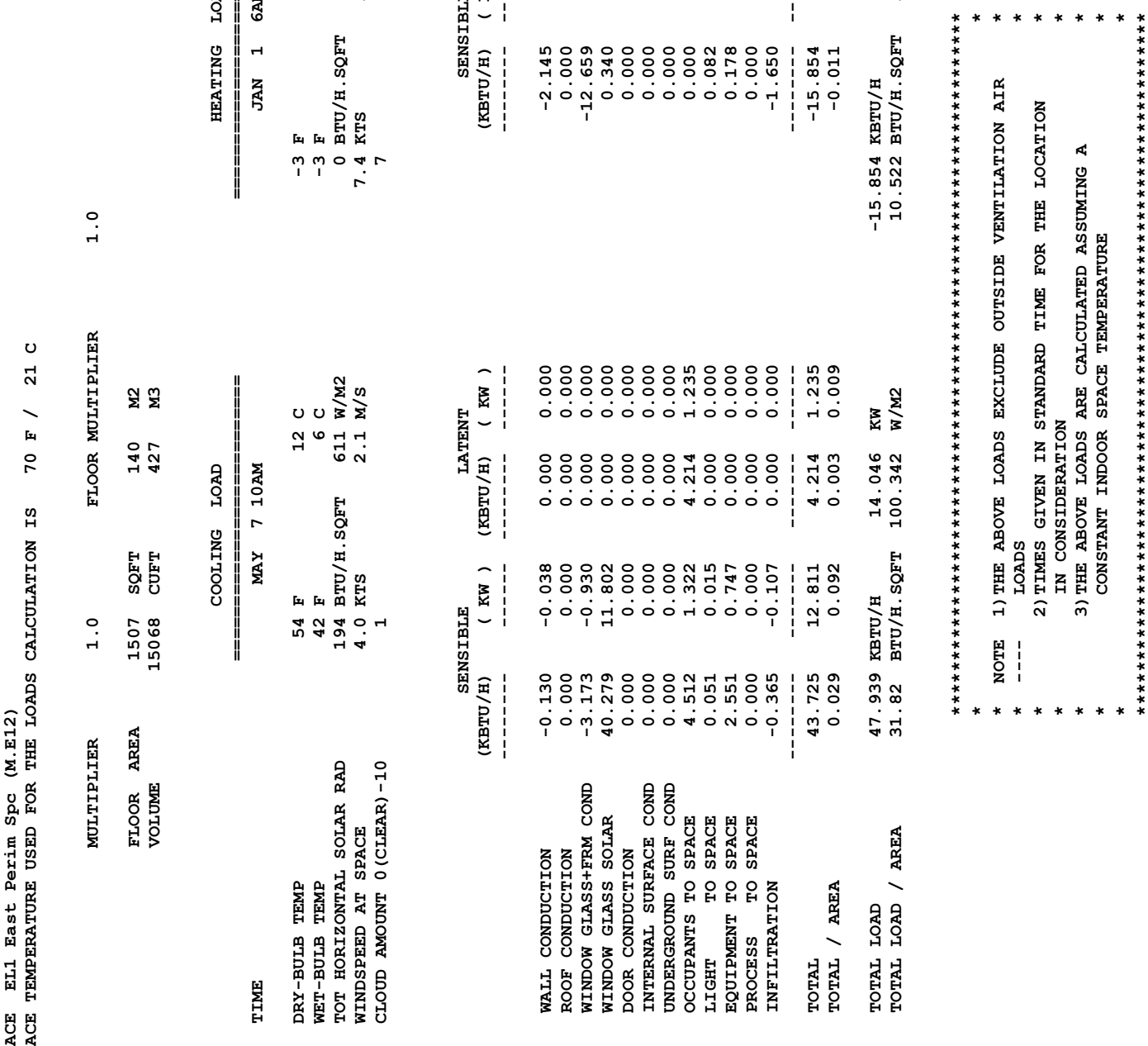


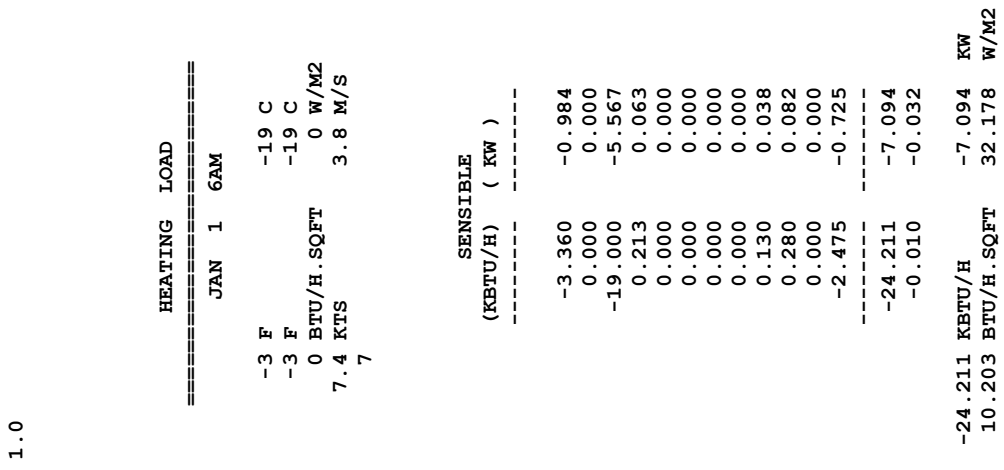

ำ

为

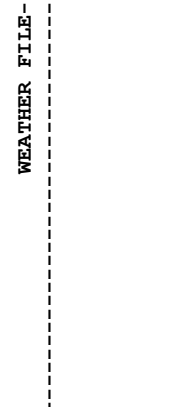

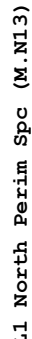

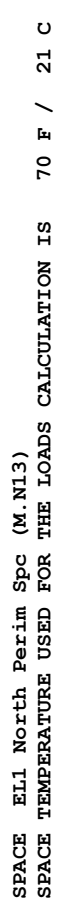

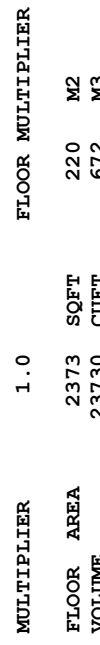

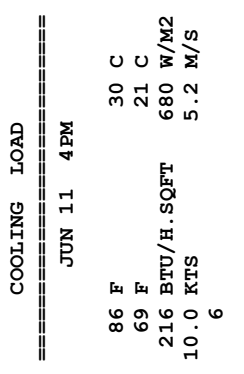

鼻要:

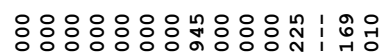

000000040000

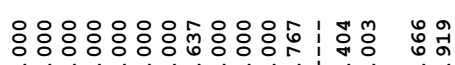

00000000000

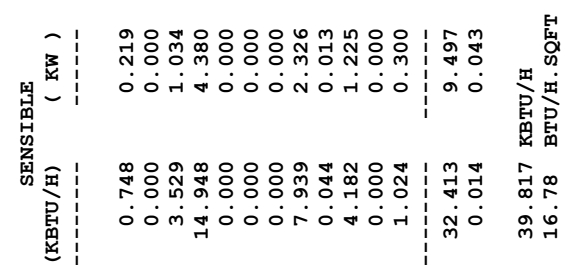
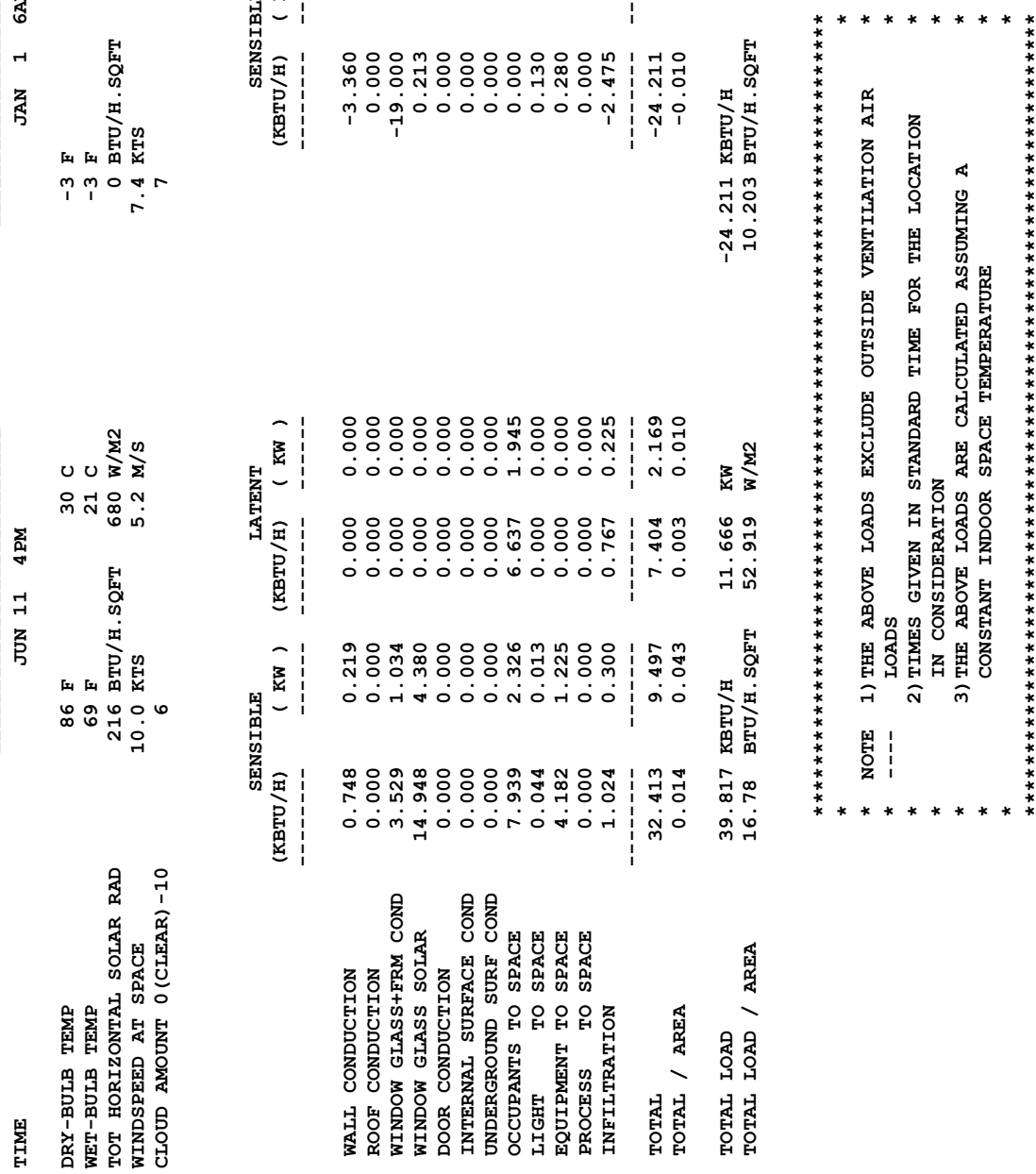


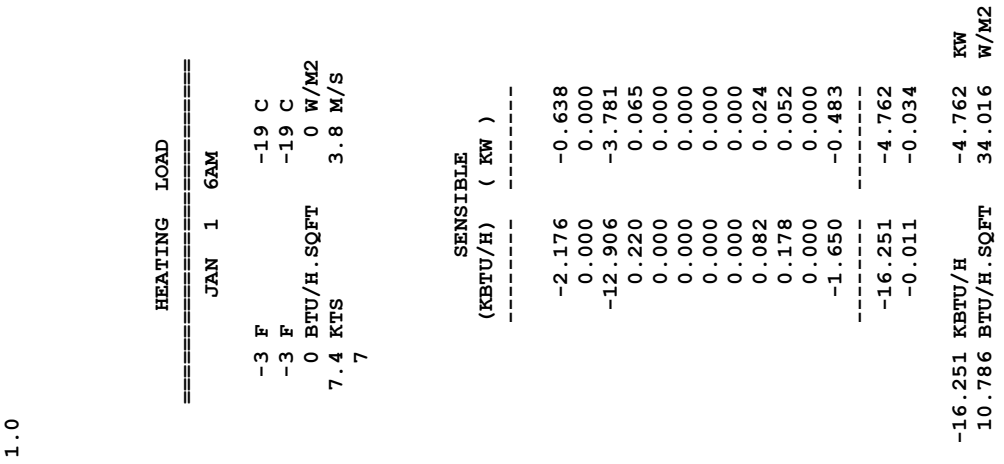

ㅁ

皮

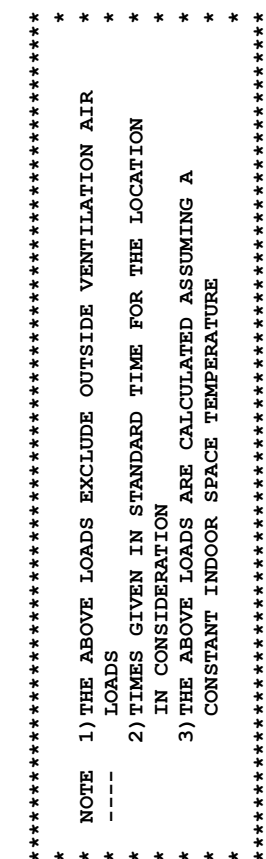

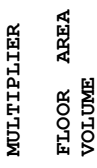
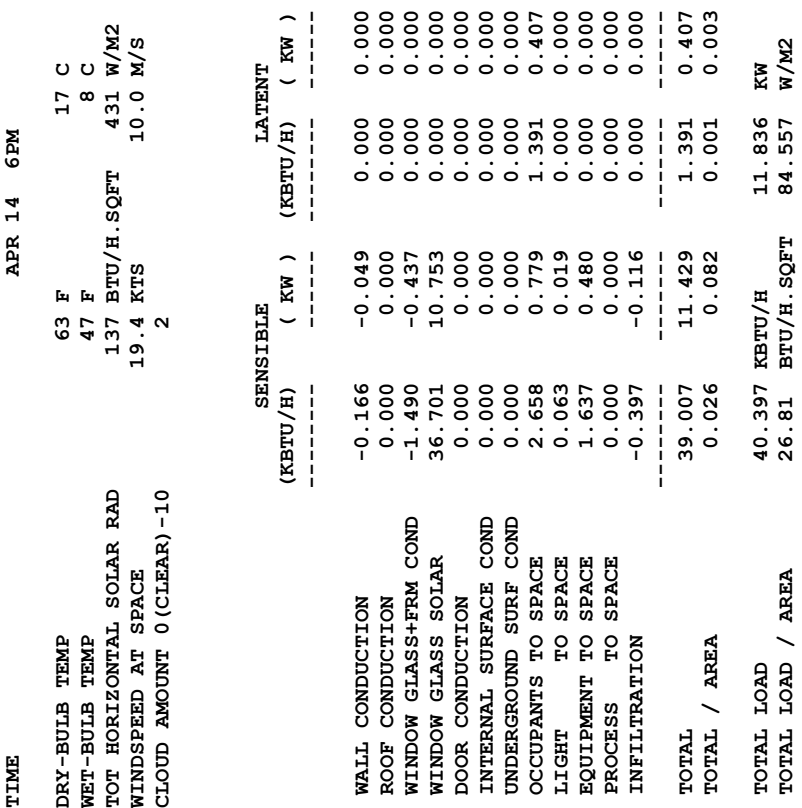


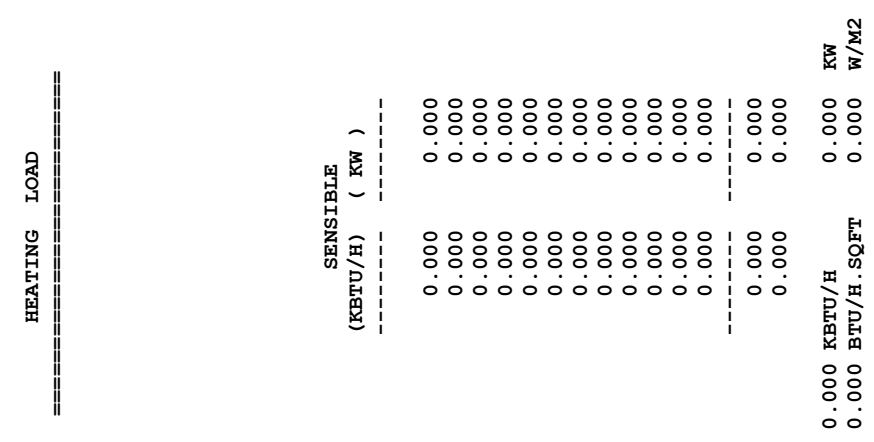

$\stackrel{\circ}{\circ}$

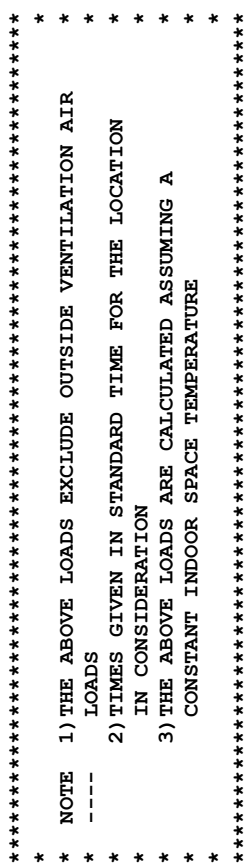

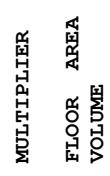
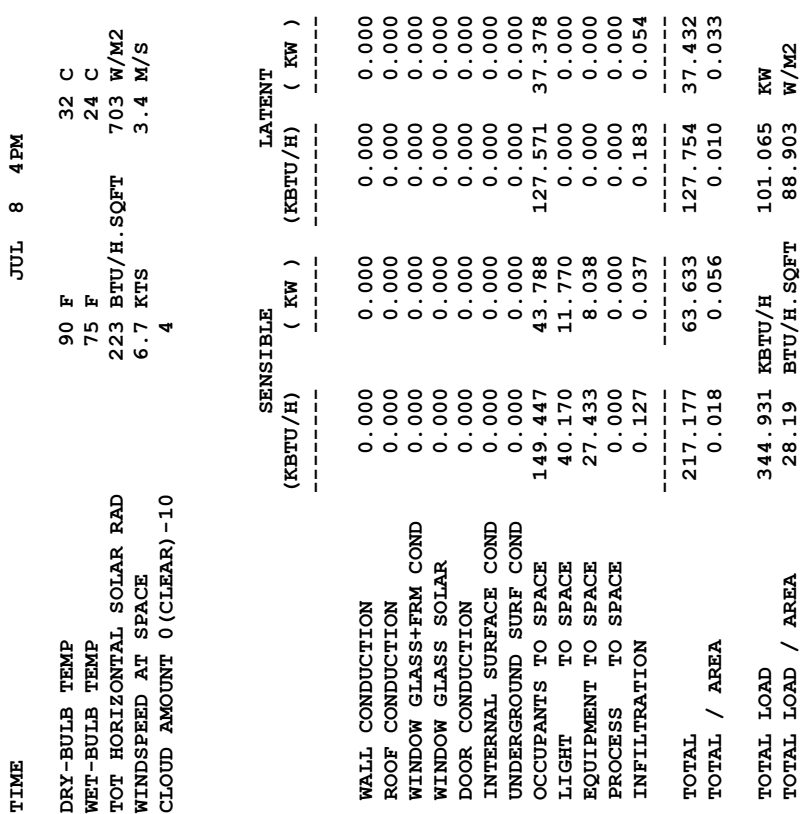


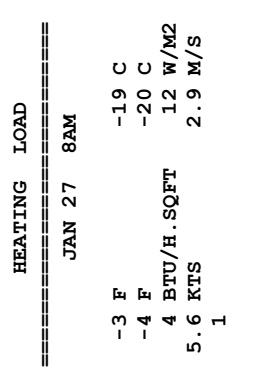

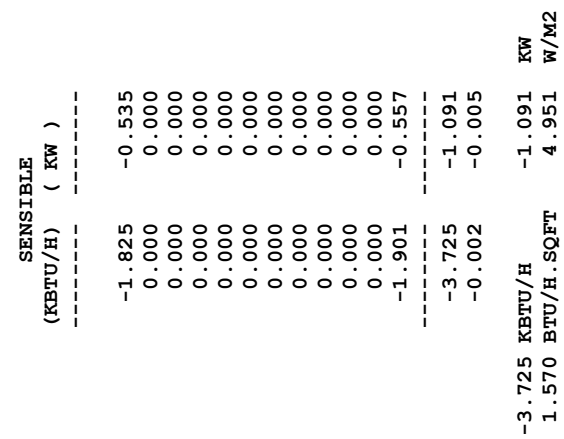

$\stackrel{\circ}{\circ}$

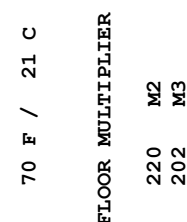

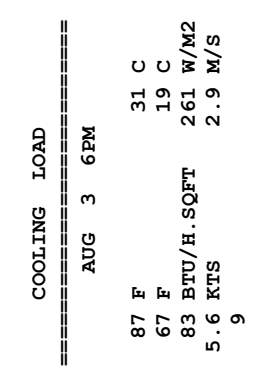
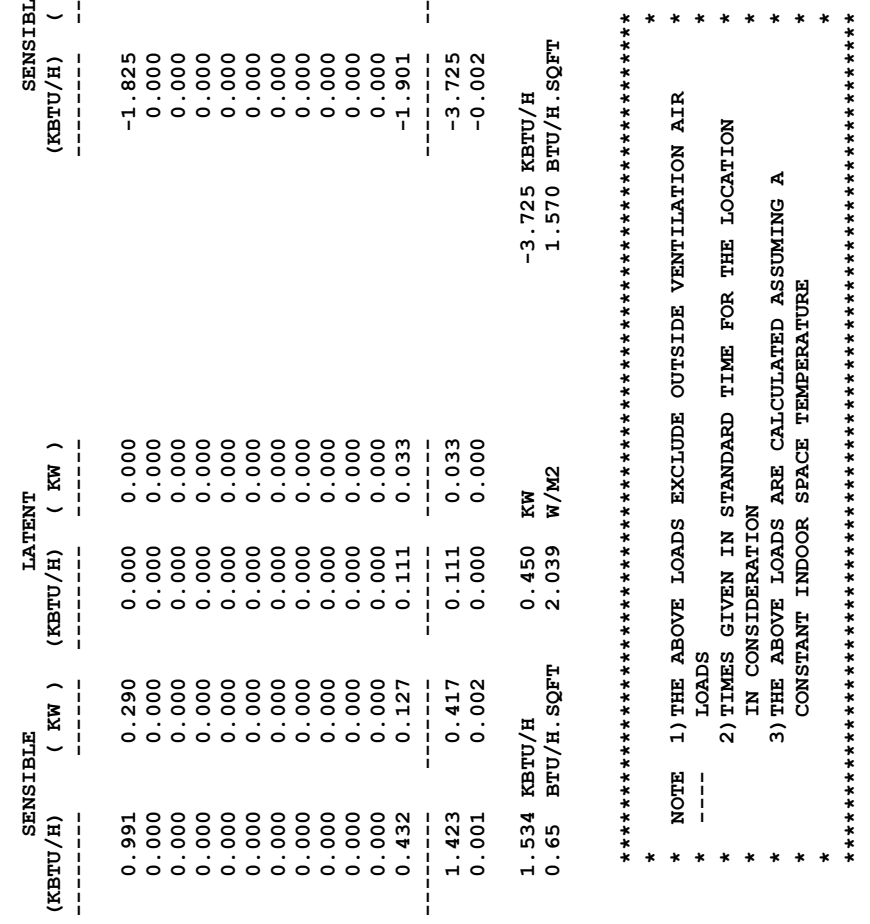

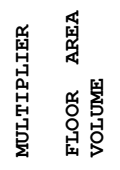
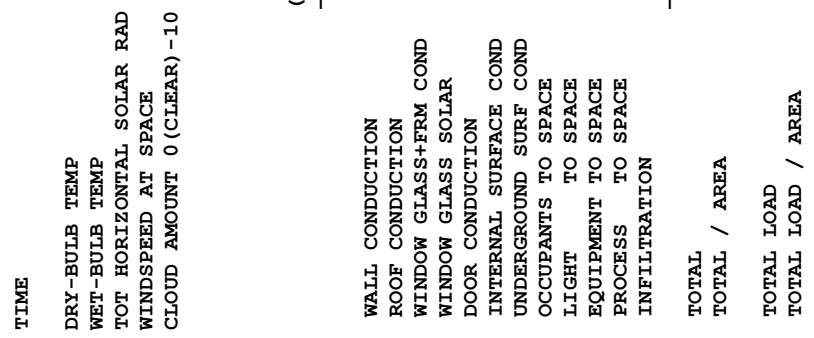


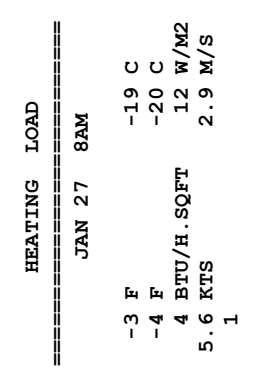

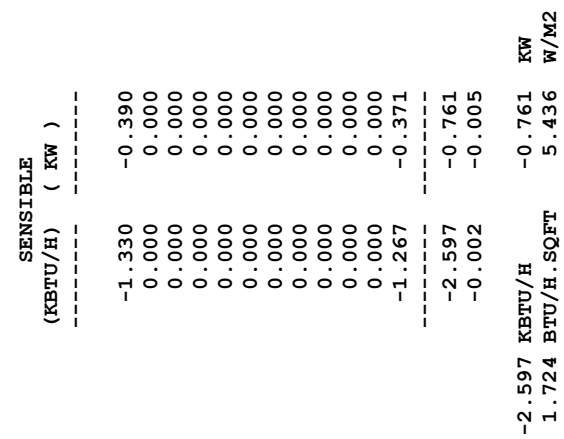

i

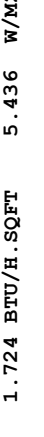




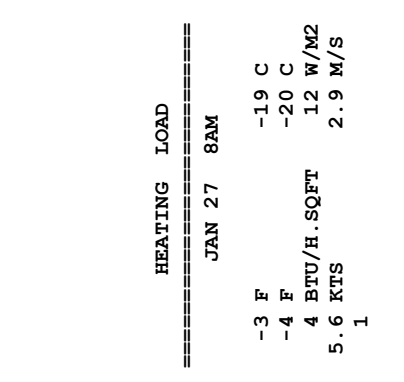

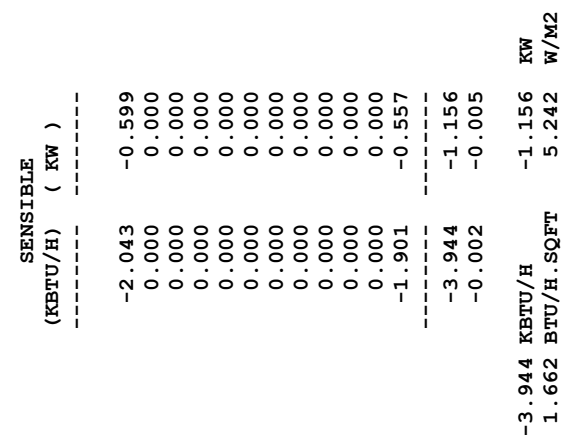

$\stackrel{\circ}{i}$

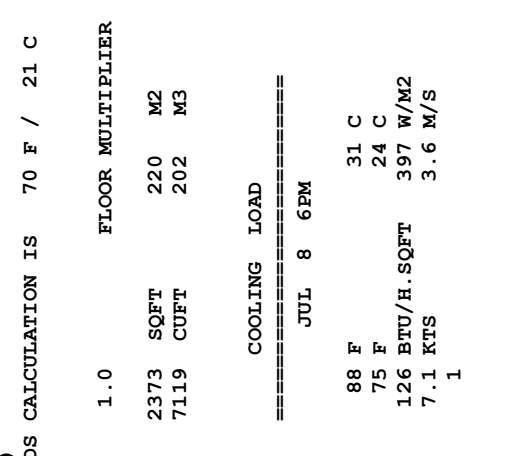
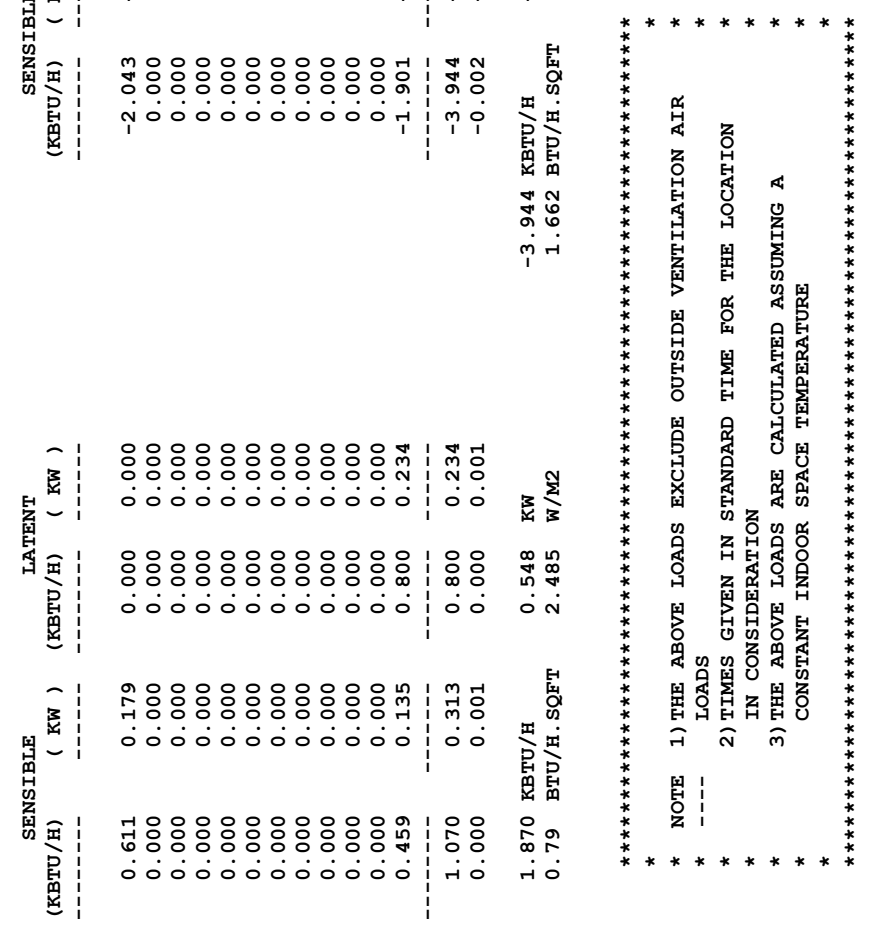

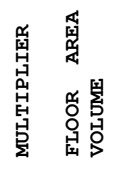
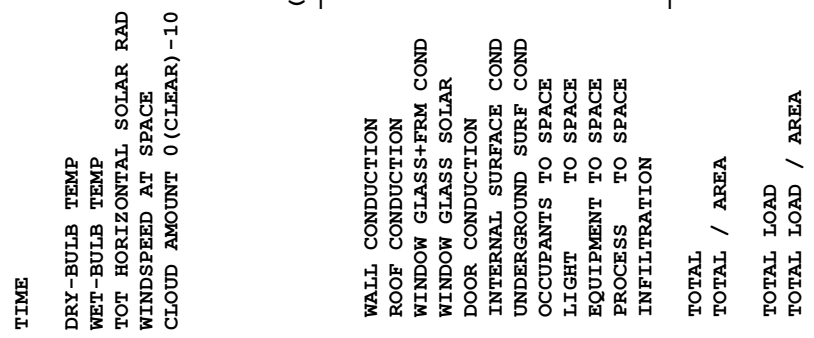


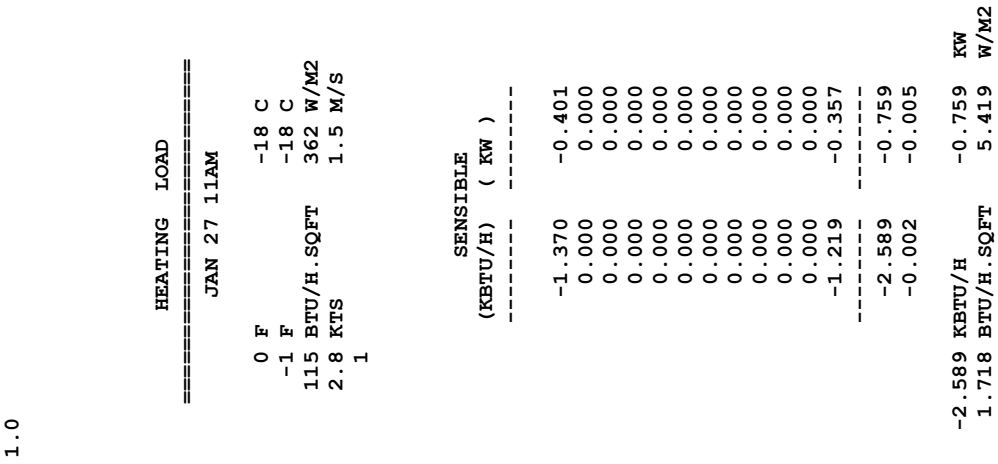

ํ.
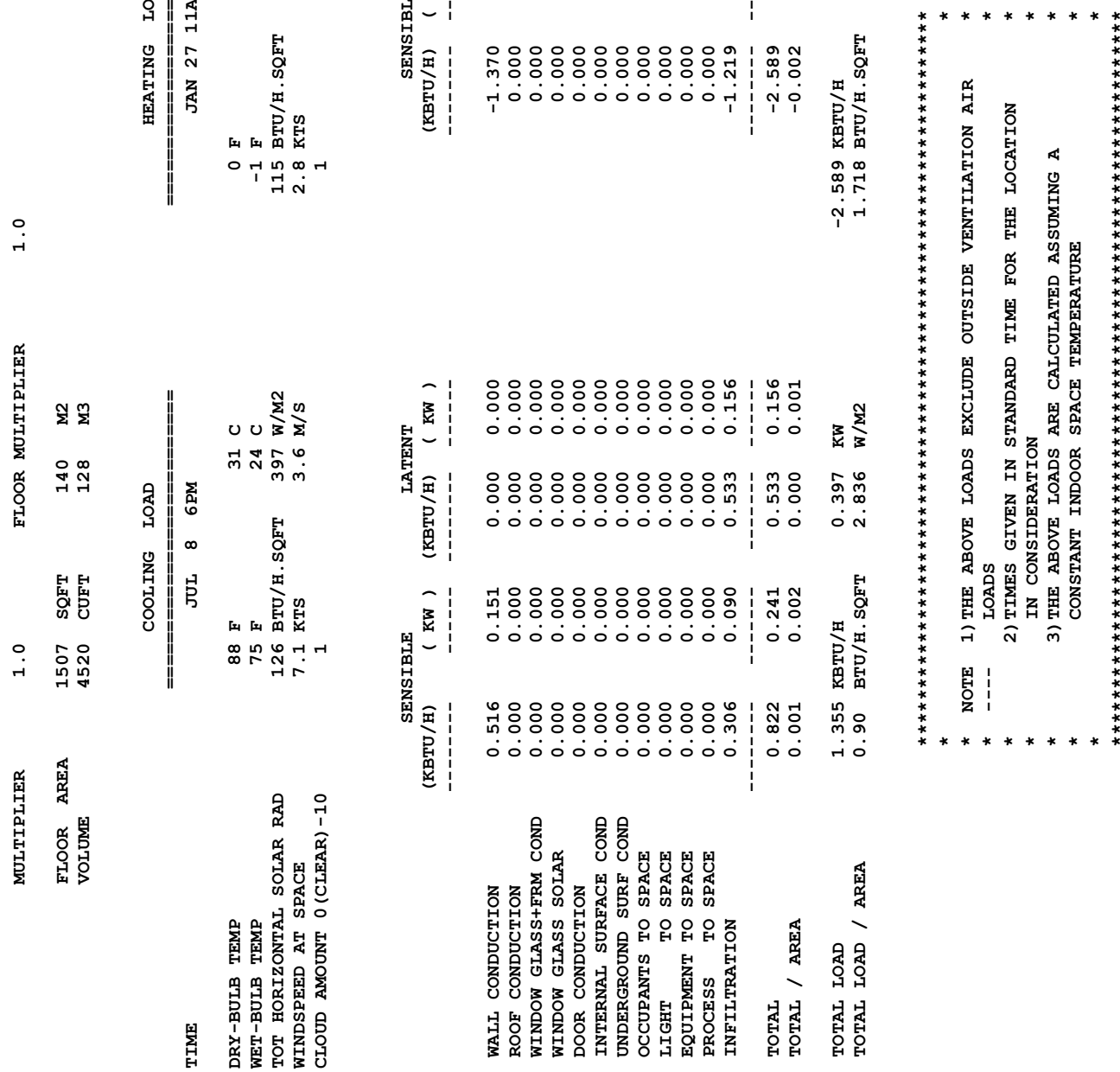


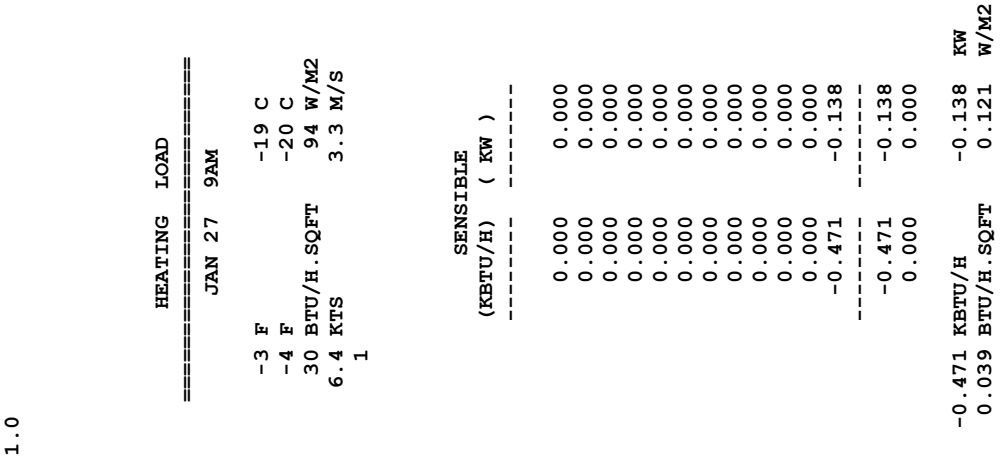

$\stackrel{\circ}{\circ}$

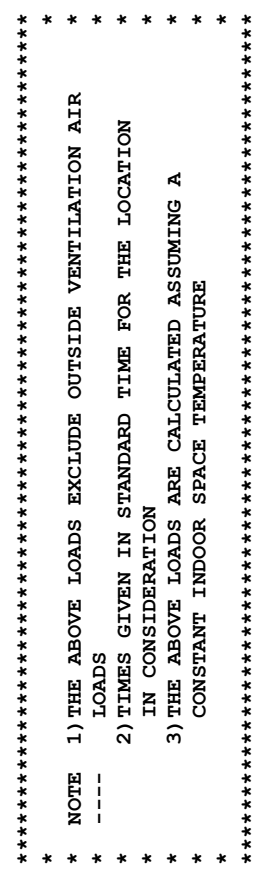

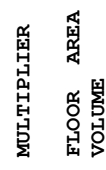
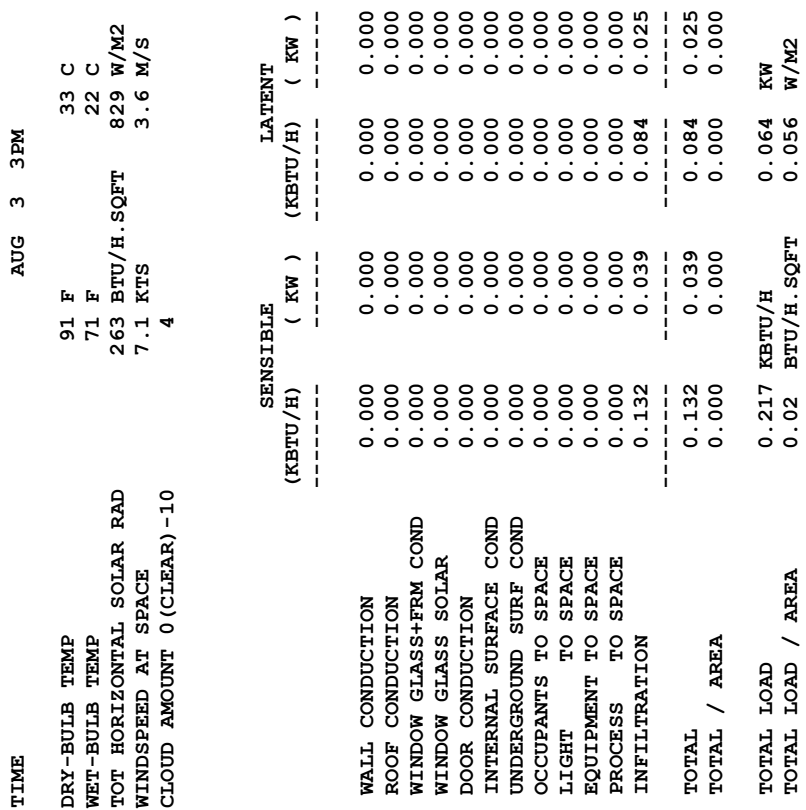

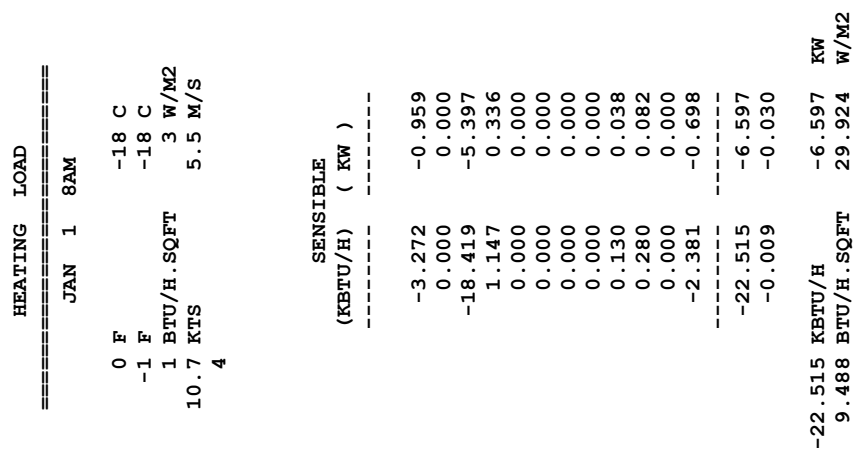

$\stackrel{\circ}{\circ}$
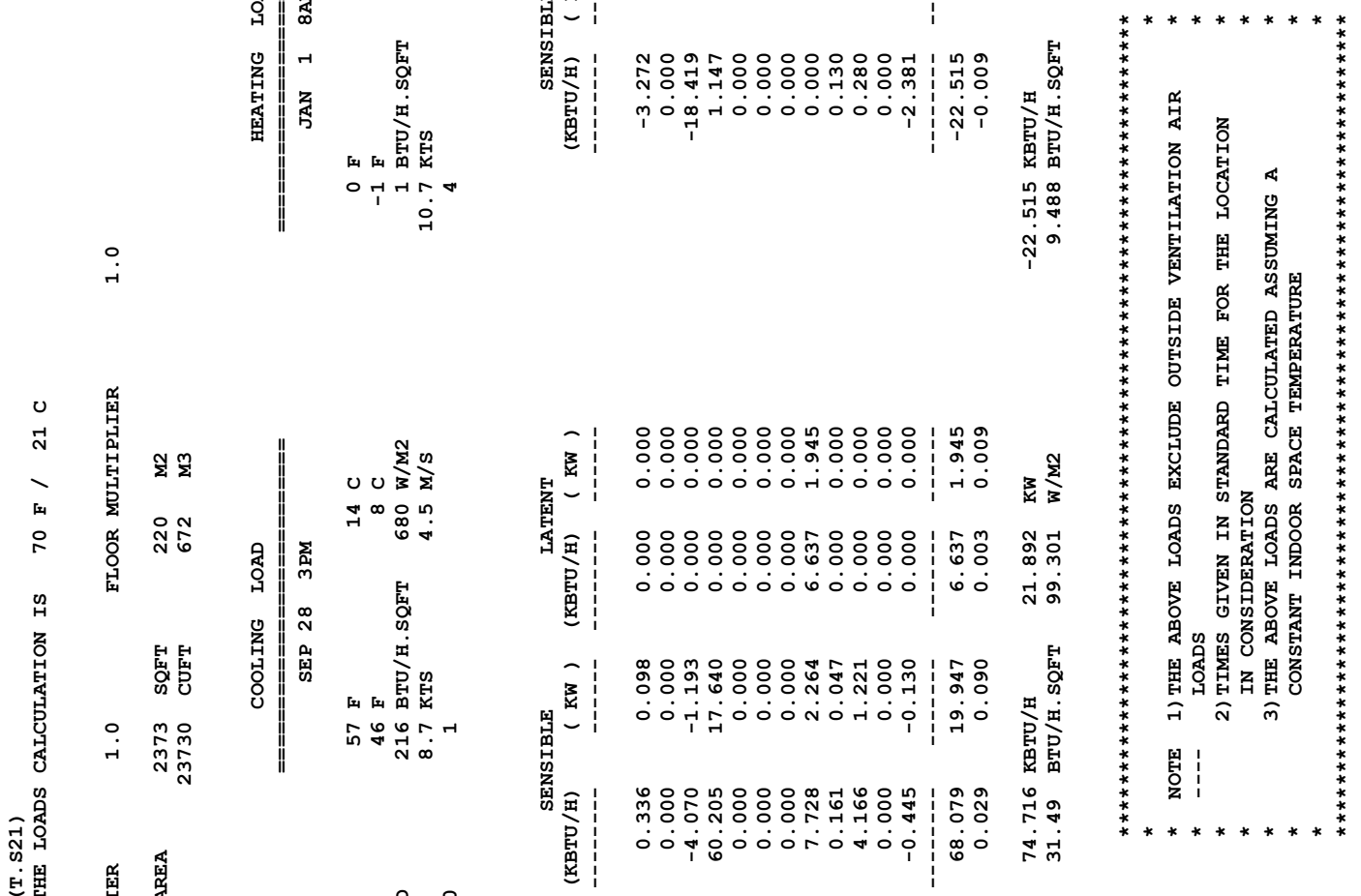

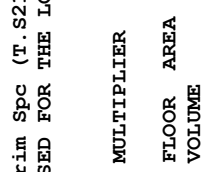
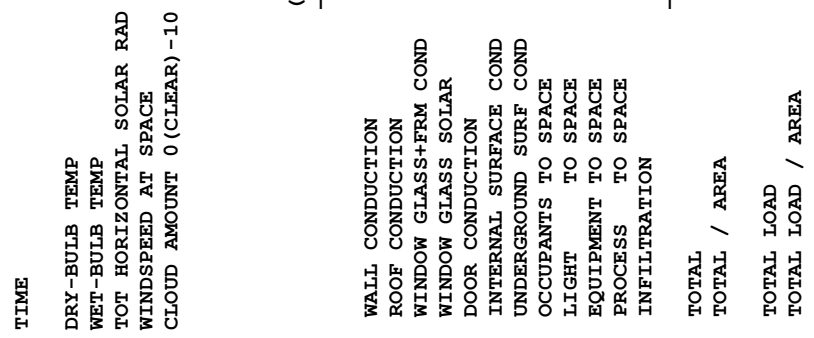


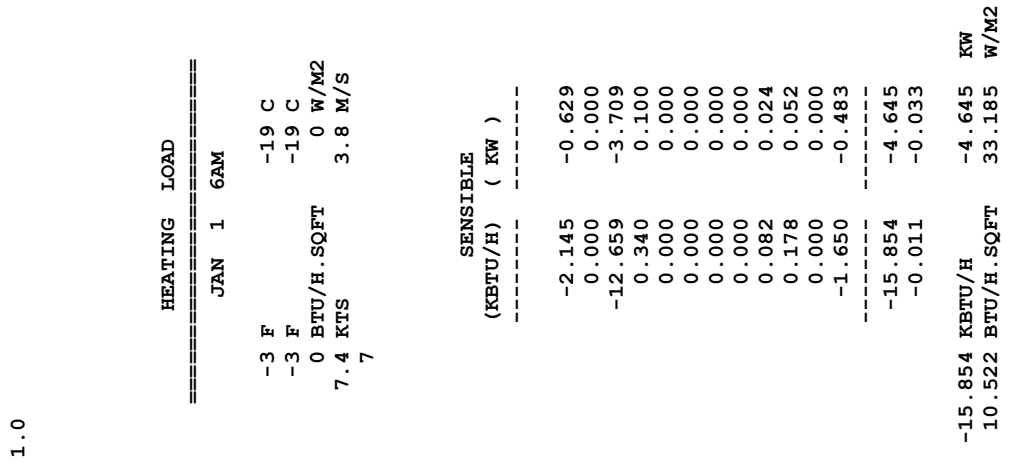

뭉

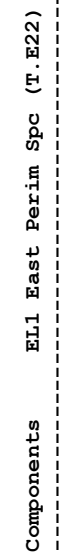

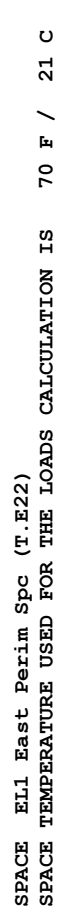

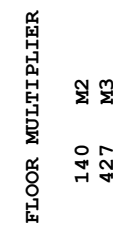

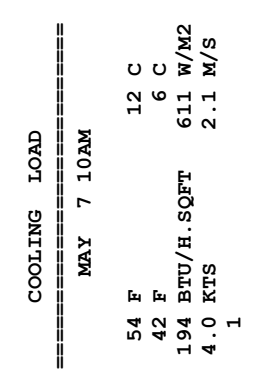
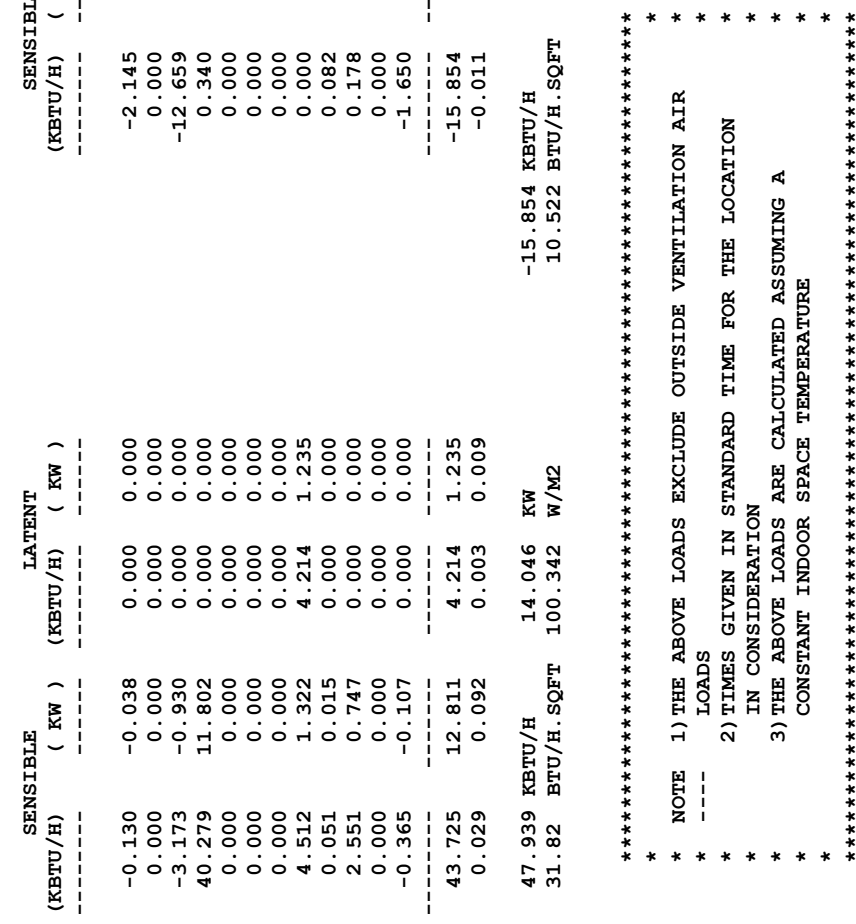

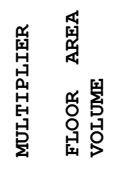
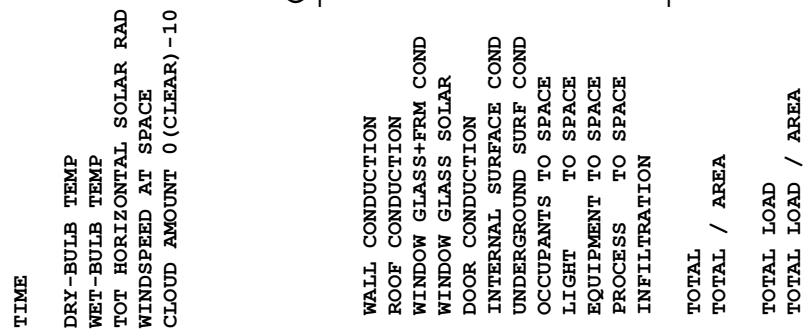

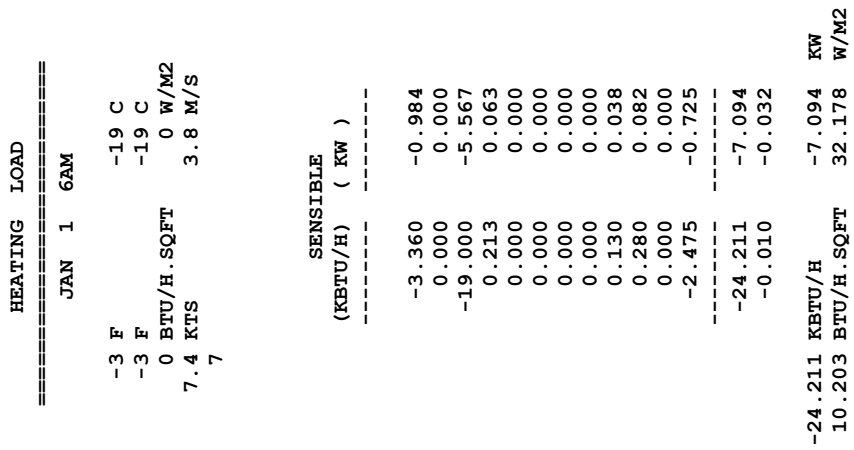

$\stackrel{\circ}{\circ}$
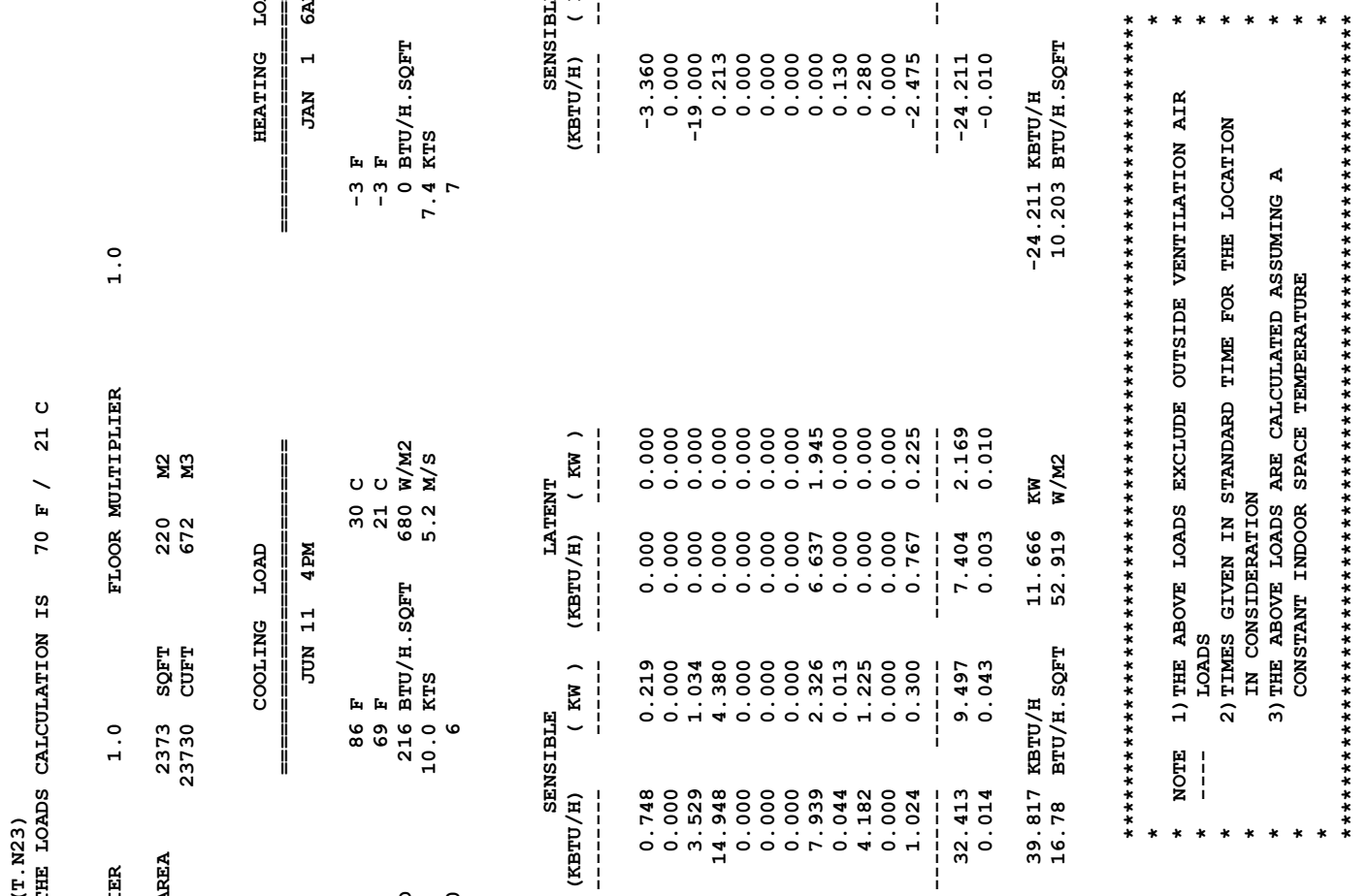

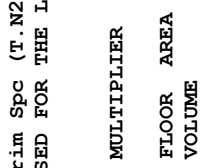
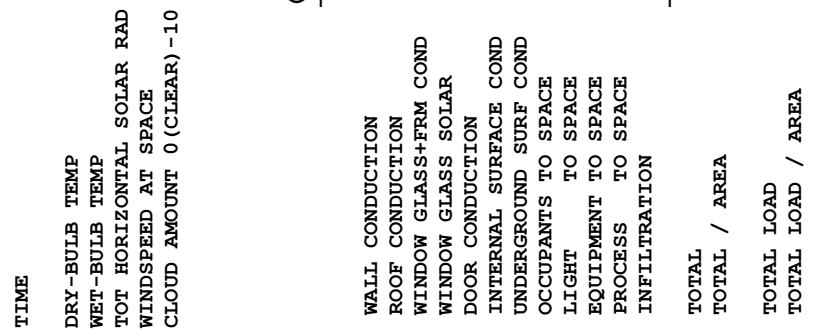


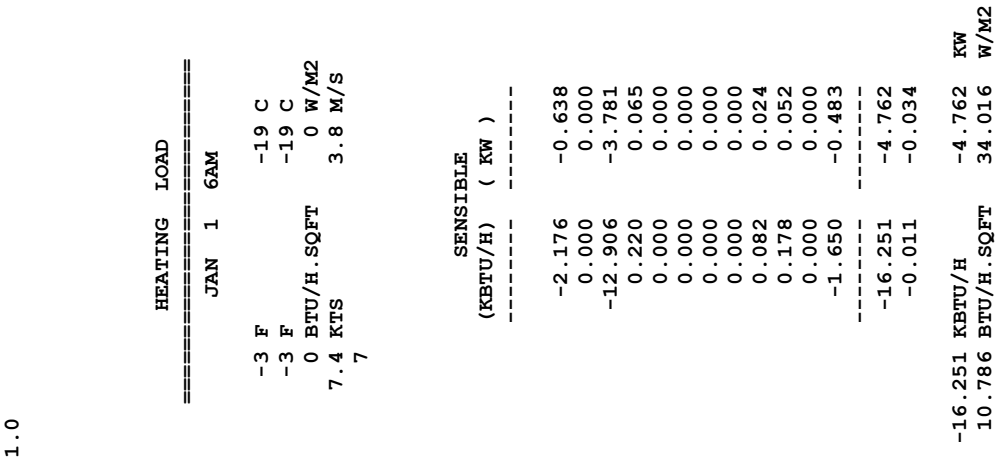

뭉

皮

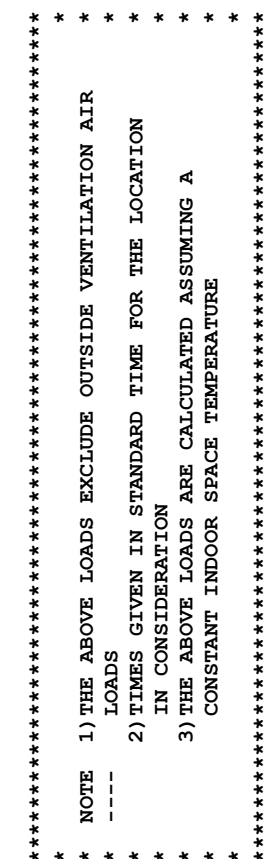

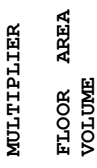
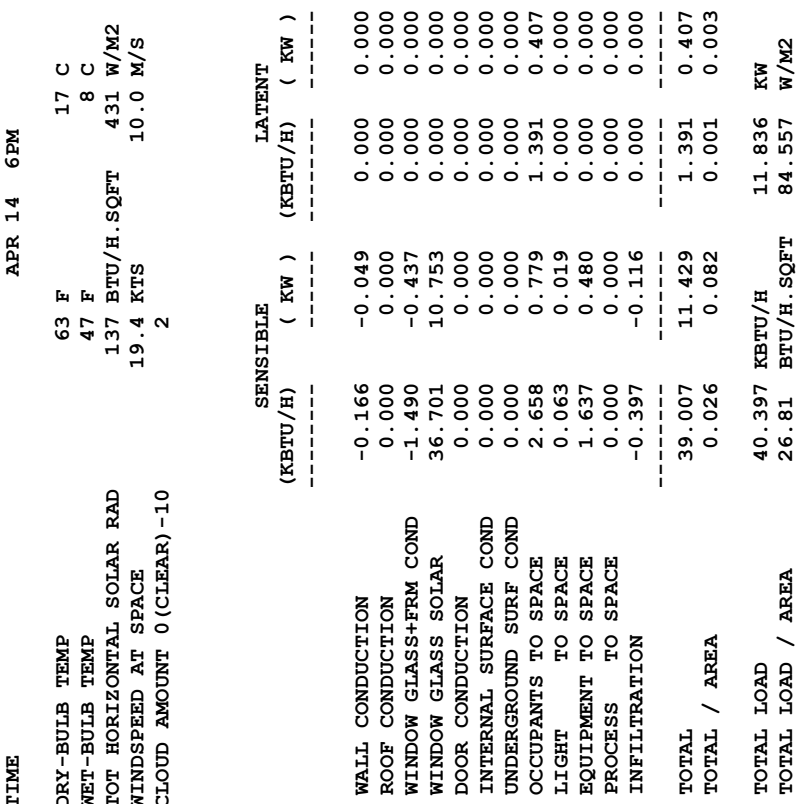


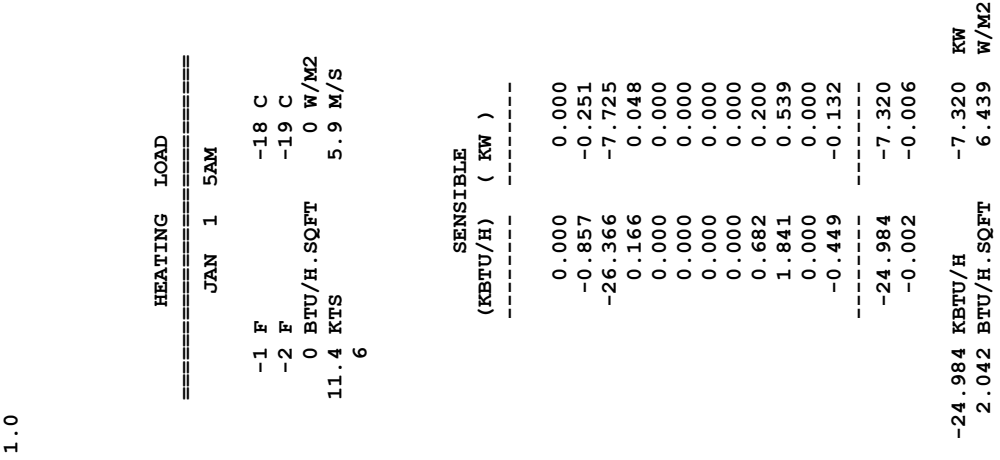

$\stackrel{\circ}{\circ}$

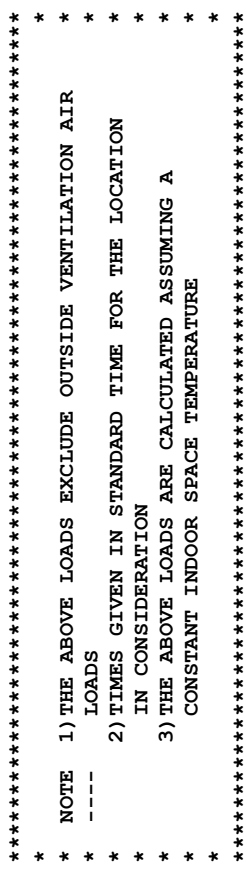

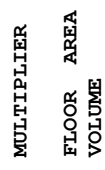
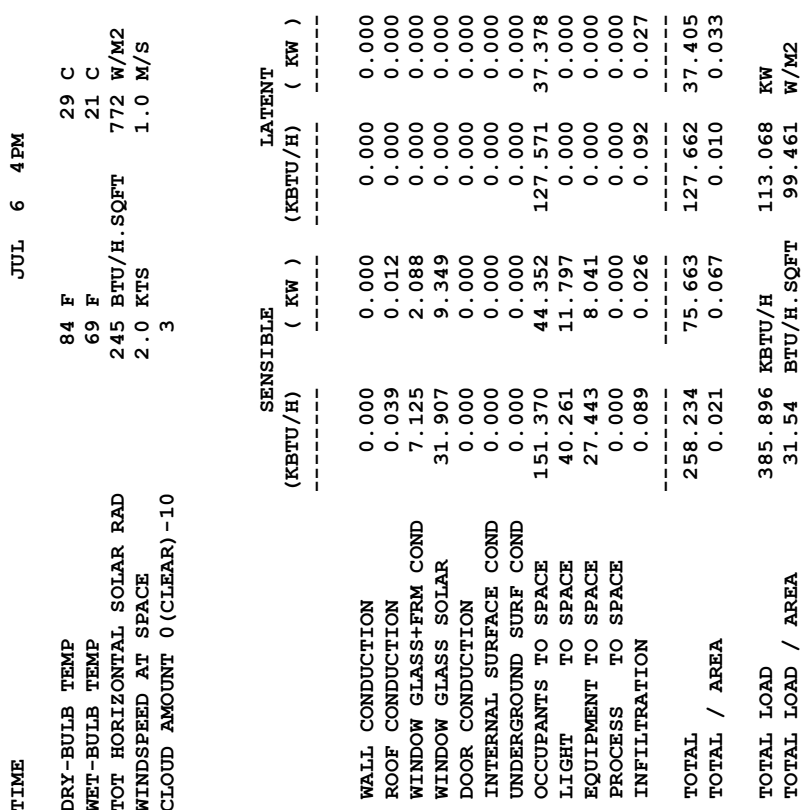


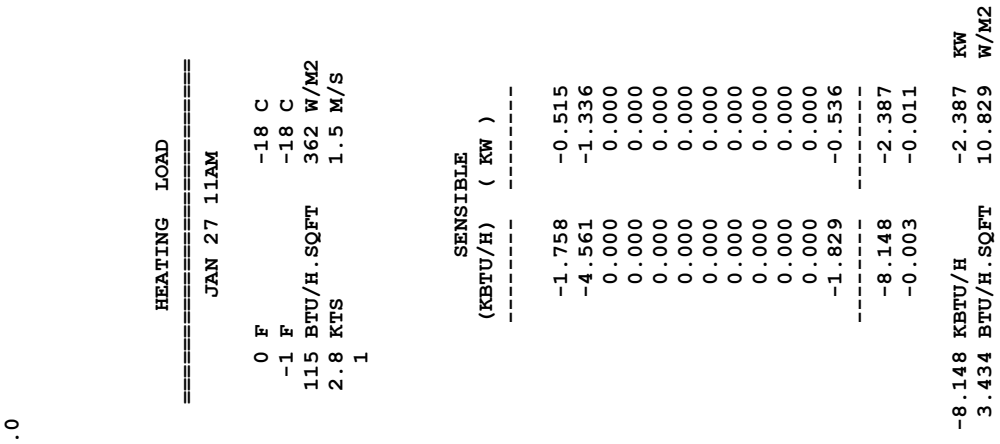

ن
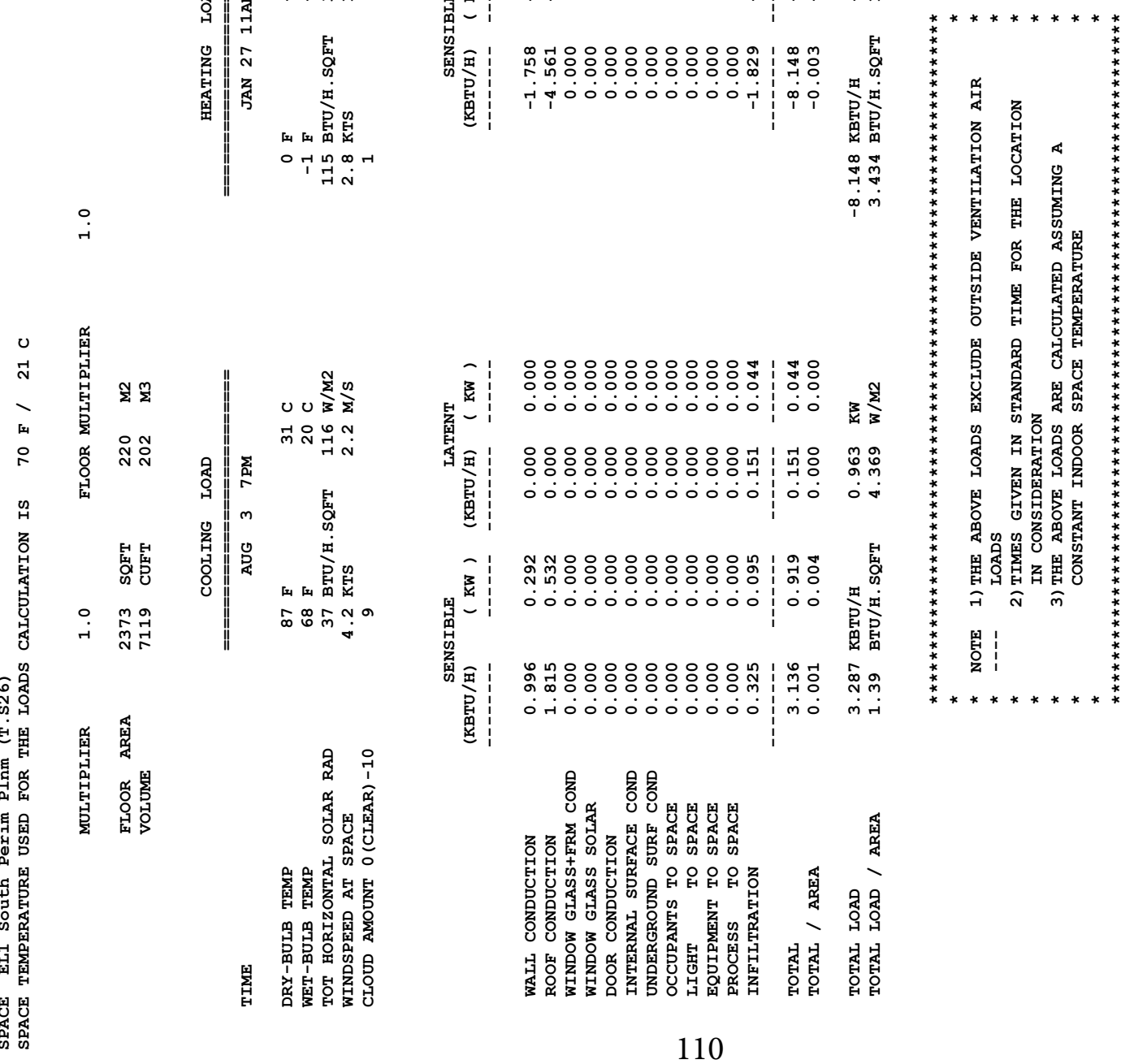


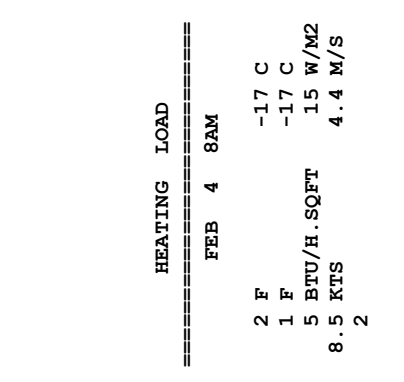

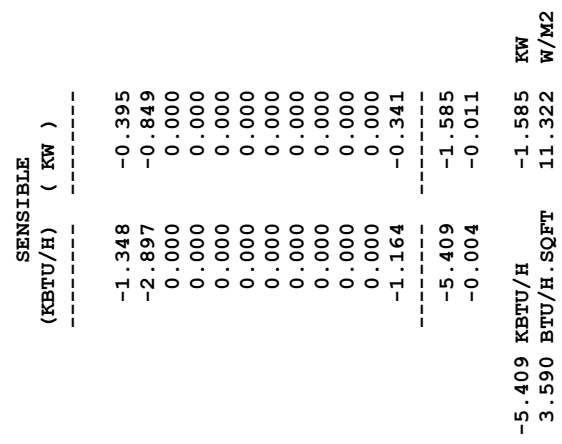

$\stackrel{\circ}{i}$

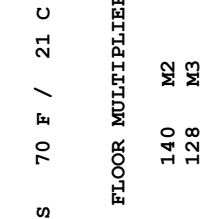

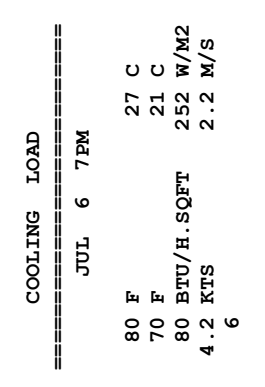
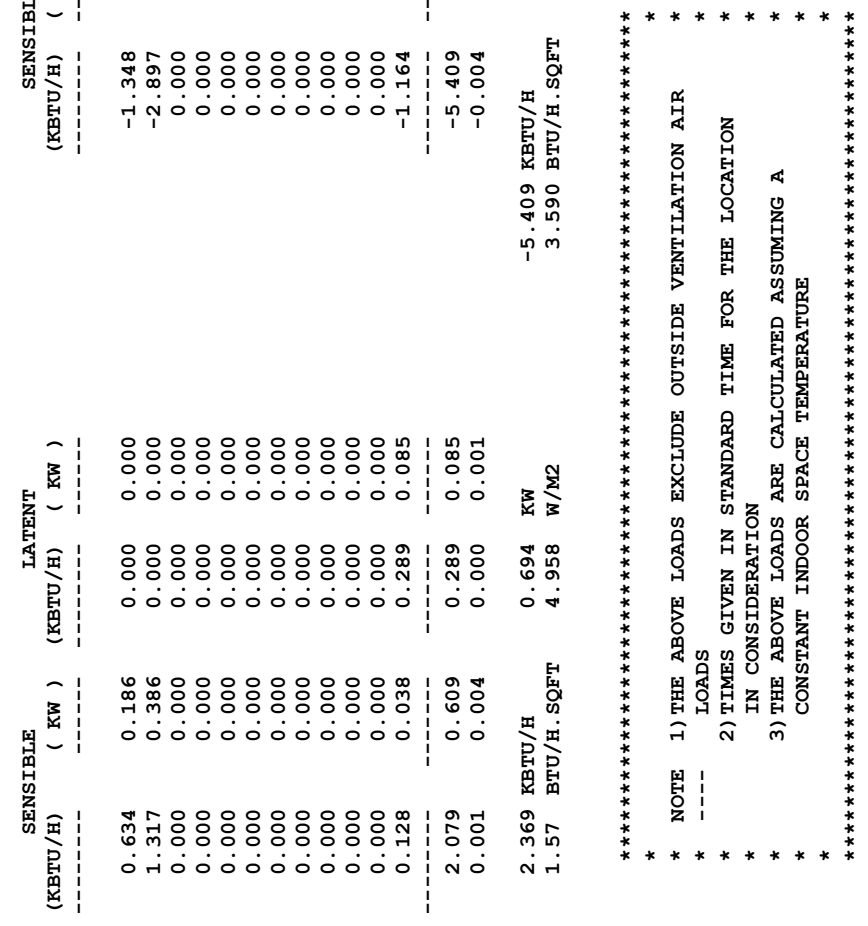

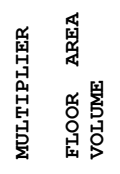
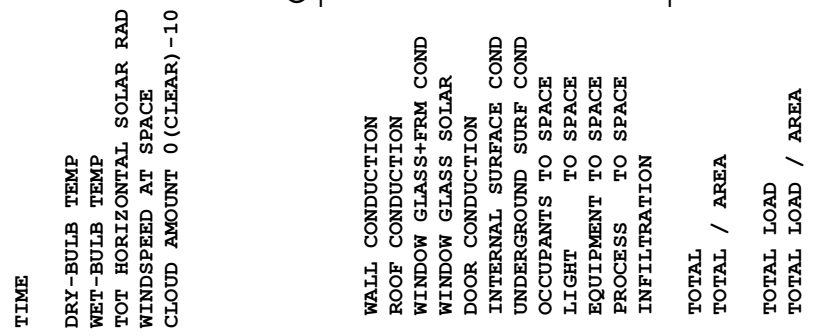


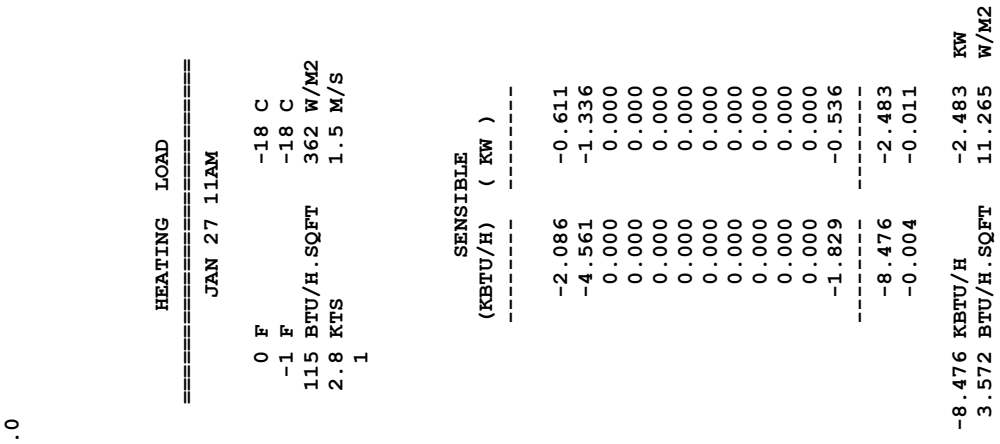

$\stackrel{\circ}{\circ}$

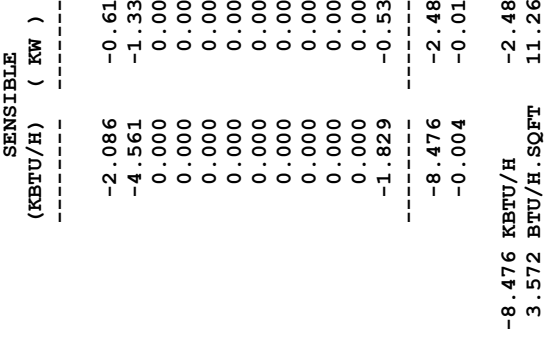
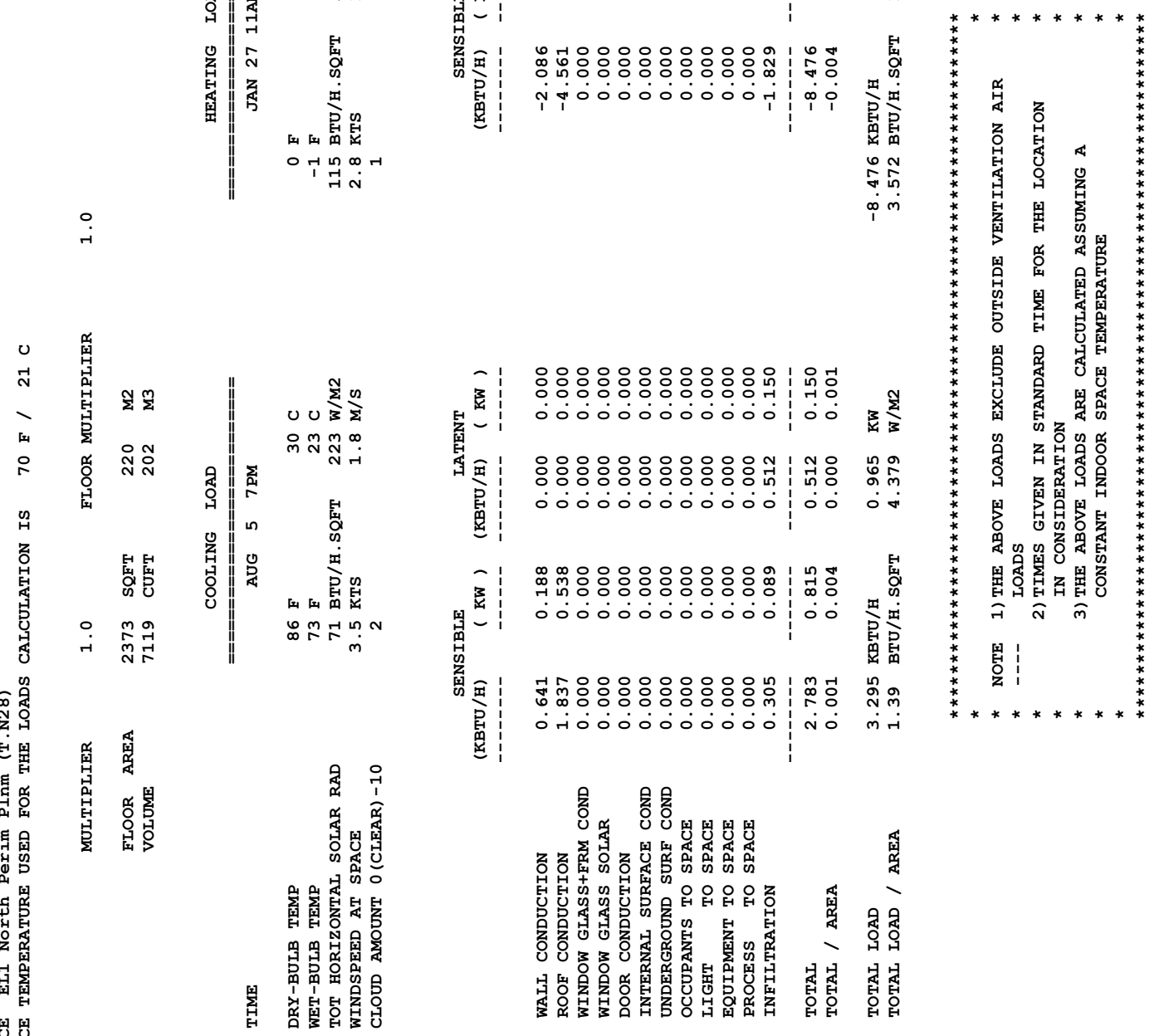


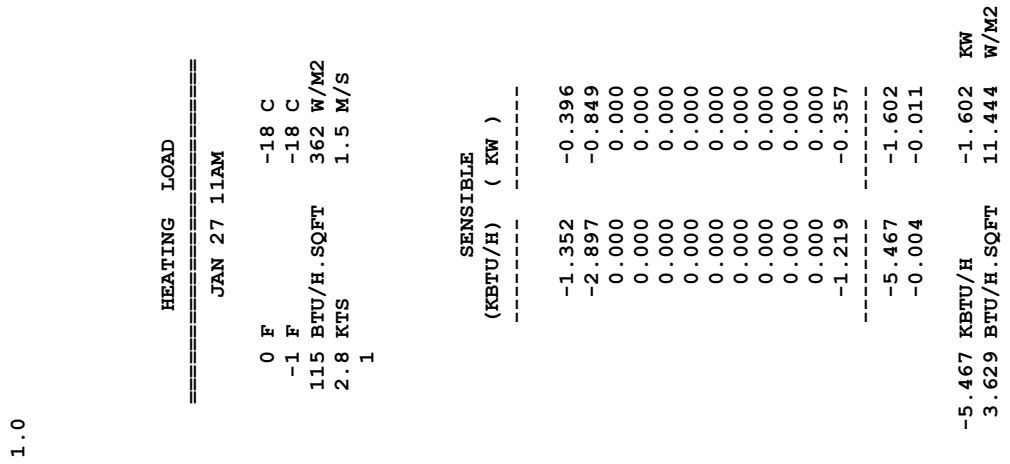

ํ.
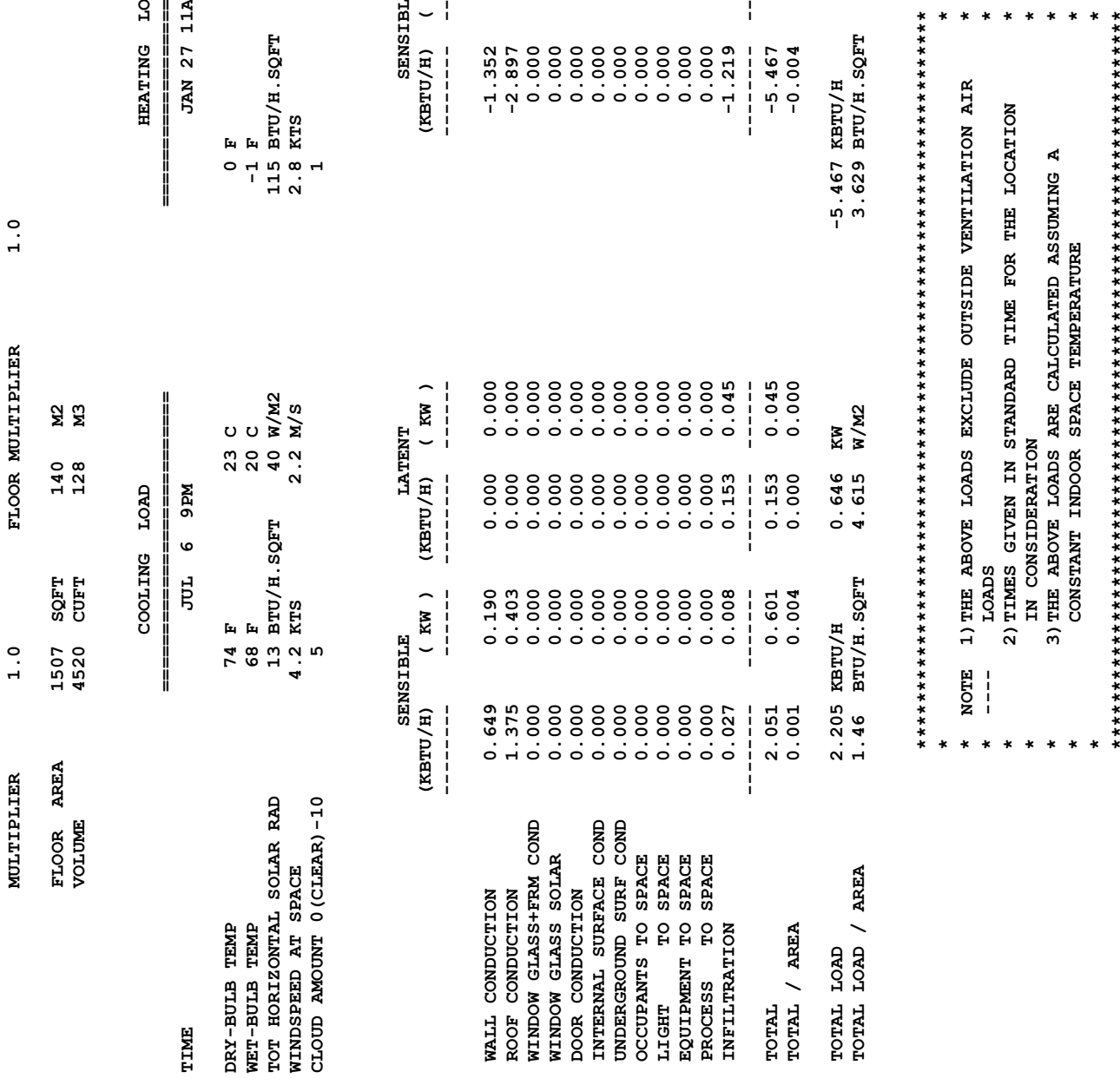
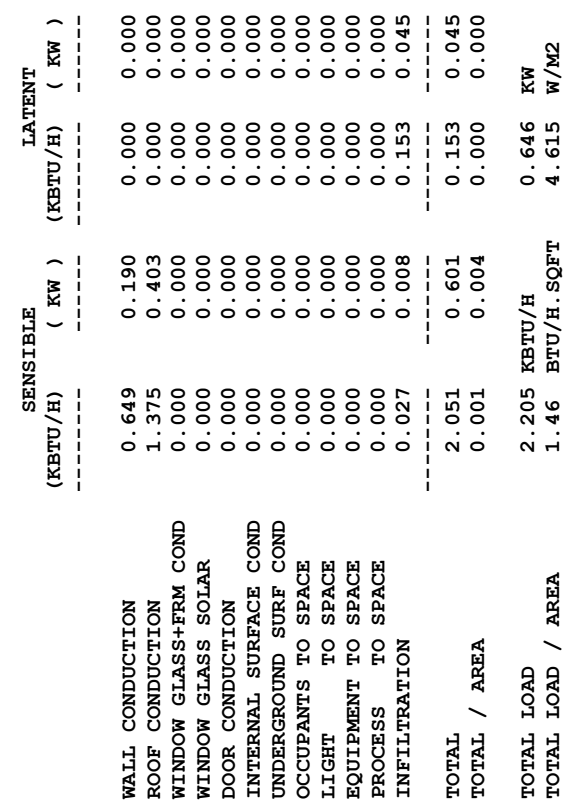


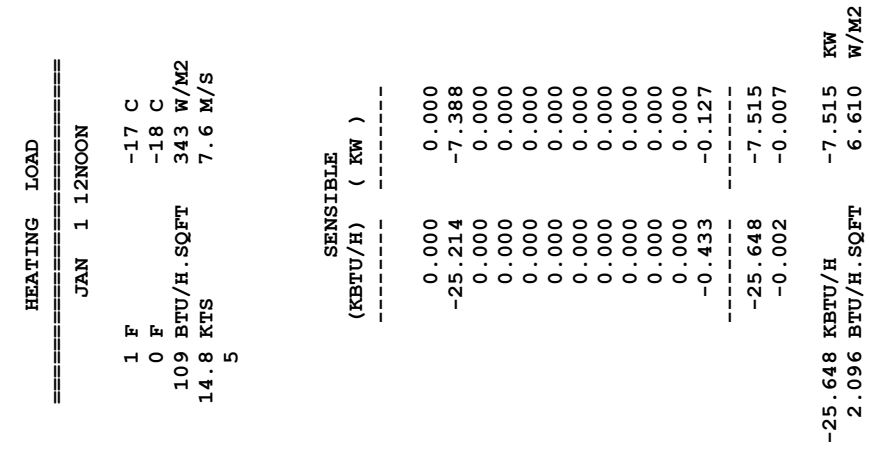

ํ.

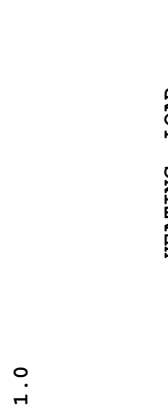

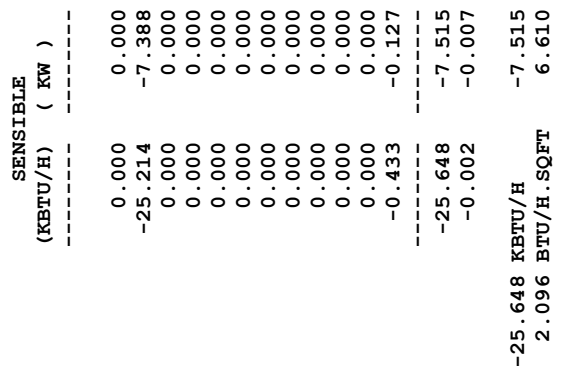
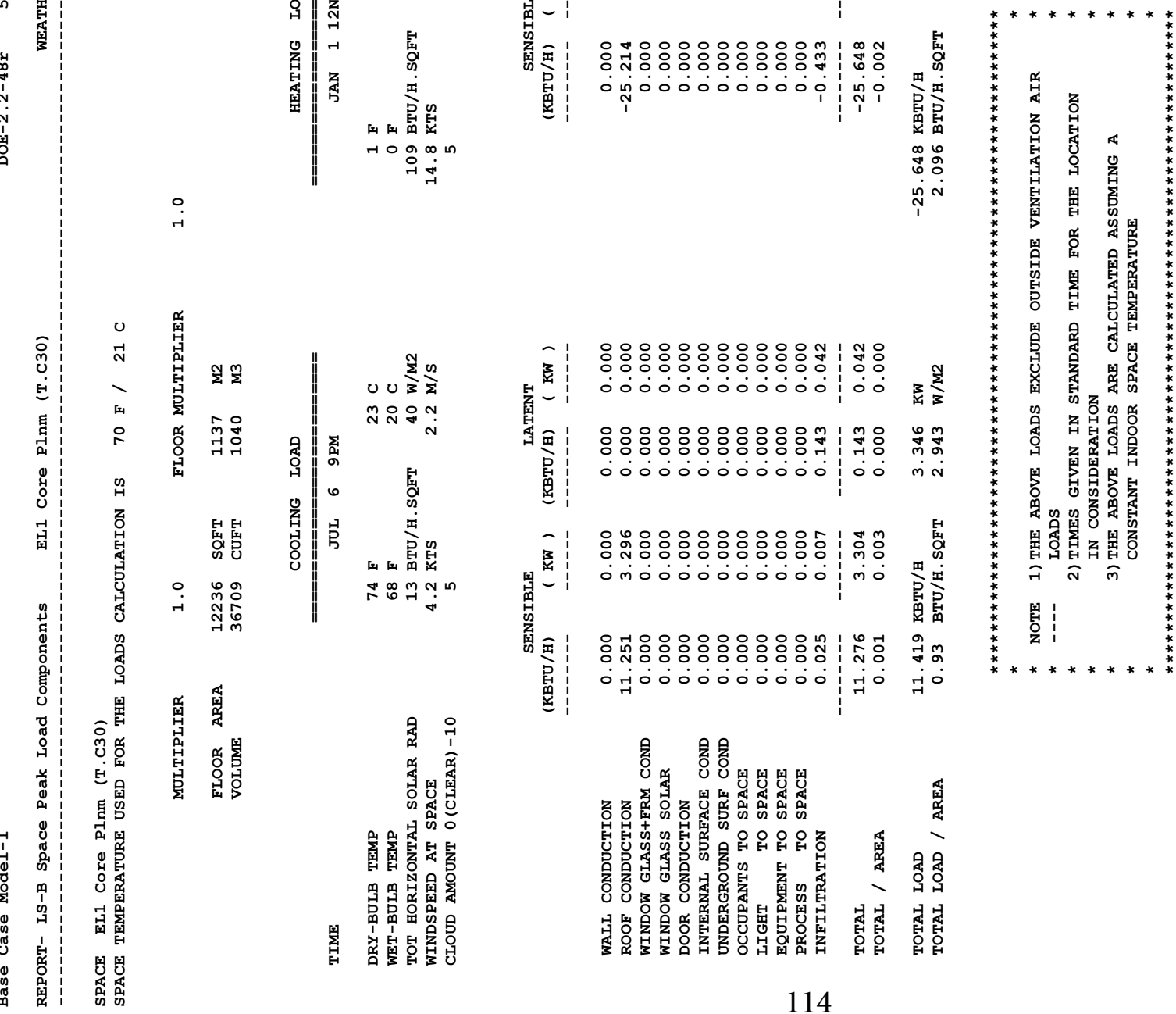

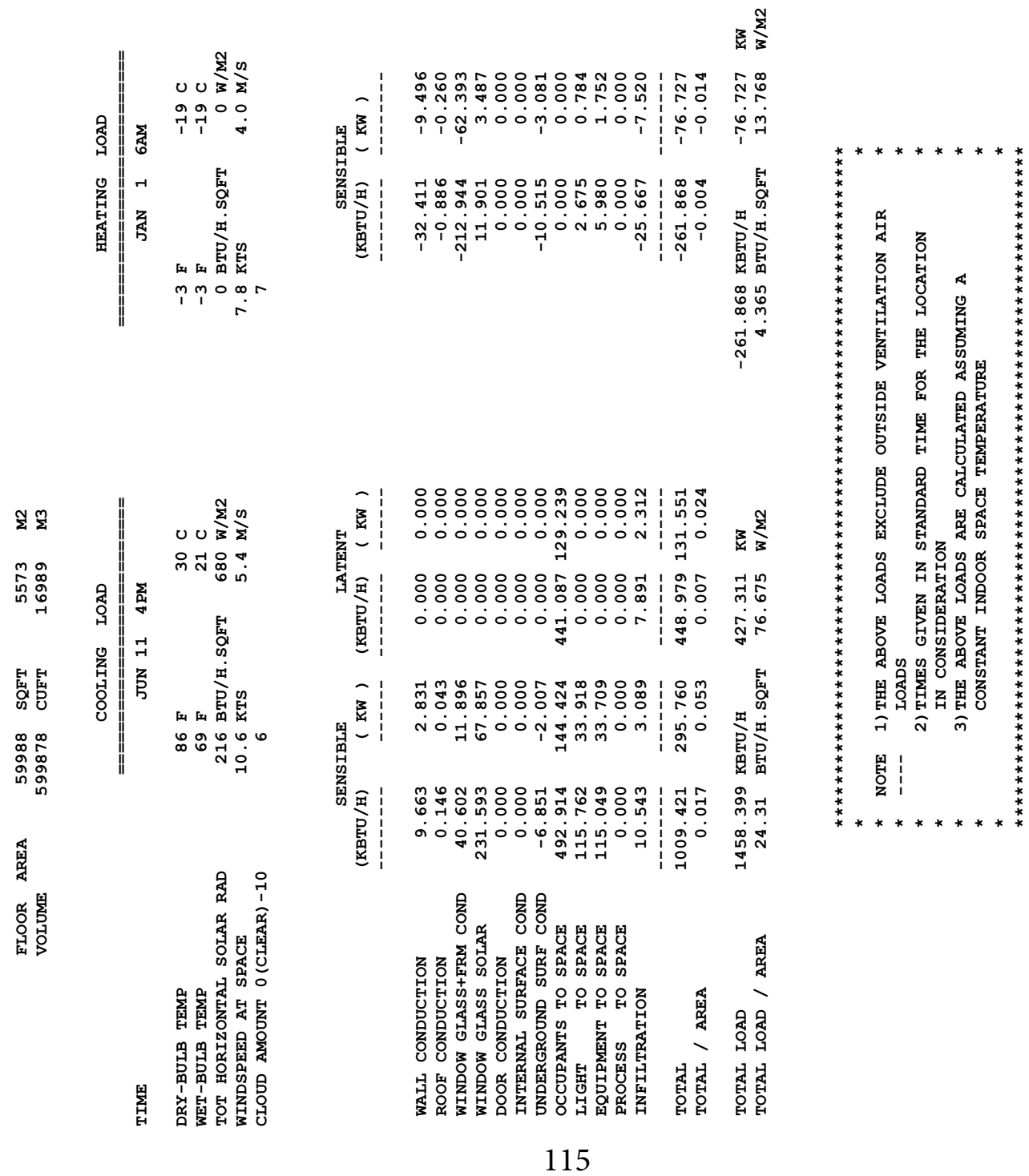


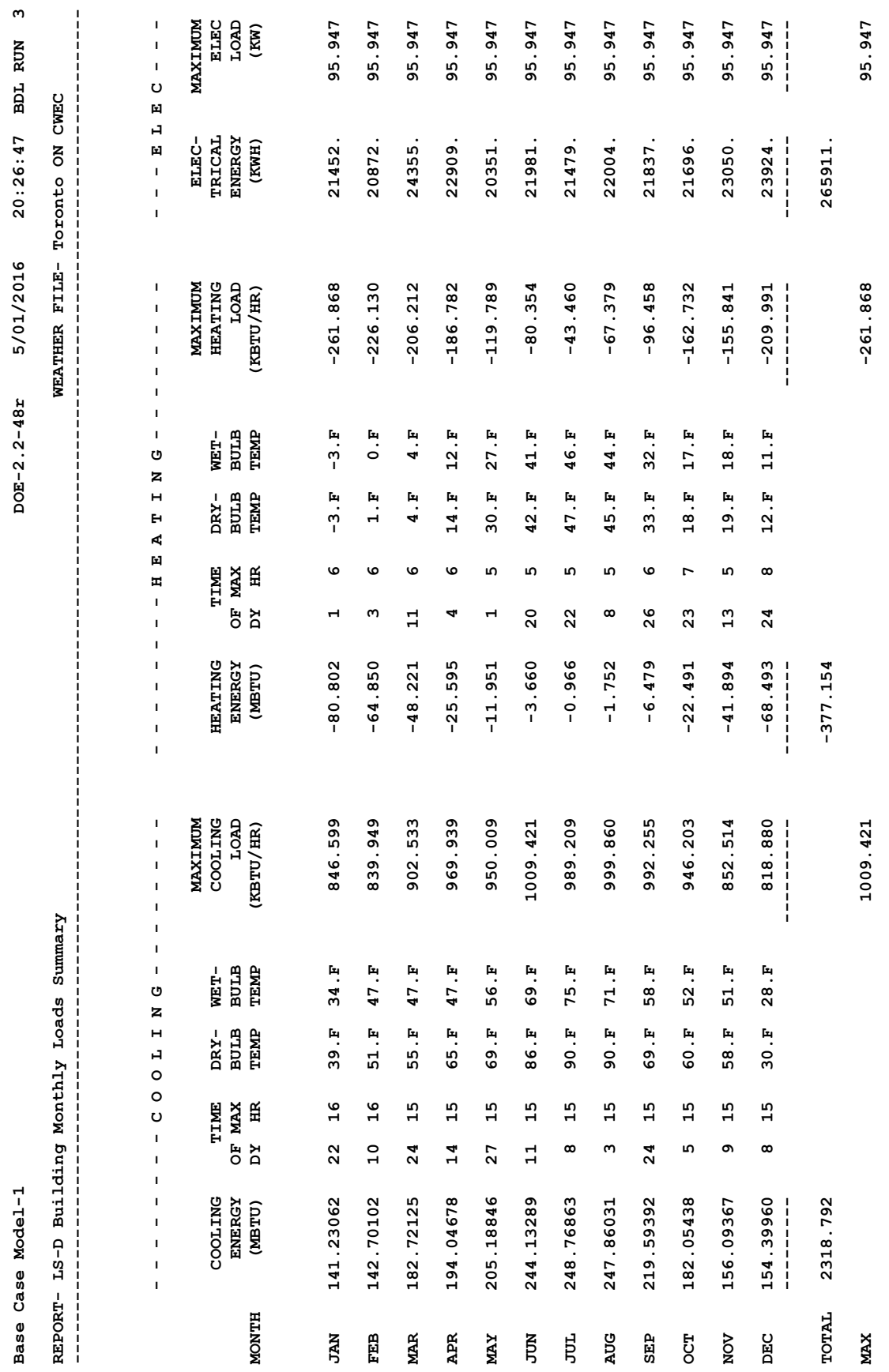




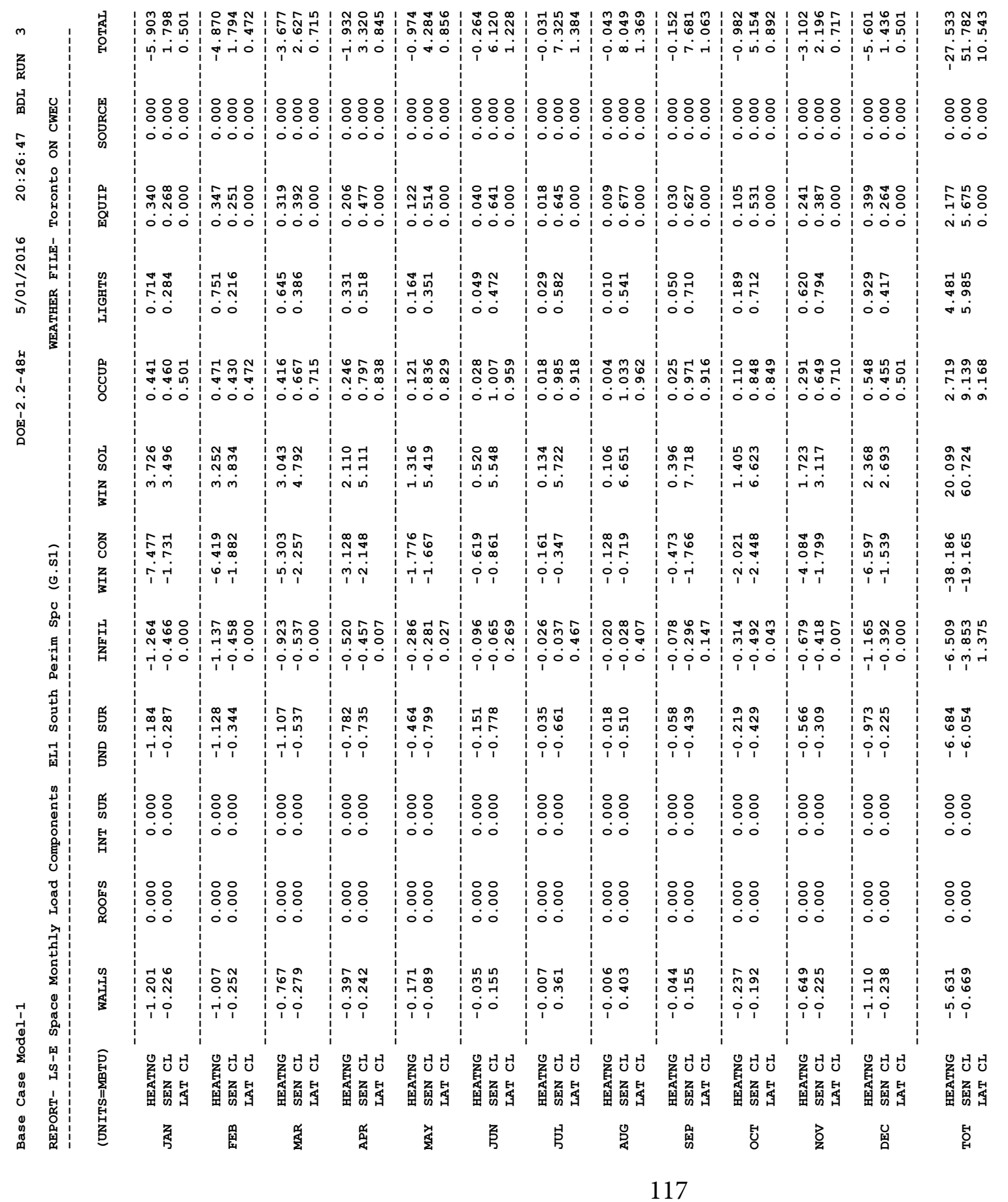




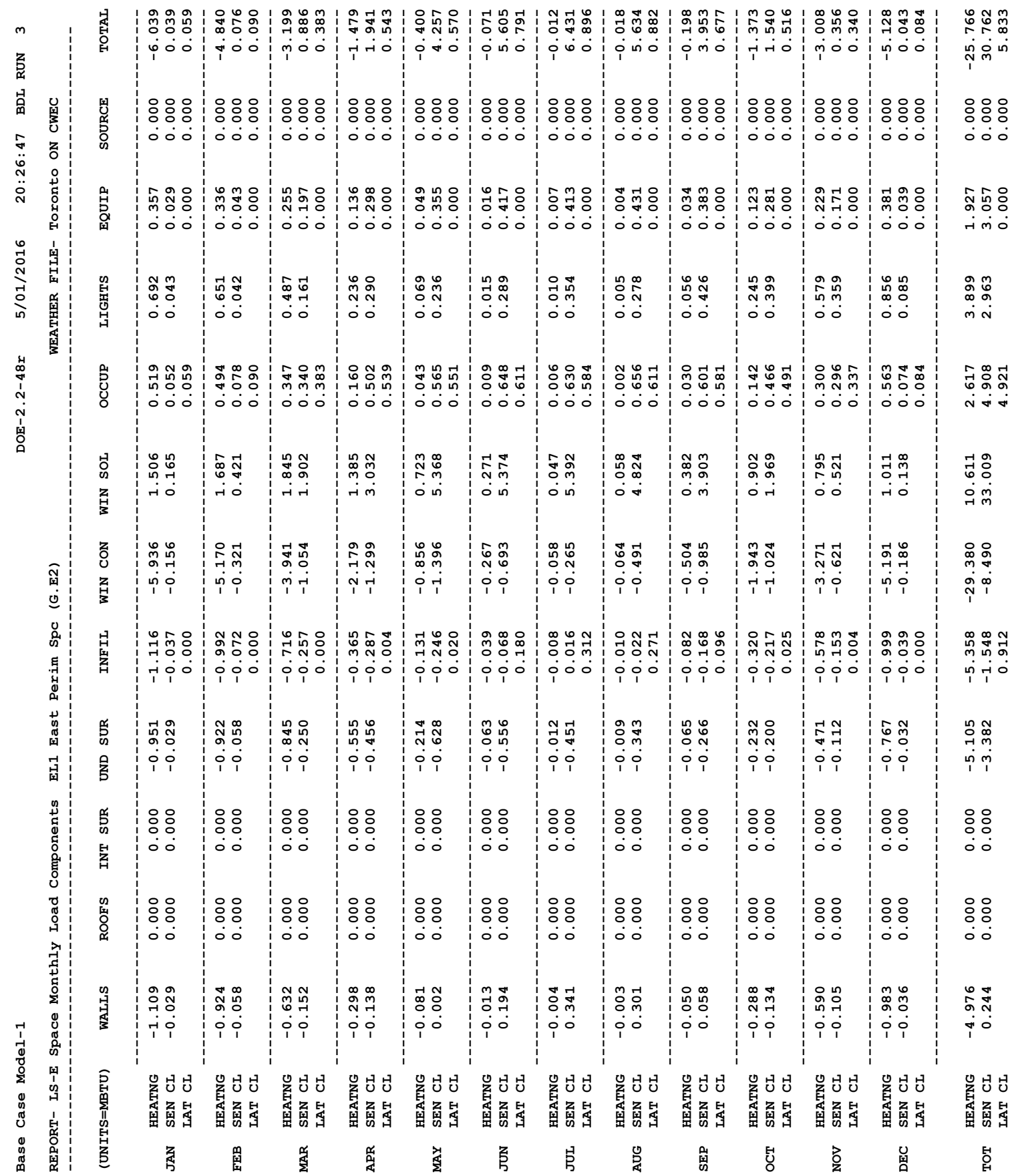




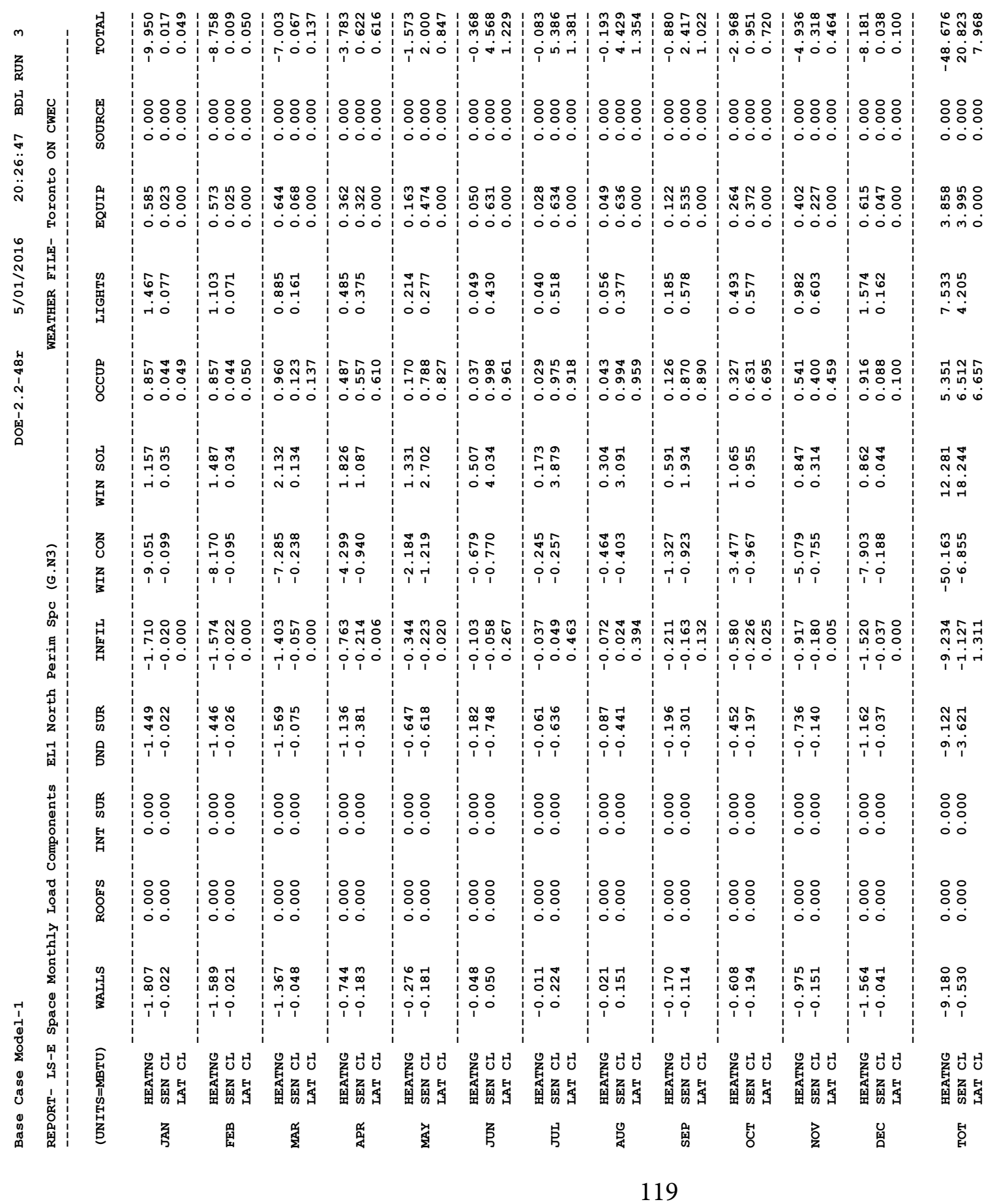




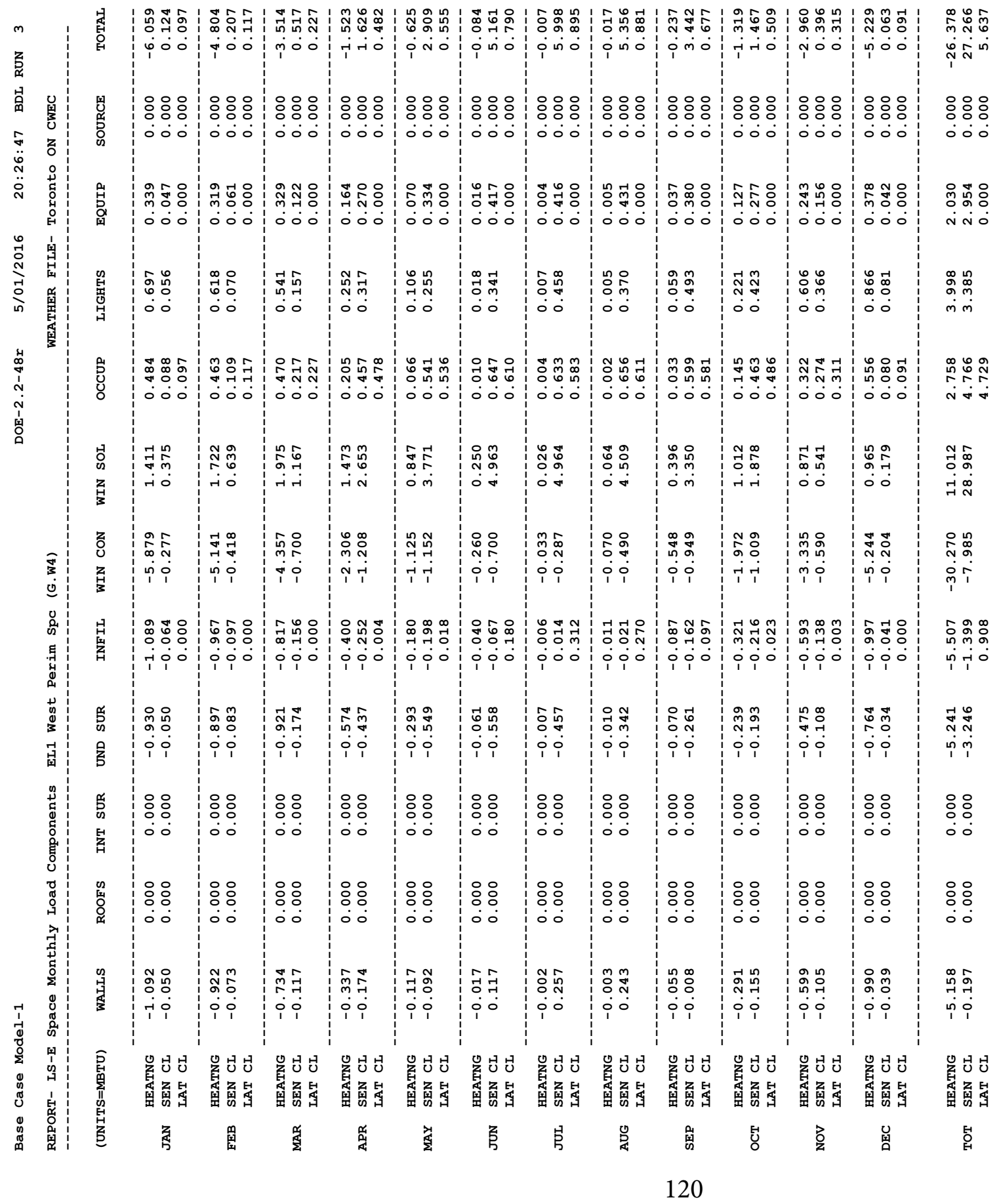




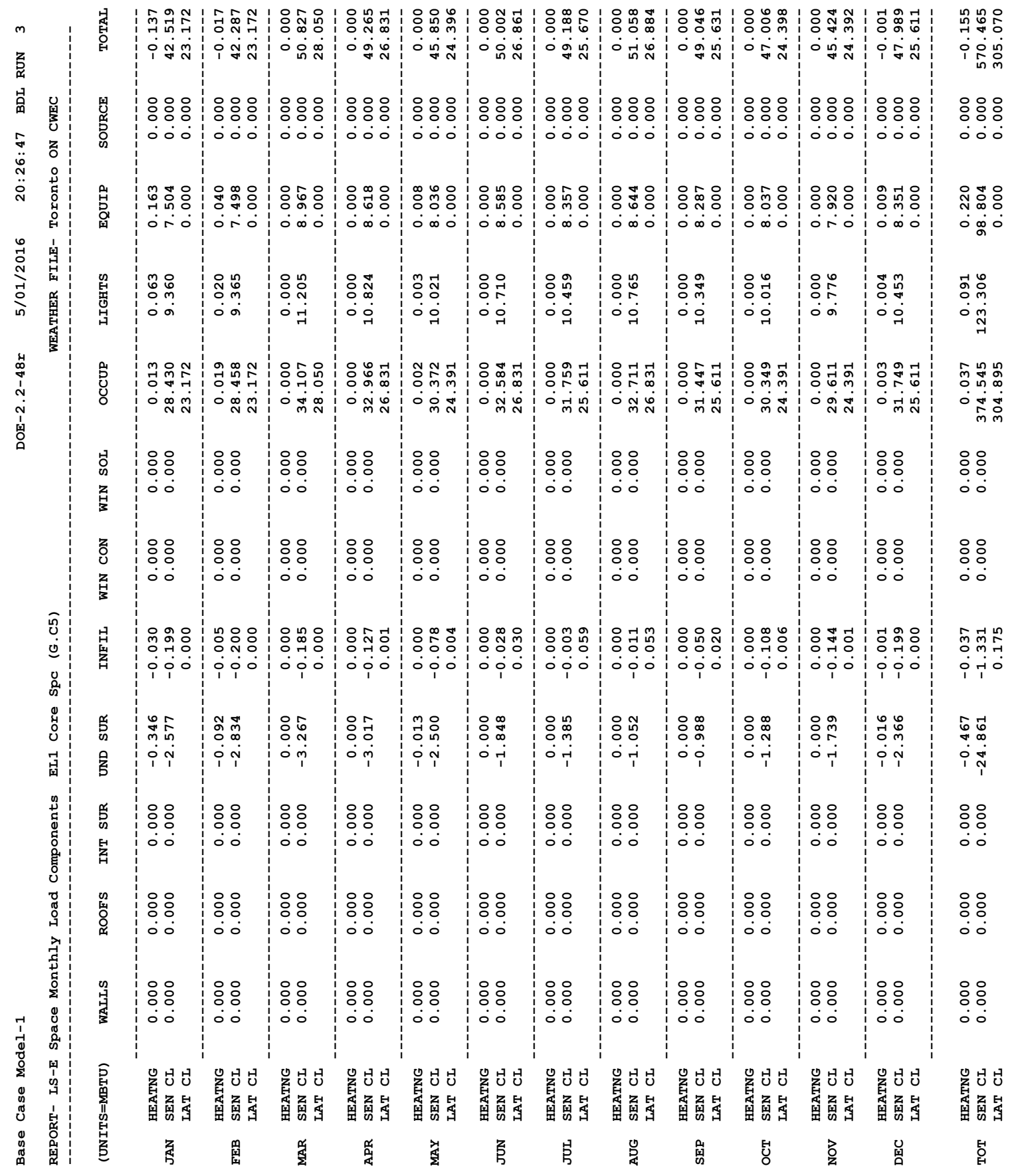




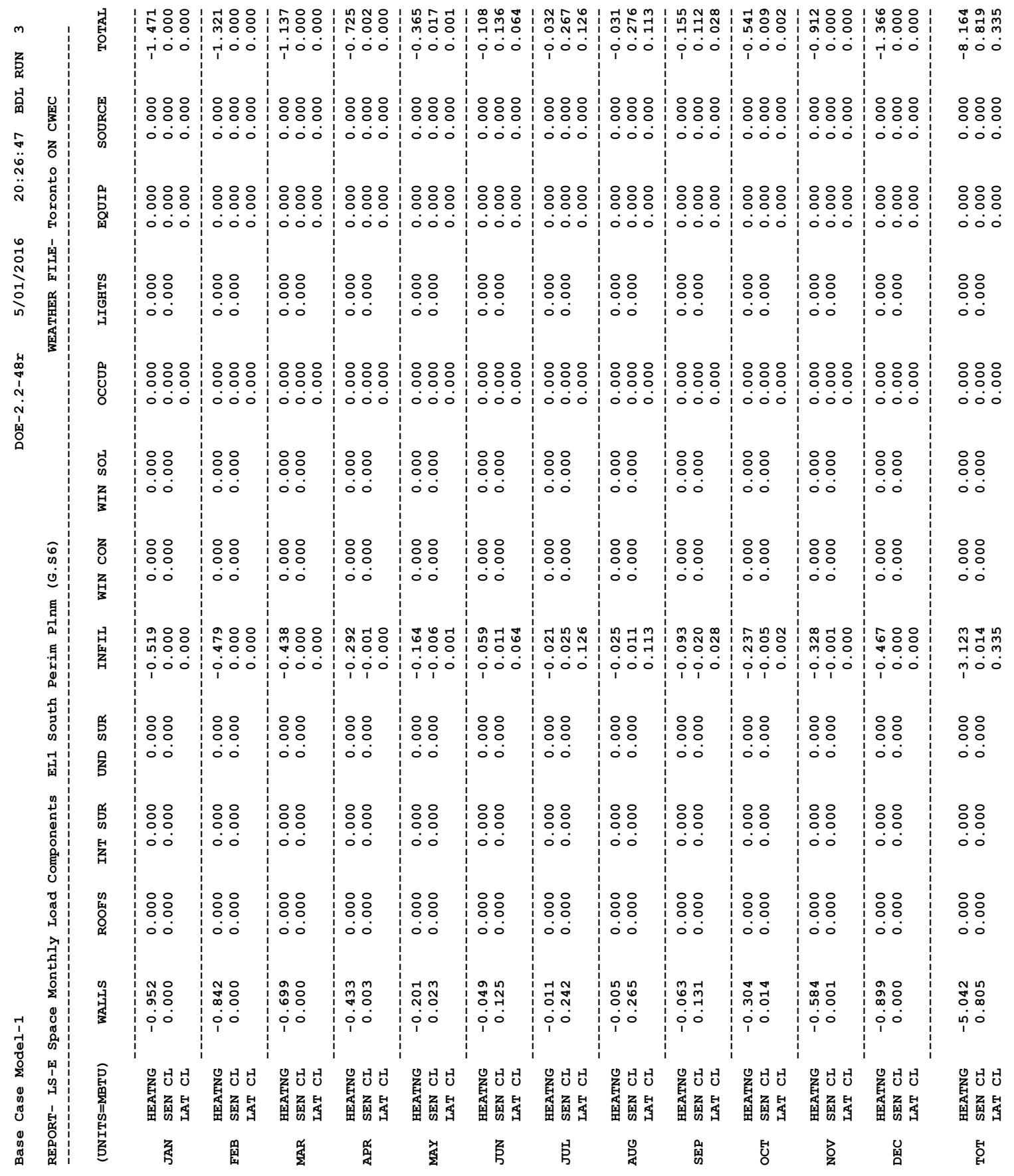




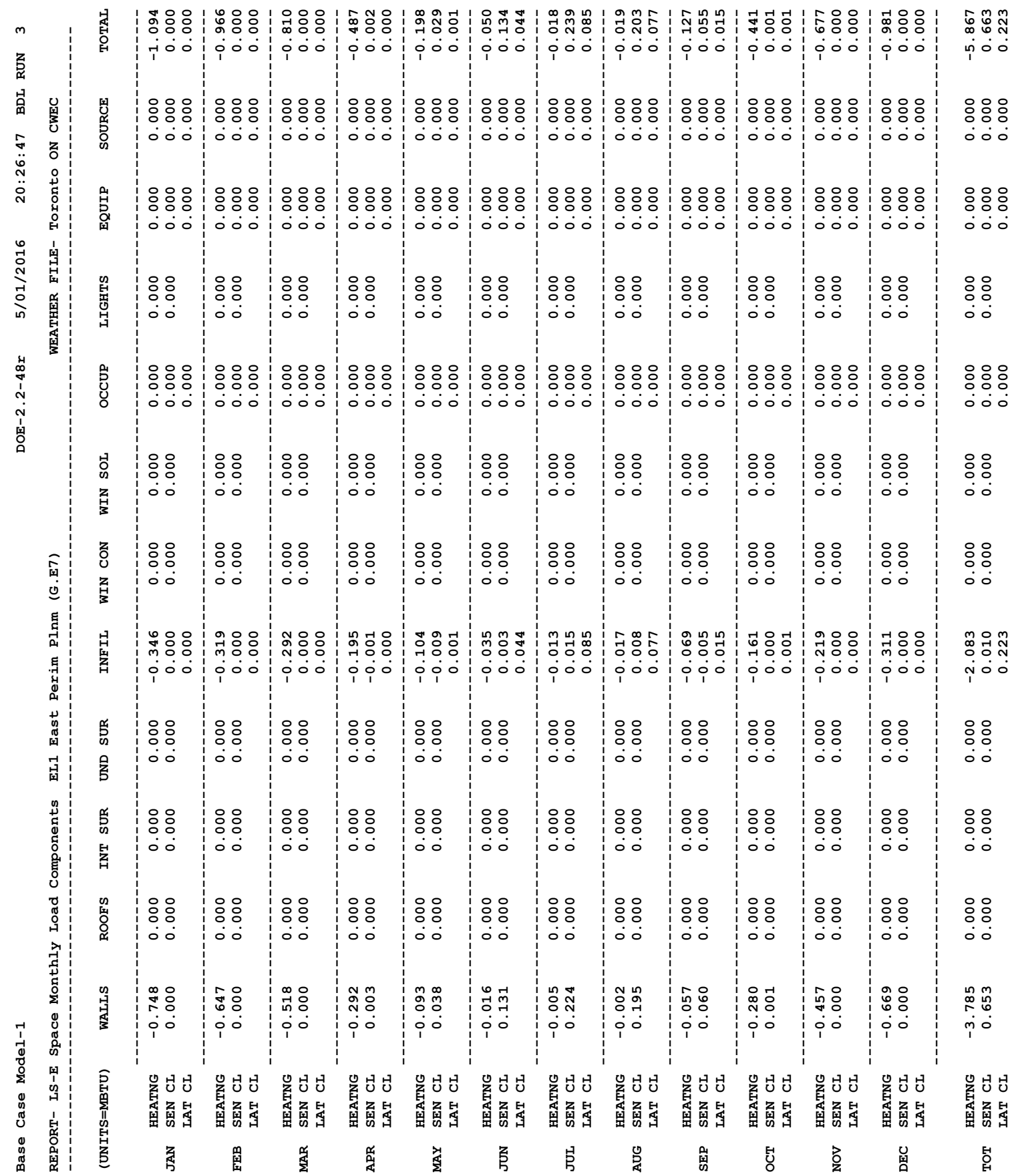




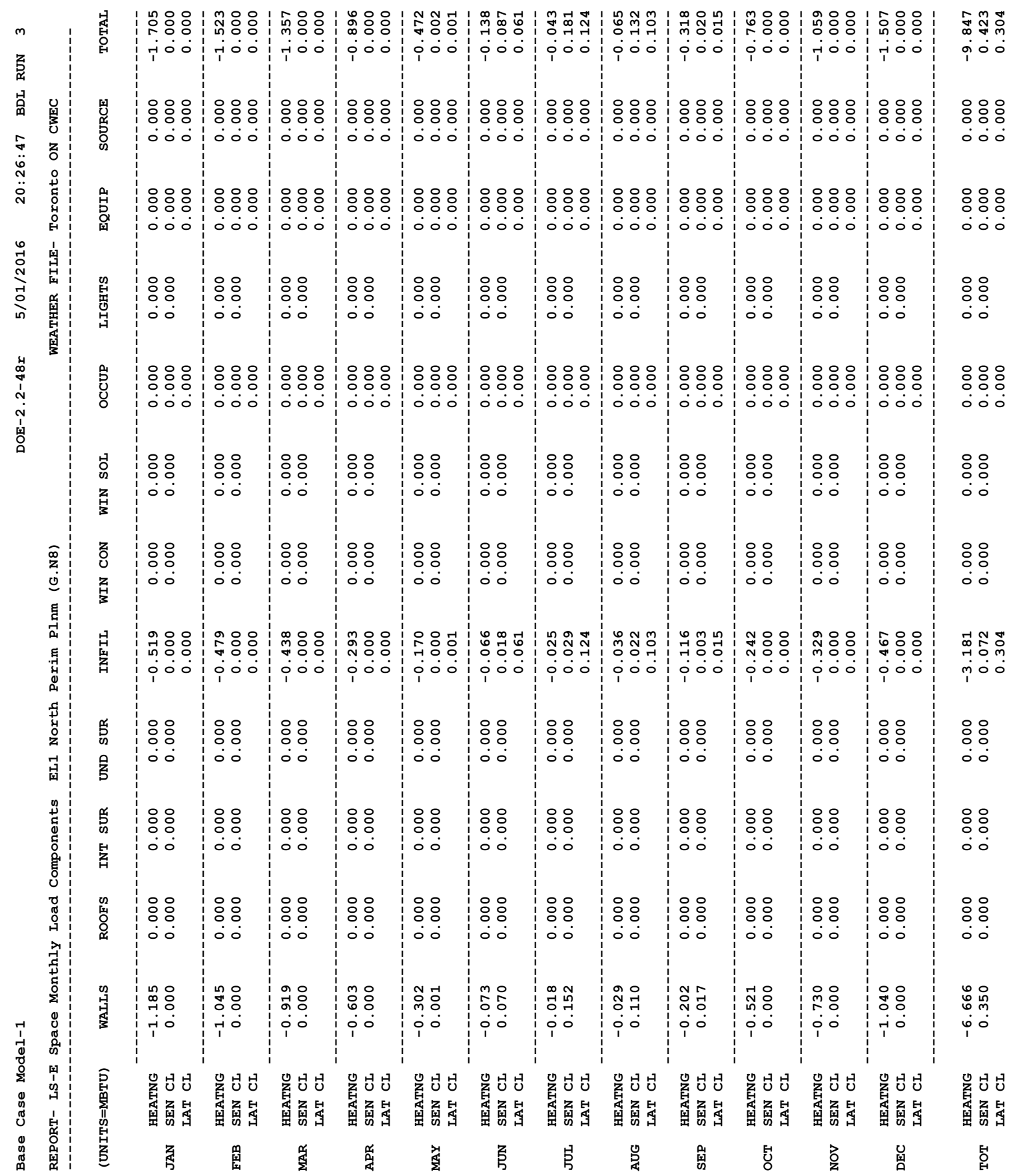




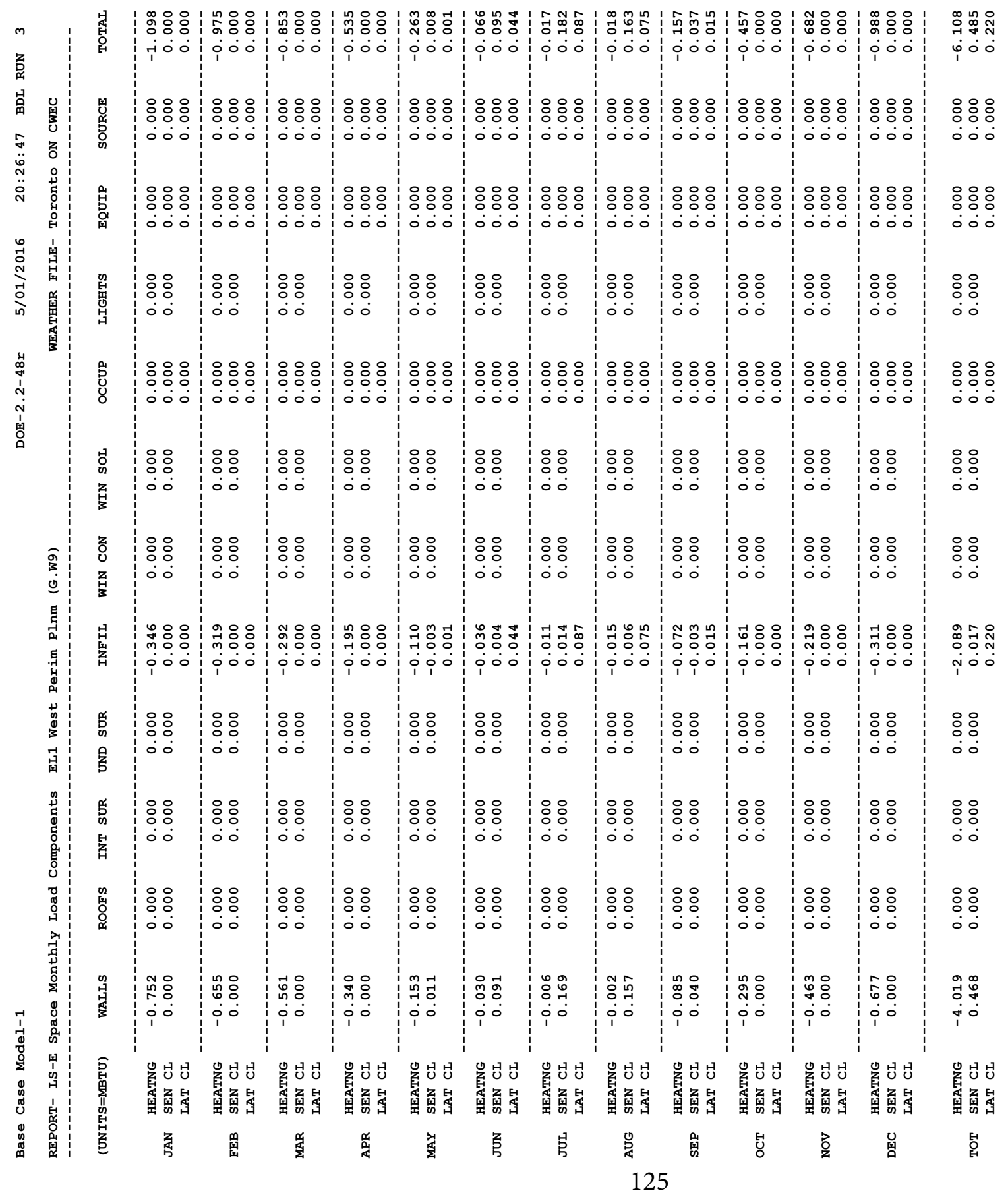




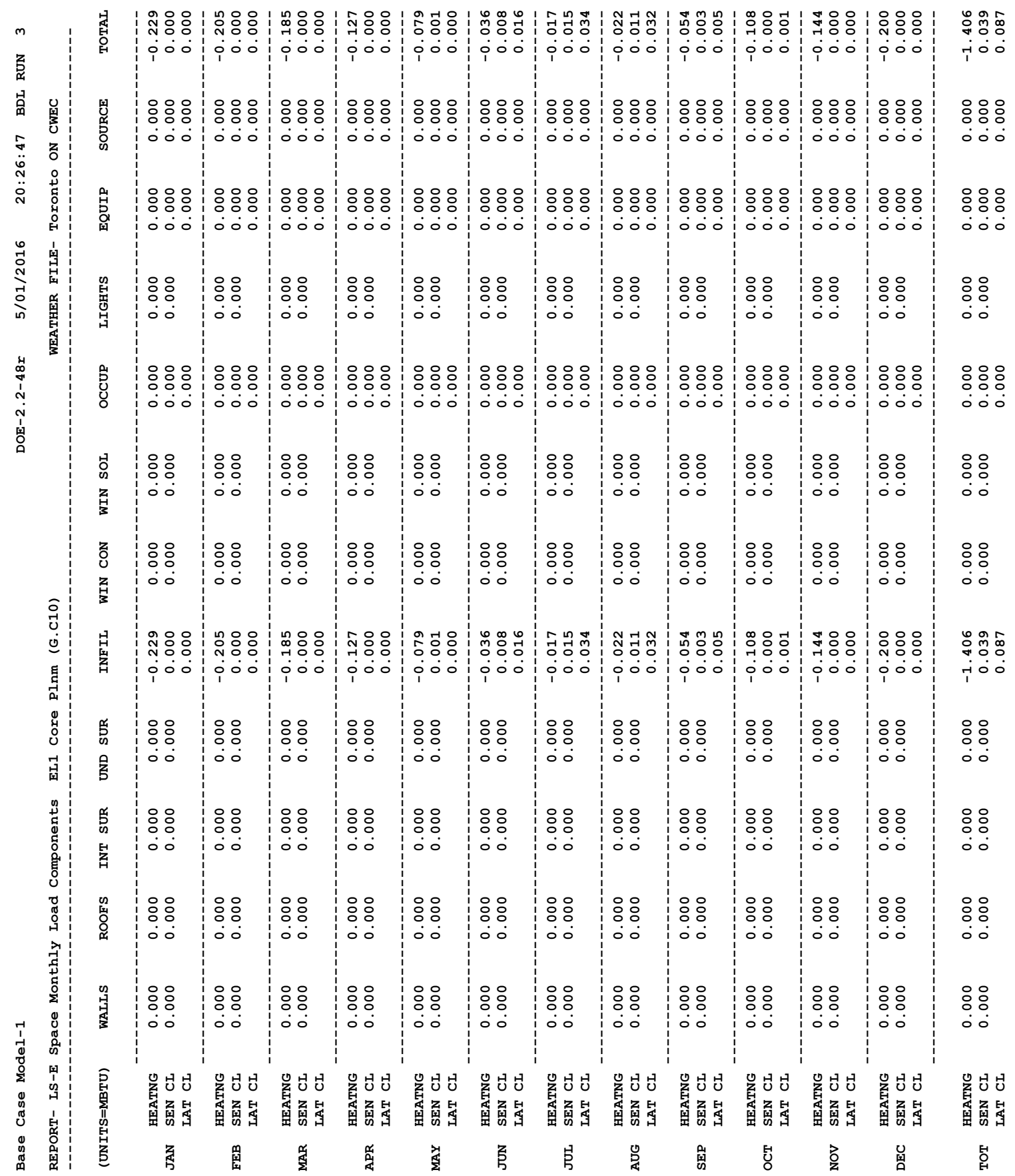




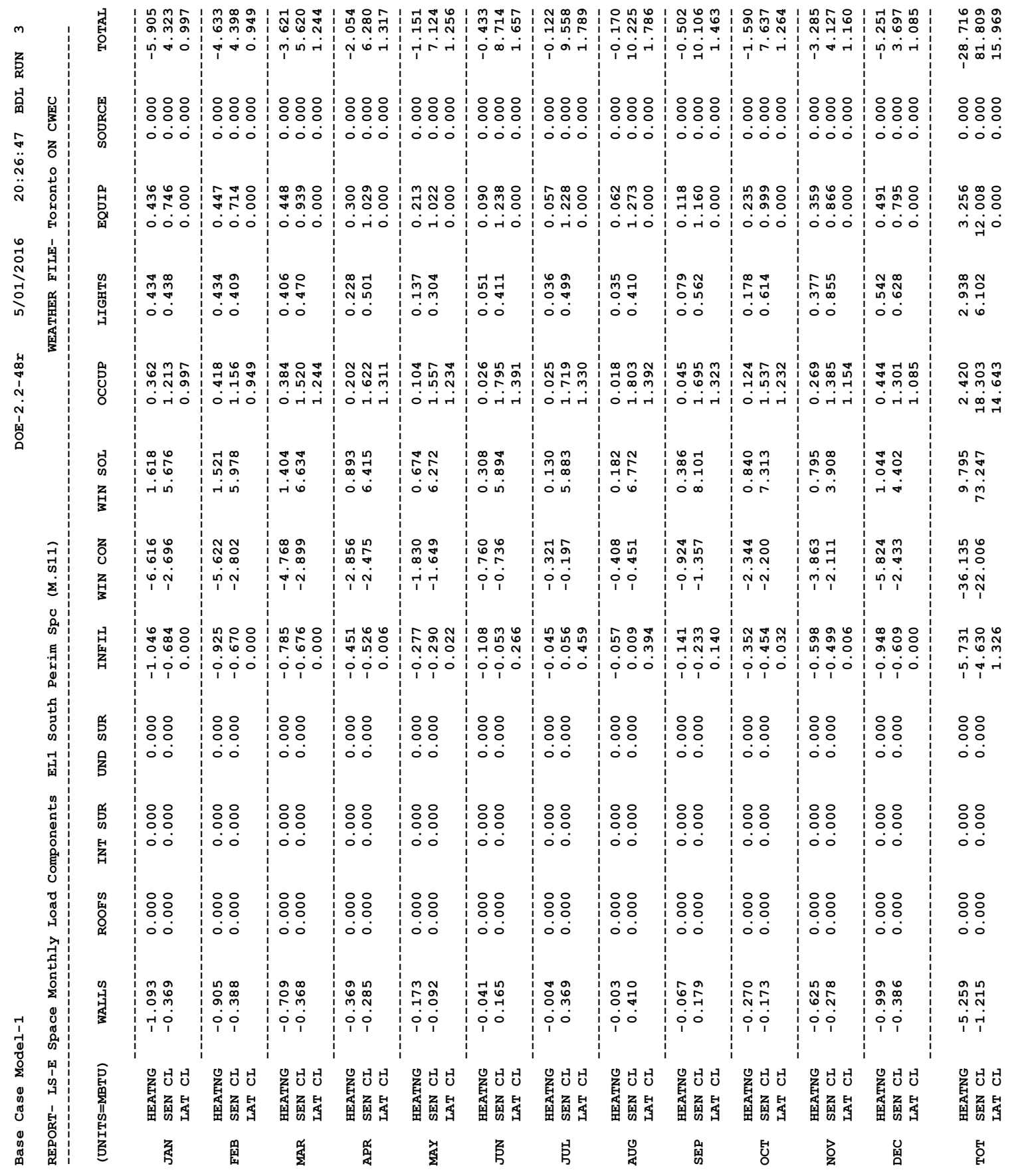




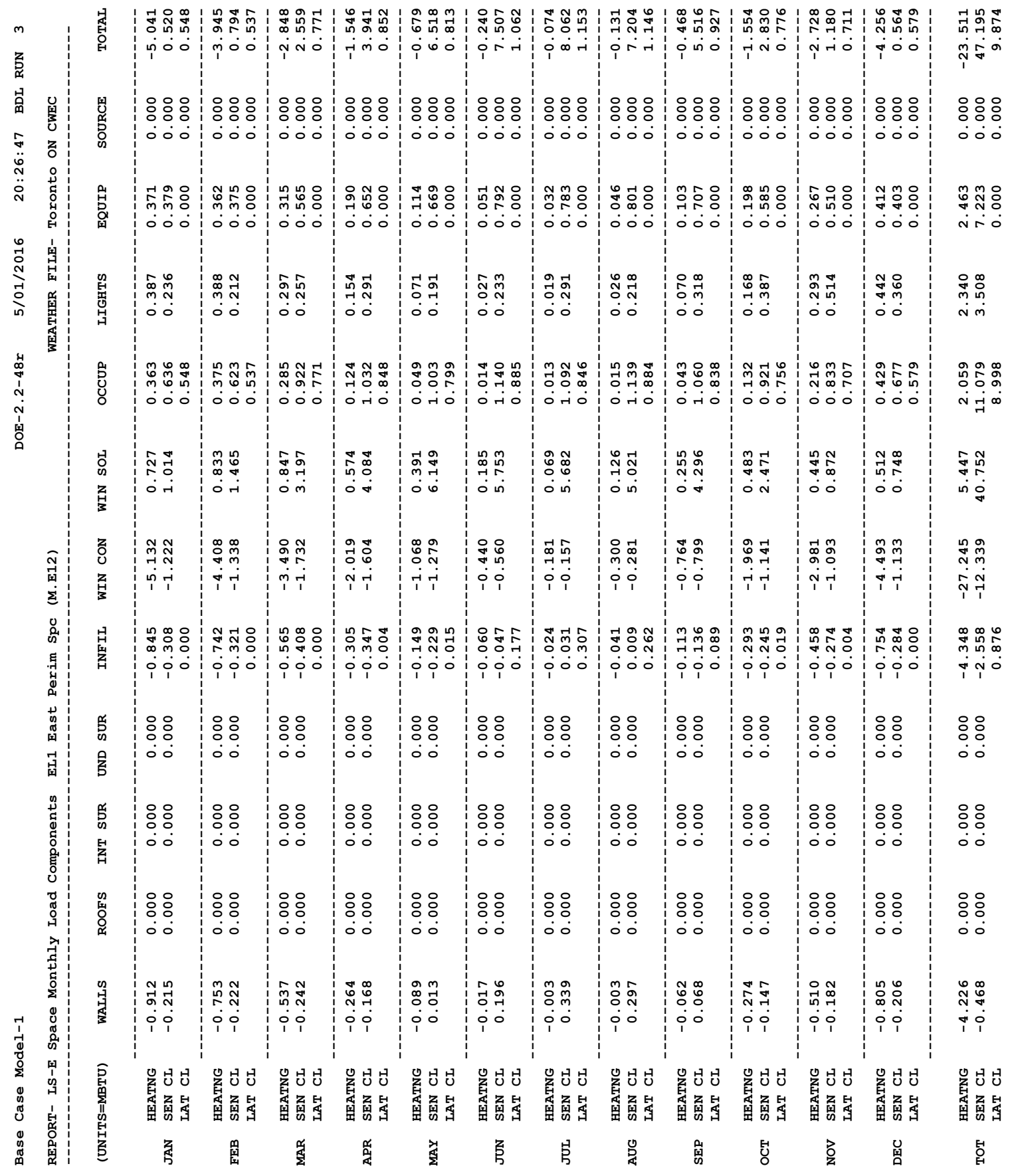




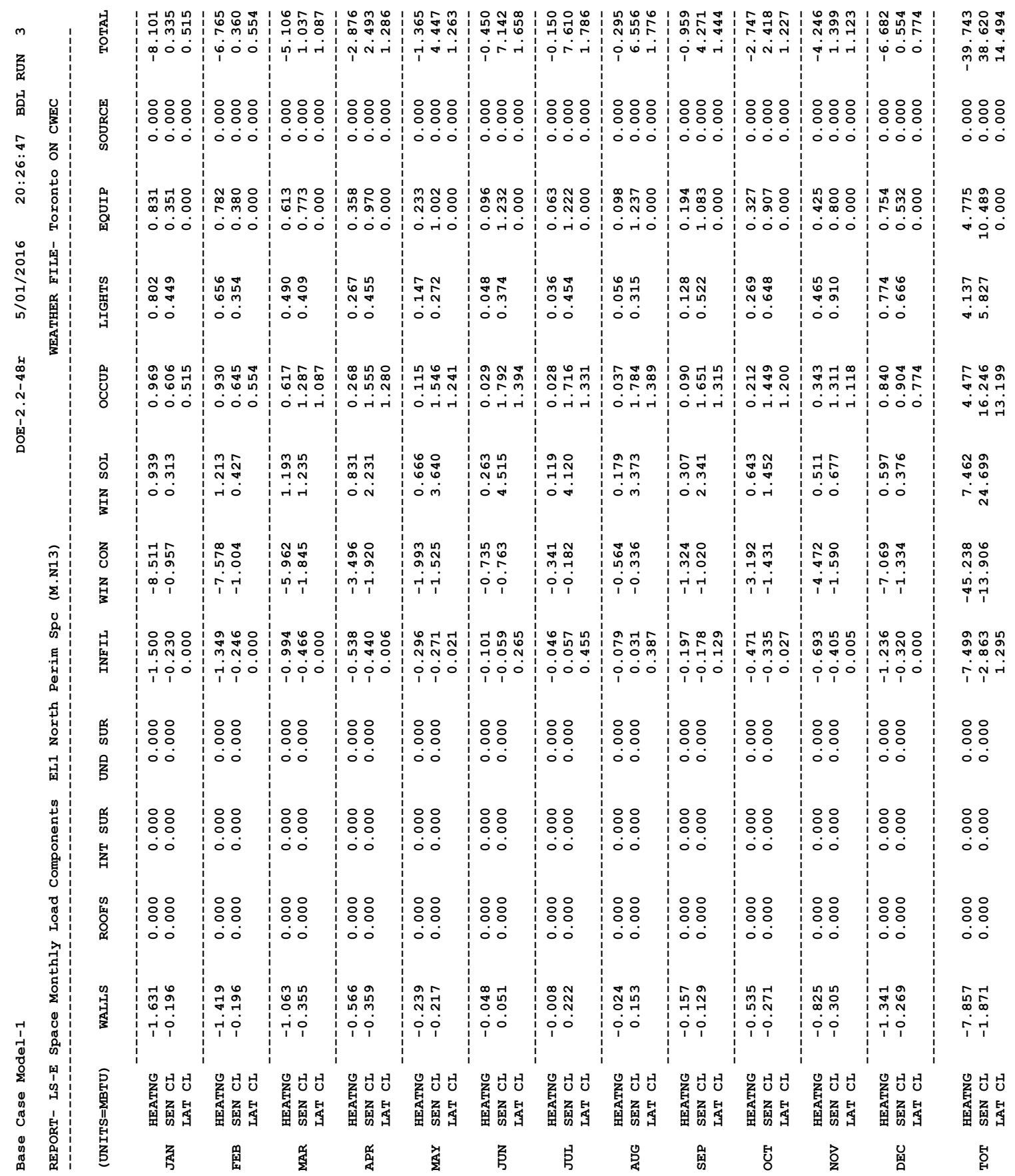




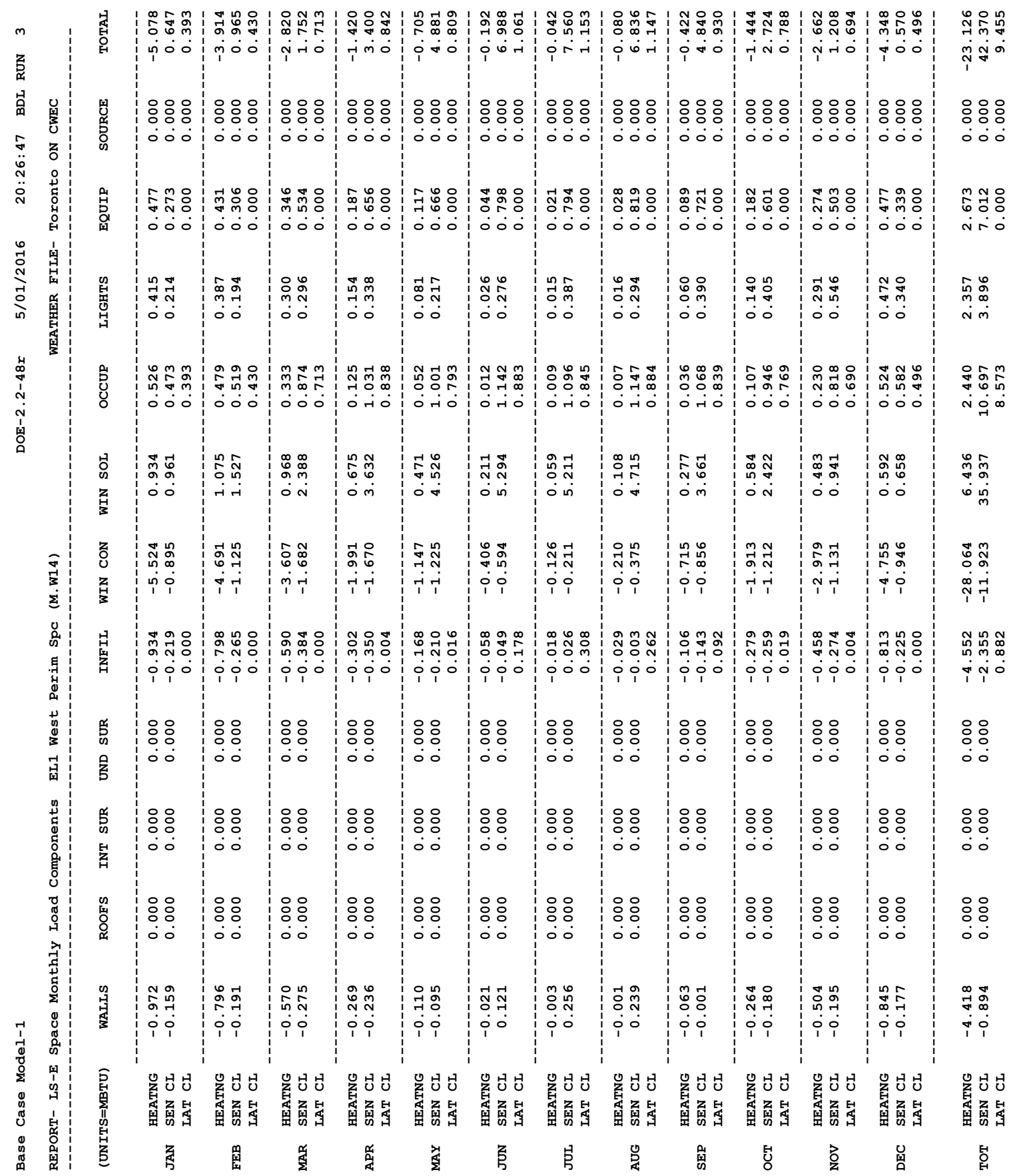




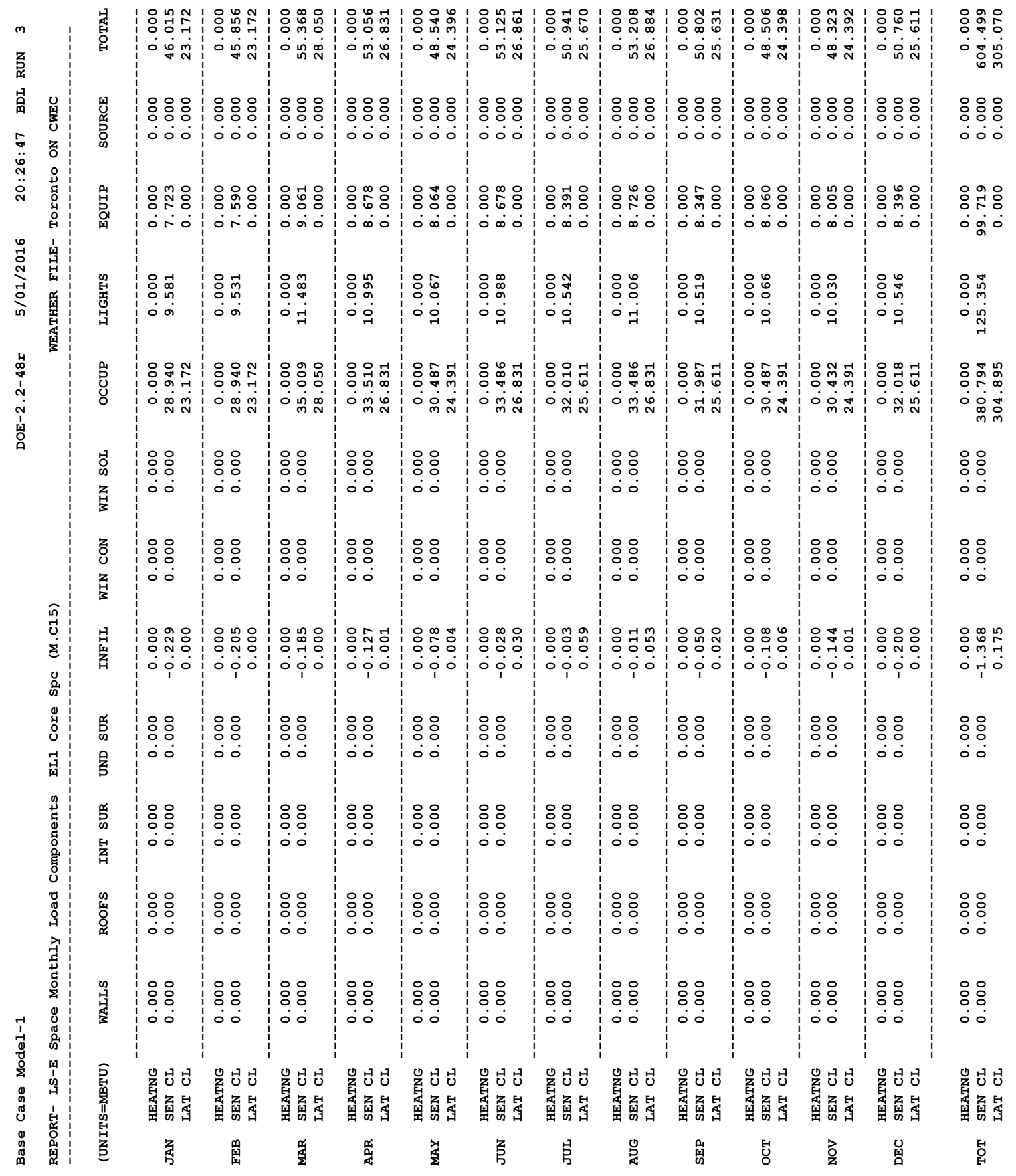




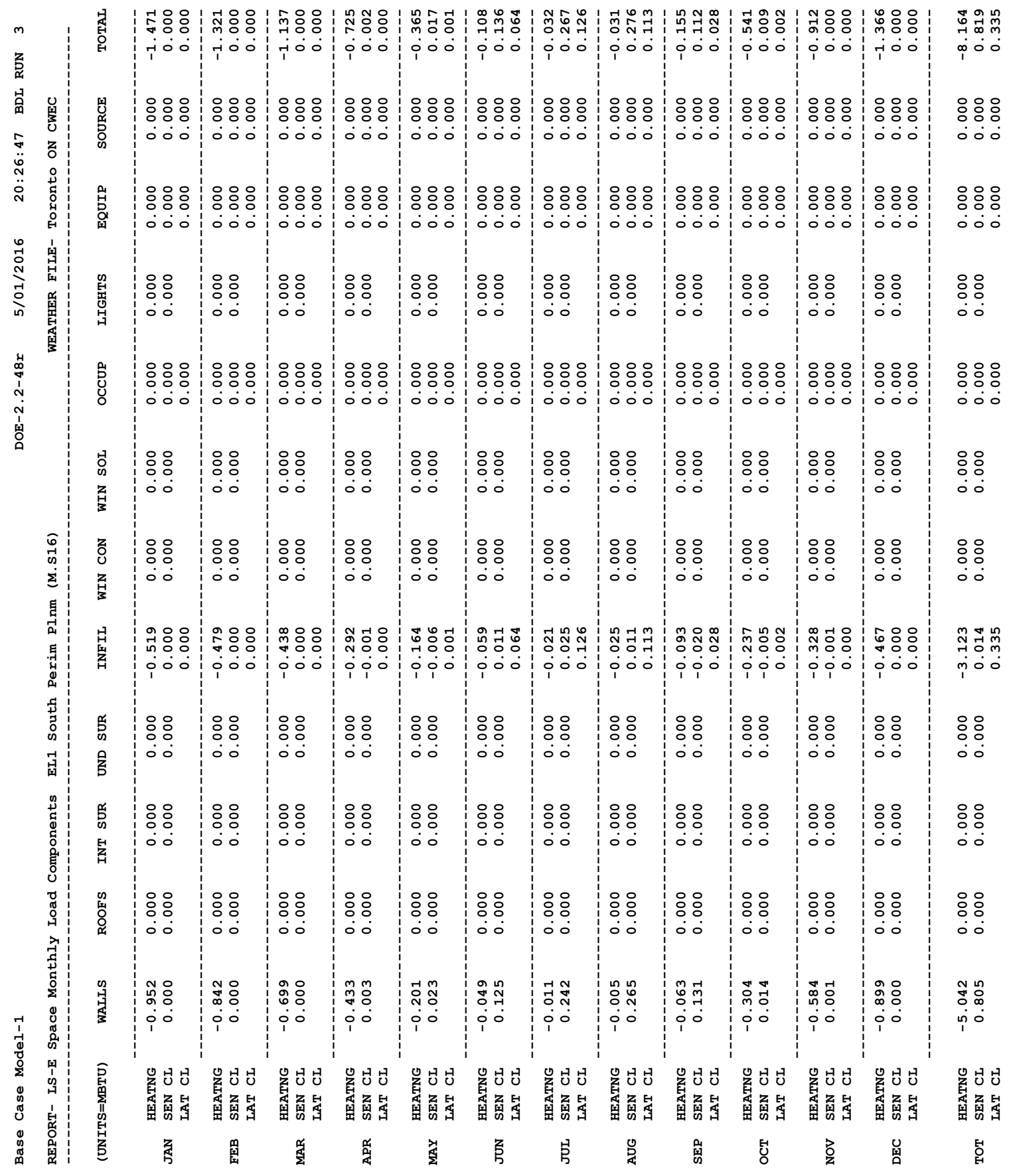




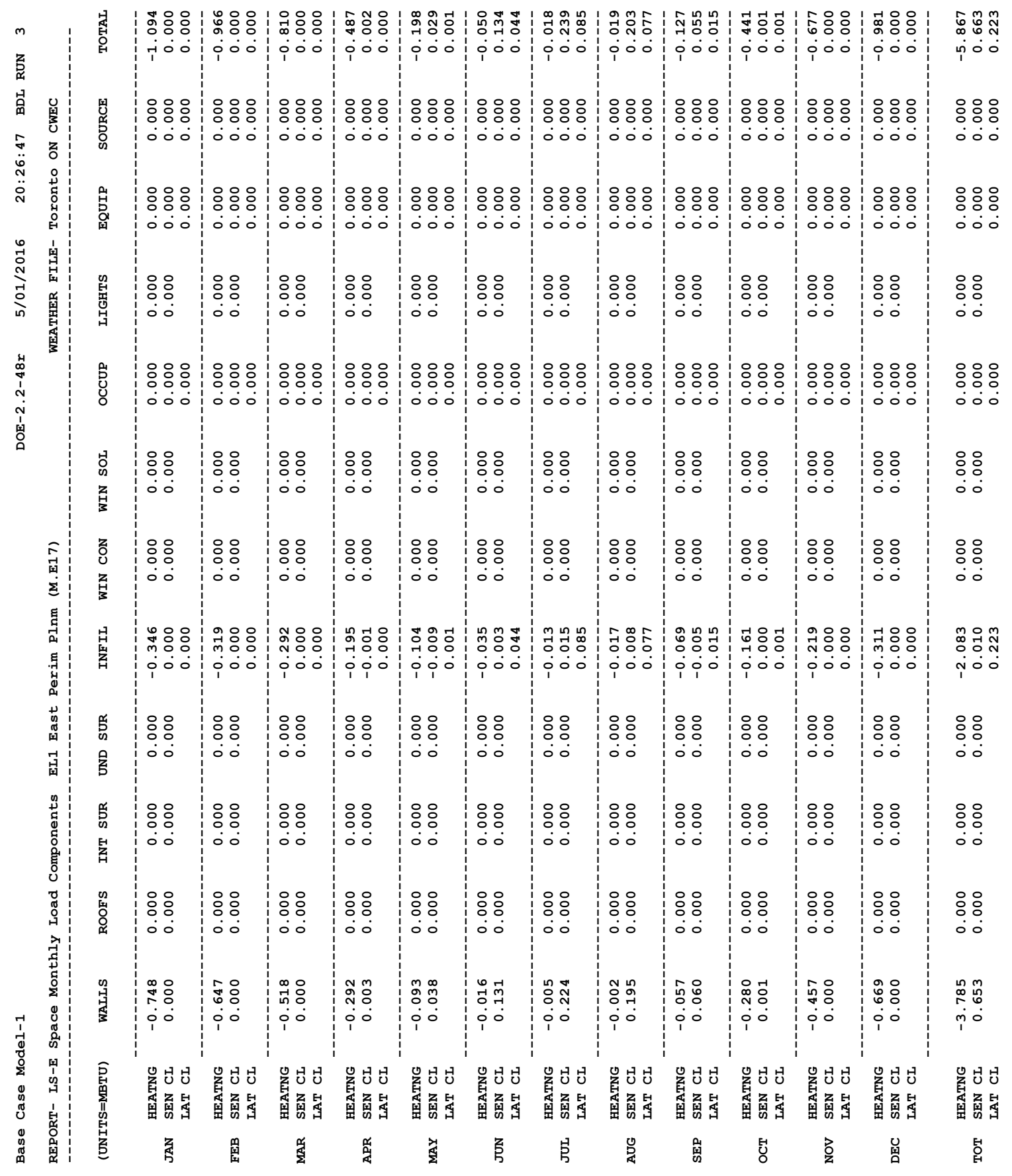




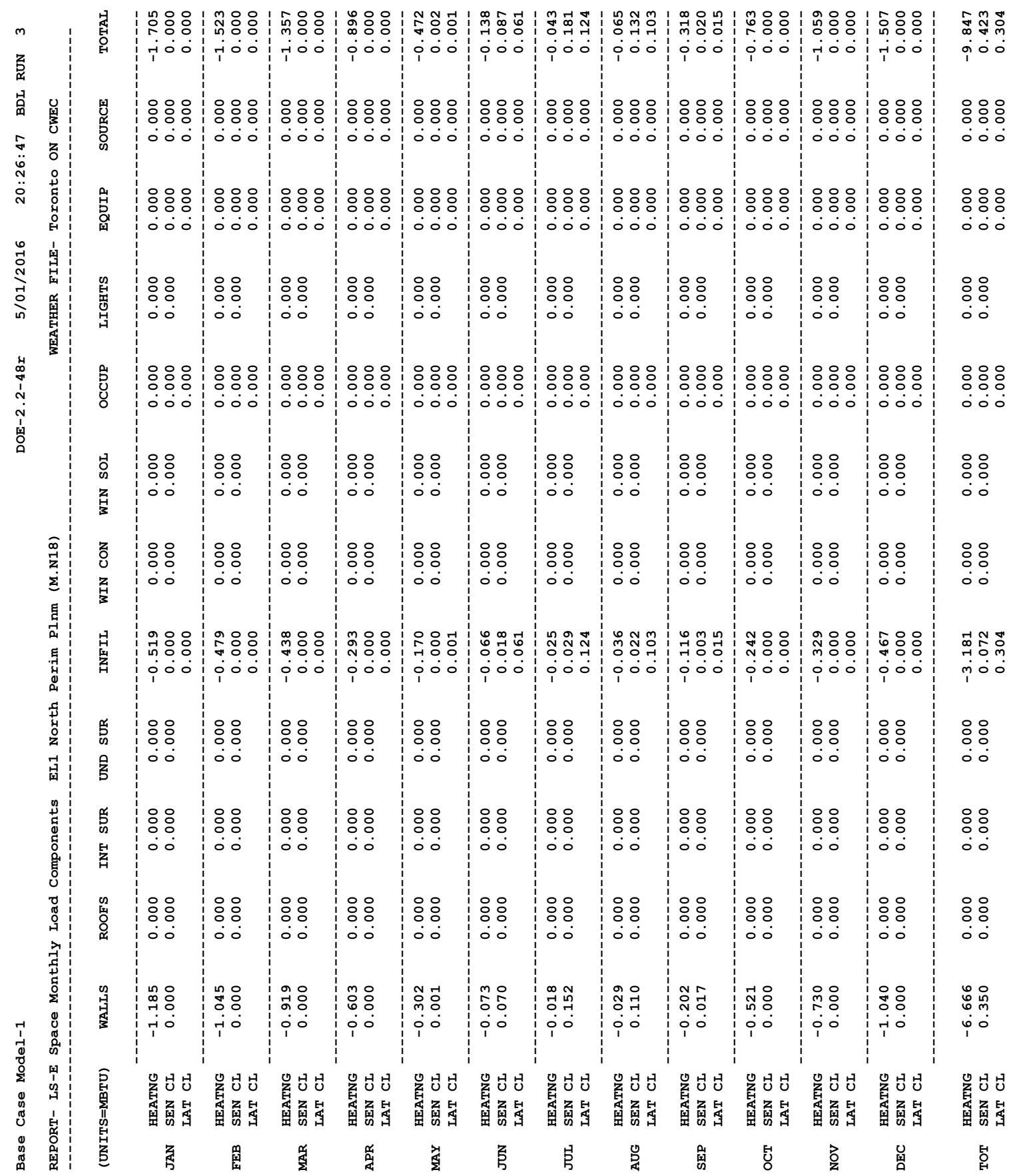




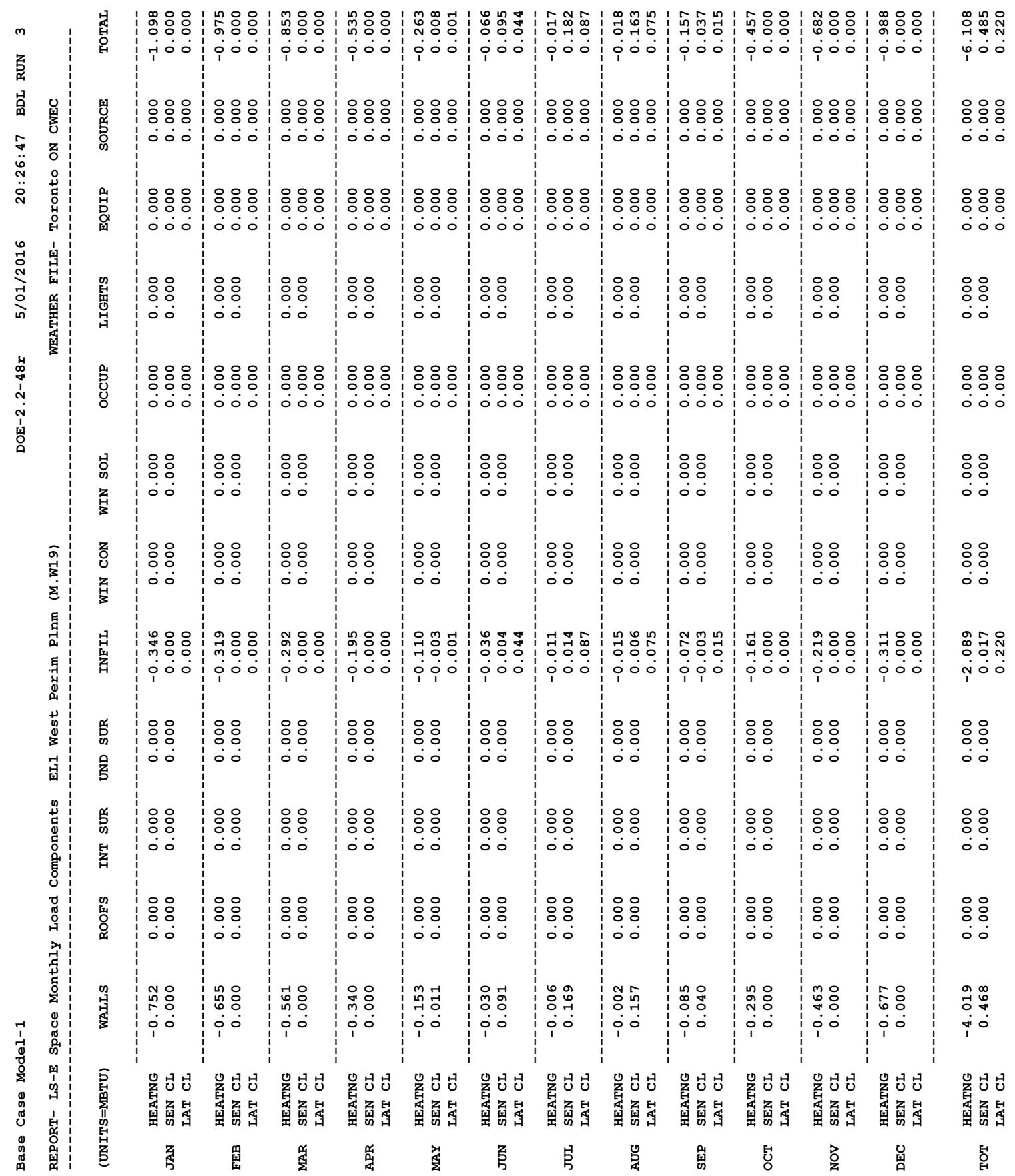




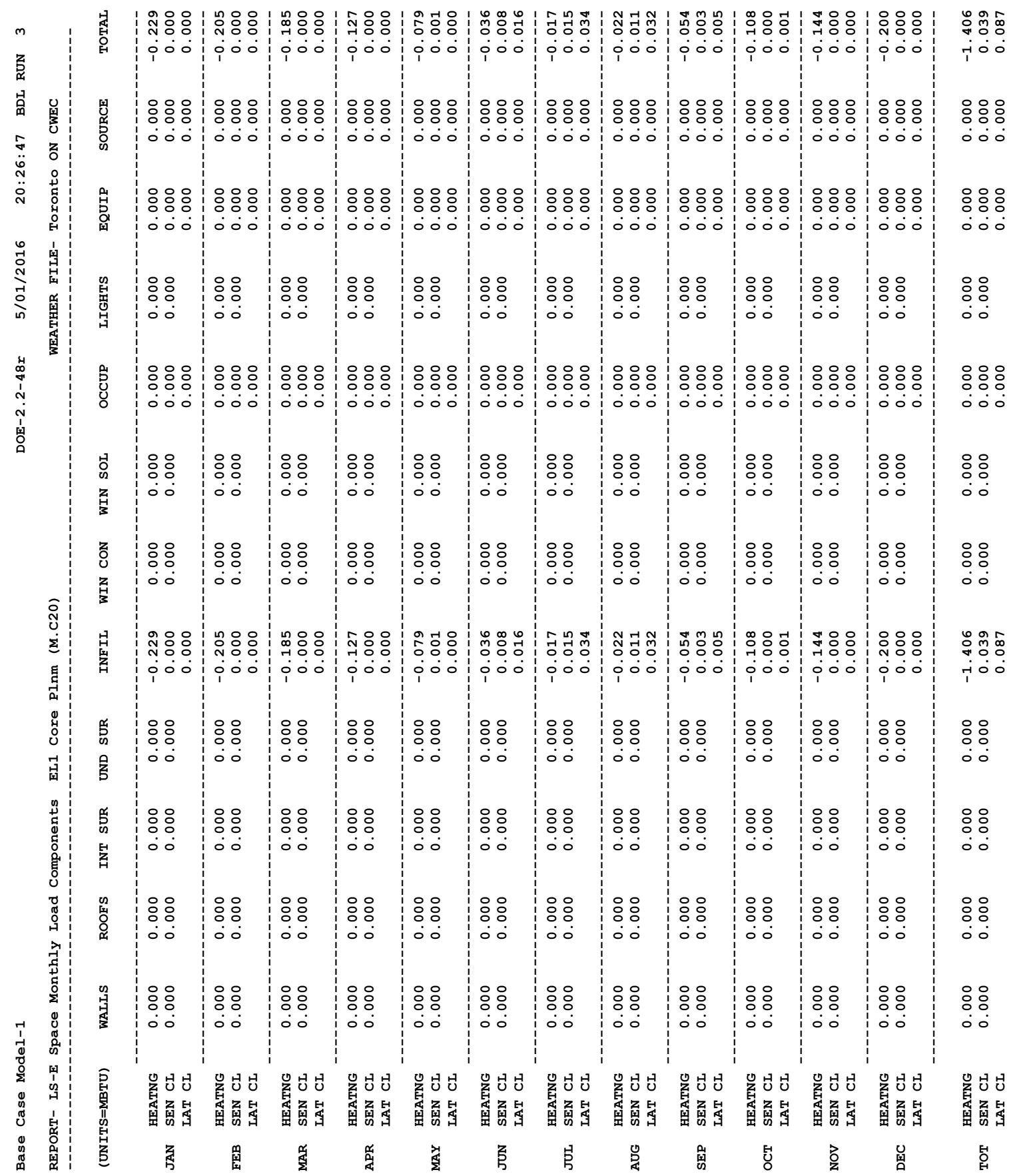




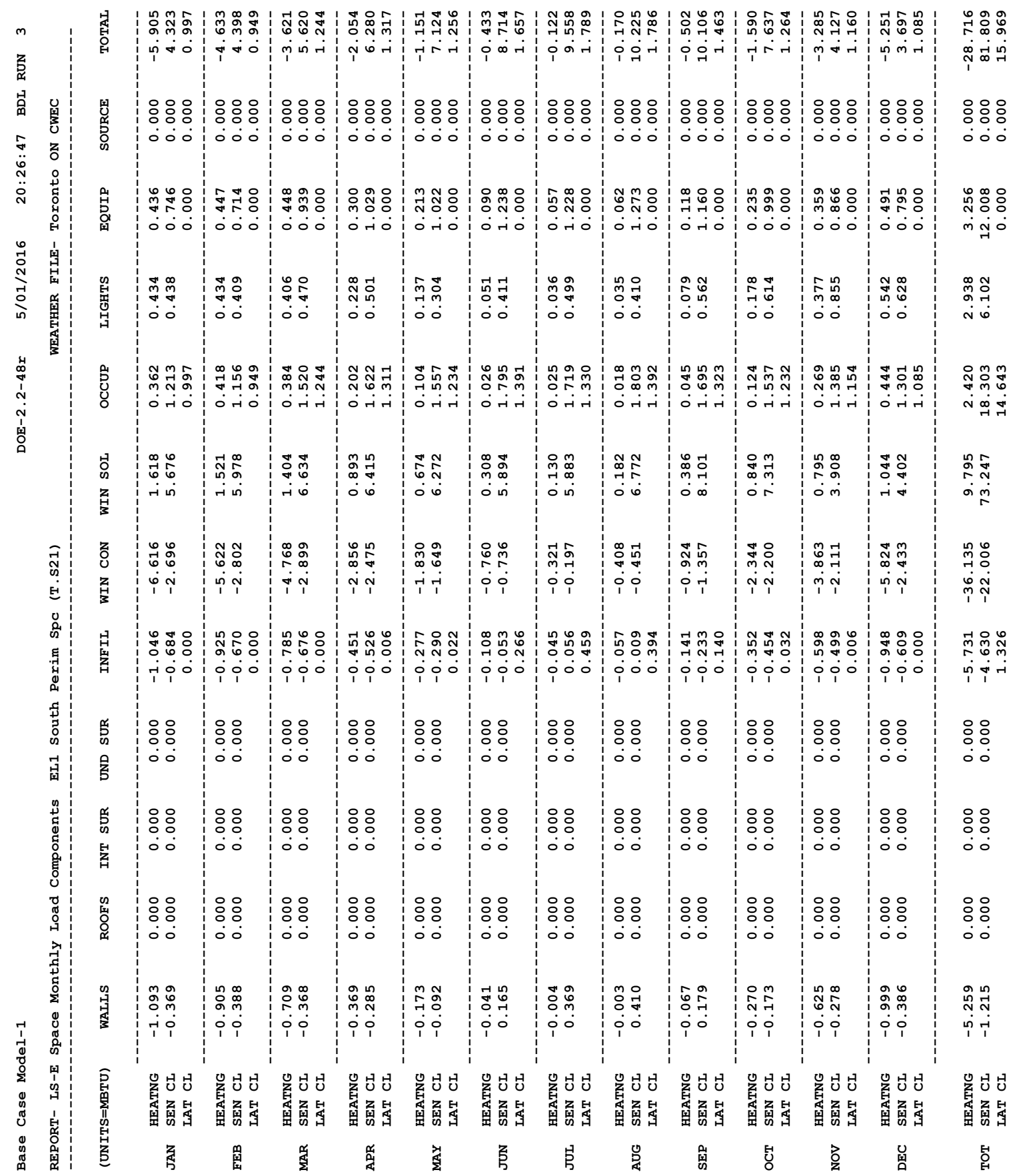




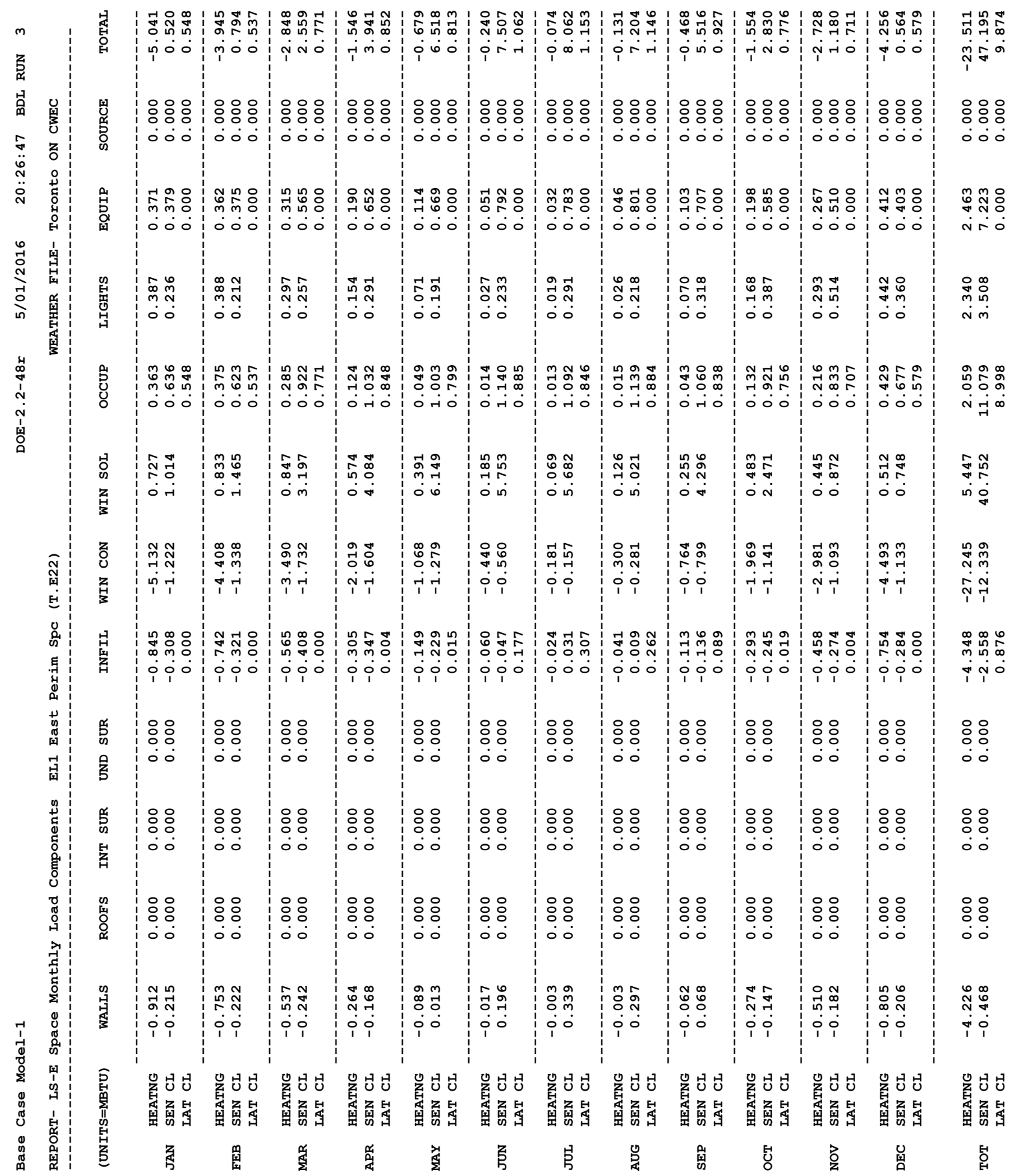




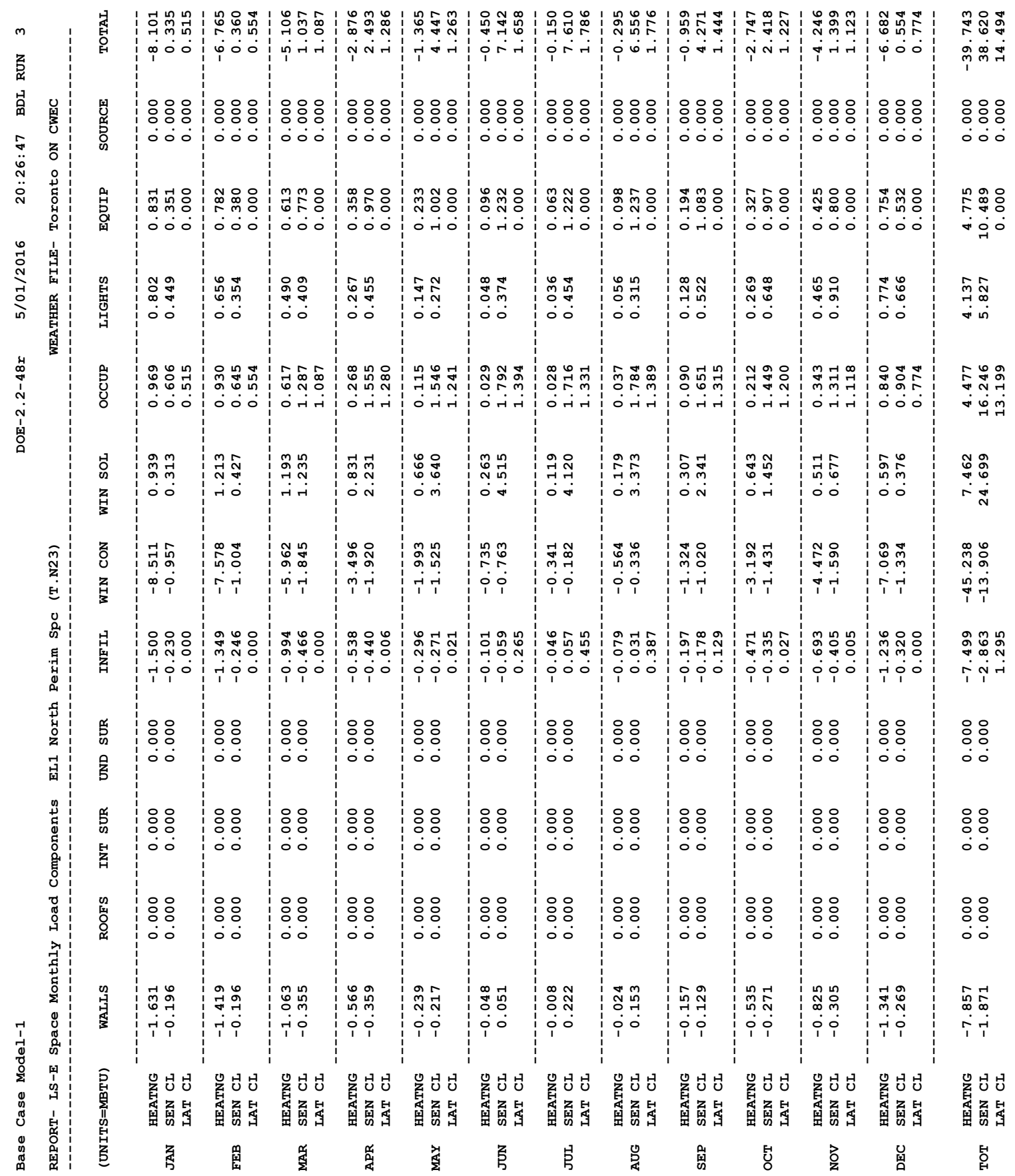




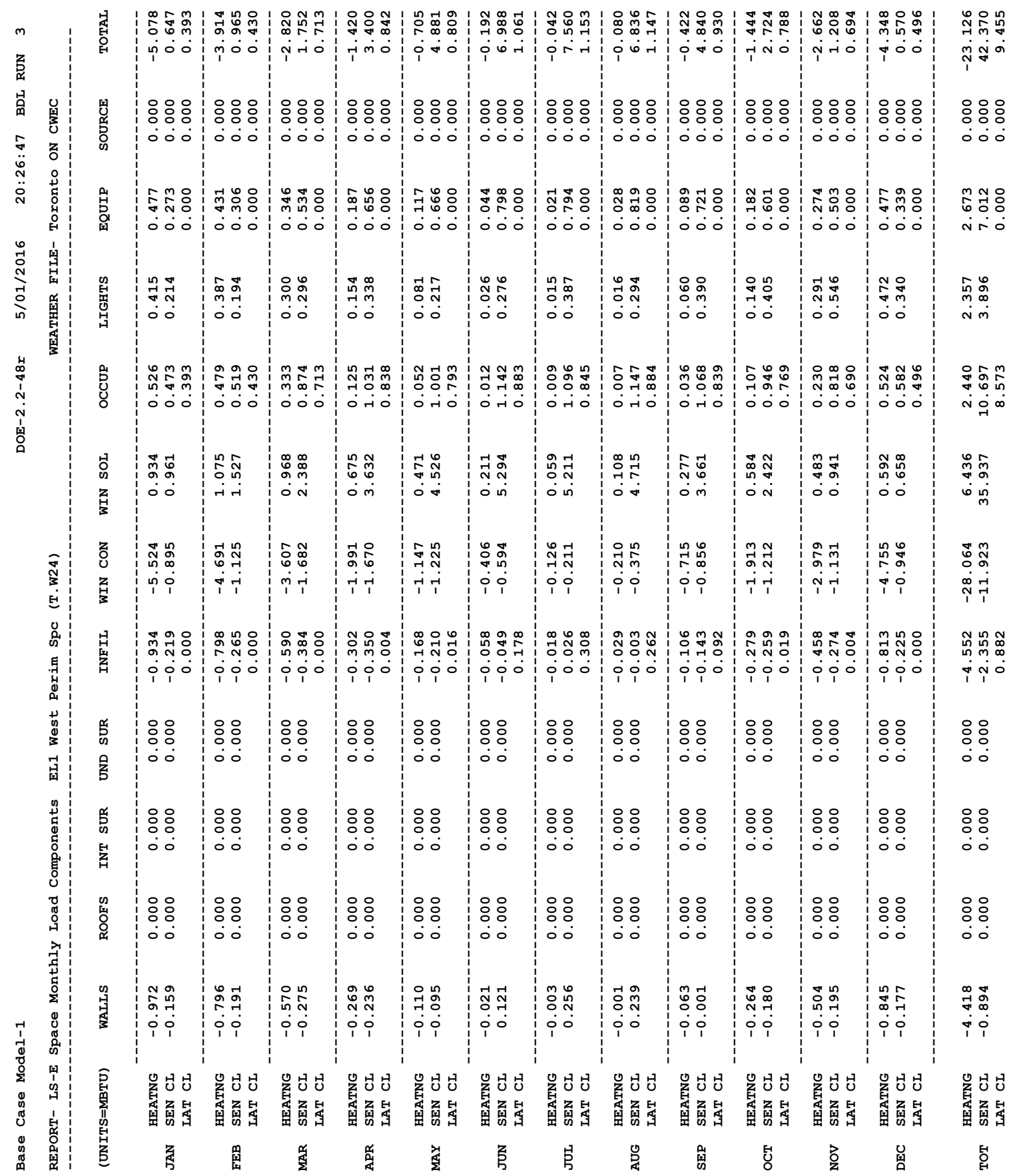




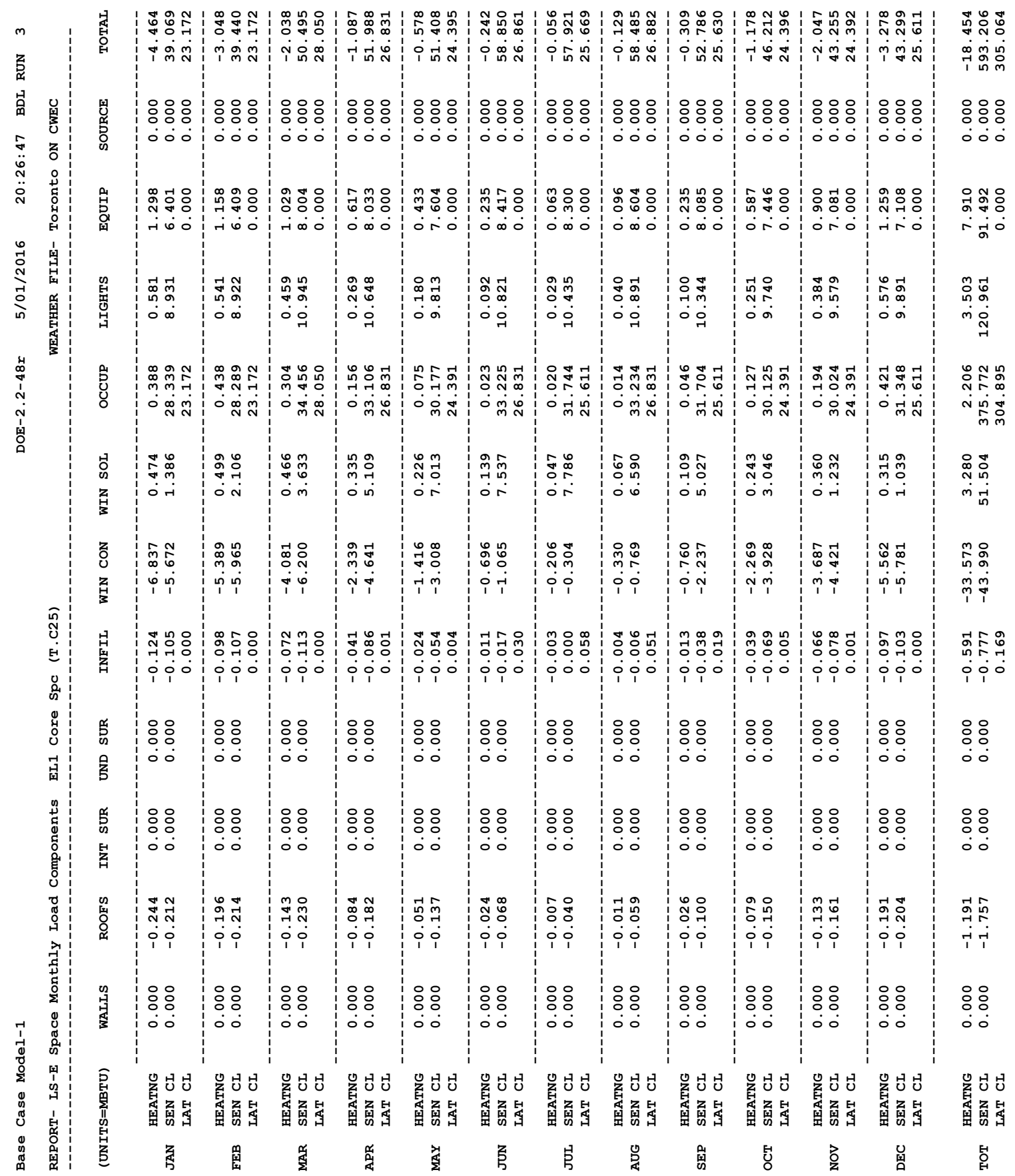




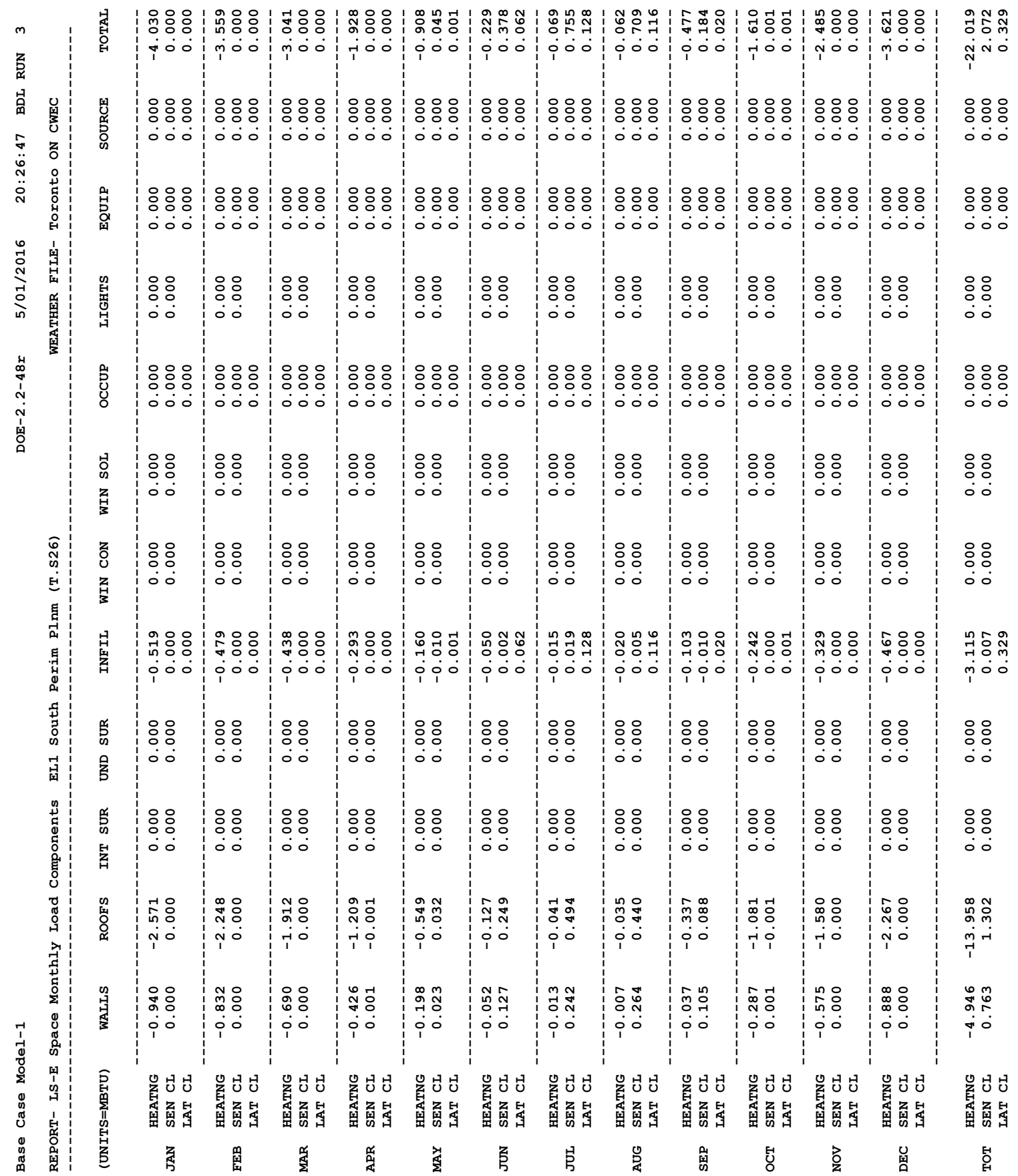




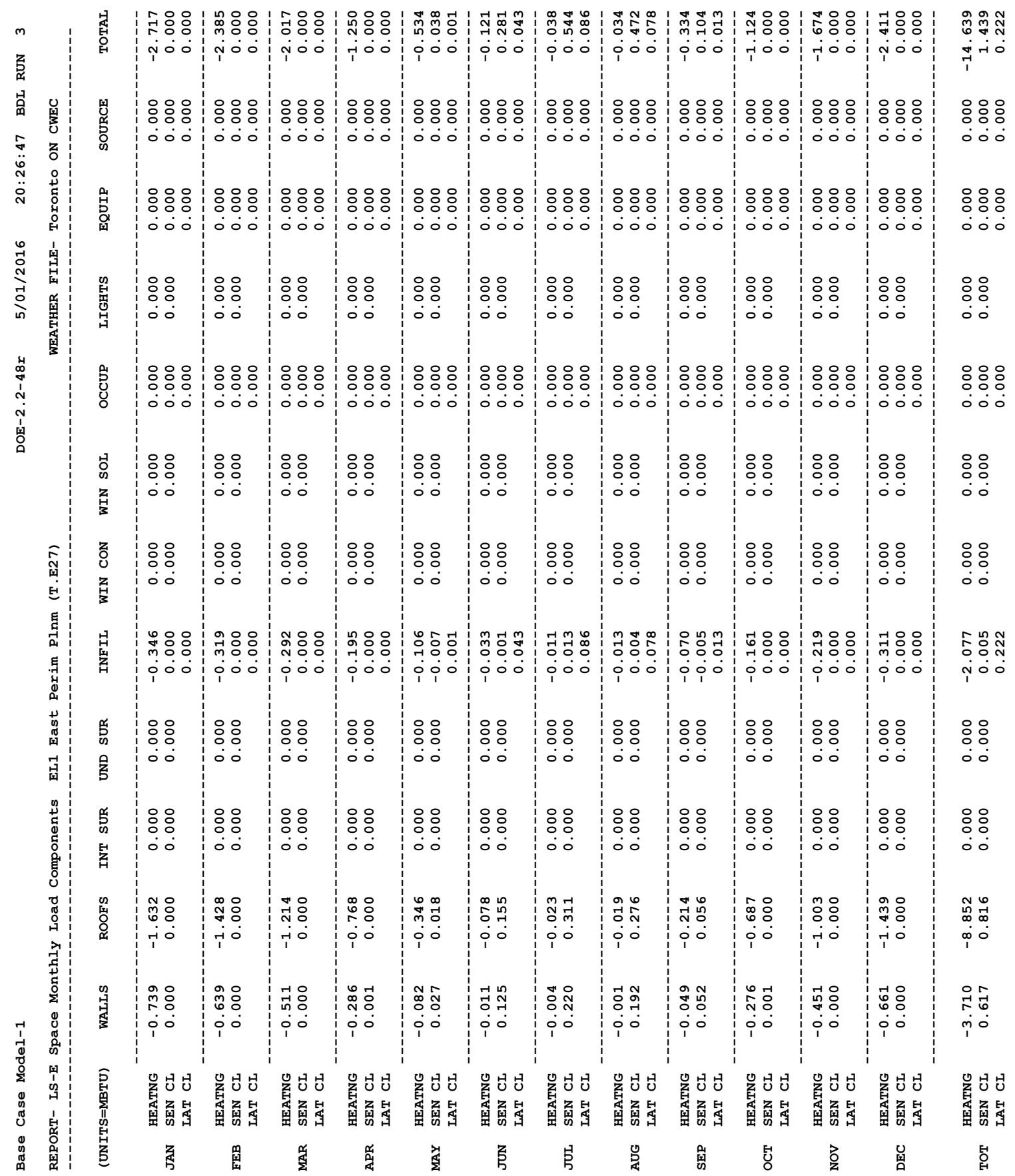




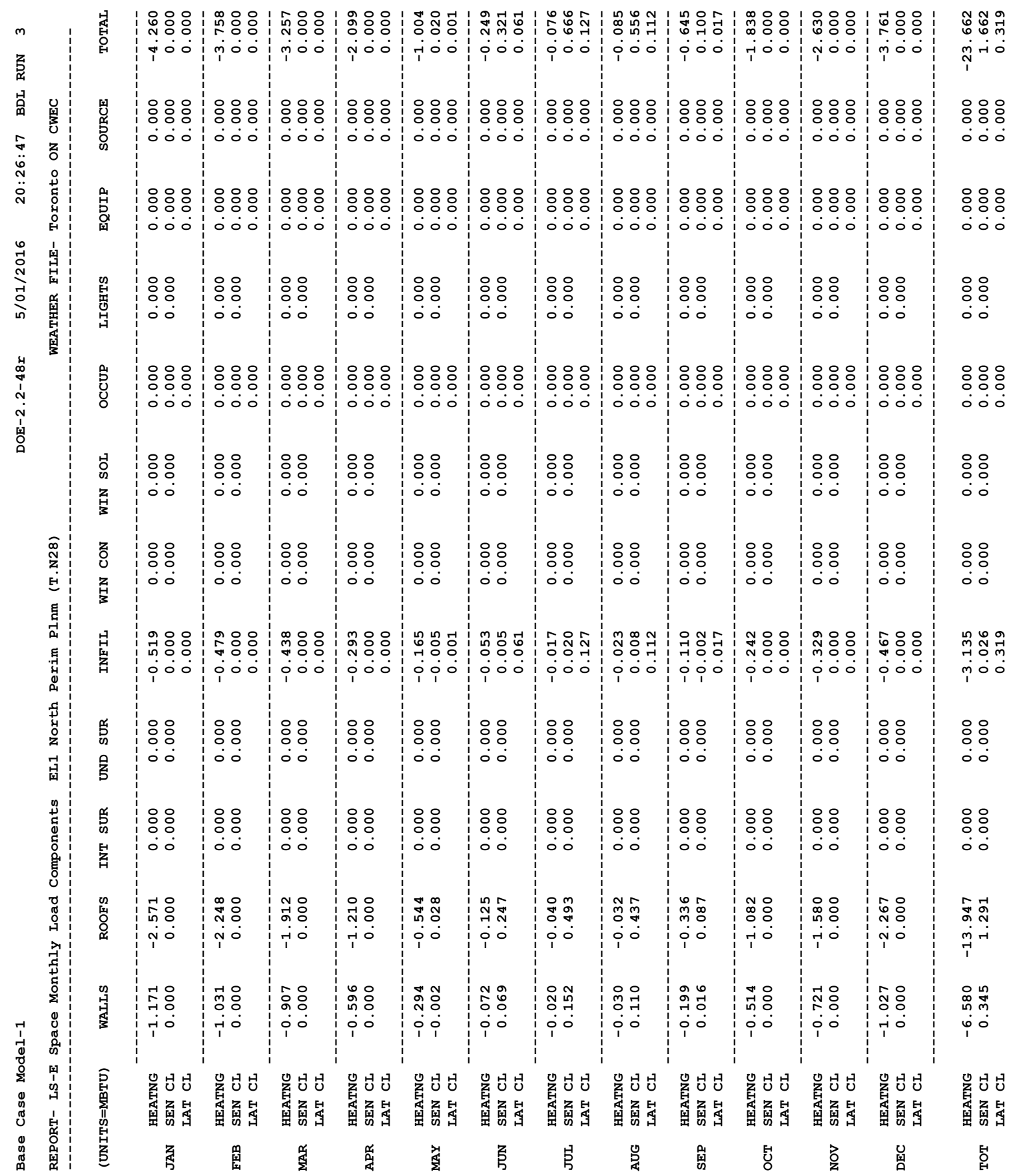




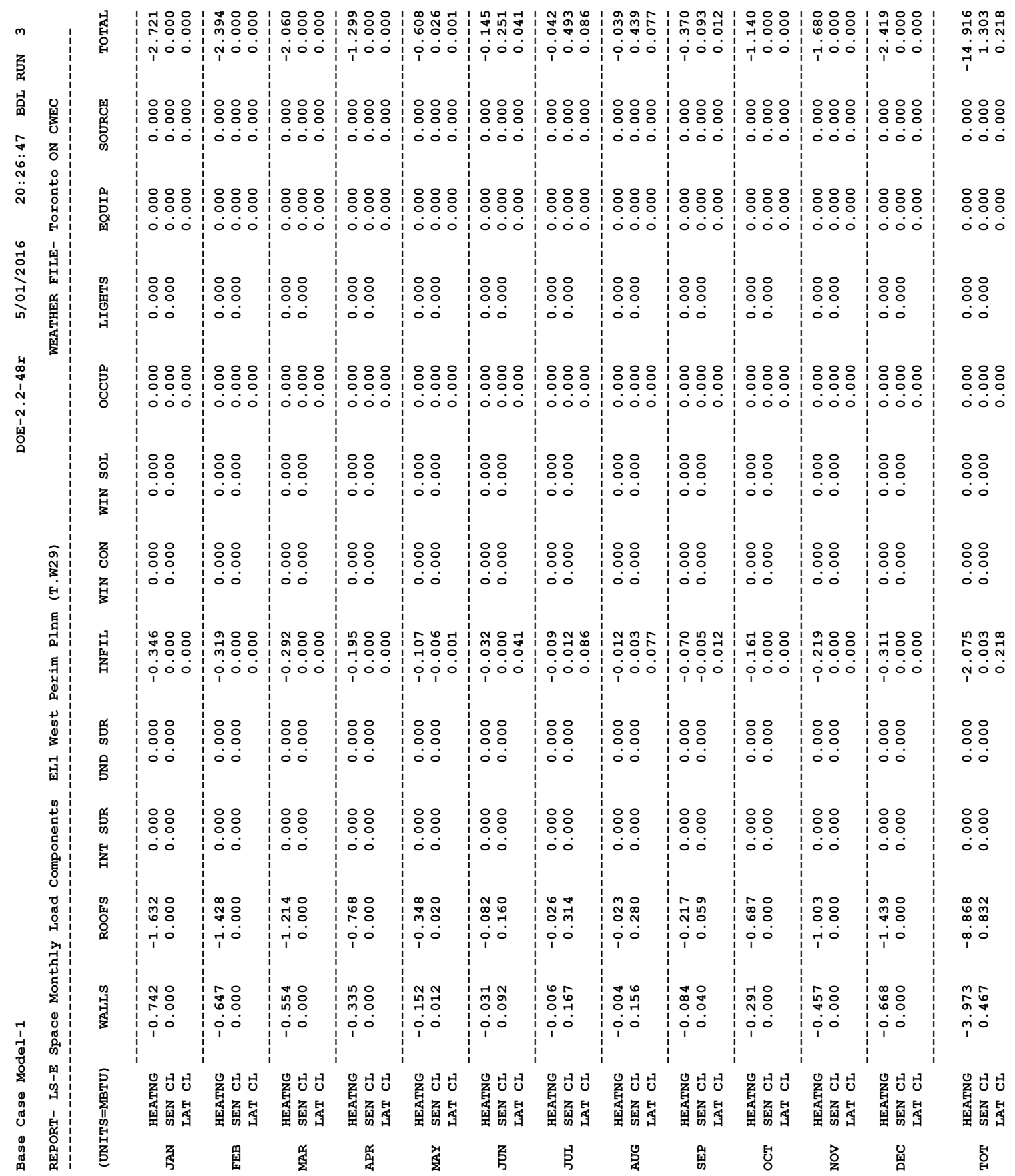




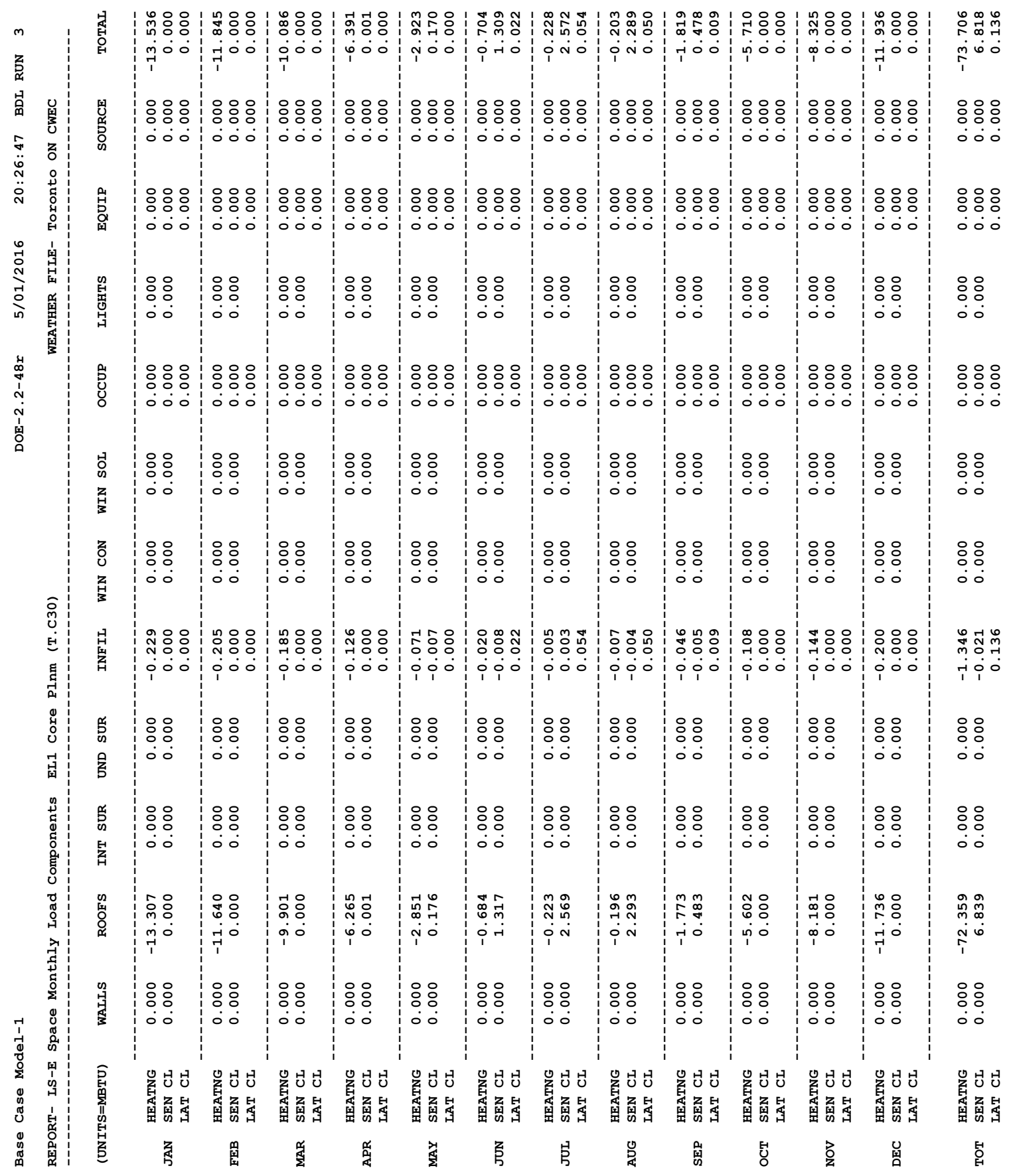




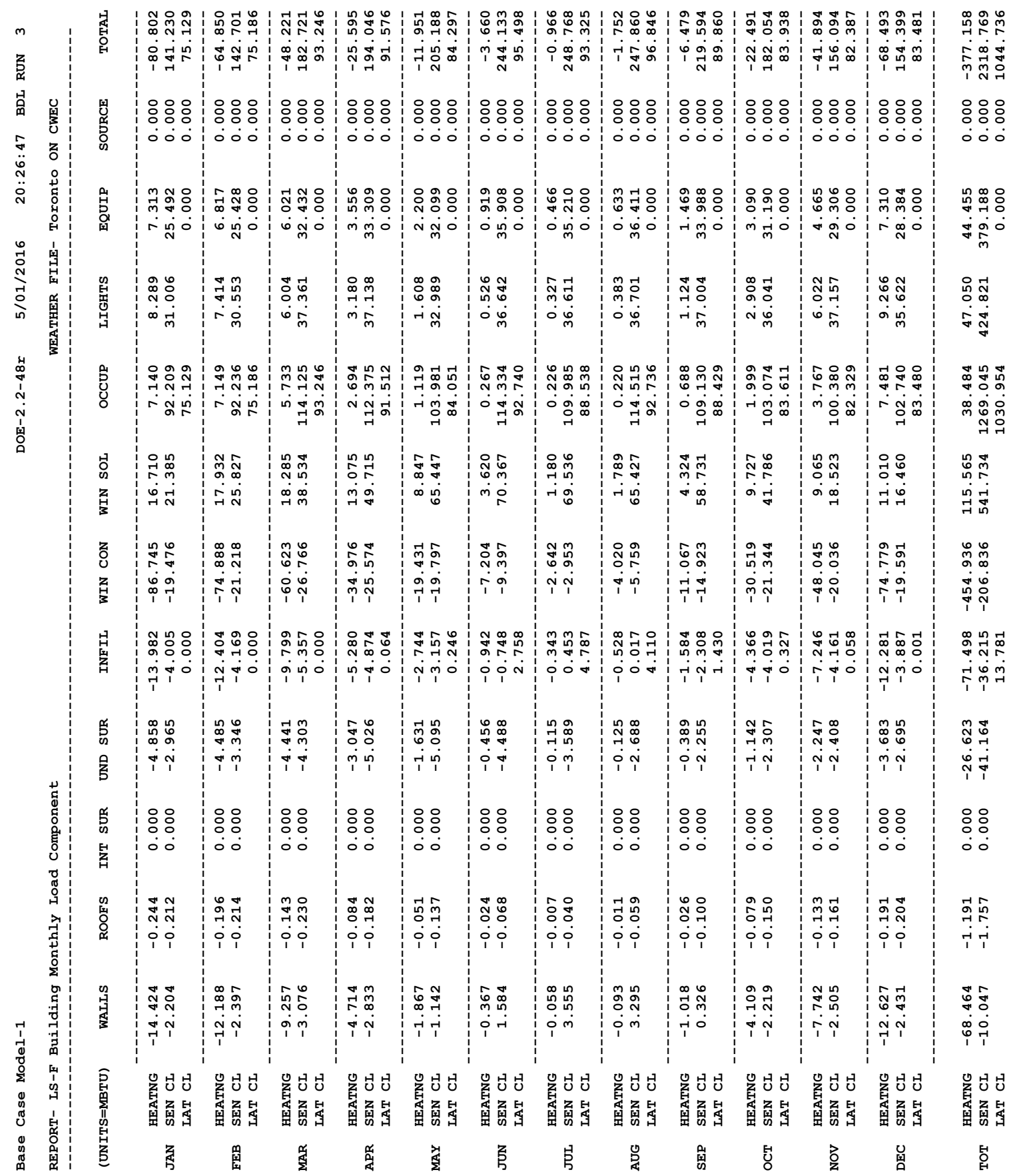




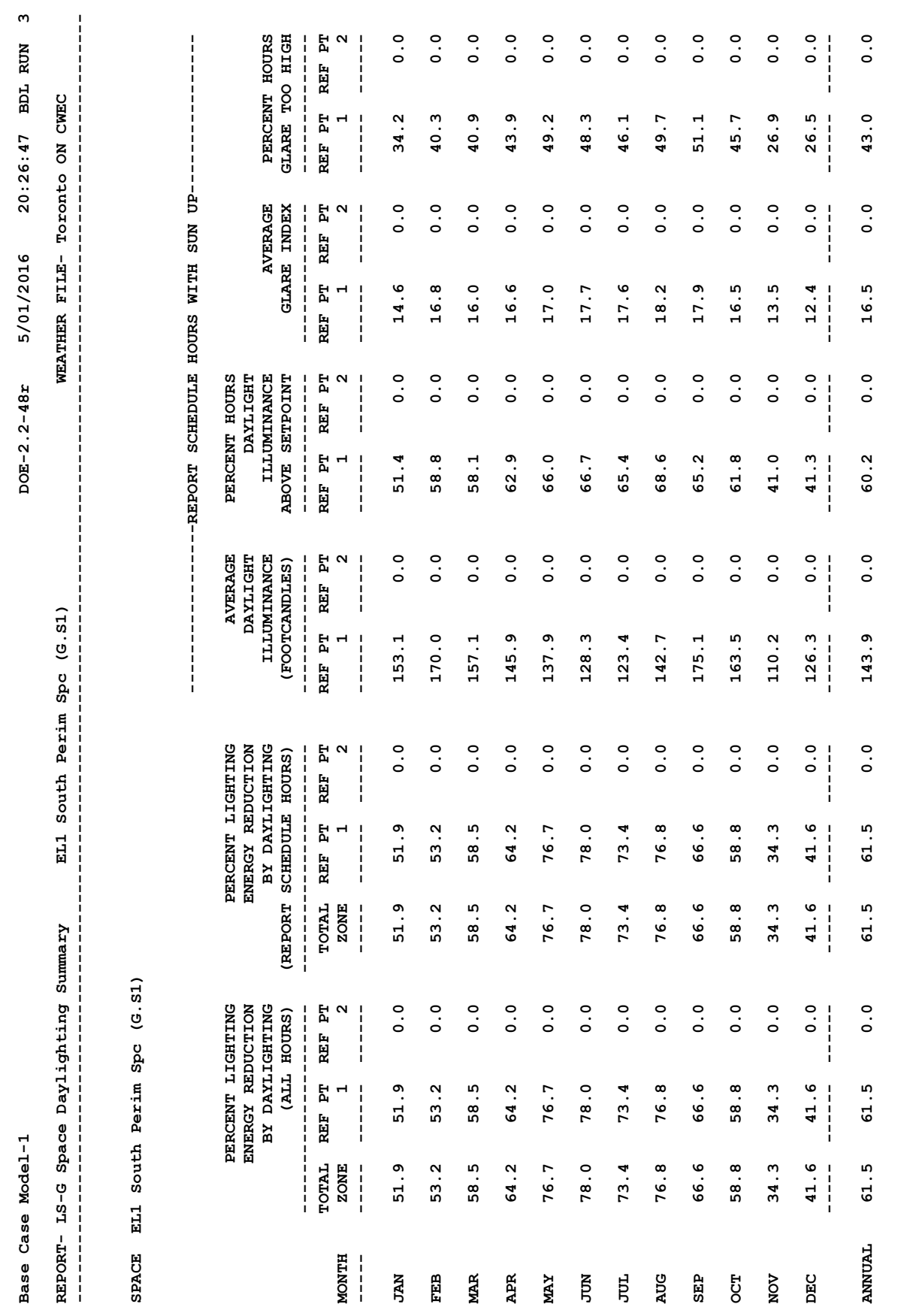




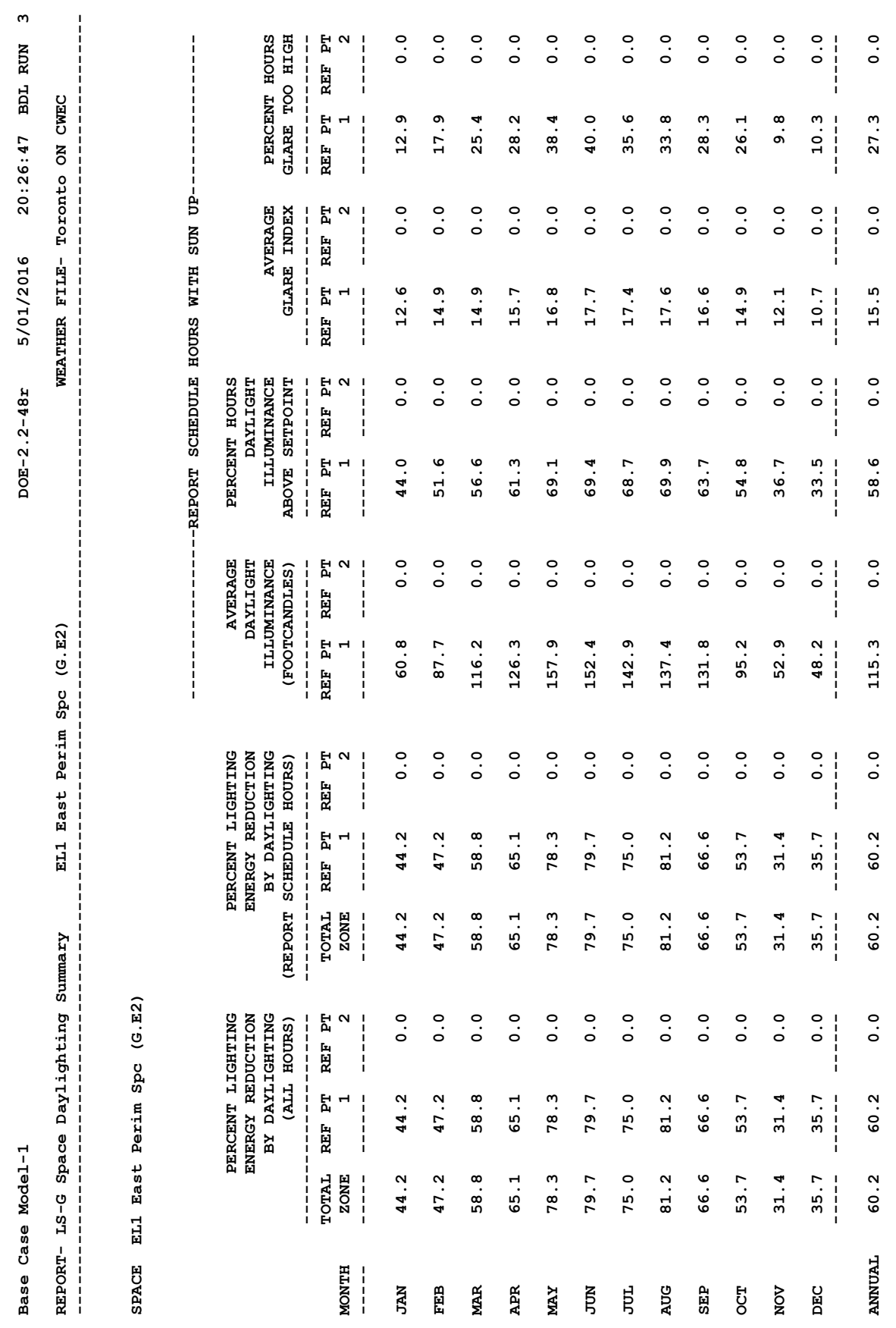




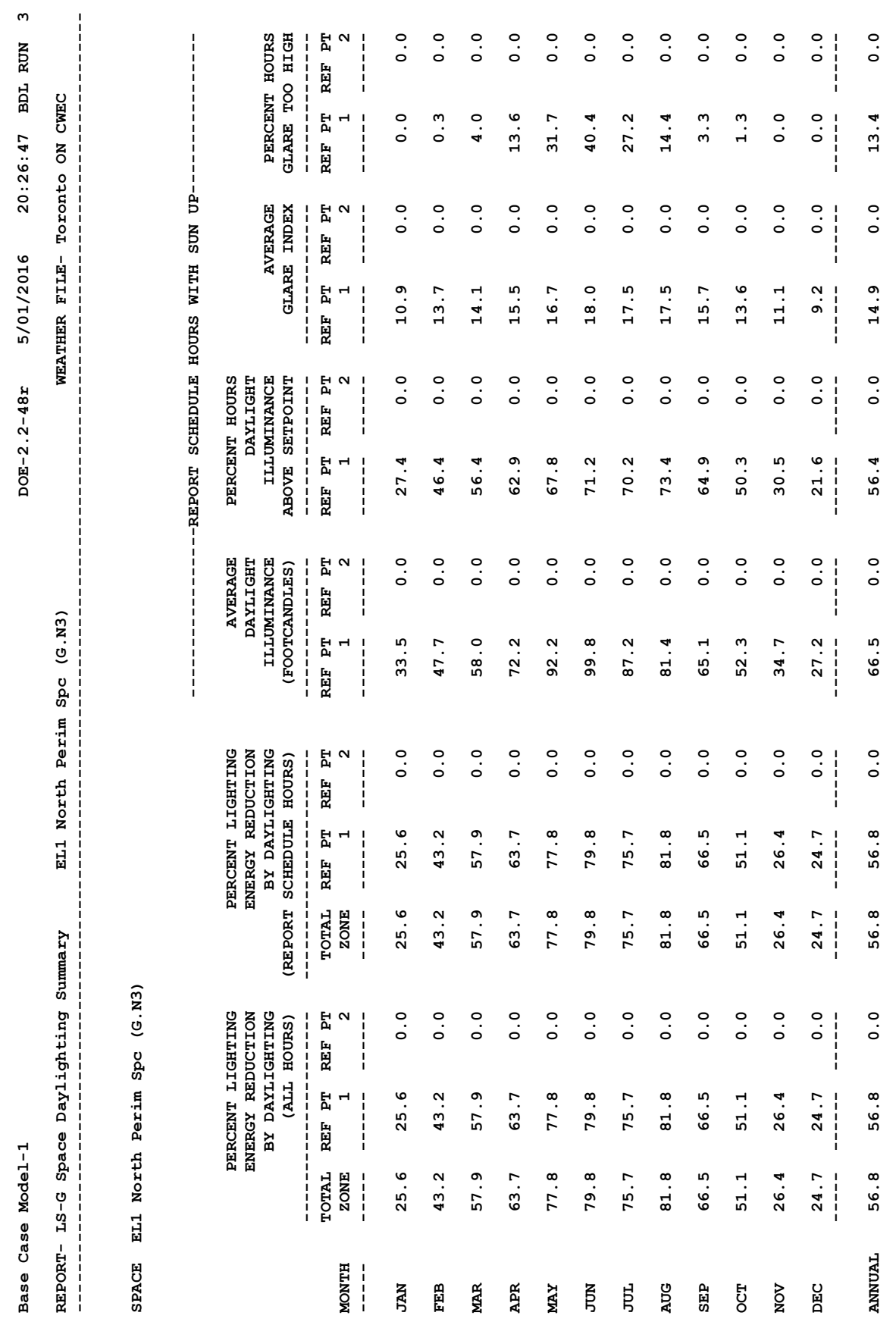




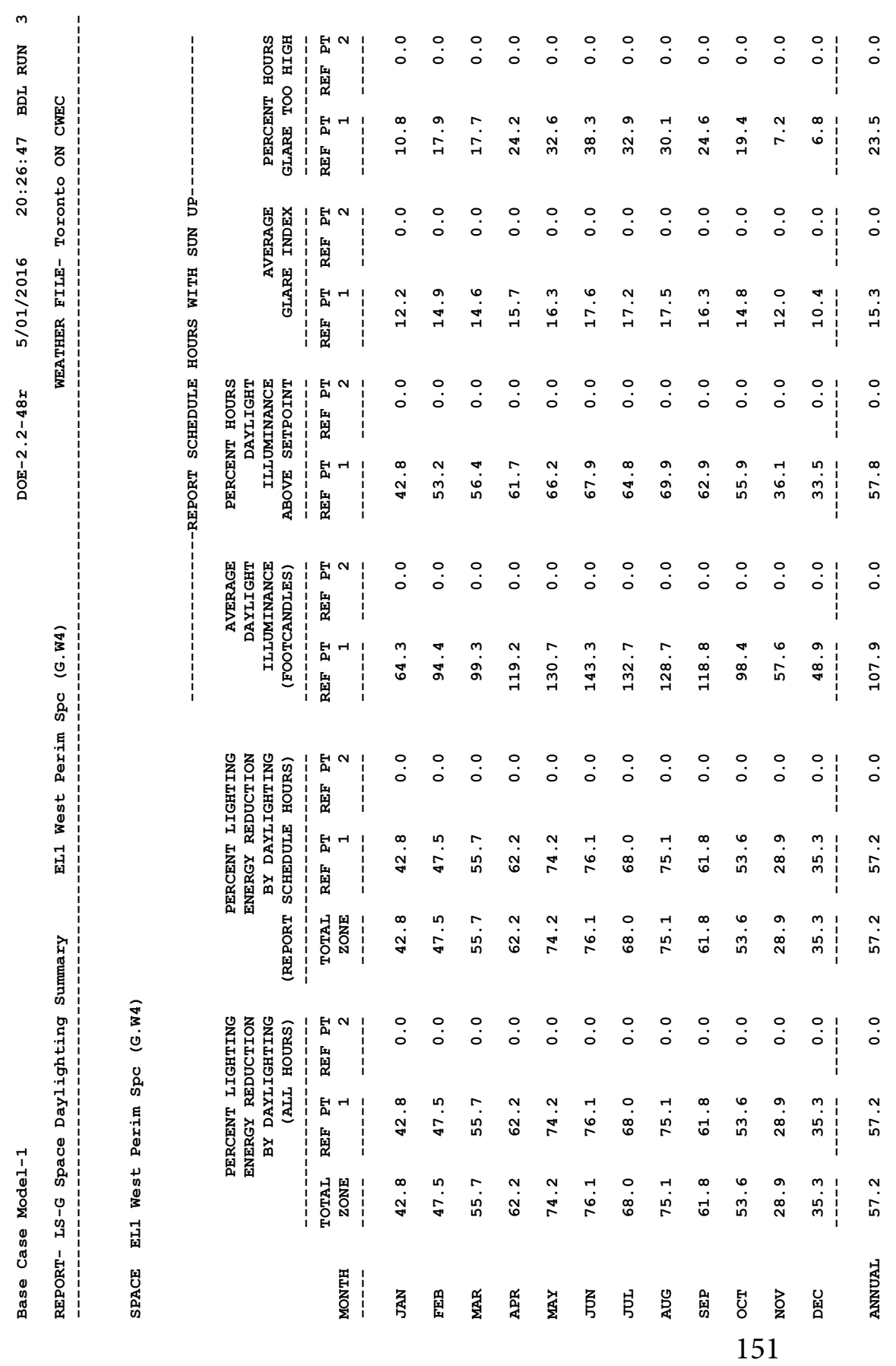




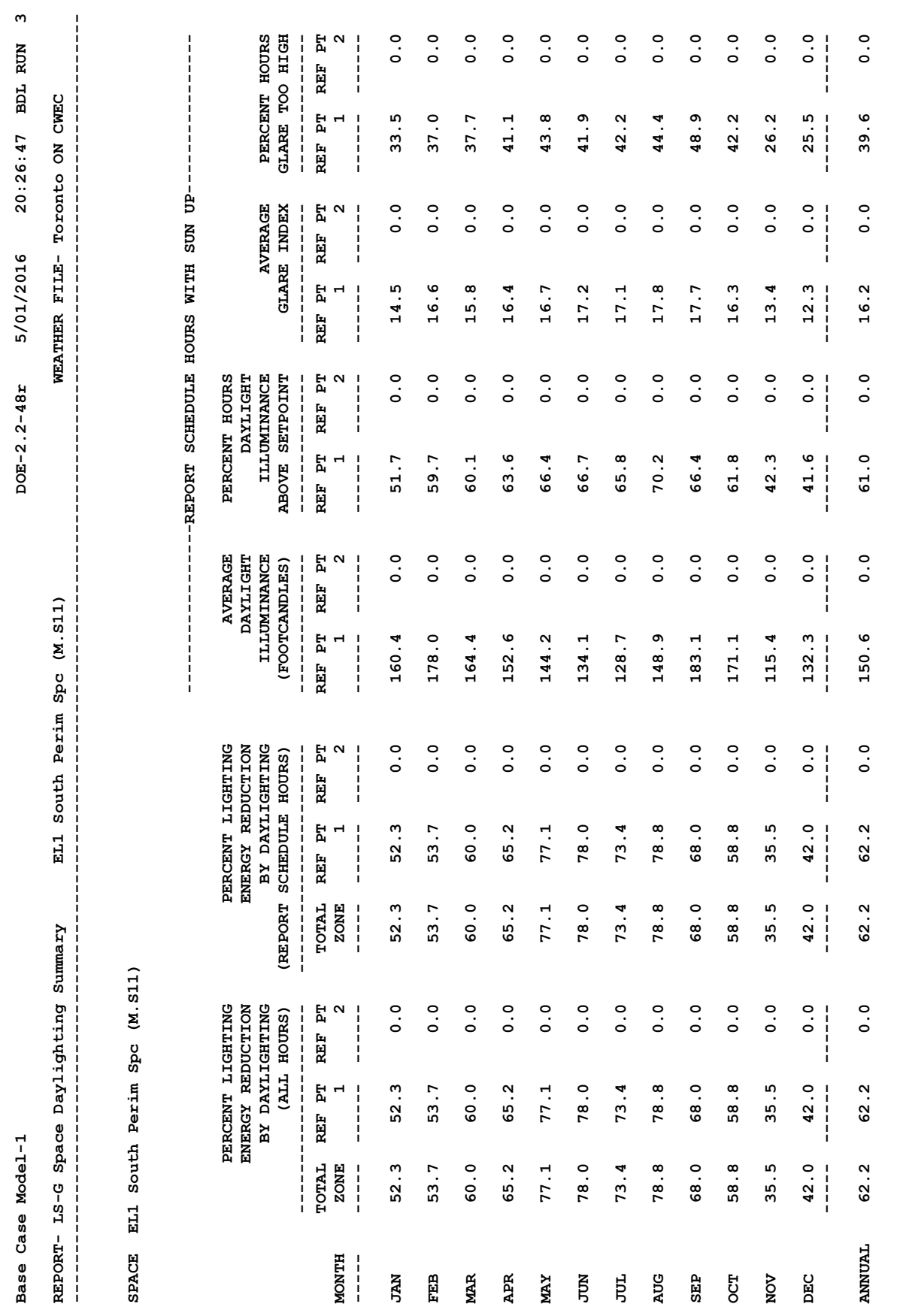




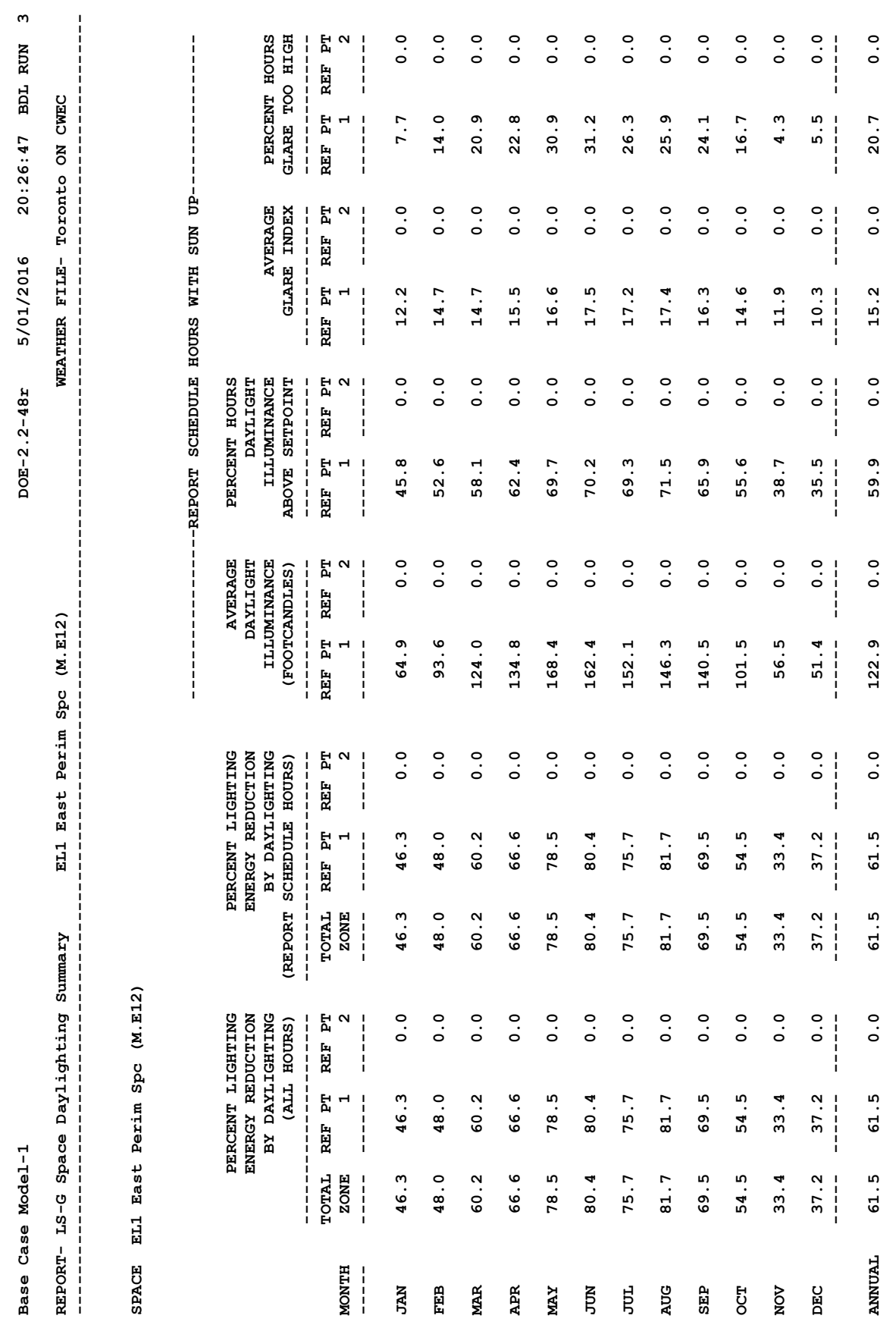




\section{References}

ASHRAE, “ASHRAE Handbook-Fundamentals", American Society of Heating, Refrigeration and Air-conditioning Engineering (ASHRAE), Atlanta, USA, 2005.

ASHRAE, “ANSI/ASHRAE/IESNA Standard 90.1, Energy Standard for Buildings Except Lowrise Residential Buildings" American Society of Heating, Refrigeration and Air Conditioning Engineers (ASHRAE), 2013.

ASHRAE, "Variable Refrigerant Flow Systems" ASHRAE Journal, April 2011.

ASHRAE, “ANSI/ASHRAE Standard 62.1-2007, Ventilation for Acceptable Indoor Air Quality" American Society of Heating, Refrigeration and Air Conditioning Engineers (ASHRAE), 2007.

City of Toronto, "Greenhouse Gases and Air Pollutants in the City of Toronto”, 2007.

Charneux, R., “Office Retrofit”, ASHRAE Journal, November 2010.

Clark, J., "Energy Simulation in Building Design", Second Edition, Butterworth Heinemann, UK, 2001.

CEA Technologies Inc, "Heat Pump Energy Efficiency Reference Guide”.

Climate Master, “Tranquility 30 Digital Series” Climate Master Water-source Heat Pumps, 2014.

Chwieduk, D., "Solar Energy in Building Thermal Balance for Efficient Heating and Cooling”, Elsevier Publication, 2014.

Duncan, P., “How High Can You Go?” ASHRAE Journal, September 2009.

Environment and Climate Change Canada, "GHG Emissions Quantification Guidance", 
Government of Canada, 2011.

Gordon, V., Holness, R., "Sustaining Our Future by Rebuilding Our Past", ASHRAE Journal, August 2009.

Hirsch, J., “eQuest Introductory Tutorial”, James J. Hirsch \& Associates, 2009.

Hootman, T., "Net Zero Energy Design - a guide for Commercial Architecture”, Jon Wiley \& Sons, 2013.

Lian, X., "Optimized Control Strategies for a Typical Water Loop Heat Pump System”, University of Nebraska-Lincoln, July 2011.

Liu, L., Qu, S., Ge, X., “Testing and Analysis of Thermal Performance for Water Source Heat Pump Systems”, University of Science and Technology Beijing, 2011.

Lussier, G., "Heat Recovery for Canadian Building”, ASHRAE Journal, December 2014.

McQuiston, Faye, C., "Heating, Ventilation and Air Conditioning Design \& Analysis" John Wiley \& Sons Inc. 1982.

McQuay Daikin International "McQuay Effinity Horizontal and Vertical Water Source Heat Pumps $-1 / 2$ to 5 tons".

McQuay Inc., “Water-source heat pump design manual”, 1999.

McKeen, P., Fung, A., "The Effect of Building Aspect Ratio on Energy Efficiency: A Case Study for Multi-Unit Residential Building in Canada”, Ryerson University, July 2014.

Nall, D., Crawley, D., "Energy Simulation in the Building Design Process". ASHRAE Journal, July 2011. 
NRCan, "Survey of Commercial and Institutional Energy Use-Buildings 2009". Natural Resource Canada, 2012.

NRCan, "Energy Efficiency-Buildings", Natural Resource Canada, 2014. Available online at http:/www.nrcan.gc.ca/energy/efficiency/buildings/4261

NRCan, “Energy Efficiency Trends in Canada, 1990 to 2009”, Office of Energy Efficiency, Ottawa, February 2011.

NRCan, "Internal Water-loop Heat Pumps-Commercial”, Office of Energy Efficiency, January 2016.

Shapiro, I., "Energy Audits in Large Commercial Office Buildings", ASHRAE Journal, January 2009.

Southard, L., Liu, X., Spitler, J., "Performance of HVAC Systems at ASHRAE HQ" ASHRAE Journal, September 2014.

Schneider Electric, "Leading Techniques for Energy Savings in Commercial Office Buildings" Schneider Electric, 2006.

Trane Inc., "Axiom Vertical/Horizontal: $1 / 2$ to 6 ton Water Source Heat Pumps", Trane Inc., 2013.

Rao, G., Sauer, H., "Energy Conservation Using the Closed Water Loop Heat Pump”, Missouri Academy of Science, 2002.

Zheng, G., Jing, Y., “Thermodynamic Performance Analysis of Water Source Heat Pump in Variant Operating Condition", North China Electric Power University, 2009. 